\title{
Experiments to improve the quality of sex-sorted fresh and frozen porcine spermatozoa
}

\author{
Dissertation \\ to obtain the $\mathrm{Ph}$. D. degree \\ in the International Ph. D. Program for Agricultural Sciences in Göttingen (IPAG) \\ at the Faculty of Agricultural Sciences, \\ Georg-August-University Göttingen, Germany
}

\author{
presented by \\ Rudolf Großfeld \\ born in Marl
}

Göttingen, May 2007 
D7

1. Name of supervisor: Prof. Dr. W. Holtz

2. Name of co-supervisor: Prof. Dr. D. Rath

Date of dissertation: 24. May 2007 
Man muß viel gelernt haben, um über das, was man nicht weiß, fragen zu können. Jean-Jacques Rousseau

28.06.1712 - 02.07.1778 
Table of Contents

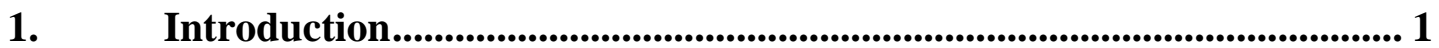

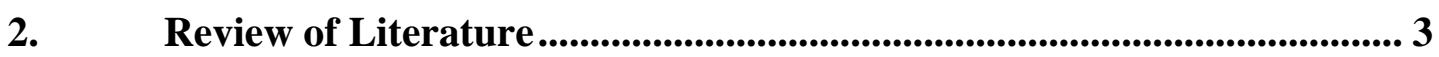

2.1 Spermatozoa ..................................................................................................... 3

2.1.1 Morphology and Motility.............................................................. 3

2.1.2 Biochemistry of membranes ....................................................... 5

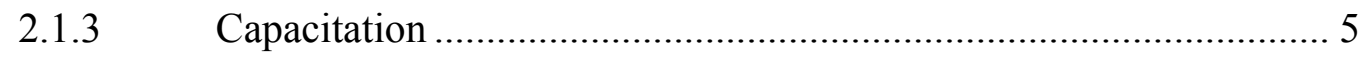

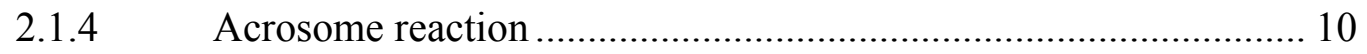

2.2 Cryo-preservation methods for boar spermatozoa.............................. 11

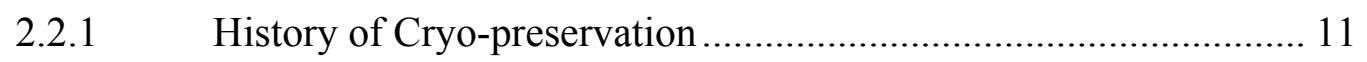

2.2.2 Development of cryo-preservation methods for boar semen.......... 13

2.3 Strains for boar spermatozoa during cryopreservation......................... 45

2.3.1 Effect of cryopreservation on sperm cell organelles ..................... 45

2.3.2 Significance of reactive oxygen species (ROS) ........................... 49

2.3.3 Tests to evaluate sperm functionality ......................................... 56

2.4 Gender preselection in animal breeding .................................................... 65

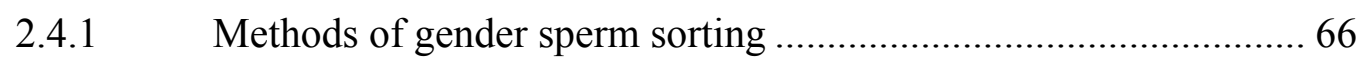

2.4.2 Beltsville Sperm Sexing Technology ........................................... 66

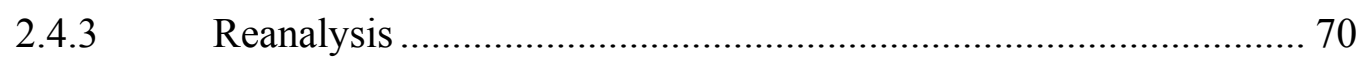

2.4.4 Influence of flow cytometry on spermatozoa .............................. 70

2.4.5 Cryopreservation of flow cytometrical sorted spermatozoa ........... 72

2.5 Conclusions of the review of the current literature ............................. 73

3. CHAPTER 1: Quality assessment of frozen/thawed boar semen against individual freezing curves in the presence of antioxidants...... 74

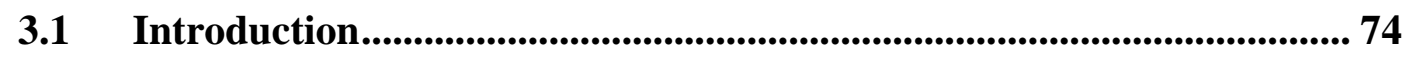

$3.2 \quad$ Material and methods........................................................................................ 75

3.2.1 Freezing of boar semen in the presence of ROS scavengers ......... 75

3.2.2 Freezing of boar semen following different freezing curves.......... 78

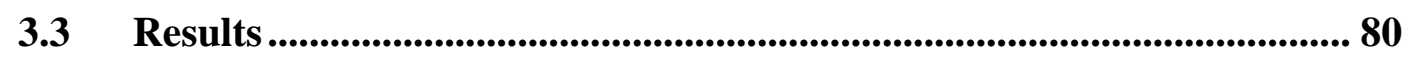

3.3.1 Freezing of boar semen in the presence of ROS scavengers ......... 80

3.3.2 Quality assessment of frozen/thawed boar semen against individual freezing speeds ..................................................... 82 


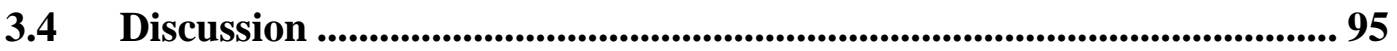

4. CHAPTER 2: Improvement of sex-sorted fresh and frozen-thawed boar spermatozoa and their subsequent insemination efficiency after supplementation of the extender with antioxidants ..................... 98

4.1 Introduction................................................................................... 98

4.2 Material and Methods ............................................................................99

4.2.1 Experiment 1: Improvement of sex sorted fresh boar spermatozoa using Androhep ${ }^{\mathrm{TM}}$ supplemented with different antioxidants.

4.2.2 Experiment 2: Improvement of sex sorted frozen boar spermatozoa using cooling and freezing media supplemented with different antioxidants

4.2.3 Experiment 3: Tubal insemination of sex-sorted frozen/thawed

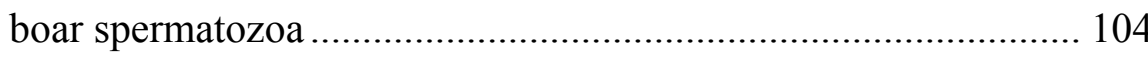

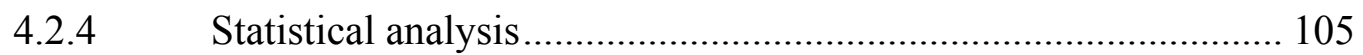

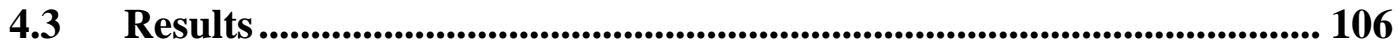

4.3.1 Experiment 1: Improvement of sex sorted fresh boar spermatozoa using Androhep ${ }^{\mathrm{TM}}$ supplemented with different

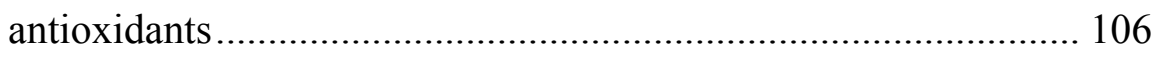

4.3.2 Experiment 2: Improvement of sex sorted frozen boar spermatozoa using cooling and freezing media supplemented with different antioxidants

4.3.3 Experiment 3: Tubal insemination of sex-sorted frozen/thawed boar spermatozoa ................................................................... 113

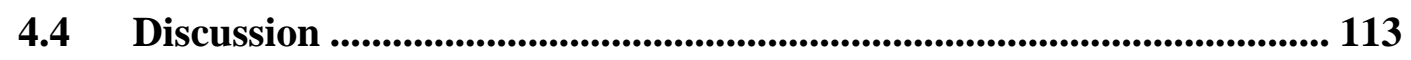

5. General discussion and conclusions .............................................. 117

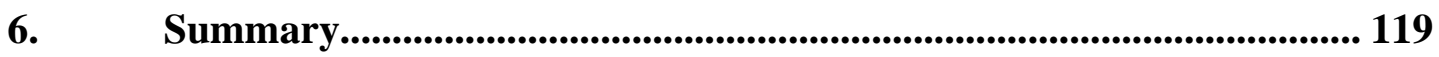

7. Zusammenfassung …...................................................................................... 123

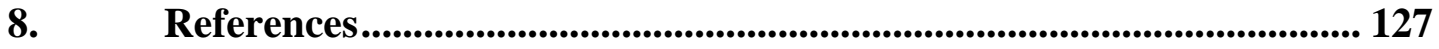

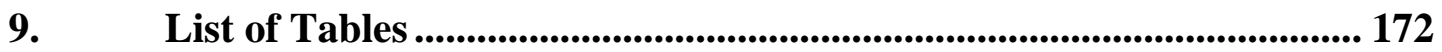

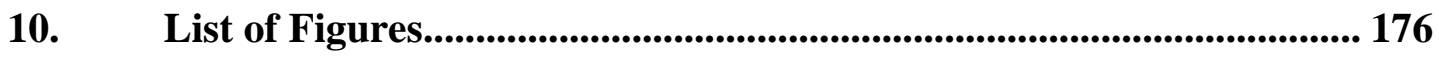




\section{List of Abbreviations}

$\mu 1 \quad$ micro litre

$\mu \mathrm{m} \quad$ micrometer

AI artificial insemination

AO antioxidants

ATP adenosine triphosphate

BSA bovine serum albumin

BSST Beltsville Sperm Sexing Technology

cAMP cyclic adenosine mono-phosphate

${ }^{\circ} \mathrm{C} \quad$ degrees Celsius

$\mathrm{Ca} \quad$ Calcium

$\mathrm{cm} \quad$ centimetre

DUI deep intrauterine insemination

ET embryo transfer

et al. et alii

FISH fluorescence in situ hybridisation

FITC-PNA fluorescein isothiocyanate labelled peanut agglutinin from

Arachis hypogaea

FSH follicle stimulating hormone

$\mathrm{F} / \mathrm{T} \quad$ frozen/thawed

g gravity

g gram

h hour

hCG human chorionic gonadotropin

ICSI intracytoplasmatic sperm injection

IUI intrauterine insemination

IVF in vitro fertilisation

$\mathrm{kHz} \quad$ Kilohertz

LH luteinising hormone

$\mathrm{LN}_{2} \quad$ liquid nitrogen

mg milligram

min. minute 


$\begin{array}{ll}\text { mm } & \text { millimetre } \\ \text { mMol } & \text { milliMol } \\ \text { n.s. } & \text { not significant } \\ \text { p } & \text { significance level } \\ \text { PBS } & \text { phosphate buffered saline } \\ \text { PCR } & \text { polymerase chain reaction } \\ \text { pH } & \text { pondus hydro genii } \\ \text { PI } & \text { propidium iodide } \\ \text { PMSG } & \text { pregnant mare's serum gonadotropins } \\ \text { ROS } & \text { reactive oxygen species } \\ \text { SD } & \text { standard deviation } \\ \text { TALP } & \text { Tyrode, Albumin, Lactate, Pyruvat } \\ \text { UTJ } & \text { utero-tubal junction } \\ \text { UV } & \text { ultraviolet } \\ \leq & \text { less or equal as } \\ \times & \text { Mean value }\end{array}$




\section{Introduction}

Cryo-preserved boar sperm has been available for commercial purposes since 1975 (Westendorf et al. 1975, Johnson 1985). However, even though it is used in some commercial production occasions (Hofmo and Grevle 2000), for example in genetic transfer projects, frozen boar semen cannot be used under production conditions as efficiently as liquid-preserved semen. Reasons are the high susceptibility of boar spermatozoa to damage during cryo-preservation and a complicated process of deep freezing. Even though new trends like microinjection of dry frozen or dry fixed spermatozoa or culture and transplantation of spermatogonial stem cells are objective of research programmes, the liquid and cryo-conservation of spermatozoa remain as only choice for storage and commercial use of porcine semen (Yoshida 2000).

Weitze (2000) estimated that annually worldwide 155 million sperm dosages are produced for artificial insemination. From these $99 \%$ are preserved in a liquid form (Wagner and Thibier 2000). Liquid preservation ensures a storage time of about 3-5 with a maximum of 7 days (Weitze 2000). For international sperm exchange, cryoconservation is a prerequisite. During storage in liquid nitrogen cell metabolism is almost completely inhibited. The only strain to cryo-preserved cells is the terrestrial background radiation and the half-life period of surviving spermatozoa is estimated to about 2000-4000 years (Mazur 1985).

Cryo-preservation is a prerequisite if specially treated or selected spermatozoa need to be stored. This is mainly the case when the capabilities for their production is limited as for example for gender preselection employing flow cytometry.

The only proven method to affect the gender of offspring is the flow cytometrical separation of X-and Y-bearing spermatozoa (Johnson et al. 2005a). With the latest generation of flow cytometers about 15 million spermatozoa can be produced per hour and sex. For non-surgical insemination of sexed spermatozoa a sperm dosage of at least $50 \times 10^{6}$ is required (Rath et al. 2003a, Grossfeld et al. 2005). As the life span of sorted fresh spermatozoa is lower than for unsorted equivalents, insemination has to be timed precisely and spermatozoa have to be inseminated close to ovulation. To setup efficient AI-logistics, freezing of sex sorted spermatozoa would be very advantageous if the post thaw quality would be acceptable. 
Therefore the ultimate goal of the present study was to adapted existing freezing methods for porcine spermatozoa to the conditions of flow cytometrically sex sorted spermatozoa. 


\section{2. $\quad$ Review of Literature}

\section{$2.1 \quad$ Spermatozoa}

The male germ cell contains a haploid set of chromosomes. The cell fuses with the also haploid female germ cell, the oocyte, to build up the diploid zygote and to start the development of new life.

The sperm cell is able to fulfil a lot of functions in order to complete this task. The morphology of spermatozoa and their interaction with the varying environment in the female genital tract are of great significance (Fraser and Ahuja 1988).

\subsubsection{Morphology and Motility}

The sperm cell basically consists of head and tail. The latter is composed of the neck, mid, principal, and end piece.

The main part of the sperm head is the haploid nucleus, consisting of highly condensed chromatin (Wehner and Gehring 1990). Two third of the sperm head is covered with the acrosomal cap, which contains the necessary enzymes to penetrate the corona radiata and zona pellucida, i.e. hyaluronidase, acrosine and others (Leonhardt 1990). Acrosine has both proteolytic and binding characteristics (TöpferPetersen and Schill 1989).

The tail allows the sperm cell to actively penetrate the oocyte. The neck or connecting piece forms a basal plate that fits into depression in the posterior aspect of the nucleus. The basal plate of the neck continuous posterior throughout the most of the tail. The region to the tail between the neck and the annulus is the midpiece. The central core of the mid piece together with the entire length of the tail, comprises the axoneme. The axoneme itself is composed of nine pairs of microtubules that are located radial around two central filaments. In the middle this 9+2 arrangement of microtubules is surrounded by nine outer coarse of dense fibres that appear to be associated with the nine doublets of the axoneme. The axoneme and associated dense fibres of the mid piece are covered peripheral by numerous mitochondria. The 
mitochondria are arranged in a helical pattern around the longitudinal fibres of the tail (Garner and Hafez 2000). The mitochondria provide energy by delivering ATP.

The principal piece, which continues posterior from the annulus extends to near the end of the tail, is composed centrally of the axoneme and its associated coarse fibres. A fibrous sheath provides stability for the contractile elements of the tail.

The end piece, which is posterior to the termination of the fibrous sheath, only contains the central axoneme covered by the plasma membrane. The axoneme is responsible for sperm motility. By cleaving ATP with dynein and kinesin molecules the outer pairs of microtubules of the $9+2$ patterns generate the bending waves of the tail by a sliding movement between adjacent pairs (Lehninger et al. 1994).

The spermatozoa gain their capability of tail movement during their maturation in the epididymis. Mohri and Yanagimachi (1980) showed that hamster spermatozoa, recovered from the testicles and head of epididymis, were immotile. But spermatozoa recovered from the tail of the epididymis and ejaculated spermatozoa were motile.

Figure 1: $\quad$ Spermatozoa (Garner and Hafez 2000)

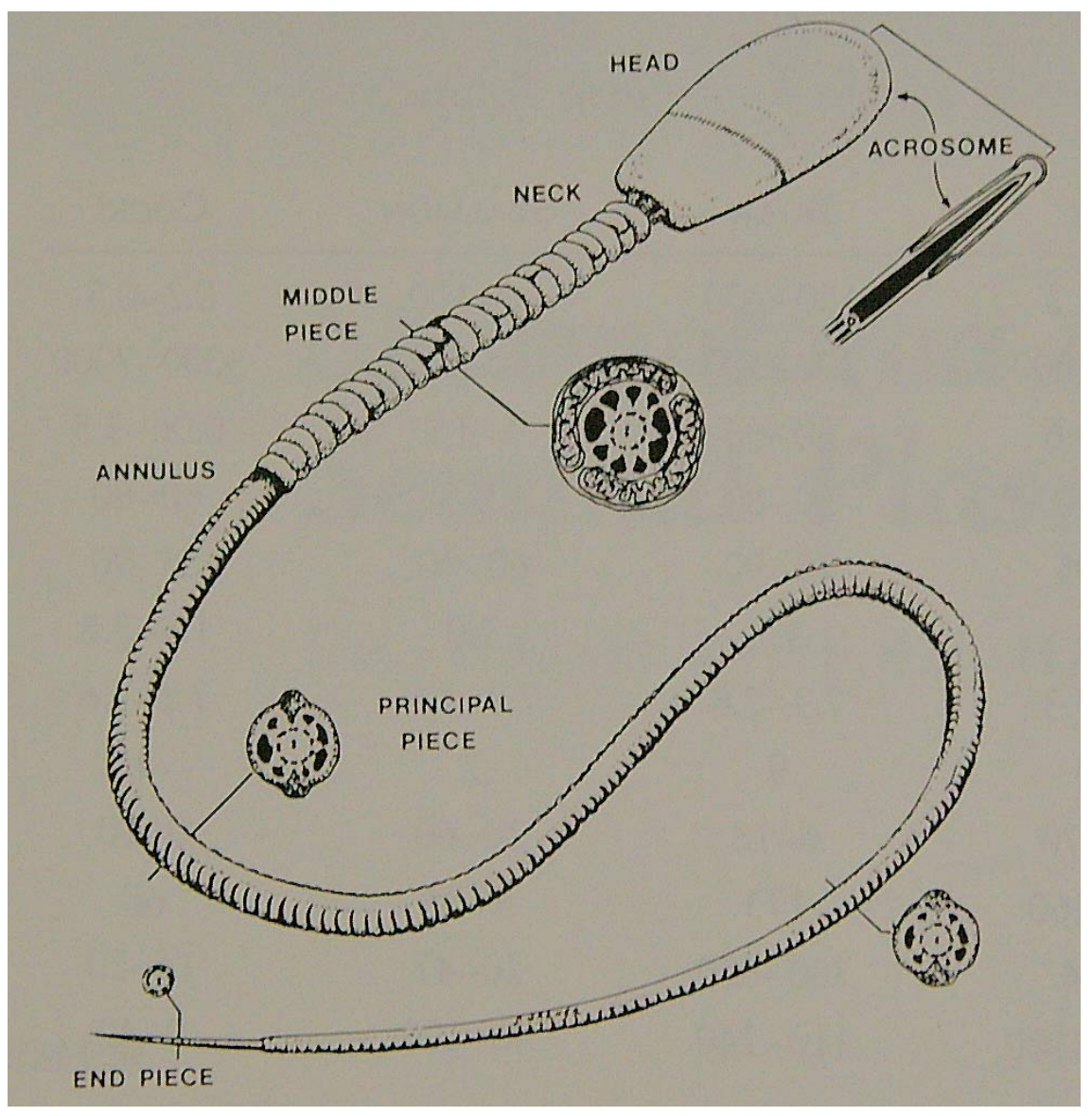




\subsubsection{Biochemistry of membranes}

Like all bio membranes the sperm membrane (plasma membrane) consists of proteins and lipids. The membranes grow and shrink with addition or withdrawal of lipids and proteins (Koolman and Röhm 1994). Gadella et al. (1999a) showed the highly dynamic structure of sperm membranes with their lipid composition. Fluidity, permeability, adhesivity and fusibility of the membranes can change due to external influences. The fluidity of membranes increases with temperature and with a growing amount of unsaturated fat acids (Koolman and Röhm 1994). The fluidity of the sperm head plasma membrane changes significantly during the cryo-preservation process (Canvin and Buhr 1989a, Buhr et al. 1989, Buhr and Pettitt 1996, Pettitt and Buhr 1998).

An intact sperm membrane is essential for full functionality of the sperm cell (KumiDiaka and Badtram 1994, Strom et al. 1997). The membrane structure of spermatozoa is highly correlated to extender components that support viability and motility of cryo-preserved spermatozoa (Pettitt and Buhr 1998). Alterations in membrane structure and function due to cryo-preservation are mainly responsible for reduced fertility of deep-frozen spermatozoa (Parks and Graham 1992b). Cryopreservation of the plasma membrane leads to a redistribution of proteins in the sperm head membrane (De Leeuw et al. 1991), to alterations of the amount of or to the destruction of phospholipids and fatty acids (Parks and Graham 1992b) and partly also to the destruction of the plasma integrity (Almlid and Johnson 1988, Almlid et al. 1989a).

\subsubsection{Capacitation}

Chang (1951) and Austin (1951) noted that sperm must reside in the female reproductive tract before becoming capable of attaching to and penetrating the oocyte. The spermatozoa are stored in the epididymis until ejaculation. The protective measurements and stabilization of spermatozoa during their storage in the epididymis have a strong evolutionary correlation with necessity for capacitation in the female genital tract (Bedford 1994). To fertilize the oocyte the spermatozoa will 
have to change from a stabilized status to an activated or capacitated status after ejaculation and deposition in the female (Töpfer-Petersen et al. 1996).

The capacitation process involves a series of endogen events like alteration of intracellular ion concentration, metabolism, redistribution of the sperm surface and a tyrosin-phosphorilation of sperm membrane proteins. These alterations are prerequisite for the zone pellucida induced acrosome reaction, the zone penetration and the fusion with the oocyte (Töpfer-Petersen et al. 1996, Kirchhoff 1995).

An important selection barrier for spermatozoa in the female genital tract is the utero-tubal-junction (UTJ). Only a few spermatozoa pass through the UTJ into the caudal isthmus (Hunter 1995). Obviously, the main events of capacitation take place in the lower segment of the isthmus (Hunter et al. 1987). Possibly, this is valid for all mammals, independent from the site of semen deposition (Yanagimachi 1994).

To initiate the capacitation as a process of progressive destabilisation, crucial for the later acrosome reaction, substances that are attached to or integrated in the sperm plasma membrane have to be removed or converted (Hunter and Greve 1998, Yanagimachi 1994). These substances are decapacitation factors (Fraser et al. 1990), Kaltrin, 15-, 16- and 23-kDa glykoproteins, all originating from the seminal plasma and $125-259-\mathrm{kDa}$ proteins from the epididymis (Yanagimachi 1994). Approximately 50-60 million molecules bind through protein-protein- and protein-lipid-interaction, preferably to the acrosomal region of the sperm head. Protease inhibitors are classical decapaciation factors. In pigs their binding to the sperm surface is mediated by the interaction with sperm adhesines from seminal plasma (Töpfer-Petersen et al. 1996). During in-vivo and in-vitro capacitation more than $90 \%$ of the sperm adhesines together with the protease inhibitors are relieved again. The remaining part (approx. 6-8 million molecules) remains bound tightly to the surface and is involved in primary sperm binding to the zona pellucida (Töpfer-Petersen et al. 1995a). Subgroups of sperm adhesines are believed to have different functions. They serve as decapacitation factors as well as acrosome stabilizer. Parts of the sperm adhesines are removed from the sperm membranes during the migration of spermatozoa from the uterus to the lower isthmus either passively or by interaction of the sperm cells with the epithelia cells of the female genital (Calvete et al. 1997). In species with intrauterine semen deposition the spermatozoa appear to capacitate in the most, if not all in the lower isthmus (Yanagimachi 1994, Calvete et al. 1997). Spermatozoa are 
capable to fully capacitate in the uterus without migrating to the oviduct (Brackett and Server 1970). They also can capacitate in the oviduct without any contact to the uterus (Bedford 1969). According to Bedford (1967) capacitation in rabbits is most effective when the spermatozoa have passed through uterus and oviduct.

Spermatozoa that underwent capacitation are membrane instable and short-lived (Bedford 1970). Therefore, capacitation has to occur in relation to ovulation. Hunter (1995) indicated that the full process of capacitation does not depend on the residence time of the spermatozoa in the lower isthmus, but is related to the time of ovulation. The time for boar sperm to fully capacitate takes about three hours (Hunter 1995).

According to Töpfer-Petersen et al. (1990, 1995b, 1996) capacitation leads to a total reorganisation of the sperm surface. During this process binding positions for the interaction with the oocyte and highly specialized micro-domains for fusion events of acrosome reaction are being developed. Furthermore, some second-messengersystems and elements of signal-transduction are activated, which are prerequisite for the induction of the acrosome reaction by the zona pellucida. But the key event for the capacitation is the removal of cholesterol from the membranes (Davis 1981) and the influx of calcium ions (Harrison et al. 1993). Harrison (1997) showed that capacitation is a specific, initiable and controllable process, in which bicarbonate plays a key role. The influx of bicarbonate into the sperm cell leads to a stimulation of adenylat cyclase. Cyclic AMP production is initiated as a second-messenger, which activates protein kinase-A and simultaneously impedes the phosphotyrosinphosphatase. Proteinkinase-A activates the protein-tyrosin-kinase, which finally causes capacitation (Visconti et al. 1998).

\subsubsection{Influence of seminal plasma}

During ejaculation spermatozoa are mixed with seminal plasma. Seminal plasma is the secretory product of the accessory glands in the male genital tract. Depending on species, the seminal plasma is build up by secretions of the ampoule, vesicular glands, prostate and bulbourethral glands. The secretions of the testicles and Ducti deferentia add only a minor part to the ejaculate (Töpfer-Petersen et al. 1998).

Seminal plasma is a complex mixture of different ions, low molecular organic substances, i.e. free amino acids, monosaccharides, lipids, polyamines, 
prostaglandins, steroid hormones and proteins (Mann and Lutwack-Mann 1981). It is not surprising that interactions between sperm transport, capacitation and timing of ovulation, are affected in a synchronizing matter by seminal plasma (Weitze et al. 1990a, Waberski et al. 1996). The effects are mainly related to a special peptide fraction (1-10 kDa) induced by seminal plasma estrogens (Waberski et al. 1996). During oestrus it was possible to advance ovulation after early administration of seminal plasma. This effect was only significant in sows that showed a long "oestrus to ovulation" interval (Waberski et al. 1996). The advancement of ovulation is based on a shortage of the interval between LH-surge and ovulation. The time point of the LH-surge was not influenced by seminal plasma administration (Waberski et al. 1997). Interestingly, it was not possible to advance the time of ovulation in sows that had been treated with 750 I.E. hCG (Soede et al. (1998). The authors also noticed that the composition of seminal plasma varied among boars.

Seminal plasma has been described to have a positive effect on the accumulation of fertile spermatozoa in the oviduct, possibly due to an improved sperm transport. Viring and Einarsson (1980) described a relaxing effect of seminal plasma on the isthmus of the oviduct, which could be beneficial to the transport of spermatozoa to the site of fertilization. Waberski et al. (1996) and Soares (1995) determined a higher number of accessory sperm in the zona pellucida when semen samples contained seminal plasma. Even after AI with reduced sperm numbers $\left(500 \times 10^{6}\right.$ and $300 \mathrm{x}$ $10^{6}$ ) the authors did not notice any significant differences in fertilization rates when seminal plasma was present.

Claus et al. (1988) and Claus (1990) described the effect of seminal plasma on uterine contractions. Seminal plasma estrogens induced the release of prostaglandins from the endometrium and thereby strengthened uterine contractions. Additionally, seminal plasma estrogens seem to accelerate sperm transportation, which might be an important regulative part of fertilization.

Seminal plasma has direct influence on sperm motility by specific activating and impeding substances (Acott and Hoskins 1978, Iwamoto et al. 1992). Also capacitation is influenced considerably by decapacitation factors in the seminal plasma as described above. Chang (1957) noticed that sperm capacitation is delayed by seminal plasma. Further it was possible to decapacitate spermatozoa if seminal plasma was added to a solution containing already capacitated spermatozoa. There 
are factors in seminal plasma, preventing capacitation and the subsequent fertilization unless removed (Dukelow et al. 1967). Also Calvete et al. (1997) described that removal of seminal plasma components has an important influence on capacitation.

Further, seminal plasma has an immuno-suppressive effect (Koch and Ellendorff 1985, Stanek et al. 1985) but partly also an immuno-stimulative effect in the female genital (Hadjisavas et al. 1994, Engelhardt et al. 1997). Immuno-suppressive components in seminal plasma with molecular weights of 100 and $110 \mathrm{kDa}$ were detected in boar semen (Bouvet et al. 1987). According to Stanek et al. (1985) the immunosuppressive effect is mainly directed against B-lymphocytes. Spermatozoa have antigenic characteristics and function as chemo tactical mediators, leading to a migration of polymorphonuclear granulocytes (PMN) due to complement activation (Troedsson et al. 1995). The addition of 20 to $30 \mathrm{ml}$ of seminal plasma reduced the spermatozoa-induced migration of PMN in the uterus lumen (Rozeboom et al. 1999). However, Engelhardt et al. (1997) found a massive increase of neutrophile granulocytes and macrophages in the endometrium of gilts after administration of seminal plasma. Leshin et al. (1998) were able to show an immune stimulatory effect of seminal plasma proteins PSP-I and PSP-II on T- and B-lymphocytes in vitro. It is possible that certain seminal plasma proteins stimulate the proliferation of lymphocytes, which then interact with or synthesize immunosuppressive substances. Possibly, these substances protect spermatozoa, zygotes, and embryos against an immunological defence by the female genital tract (Leshin et al. 1998).

Taylor et al. (2007) showed that seminal plasma prevents spermatozoa from being bound to the uterine epithelial, as well as to neutrophilic granulocytes, suggesting an important protective role. They concluded that seminal plasma exerts a protective role that might be helpful in low dose insemination because it prevents the selection of viable spermatozoa in the uterus and therefore increases the number of spermatozoa reaching the UTV (Taylor et al. 2007).

Maxwell et al. (1996) and Maxwell and Johnson (1997) showed that viability as well as membrane integrity of ram-, bull- and boar-spermatozoa were reduced after flow cytometric sorting. The changes of spermatozoa during flow cytometry could partly be prevented by addition of $10 \%$ seminal plasma to the sorting medium (Maxwell et al. 1996). 
Seminal plasma has an effect on the freezeability of boar spermatozoa. They are more prone to damage during cryo-preservation after contact to seminal vesicular secretions (Moore et al. (1977). Pena et al. (2003a, 2004b) and Selles et al. (2001) found differences in the post thaw sperm quality of different fractions of the ejaculate. In their study the sperm rich fraction tolerated handling and freezing better than the sperm poor fraction, indicating that seminal plasma has a negative influence on boar semen freezing.

\subsubsection{Acrosome reaction}

On successful binding of the spermatozoa to the oocyte the acrosome reaction is induced (Yanagimachi 1994). Only when spermatozoa are fully capacitated, they are capable to undergo acrosome reaction (Lee et al. 1987).

The induced acrosome reaction is distinguished from a spontaneous acrosome reaction. The spontaneous acrosome reaction takes place without influence of any external substances on the acrosome membrane, whereby the acrosome membrane lyses (Yanagimachi 1994). The induced acrosome reaction takes place on successful binding of the spermatozoon to the zona pellucida (Fazeli et al. 1997).

The acrosome reaction is a exocytotical process, whereby lytic enzymes are released. During the induced acrosome reaction, the outer acrosome membrane fuses at several locations with the zona pellucida. A cascade of different signal transductions is induced. The binding of the zona proteins to the receptors of the sperm membrane causes a depolarisation of the membrane and a stimulation of G-proteins. Calcium ion channels open and hydrogen ions are transported out of the cell. The intracellular calcium ion content increases. The $\mathrm{pH}-\mathrm{Value}$ of the cytosol changes to alkaline. Caused by G-proteins, the concentration of the second messenger IP3 and diacylglycerol (DG) increases. DG is a regulating element in the phosphorylisation cascade and causes an increase of intracellular calcium. Furthermore DG activates cGMP-ase and cAMP-ase and causes an increase of cyclic nucleotides in the cytosol (Serrano et al. 2001).

The cytosol now contains a higher concentration of IP3. Calcium is released from intracellular storages and binds to calmodulin, whereby several proteins are phosphorylated. Finally, the increased intracellular calcium concentration causes the 
acrosome reaction, with the release of the hydrolytic enzymes, stored in the acrosome. The acrosome reaction is essential for fertilization because the zona pellucida can only be penetrated by hyperactive spermatozoa, if a partial hydrolysis of the zona took place.

The binding and recognition of the two gametes is mediated by exposed carbohydrate-side-chains of the zona pellucida, which are being recognized by complementary receptors (zona-pellucida-binding proteins) of the spermatozoa (primary binding). After binding to the $\mathrm{ZP}$, the acrosome reaction is induced. The released enzymes result in the lysis of the zona pellucida and enable the secondary binding of spermatozoa to the zona pellucida and further the penetration of the sperm cell into the oocyte. Acrosine is one of the enzymes that is activated and released by the acrosome reaction. It takes part in the penetration process together with other enzymes. Acrosin has, beside its proteolytic characteristics, also lectinlike affinities for the carbohydrates of the ZP. It is discussed that Acrosin is responsible for the secondary binding after the acrosome reaction took place, to assure that acrosome reacted spermatozoa do not swim away from the ZP (TöpferPetersen and Aurich 2000). After penetration of the ZP the fusion of the side by side laying plasma membranes of spermatozoa and oocyte take place.

\subsection{Cryo-preservation methods for boar spermatozoa}

During evolution spermatozoa have developed from a somatic cell to a very specialized gamete cell with the only task to guarantee the genetic maintenance of DNA information, including the transport through the female genital tract (Yoshida 2000). Preservation methods have to account for this and should not only allow the survival of spermatozoa for an unlimited time period but also must not reduce the fertilizing ability significantly.

\subsubsection{History of Cryo-preservation}

Already in 1776 Spallanzani was able to observe sperm immobilization by cooling/freezing when he exposed spermatozoa from humans, stallions and frogs to 
snow (Spallanzani 1776). When he re-warmed them after 30 minutes they became motile again. A century later, Mantagazza (1866) observed that human spermatozoa survived when semen was frozen at $-17^{\circ} \mathrm{C}$. These two reports rank as the earliest in the recovery of mammalian cells after exposure to a temperature below their freezing point.

At least as important was the discovery of the cryoprotective potential of glycerol by Chris Polge (1949). He opened up an era of successful cryo-preservation methods, not only of gametes from various species, but also of other somatic cells and tissues. Fertility reports with deep frozen bull spermatozoa (Stewart 1951) led to intensive development of cryo-preservation methods that would be applicable for practical insemination purposes, including research efforts aiming at the development of a method for deep freezing of boar semen. Consequently, successful viability of frozen-thawed boar spermatozoa was reported (Polge 1956, Hoffmann 1959, Hess et al. 1960, Dukelow and Graham 1962, Bader 1964, King and Macpherson 1966, Kojima et al. 1967, Rohloff 1967, Bamba et al. 1968). 


\subsubsection{Development of cryo-preservation methods for boar semen}

After the discovery of glycerol as cryo-protectant for spermatozoa by Polge et al. (1949) intensive research has been conducted to improve the survival of spermatozoa after thawing. The development of the cryo-preservation methods and composition of cooling, freezing and thawing solutions has been reviewed by Bwanga et al. (1991). The subsequent research efforts in boar semen cryo-preservation are summarized in Table 1. 
Table 1: Recent reports about improving methods for cryo-preservation of boar semen

\begin{tabular}{|c|c|c|c|}
\hline Area of Research & Material and Methods & Results & Reference \\
\hline \multirow[t]{3}{*}{ Container } & $\begin{array}{l}\text { Post-thaw motility and membrane integrity of } \\
\text { spermatozoa frozen in maxi-straws or FlatPack- } \\
\text { container with different freezing }\left(20,50,80^{\circ} \mathrm{C} / \mathrm{min}\right) \\
\text { and thawing }\left(40 \mathrm{~s} \text { at } 50^{\circ} \mathrm{C} \text { or } 27 \mathrm{~s} \text { at } 70^{\circ} \mathrm{C} \text { for Maxi- }\right. \\
\text { straws and } 23 \mathrm{~s} \text { at } 35^{\circ} \mathrm{C}, 13 \mathrm{~s} \text { at } 50^{\circ} \mathrm{C} \text { or } 8 \mathrm{~s} \text { at } 70^{\circ} \mathrm{C} \\
\text { for the FlatPacks) curves was evaluated }\end{array}$ & $\begin{array}{l}\text { Freezing at a rate of }-50^{\circ} \mathrm{C} \text { resulted in slightly } \\
\text { better sperm quality post thaw, semen frozen in } \\
\text { FlatPack container showed better post thaw } \\
\text { motility, due to more equal thawing of the sample }\end{array}$ & $\begin{array}{l}\text { Eriksson and Rodriguez- } \\
\text { Martinez 2000d }\end{array}$ \\
\hline & $\begin{array}{l}\text { Motility and membrane integrity of spermatozoa } \\
\text { from nine boars frozen with a programmable } \\
\text { freezing machine in plastic bags, 'cochettes', and in } \\
\text { 'maxi-straws', in total doses of } 5 \times 10^{9} \text { spermatozoa/5 } \\
\text { ml with glycerol ( } 3 \%) \text { used as cryo-protectant, were } \\
\text { assessed after thawing }\end{array}$ & $\begin{array}{l}\text { Cochettes sustained the overall procedure of } \\
\text { freezing/thawing, with } 30 \text { min post-thaw sperm } \\
\text { motility being significantly higher than for straws, } \\
46.9 \text { vs. } 39.5 \% \text {; percentages of FT-spermatozoa } \\
\text { with intact membranes, detected with the supra- } \\
\text { vital probes, were higher in maxi-straws than in } \\
\text { cochettes, } 46.8 \text { vs. } 43.0 \% \text {; no significant } \\
\text { differences were found in fertilizing capacity } \\
\text { between spermatozoa frozen in maxi-straws and } \\
\text { those frozen in cochettes }\end{array}$ & $\begin{array}{l}\text { Eriksson and Rodriguez- } \\
\text { Martinez 2000c }\end{array}$ \\
\hline & $\begin{array}{l}\text { Fertility of boar spermatozoa frozen in } 0.5 \mathrm{ml} \text { and } \\
5 \mathrm{ml} \text { straws was evaluated }\end{array}$ & $\begin{array}{l}\text { Freezing in } 5 \mathrm{ml} \text { straws did not have any } \\
\text { detrimental effect on either penetration, } \\
\text { monospermy, polyspermy, motility and NAR, in } \\
\text { comparison with freezing in } 0.5 \mathrm{ml} \text { straws }\end{array}$ & Cordova et al. 2001 \\
\hline
\end{tabular}




\begin{tabular}{|c|c|c|c|}
\hline Area of Research & Material and Methods & Results & Reference \\
\hline & $\begin{array}{l}\text { Frozen-thawed semen from } 0.5 \text { and } 5 \mathrm{ml} \text { straws was } \\
\text { compared to fresh semen and subjected to IVF after } \\
\text { thawing }\end{array}$ & $\begin{array}{l}\text { Semen frozen in } 0.5 \mathrm{ml} \text { straws showed higher rates } \\
\text { for motility, NAR and lower rates for sperm } \\
\text { penetration, monospermy, polyspermy, chromatin } \\
\text { was significantly more unstable in sperm frozen in } \\
0.5 \mathrm{ml} \text { straws }\end{array}$ & Cordova et al. 2002 \\
\hline & $\begin{array}{l}2 \times 10^{9} \text { spermatozoa per } \mathrm{ml} \text { were frozen either in } \\
0.5 \mathrm{ml} \text { medium straw, in } 0.7 \mathrm{ml} \text { FlatPack; } 5 \times 10^{9} \text { in a } \\
5 \mathrm{ml} \text { FlatPack served as control }\end{array}$ & $\begin{array}{l}\text { Sperm motility did not differ between packages, } \\
\text { viability was higher for } 0.7 \mathrm{ml} \text { FlatPack; } \\
\text { spermatozoa could successfully be frozen in small } \\
\text { volumes }\end{array}$ & Saravia et al. 2005 \\
\hline Freezing/Thawing curve & $\begin{array}{l}\text { Three different freezing curves and three different } \\
\text { container systems were compared }\end{array}$ & $\begin{array}{l}\text { Best post-thaw sperm motility and percentage of } \\
\text { NAR was obtained with semen frozen in } 0.25 \mathrm{ml} \\
\text { Ministraws, } 5 \mathrm{ml} \text { Maxistraws and } 5 \mathrm{ml} \text { FEP-plastic } \\
\text { bags, the best freezing curve was from }+5 \text { to }-6^{\circ} \mathrm{C} \\
\text { at }-3^{\circ} \mathrm{C} / \mathrm{min} \text {, hold } 1 \mathrm{~min} \text { at }-6^{\circ} \mathrm{C} \text {, at }-20^{\circ} \mathrm{C} / \mathrm{min} \text { to - } \\
100^{\circ} \mathrm{C}\end{array}$ & Bwanga et al. 1991a \\
\hline & $\begin{array}{l}\text { The effect of thawing velocities (from } 10 \text { to } \\
\left.1,800^{\circ} \mathrm{C} / \mathrm{min}\right) \text { in dependence from freezing rate ( } 1 \text { - } \\
\left.30^{\circ} \mathrm{C} / \mathrm{min}\right) \text { and glycerol level }(2,4,6 \%) \text { on sperm } \\
\text { motility and NAR were tested }\end{array}$ & $\begin{array}{l}\text { The best post-thaw motility }(44-46 \%) \text { was reached } \\
\text { with } 4-6 \% \text { glycerol at a freezing rate of } 30^{\circ} \mathrm{C} / \mathrm{min} \\
\text { and a thawing rate of } 1200^{\circ} \mathrm{C} / \mathrm{min} \text {; the percentage } \\
\text { of NAR increased with the thawing rate, but was } \\
\text { negatively affected by glycerol concentration at a } \\
\text { freezing rate of } 1^{\circ} \mathrm{C} / \mathrm{min}\end{array}$ & Fiser et al. 1993 \\
\hline
\end{tabular}




\begin{tabular}{|c|c|c|c|}
\hline Area of Research & Material and Methods & Results & Reference \\
\hline & $\begin{array}{l}\text { Three different freezing procedures were compared: } \\
\text { 1) sperm rich fraction, cooled to } 20^{\circ} \mathrm{C} \text { and hold } \\
\text { 1.5hrs, subsequent cooling to } 15^{\circ} \mathrm{C} \text { within } 2.5 \mathrm{hrs} \text {; 2) } \\
\text { sperm rich fraction, cooling to }+18 \text { degrees } \mathrm{C} \text { for } 4 \mathrm{~h} \\
\text { and subsequent holding time at }+18 \text { degrees } \mathrm{C} \text { for } 16 \\
\mathrm{~h} ; 3 \text { ) whole ejaculate (sperm rich fraction plus } \\
\text { seminal plasma), cooling to }+18 \text { degrees } \mathrm{C} \text { for } 4 \mathrm{~h} \\
\text { and subsequent holding time at }+18 \text { degrees } \mathrm{C} \text { for } 16 \\
\mathrm{~h} \text {; }\end{array}$ & $\begin{array}{l}\text { Sperm motility and NAR were significantly better } \\
\text { with procedures } 2 \text { and } 3 \text { indicating a positive effect } \\
\text { of extended holding time, exposure to seminal } \\
\text { plasma had no significant effect }\end{array}$ & $\begin{array}{l}\text { Kotzias-Bandeira et al. } \\
1997\end{array}$ \\
\hline & $\begin{array}{l}\text { The influence of prolonged storage of boar } \\
\text { epididymes }\left(0-3 \text { days at } 4^{\circ} \mathrm{C}\right) \text { on post-thaw motility } \\
\text { and IVF was evaluated }\end{array}$ & $\begin{array}{l}\text { Data indicated that epididymal spermatozoa can be } \\
\text { stored up to two days at } 4^{\circ} \mathrm{C} \text { prior to freezing } \\
\text { before successful IVF }\end{array}$ & Kikuchi et al. 1998 \\
\hline
\end{tabular}




\begin{tabular}{|c|c|c|c|}
\hline Area of Research & Material and Methods & Results & Reference \\
\hline & $\begin{array}{l}\text { Semen was frozen in a split-sample design using } 3 \\
\text { different holding times }(3,10 \text { and } 20 \mathrm{~h}) \text { during } \\
\text { cooling and three different types of freezing package: } \\
\text { Maxi-straws, Medium-straws and FlatPacks; in vitro } \\
\text { oocyte penetration ability of the spermatozoa was } \\
\text { tested }\end{array}$ & $\begin{array}{l}\text { Post-thaw sperm motility was significantly higher } \\
\text { for } 10 \mathrm{~h} \text { and } 20 \mathrm{~h} \text { holding time compared with } 3 \mathrm{~h} \text {, } \\
\text { and the percentage of motile spermatozoa } \\
\text { decreased significantly with } 20 \mathrm{~h} \text { holding time as } \\
\text { opposed to } 3 \mathrm{~h} \text { and } 10 \mathrm{~h} \text {; regarding the freezing } \\
\text { packages, the FlatPacks and Maxi-straws yielded } \\
\text { significantly more motile sperm than did the } \\
\text { Medium-straws; motility was significantly higher } \\
\text { for FlatPacks than for straws, in terms of both } \\
\text { percentage motile spermatozoa, and sperm } \\
\text { velocity and lateral head displacement; IVF did } \\
\text { not show any significant differences among the } \\
\text { holding time, although FlatPacks yielded a } \\
\text { significantly higher penetration rate and more } \\
\text { spermatozoa per penetrated oocyte (p<0.05) than } \\
\text { did the straws }\end{array}$ & Eriksson et al. 2001 \\
\hline & $\begin{array}{l}\text { Different freezing curves were used to freeze boar } \\
\text { spermatozoa and evaluated for motility, viability, } \\
\text { and acrosomal integrity in the membrane-intact } \\
\text { population }\end{array}$ & $\begin{array}{l}-30 \text { or }-50 \text { degrees } \mathrm{C} / \mathrm{min} \text { showed better results } \\
\text { than }-1 \text { degrees } \mathrm{C} / \mathrm{min} \text {, with a slight advantage } \\
\text { being evident for }-30 \text { degrees } \mathrm{C} / \mathrm{min}\end{array}$ & Kumar et al. 2003 \\
\hline
\end{tabular}




\begin{tabular}{|c|c|c|c|}
\hline Area of Research & Material and Methods & Results & Reference \\
\hline & $\begin{array}{l}\text { Two thawing procedures were analysed }\left(37^{\circ} \mathrm{C}, 30 \mathrm{~s} \text {; }\right. \\
\left.50^{\circ} \mathrm{C}, 12 \mathrm{~s}\right) \text { and thawed spermatozoa were subjected } \\
\text { to IVF }\end{array}$ & $\begin{array}{l}\text { No differences in sperm quality where found, with } \\
50 \text { degrees } C, 12 \mathrm{~s} \text { the IVF results showed a higher } \\
\text { number of sperm per penetrated oocyte and a near } \\
10 \text { points higher rate of pronuclear formation }\end{array}$ & Selles et al. 2003 \\
\hline & $\begin{array}{l}\text { New freezing technique was used; semen was diluted } \\
\text { in L-EY, Glycerol diluents and cooled to }-25^{\circ} \mathrm{C} \text { at } \\
\text { different rates in cryo-tubes in a liquid environment, } \\
\text { samples were subsequently plunged into liquid } \\
\text { nitrogen, thawing was done at room temperature for } \\
45 \mathrm{~s} \text { and then for } 5 \text { min at } 37^{\circ} \mathrm{C} \text { in a water bath, } \\
\text { thawed semen was used for AI }\end{array}$ & $\begin{array}{l}\text { Cooling of semen within } 5 \text { min to }-10^{\circ} \mathrm{C} \text { and then } \\
\text { within } 4 \text { min to }-25^{\circ} \mathrm{C} \text { showed best post thawing } \\
\text { motility, motility was significantly better than } \\
\text { control sperm frozen in straws, fertility trial } \\
\text { proved fertility of spermatozoa frozen with new } \\
\text { technique }\end{array}$ & Goolsby et al. 2004 \\
\hline & $\begin{array}{l}\text { Three different centrifugation regimes }(\mathrm{C} 1: 2400 \mathrm{x} g \\
\text { for } 3 \text { minutes }),(\mathrm{C} 2: 1600 \mathrm{x} \mathrm{g} \text { for } 5 \text { minutes })(\mathrm{C} 3: 800 \\
\mathrm{x} g \text { for } 10 \text { minutes }) \text { for sperm concentration at } 15^{\circ} \mathrm{C} \\
\text { were compared }\end{array}$ & $\begin{array}{l}\text { C1 and C2 showed significantly higher post-thaw } \\
\text { sperm motility, viability, and percentage of non } \\
\text { capacitated sperm; C1 had the highest oocyte } \\
\text { penetrating ability and did not affect sperm yield }\end{array}$ & Carvajal et al. 2004 \\
\hline & $\begin{array}{l}\text { Seeding of super-cooled sperm samples at }-5 \text { or - } \\
15^{\circ} \mathrm{C} \text { was tested in a cryo-microscope }\end{array}$ & $\begin{array}{l}\text { Percentage of membrane intact sperm was higher } \\
\text { after seeding at }-15^{\circ} \mathrm{C} \text {, but percentage of NAR was } \\
\text { higher in samples seeded at }-5^{\circ} \mathrm{C}\end{array}$ & Woelders et al. 2005 \\
\hline
\end{tabular}




\begin{tabular}{|c|c|c|c|}
\hline Area of Research & Material and Methods & Results & Reference \\
\hline & $\begin{array}{l}\text { Two different holding times ( } 3 \text { vs. } 24 \text { hrs) at } 15^{\circ} \mathrm{C} \\
\text { were compared; two different extenders were also } \\
\text { compared (BTS vs. Androhep Plus) }\end{array}$ & $\begin{array}{l}\text { No differences in pregnancy rate at } 23 \text { days was } \\
\text { detected but embryo number was decreased after } \\
24 \text { hrs. holding time; increasing holding time did } \\
\text { not affect post-thaw motility in BTS but decreased } \\
\text { motility after increased holding in Androhep Plus }\end{array}$ & Guthrie and Welch 2005 \\
\hline Composition of media & $\begin{array}{l}\text { Two concentrations of glycerol ( } 2 \% \text { vs. } 6 \%) \text { and } \\
\text { three fractions of thawed spermatozoa (Percoll- } \\
\text { Gradient centrifugation, Swim-up, supernatant } \\
\text { fraction after centrifugation) where compared, f/t } \\
\text { spermatozoa where subsequently used for IVF }\end{array}$ & $\begin{array}{l}\text { Raising the glycerol concentration decreased the } \\
\text { proportion of NAR, spermatozoa from supernatant } \\
\text { fraction showed highest rate of penetration and } \\
\text { polyspermy, penetration rate was similar to that } \\
\text { with IVF of fresh semen, but polyspermy rate was } \\
\text { lower, pronuclear formation was higher }\end{array}$ & Zheng et al. 1992 \\
\hline & $\begin{array}{l}\text { The influence of 2-hydroxyproyl-beta-cyclodextrin } \\
\text { (HBCD) exposure for } 3 \mathrm{hrs} \text { on post-thaw sperm prior } \\
\text { to freezing in pellets was evaluated }\end{array}$ & $\begin{array}{l}\text { HBCD significantly improved post-thaw motility } \\
\text { and acrosome integrity was three-fold higher with } \\
40 \mathrm{mmol} H B C D \text { than in the control group possibly } \\
\text { indicating a stimulating effect on the efflux of } \\
\text { membrane cholesterol }\end{array}$ & Zeng and Terada 2000 \\
\hline
\end{tabular}




\section{Area of Research}

Material and Methods

Effects of freezing diluents of differing levels of osmolality (225-580 mOsm/kg) on boar sperm cryosurvival were tested

\section{Results}

Highest motility was found in the $420 \mathrm{mOsm} / \mathrm{kg}$ group, and progressive motility in the 420 to 580 $\mathrm{mOsm} / \mathrm{kg}$ groups was higher than that in the hypo(225 mOsm $/ \mathrm{kg}$ ) and iso-osmotic (290 mOsm $/ \mathrm{kg})$ groups; intact acrosomes of the spermatozoa

frozen in the 510 and $580 \mathrm{mOsm} / \mathrm{kg}$ BF5 diluents were more numerous than in other groups; the 420 and $510 \mathrm{mOsm} / \mathrm{kg}$ groups yielded maximal values of post-thaw membrane integrity; study indicates that moderately hypertonic BF5 diluents are favourable for the cryo-preservation of boar spermatozoa in pellets

\section{Reference}

Zeng et al. 2001 


\begin{tabular}{|c|c|c|c|}
\hline Area of Research & Material and Methods & Results & Reference \\
\hline & $\begin{array}{l}\text { Spermatozoa were exposed to methyl-beta- } \\
\text { cyclodextrin (MBCD) or a combination of MBCD } \\
\text { and cholesterol-3-sulfate over a period of } 3 \text { hours } \\
\text { while being cooled slowly from } 25 \text { degrees C to } 5 \\
\text { degrees C, and were subsequently cryopreserved by } \\
\text { the pellet method }\end{array}$ & $\begin{array}{l}\text { In post-thaw spermatozoa the values of the intact } \\
\text { acrosome, motility, progressive motility, } \\
\text { progressive velocity, straightness, and linearity of } \\
\text { the cell path increased greatly with the } \\
\text { concentration of MBCD; lateral head displacement } \\
\text { amplitude and the beat cross-frequency of post- } \\
\text { thaw spermatozoa were not different among all } \\
\text { treatments; addition of cholesterol-3-sulfate to the } \\
\text { diluent containing MBCD abolished the protective } \\
\text { effect against freeze-thaw injury that MBCD } \\
\text { provides to spermatozoa; results indicate that } \\
\text { cryosurvival of boar spermatozoa is enhanced by } \\
\text { exposure to MBCD before freezing }\end{array}$ & Zeng and Terada 2001 \\
\hline & $\begin{array}{l}\text { Effect of N-acetyl-D-glucosamine, glycerol } \\
\text { concentration and equilibration time for the freezing } \\
\text { of boar spermatozoa in } 5 \mathrm{ml} \text { maxi-straws was } \\
\text { evaluated }\end{array}$ & $\begin{array}{l}\text { Best results were obtained with first diluent } \\
\text { containing } 11 \% \text { lactose hydrate, } 20 \% \text { egg yolk and } \\
0.05 \% \mathrm{~N} \text {-acetyl-D-glucosamine in } 100 \mathrm{ml} \text { distilled } \\
\text { water, and the second diluent containing } 11 \% \\
\text { lactose hydrate, } 20 \% \text { egg yolk, } 4 \% \text { glycerol and } \\
1 \% \text { orvus es paste }\end{array}$ & Yi et al. 2002a \\
\hline
\end{tabular}




\begin{tabular}{|c|c|c|c|}
\hline Area of Research & Material and Methods & Results & Reference \\
\hline & $\begin{array}{l}\text { Experiments were carried out to investigate the effect } \\
\text { of N-acetyl-D-glucosamine, and to obtain additional } \\
\text { information about the effect of Orvus Es Paste (OEP) } \\
\text { and egg yolk concentration in the freezing of boar } \\
\text { sperm in the maxi-straw }\end{array}$ & $\begin{array}{l}\text { Diluent with } 0.025 \text { or } 0.05 \% \text { soluble N-acetyl-D- } \\
\text { glucosamine in the first diluent, } 0.5 \% \text { final Orvus } \\
\text { Es Paste concentration and } 20 \% \text { egg yolk } \\
\text { concentration significantly enhanced NAR } \\
\text { acrosomes and motility of boar sperm after } \\
\text { freezing and thawing; no effects of N-acetyl-D- } \\
\text { glucosamine among the diluents with or without } \\
\text { N-acetyl-D-glucosamine at the second dilution }\end{array}$ & Yi et al. $2002 b$ \\
\hline & $\begin{array}{l}\text { Effect of addition of either } 500 \text { or } 1000 \mu \mathrm{g} / \mathrm{ml} \\
\text { hyaluronan prior to freezing on post-thaw sperm } \\
\text { characteristics was evaluated }\end{array}$ & $\begin{array}{l}\text { Hyaluronan supplementation improved sperm } \\
\text { motility, decreased percentage of hyperactive } \\
\text { spermatozoa and maintained membrane stability as } \\
\text { assessed with merocyanine- } 540\end{array}$ & Pena et al. 2004a \\
\hline
\end{tabular}




\begin{tabular}{|c|c|c|c|}
\hline Area of Research & Material and Methods & Results & Reference \\
\hline & $\begin{array}{l}\text { Spermatozoa were frozen with three different types } \\
\text { of avian EY (chicken, duck or quail) }\end{array}$ & $\begin{array}{l}\text { Sperm frozen in medium containing chicken egg } \\
\text { yolk displayed higher motility immediately after } \\
\text { thawing, but there was no difference in the } \\
\text { motility of sperm frozen with different types of } \\
\text { egg yolk } 3 \text { or } 6 \text { h after thawing and maintenance at } \\
37 \text { degrees C; sperm frozen in media containing } \\
\text { chicken or duck egg yolk had a higher proportion } \\
\text { of intact acrosomes immediately after thawing } \\
\text { than sperm frozen in medium containing quail egg } \\
\text { yolk, but } 6 \text { h after thawing and maintenance at } 37 \\
\text { degrees C the sperm that had been frozen in } \\
\text { medium containing chicken egg yolk had a higher } \\
\text { proportion of intact acrosomes than the sperm } \\
\text { frozen in media containing duck or quail egg yolk }\end{array}$ & Bathgate et al. 2006 \\
\hline & $\begin{array}{l}\text { Spermatozoa were frozen with the addition of low } \\
\text { density lipoproteins (LDL) }\end{array}$ & $\begin{array}{l}\text { LDL addition of } 9 \% \text { in the freezing media showed } \\
\text { an improved protection of the DNA integrity as } \\
\text { assessed by neutral comet assay }\end{array}$ & Jiang et al. 2006 \\
\hline
\end{tabular}




\begin{tabular}{|c|c|c|c|}
\hline Area of Research & Material and Methods & Results & Reference \\
\hline & $\begin{array}{l}\text { Freezing medium was supplemented with either } \\
\text { platelet-activating factor (PAF) or a recombinant } \\
\text { platelet-activating factor:acetylhydrolase (PAF:AH; } \\
\text { Pafase) before or after freezing }\end{array}$ & $\begin{array}{l}\text { Addition of PAF to the cryopreservation medium } \\
\text { improved post-thaw motility immediately after } \\
\text { thawing and after } 3 \mathrm{~h} \text { incubation at } 37^{\circ} \mathrm{C} \text {; } \\
\text { Acrosome integrity was higher immediately after } \\
\text { thawing and after } 3 \text { and } 6 \mathrm{~h} \text { incubation at } 37^{\circ} \mathrm{C} \\
\text { when sperm were frozen in the presence of Pafase; } \\
\text { Addition of PAF to sperm after thawing improved } \\
\text { motility immediately post-thaw, compared with } \\
\text { addition of Pafase or the control sperm with no } \\
\text { supplementation of the medium; the beneficial } \\
\text { effect was lost by } 3 \mathrm{~h} \text { post-thaw }\end{array}$ & Bathgate et al. 2007 \\
\hline & $\begin{array}{l}\text { Dialysis was used to remove low-molecular weight } \\
\text { components }(12-14 \mathrm{kDa}) \text { in boar semen, }\end{array}$ & $\begin{array}{l}\text { Dialysis enhanced post-thaw sperm motility, } \\
\text { plasma membrane integrity and mitochondrial } \\
\text { function, but had no significant effect on recovery } \\
\text { of spermatozoa with intact acrosomes. } \\
\text { Furthermore, dialyzed spermatozoa exhibited } \\
\text { higher ATP content compared with the control } \\
\text { after freezing-thawing }\end{array}$ & Fraser et al. 2007 \\
\hline
\end{tabular}




\section{Area of Research}

\section{Material and Methods}

Effect of lactose and glycerol concentration, as well

as the equilibration time with glycerol was studied

on motility, normal apical ridge, and chromatin state

of boar spermatozoa after the freezing and thawing

process
Results

Results indicated that freezing spermatozoa in

extenders with increasing concentrations of lactose

adversely affected motility but provided a

protective effect on acrosomes; increased lactose

concentration induced higher chromatin

condensation but maintained the same stability;

increasing the glycerol concentration in the

freezing extender from 4-6 to $8 \%$ led to higher

motility and NAR as well as lower chromatin

condensation and stability
Reference

Corcuera et al. 2007 
Although several improvements have been made to freeze boar semen, no major breakthrough in cell survival could be realised leading to a broader utilization of frozen-thawed semen in porcine industry. Due to the fact that still many spermatozoa are lost during freezing and thawing, new research efforts aim to use frozen / thawed spermatozoa more effectively for insemination in order to ensure a sufficient sperm population to be built up as sperm reservoir at the UTJ. For fresh semen AI the introduction of non-surgical deep intrauterine insemination (DUI) made it possible to reduce the required sperm dose 20 to 80 times (Vazquez et al. 1999, Martinez et al. 2001). Roca et al. (2003) used the same insemination technique to reduce the sperm dose of frozen-thawed spermatozoa from 6 to $1 \times 10^{9}$ without compromising farrowing rate or litter size.

Several field trials have been conducted to approve the improvements of cryopreservation as shown on laboratory level. Table 2 summarizes the major publications since this has been last reviewed by Johnson (1985).

Summarizing these trials, it can be seen that nearly all authors still use lactose-egg yolk for preparation of the cooling and freezing media for boar sperm. Also the fertility of frozen boar semen is still reduced compared to AI with fresh semen, as expressed by lower pregnancy rates and number of piglets or embryo and this even though higher sperm doses than in AI with fresh semen were used. On the other hand, some huge field trials show, that frozen boar semen can be integrated into the animal industry and applied on farm level. 
Table 2: $\quad$ Summary of fertility results with frozen/thawed boar semen, 1985-2007

\begin{tabular}{|c|c|c|c|c|c|c|c|c|c|c|c|}
\hline $\begin{array}{l}\text { Freezing } \\
\text { procedure }\end{array}$ & $\begin{array}{l}\text { Diluent/ } \\
\text { additives }\end{array}$ & $\begin{array}{l}\text { Thawing } \\
\text { procedure }\end{array}$ & $\begin{array}{l}\text { Insemination } \\
\text { dose }\end{array}$ & Site of AI & $\begin{array}{l}\text { No. } \\
\text { insem. }\end{array}$ & $\begin{array}{l}\text { AI per } \\
\text { oestrous }\end{array}$ & $\begin{array}{l}\% \\
\text { Pregnant }\end{array}$ & $\begin{array}{l}\text { Embryos/ } \\
\text { Piglets (E/P) }\end{array}$ & Conclusion & Comment & Reference \\
\hline $\begin{array}{l}\text { L-EY, OEP, } \\
\text { Glycerol }\end{array}$ & & $?$ & $3 \times 10^{9}$ & Cervical & 172 & & 66.8 & $?$ & $\begin{array}{l}\text { It was not } \\
\text { statistically } \\
\text { proved that } \\
\text { percentage } \\
\text { of NAR had } \\
\text { positive } \\
\text { effect on } \\
\text { fertility }\end{array}$ & & Premzl 1985 \\
\hline Pellet (BF5) & & $\begin{array}{l}\text { In BTS at } \\
42^{\circ} \mathrm{C}\end{array}$ & $6 \times 10^{9}$ & Cervical & 200 & 1 & $\begin{array}{l}50 \% \\
\text { Farrowing } \\
\text { Rate }\end{array}$ & $7.4 \mathrm{P}$ & $\begin{array}{l}\text { A broad } \\
\text { variety in } \\
\text { fertility } \\
\text { between } \\
\text { boars and } \\
\text { consignment } \\
\text { was detected }\end{array}$ & $\begin{array}{l}\text { Fertility } \\
\text { results } \\
\text { from six } \\
\text { export } \\
\text { consignme } \\
\text { nts to four } \\
\text { countries }\end{array}$ & $\begin{array}{l}\text { Curnock and } \\
\text { Reed } 1985\end{array}$ \\
\hline
\end{tabular}


$\underline{\text { Review of Literature }}$

\begin{tabular}{|c|c|c|c|c|c|c|c|c|c|c|c|}
\hline $\begin{array}{l}\text { Freezing } \\
\text { procedure }\end{array}$ & $\begin{array}{l}\text { Diluent/ } \\
\text { additives }\end{array}$ & $\begin{array}{l}\text { Thawing } \\
\text { procedure }\end{array}$ & $\begin{array}{l}\text { Insemination } \\
\text { dose }\end{array}$ & Site of AI & $\begin{array}{l}\text { No. } \\
\text { insem. }\end{array}$ & $\begin{array}{l}\text { AI per } \\
\text { oestrous }\end{array}$ & $\begin{array}{l}\% \\
\text { Pregnant }\end{array}$ & $\begin{array}{l}\text { Embryos/ } \\
\text { Piglets (E/P) }\end{array}$ & Conclusion & Comment & Reference \\
\hline Pellet & $\begin{array}{l}\text { Glucose, } \\
\text { EDTA, } \\
\text { Saccharose }\end{array}$ & $\begin{array}{l}\text { Dry at } \\
42^{\circ} \mathrm{C}\end{array}$ & $?$ & & 5 & & $40 \%$ & $7.5 \mathrm{P}$ & $\begin{array}{l}\text { Six years of } \\
\text { semen } \\
\text { storage did } \\
\text { not cause } \\
\text { further } \\
\text { substantial } \\
\text { changes in } \\
\text { the } \\
\text { structural } \\
\text { and } \\
\text { functional } \\
\text { characteristi } \\
\text { cs of } \\
\text { spermatozoa }\end{array}$ & $\begin{array}{l}\text { Semen } \\
\text { stored for } \\
6 \text { years }\end{array}$ & $\begin{array}{l}\text { Kozumplik } \\
1985\end{array}$ \\
\hline $\begin{array}{l}\text { L-EY, OEP, } \\
\text { Glycerol }\end{array}$ & & $50^{\circ} \mathrm{C} 50 \mathrm{~s}$ & $5 \times 10^{9}$ & Cervical & 132 & 1 & $\begin{array}{l}58 \% \\
\text { Farrowing } \\
\text { rate }\end{array}$ & $9.7 \mathrm{P}$ & $\begin{array}{l}\text { A higher but } \\
\text { not }\end{array}$ & $\begin{array}{l}\text { frozen in } \\
5 \mathrm{ml} \text { or }\end{array}$ & $\begin{array}{l}\text { Almlid et al. } \\
1987\end{array}$ \\
\hline
\end{tabular}


$\underline{\text { Review of Literature }}$

\begin{tabular}{|c|c|c|c|c|c|c|c|c|c|c|c|}
\hline $\begin{array}{l}\text { Freezing } \\
\text { procedure }\end{array}$ & $\begin{array}{l}\text { Diluent/ } \\
\text { additives }\end{array}$ & $\begin{array}{l}\text { Thawing } \\
\text { procedure }\end{array}$ & $\begin{array}{l}\text { Insemination } \\
\text { dose }\end{array}$ & Site of AI & $\begin{array}{l}\text { No. } \\
\text { insem. }\end{array}$ & $\begin{array}{l}\text { AI per } \\
\text { oestrous }\end{array}$ & $\begin{array}{l}\% \\
\text { Pregnant }\end{array}$ & $\begin{array}{l}\text { Embryos/ } \\
\text { Piglets (E/P) }\end{array}$ & Conclusion & Comment & Reference \\
\hline & & & & & 118 & 2 & $\begin{array}{l}68 \% \\
\text { Farrowing } \\
\text { rate }\end{array}$ & $9.6 \mathrm{P}$ & $\begin{array}{l}\text { significant } \\
\text { farrowing } \\
\text { rate was } \\
\text { observed } \\
\text { with double } \\
\text { AI }\end{array}$ & $\begin{array}{l}2.5 \mathrm{ml} \\
\text { straws }\end{array}$ & \\
\hline $\begin{array}{l}\text { L-EY, OEP, } \\
\text { Glycerol }\end{array}$ & & $50^{\circ} \mathrm{C} 40 \mathrm{~s}$ & $5 \times 10^{9}$ & Cervical & 26 & 1 & $80.8 \%$ & $?$ & $\begin{array}{l}\text { Conception } \\
\text { rate was } \\
\text { equal for } 2 \\
\text { and } 4 \% \\
\text { Glycerol but } \\
\text { in vitro } \\
\text { parameter } \\
\text { were better } \\
\text { with } 4 \%\end{array}$ & $\begin{array}{l}\text { Frozen } \\
\text { with 2\% } \\
\text { Glycerol } \\
\text { in Maxi- } \\
\text { Straws } \\
\text { Frozen } \\
\text { with 4\% } \\
\text { Glycerol } \\
\text { in Maxi- } \\
\text { Straws }\end{array}$ & $\begin{array}{l}\text { Almlid et al. } \\
\text { 1989b }\end{array}$ \\
\hline
\end{tabular}


$\underline{\text { Review of Literature }}$

\begin{tabular}{|c|c|c|c|c|c|c|c|c|c|c|c|}
\hline $\begin{array}{l}\text { Freezing } \\
\text { procedure }\end{array}$ & $\begin{array}{l}\text { Diluent/ } \\
\text { additives }\end{array}$ & $\begin{array}{l}\text { Thawing } \\
\text { procedure }\end{array}$ & $\begin{array}{l}\text { Insemination } \\
\text { dose }\end{array}$ & Site of AI & $\begin{array}{l}\text { No. } \\
\text { insem. }\end{array}$ & $\begin{array}{l}\text { AI per } \\
\text { oestrous }\end{array}$ & $\begin{array}{l}\% \\
\text { Pregnant }\end{array}$ & $\begin{array}{l}\text { Embryos/ } \\
\text { Piglets (E/P) }\end{array}$ & Conclusion & Comment & Reference \\
\hline $\begin{array}{l}\text { L-EY, OEP, } \\
\text { Glycerol }\end{array}$ & & $\begin{array}{l}\text { Water bath, } \\
52^{\circ} \mathrm{C}, 52 \mathrm{~s}\end{array}$ & $6 \times 10^{9}$ & Cervical & 220 & 1 & $\begin{array}{l}51.4 \% \\
\text { Farrowing } \\
\text { Rate }\end{array}$ & $8.8 \mathrm{P}$ & $\begin{array}{l}\text { Fertilizing } \\
\text { results fort } \\
\text { his method } \\
\text { where } \\
\text { similar to } \\
\text { that of other } \\
\text { reports }\end{array}$ & $\begin{array}{l}\text { Frozen in } \\
5 \mathrm{ml} \\
\text { Macro- } \\
\text { Straws in } \\
\text { batches of } \\
150-300 \\
\text { straws in } \\
\text { controlled- } \\
\text { rate } \\
\text { freezer }\end{array}$ & $\begin{array}{l}\text { Hammit and } \\
\text { Martin } 1989\end{array}$ \\
\hline $\begin{array}{l}\text { L-EY, OEP, } \\
\text { Glycerol }\end{array}$ & $\begin{array}{l}\text { Part of the } \\
\text { semen was } \\
\text { supplement } \\
\text { ed with } \\
\text { seminal } \\
\text { plasma } \\
\text { after } \\
\text { thawing }\end{array}$ & $\begin{array}{l}\text { Water bath, } \\
50^{\circ} \mathrm{C}, 45 \mathrm{~s} \\
\text { for } \\
\text { Macrotubes } \\
\text { or } 39^{\circ} \mathrm{C}, \\
20 \mathrm{~s} \text { for } \\
\text { FlatPack }\end{array}$ & $5 \times 10^{9}$ & Cervical & 110 & $1-2$ & $73 \%$ & $12.0 \mathrm{E}$ & $\begin{array}{l}\text { No } \\
\text { differences } \\
\text { in fertility } \\
\text { were found } \\
\text { due to } \\
\text { packaging, } \\
\text { No. of AI or } \\
\text { thawing } \\
\text { solution }\end{array}$ & $\begin{array}{l}\text { Semen } \\
\text { frozen } \\
\text { either in } \\
5 \mathrm{ml} \\
\text { Macrotube } \\
\text { s or } 2 \mathrm{ml} \\
\text { FlatPack }\end{array}$ & Stampa 1989 \\
\hline
\end{tabular}


$\underline{\text { Review of Literature }}$

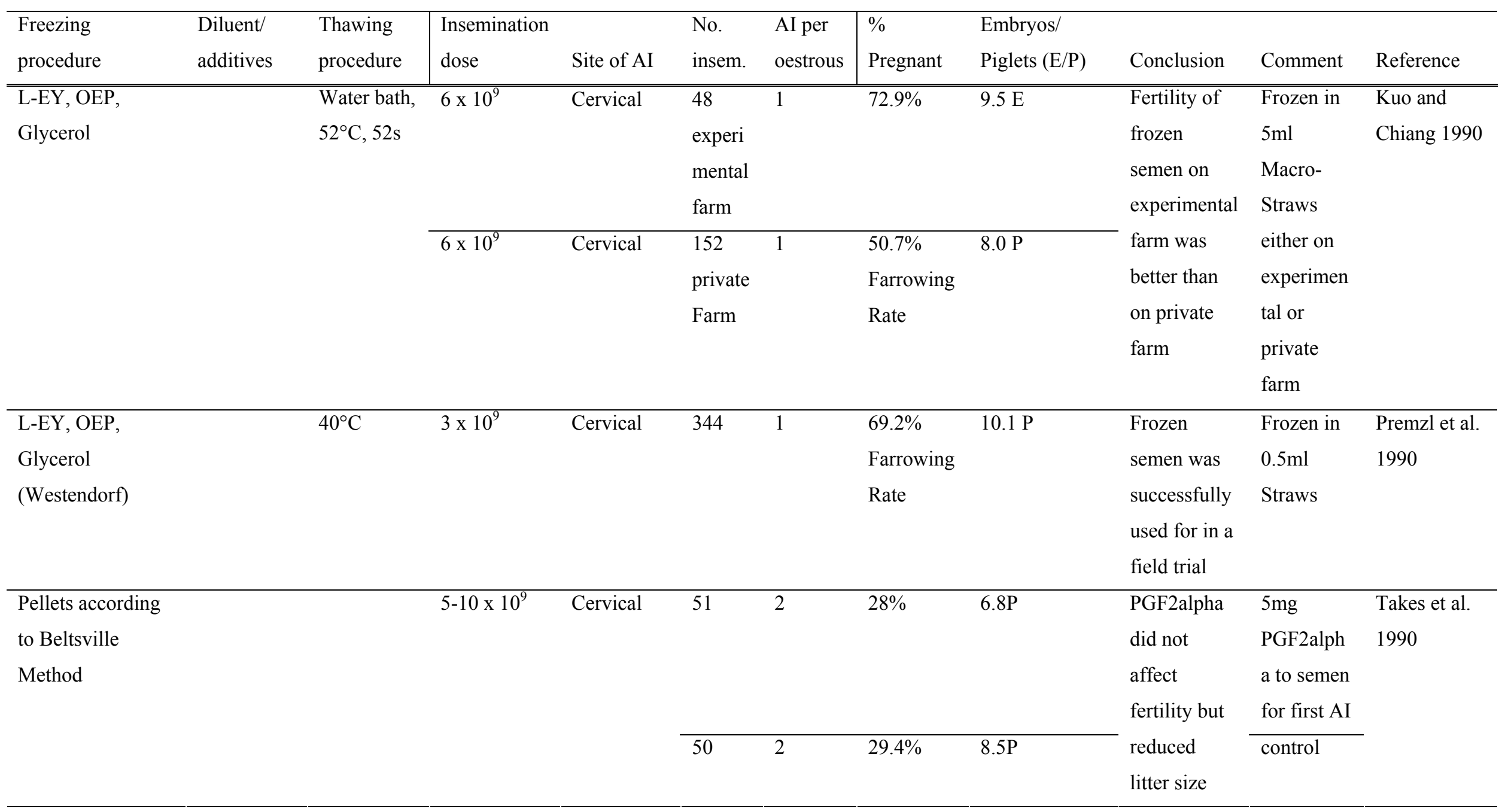


$\underline{\text { Review of Literature }}$

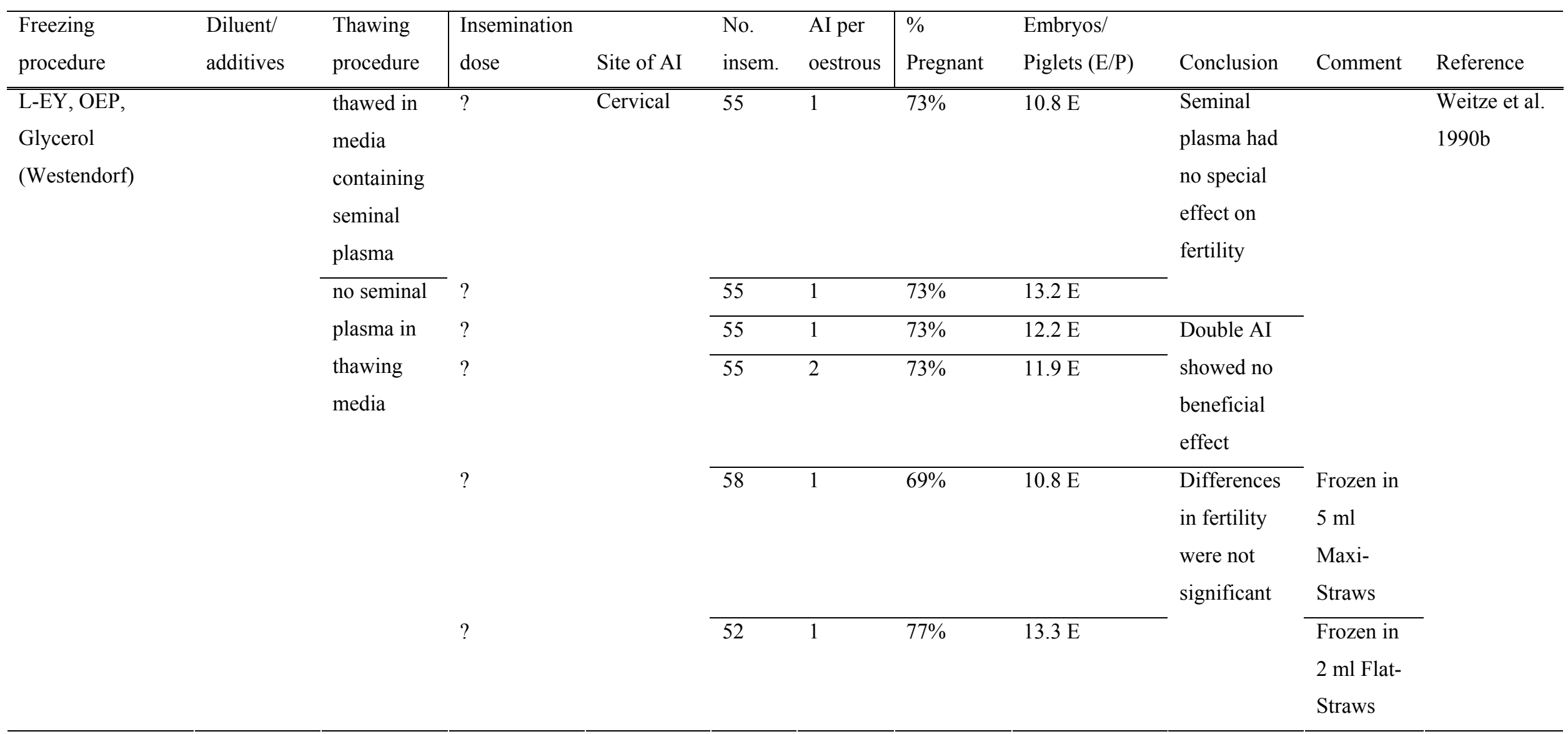


$\underline{\text { Review of Literature }}$

\begin{tabular}{|c|c|c|c|c|c|c|c|c|c|c|c|}
\hline $\begin{array}{l}\text { Freezing } \\
\text { procedure }\end{array}$ & $\begin{array}{l}\text { Diluent/ } \\
\text { additives }\end{array}$ & $\begin{array}{l}\text { Thawing } \\
\text { procedure }\end{array}$ & $\begin{array}{l}\text { Insemination } \\
\text { dose }\end{array}$ & Site of AI & $\begin{array}{l}\text { No. } \\
\text { insem. }\end{array}$ & $\begin{array}{l}\text { AI per } \\
\text { oestrous }\end{array}$ & $\begin{array}{l}\% \\
\text { Pregnant }\end{array}$ & $\begin{array}{l}\text { Embryos/ } \\
\text { Piglets (E/P) }\end{array}$ & Conclusion & Comment & Reference \\
\hline Pellet-Method & Aminoaceti & Dry 50- & $440-60 \times 10^{6}$ & Cervical & "68056 & 1 & $75.5 \%$ & $9.5 \mathrm{P}$ & & Field & $\mathrm{Xu}$ and $\mathrm{Wu}$ \\
\hline Skim Milk, & $\mathrm{c}$ acid, Na- & $60^{\circ} \mathrm{C}$ for & & & & & & & & results & 1990 \\
\hline Lactose, Glucose, & citrate & $30 \mathrm{~s}$ & & & & & & & & from & \\
\hline Egg Yolk, & & & & & & & & & & 1981-1988 & \\
\hline \multirow[t]{16}{*}{ Glycerol } & & & & & & & & & & in PRC & \\
\hline & & & & & 1053 & 1 & $57.7 \%$ & $9.2 \mathrm{P}$ & \multirow{3}{*}{$\begin{array}{l}\text { Double AI } \\
\text { improved } \\
\text { fertility }\end{array}$} & & \\
\hline & & & & & 548 & 2 & $77.0 \%$ & $10.1 \mathrm{P}$ & & & \\
\hline & & & & & & & & & & & \\
\hline & & & $20-45 \times 10^{6}$ & & 96 & 1 & $57.3 \%$ & $9.9 \mathrm{P}$ & \multirow{5}{*}{$\begin{array}{l}\text { Farrowing } \\
\text { rate was } \\
\text { better due to } \\
\text { higher } \\
\text { sperm dose }\end{array}$} & & \\
\hline & & & $40-75 \times 10^{6}$ & & 229 & 1 & $75.1 \%$ & $10.2 \mathrm{P}$ & & & \\
\hline & & & & & & & & & & & \\
\hline & & & & & & & & & & & \\
\hline & & & & & & & & & & & \\
\hline & & & $40-60 \times 10^{6}$ & & 38 & 1 & $76.3 \%$ & $11.0 \mathrm{P}$ & \multirow{7}{*}{$\begin{array}{l}\text { No } \\
\text { differences } \\
\text { in fertility } \\
\text { were found } \\
\text { due to } \\
\text { storage time }\end{array}$} & Semen & \\
\hline & & & & & & & & & & stored for & \\
\hline & & & & & & & & & & 2-3 month & \\
\hline & & & & & 37 & 1 & $78.4 \%$ & $9.9 \mathrm{P}$ & & Semen & \\
\hline & & & & & & & & & & stored for & \\
\hline & & & & & & & & & & $3-8$ & \\
\hline & & & & & & & & & & months & \\
\hline
\end{tabular}


$\underline{\text { Review of Literature }}$

\begin{tabular}{|c|c|c|c|c|c|c|c|c|c|c|c|}
\hline $\begin{array}{l}\text { Freezing } \\
\text { procedure }\end{array}$ & $\begin{array}{l}\text { Diluent/ } \\
\text { additives }\end{array}$ & $\begin{array}{l}\text { Thawing } \\
\text { procedure }\end{array}$ & $\begin{array}{l}\text { Insemination } \\
\text { dose }\end{array}$ & Site of AI & $\begin{array}{l}\text { No. } \\
\text { insem. }\end{array}$ & $\begin{array}{l}\text { AI per } \\
\text { oestrous }\end{array}$ & $\begin{array}{l}\% \\
\text { Pregnant }\end{array}$ & $\begin{array}{l}\text { Embryos/ } \\
\text { Piglets (E/P) }\end{array}$ & Conclusion & Comment & Reference \\
\hline & & & & & 21 & 1 & $81.0 \%$ & $9.2 \mathrm{P}$ & & $\begin{array}{l}\text { Semen } \\
\text { stored for } \\
4 \text { years }\end{array}$ & \\
\hline $\begin{array}{l}\text { L-EY, OEP, } \\
\text { Glycerol }\end{array}$ & & $\begin{array}{l}\text { Water bath } \\
50^{\circ} \mathrm{C}, 40 \mathrm{~s}\end{array}$ & $5 \times 10^{9}$ & Cervical & 13 & 1 & $63 \%$ & $?$ & \multirow{2}{*}{$\begin{array}{l}\text { More ova } \\
\text { were } \\
\text { fertilized } \\
\text { after AI with } \\
\text { semen } \\
\text { frozen in } \\
\text { plastic bags }\end{array}$} & $\begin{array}{l}\text { Frozen in } \\
2.5 \mathrm{ml} \\
\text { Maxi- } \\
\text { straws }\end{array}$ & $\begin{array}{l}\text { Bwanga et } \\
\text { al. 1991b }\end{array}$ \\
\hline $\begin{array}{l}\text { L-EY, OEP, } \\
\text { Glycerol }\end{array}$ & & $\begin{array}{l}\text { Water bath } \\
50^{\circ} \mathrm{C}, 40 \mathrm{~s}\end{array}$ & $5 \times 10^{9}$ & Cervical & 13 & 1 & $75 \%$ & $?$ & & $\begin{array}{l}\text { frozen in } \\
5 \mathrm{ml} \text { plastic } \\
\text { bags }\end{array}$ & \\
\hline $\begin{array}{l}\text { L-EY, OEP, } \\
\text { Glycerol }\end{array}$ & & $\begin{array}{l}\text { Water bath } \\
50^{\circ} \mathrm{C}, 40 \mathrm{~s}\end{array}$ & $4 \times 10^{9}$ & Cervical & 82 & 1 & $\begin{array}{l}61.2 \% \\
\text { fertilized } \\
\text { ova }\end{array}$ & & \multirow{2}{*}{$\begin{array}{l}\text { Flat PVC- } \\
\text { tubes } \\
\text { improved } \\
\text { fertility of } \\
\text { frozen } \\
\text { semen }\end{array}$} & $\begin{array}{l}\text { Frozen in } \\
\text { round } \\
\text { PVC-tubes } \\
(4 \mathrm{ml})\end{array}$ & $\begin{array}{l}\text { Simmet } \\
1993\end{array}$ \\
\hline $\begin{array}{l}\text { L-EY, OEP, } \\
\text { Glycerol }\end{array}$ & & $\begin{array}{l}\text { Water bath } \\
39^{\circ} \mathrm{C}, 15 \mathrm{~s}\end{array}$ & $4 \times 10^{9}$ & Cervical & 81 & 1 & $\begin{array}{l}77.3 \% \\
\text { fertilized } \\
\text { ova }\end{array}$ & & & $\begin{array}{l}\text { Frozen in } \\
\text { flat } \\
\text { rectangula } \\
r \text { cross- } \\
\text { section } \\
\text { PVC-tubes } \\
(2 \mathrm{ml})\end{array}$ & \\
\hline
\end{tabular}




\begin{tabular}{|c|c|c|c|c|c|c|c|c|c|c|c|}
\hline $\begin{array}{l}\text { Freezing } \\
\text { procedure }\end{array}$ & $\begin{array}{l}\text { Diluent/ } \\
\text { additives }\end{array}$ & $\begin{array}{l}\text { Thawing } \\
\text { procedure }\end{array}$ & $\begin{array}{l}\text { Insemination } \\
\text { dose }\end{array}$ & Site of AI & $\begin{array}{l}\text { No. } \\
\text { insem. }\end{array}$ & $\begin{array}{l}\text { AI per } \\
\text { oestrous }\end{array}$ & $\begin{array}{l}\% \\
\text { Pregnant }\end{array}$ & $\begin{array}{l}\text { Embryos/ } \\
\text { Piglets (E/P) }\end{array}$ & Conclusion & Comment & Reference \\
\hline \multirow{5}{*}{$\begin{array}{l}\text { L-EY, OEP, } \\
\text { Glycerol }\end{array}$} & & ? & $5 \times 10^{9}$ & Cervical & 19 & 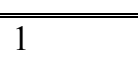 & $84.2 \%$ & $91.8 \%$ viable & \multirow{5}{*}{$\begin{array}{l}\text { AI after } \\
\text { Ovulation } \\
\text { decreased } \\
\text { embryo } \\
\text { quality }\end{array}$} & AI 6h & \multirow{5}{*}{$\begin{array}{l}\text { Bertani et al. } \\
1996\end{array}$} \\
\hline & & & & & & & & $\mathrm{E}$ & & before & \\
\hline & & & & & & & & & & ovulation & \\
\hline & & $?$ & $5 \times 10^{9}$ & Cervical & 19 & 1 & $78.9 \%$ & $84.6 \%$ viable & & AI $6 \mathrm{~h}$ after & \\
\hline & & & & & & & & $\mathrm{E}$ & & ovulation & \\
\hline \multirow[t]{4}{*}{ Pellet-Method } & $5 \mathrm{mg}$ P4 & $?$ & $6 \times 10^{9}$ & Cervical & 13 & 2 & $53.8 \%$ & $5.71 \mathrm{E}$ & \multirow{9}{*}{$\begin{array}{l}\text { Addition of } \\
\text { P4 to semen } \\
\text { had no effect }\end{array}$} & & Castaneda \\
\hline & added & & & & & & & & & & Moreno et \\
\hline & before & & & & & & & & & & al. 1996 \\
\hline & freezing & & & & & & & & & & \\
\hline \multirow[t]{3}{*}{ Pellet-Method } & $5 \mathrm{mg}$ P4 & $?$ & $6 \times 10^{9}$ & Cervical & 13 & 2 & $46.1 \%$ & $6.83 \mathrm{E}$ & & & \\
\hline & added after & & & & & & & & & & \\
\hline & freezing & & & & & & & & & & \\
\hline \multirow[t]{2}{*}{ Pellet-Method } & No P4 & $?$ & $6 \times 10^{9}$ & Cervical & 13 & 2 & $61.5 \%$ & $8.25 \mathrm{E}$ & & Control & \\
\hline & added & & & & & & & & & & \\
\hline \multirow{4}{*}{$\begin{array}{l}\text { L-EY, OEP, } \\
\text { Glycerol }\end{array}$} & & $42^{\circ} \mathrm{C}, 45 \mathrm{~s}$ & $5 \times 10^{9}$ & Cervical & 69 & 2 & $88.4 \%$ & $9.9 \mathrm{P}$ & \multirow{4}{*}{$\begin{array}{l}\text { PGF2a did } \\
\text { not } \\
\text { influence } \\
\text { farrowing }\end{array}$} & Frozen in & \multirow{4}{*}{$\begin{array}{l}\text { Gil et al. } \\
1996\end{array}$} \\
\hline & & & & & & & Farrowing & & & $5 \mathrm{ml}$ & \\
\hline & & & & & & & rate & & & Macrotube & \\
\hline & & & & & & & & & & ; & \\
\hline
\end{tabular}


$\underline{\text { Review of Literature }}$

\begin{tabular}{|c|c|c|c|c|c|c|c|c|c|c|c|}
\hline $\begin{array}{l}\text { Freezing } \\
\text { procedure }\end{array}$ & $\begin{array}{l}\text { Diluent/ } \\
\text { additives }\end{array}$ & $\begin{array}{l}\text { Thawing } \\
\text { procedure }\end{array}$ & $\begin{array}{l}\text { Insemination } \\
\text { dose }\end{array}$ & Site of AI & $\begin{array}{l}\text { No. } \\
\text { insem. }\end{array}$ & $\begin{array}{l}\text { AI per } \\
\text { oestrous }\end{array}$ & $\begin{array}{l}\% \\
\text { Pregnant }\end{array}$ & $\begin{array}{l}\text { Embryos/ } \\
\text { Piglets (E/P) }\end{array}$ & Conclusion & Comment & Reference \\
\hline $\begin{array}{l}\text { L-EY, OEP, } \\
\text { Glycerol }\end{array}$ & & & $5 \times 10^{9}$ & Cervical & 59 & 2 & $\begin{array}{l}86.4 \% \\
\text { Farrowing } \\
\text { rate }\end{array}$ & $111.2 \mathrm{P}$ & $\begin{array}{l}\text { rate but } \\
\text { reduced } \\
\text { litter size }\end{array}$ & $\begin{array}{l}\text { Frozen in } \\
5 \mathrm{ml} \\
\text { Macrotube } \\
\text {; } 5 \mathrm{mg} \text { of } \\
\text { PGF2alph } \\
\text { a were } \\
\text { added to } \\
\text { the semen } \\
\text { dose }\end{array}$ & \\
\hline $\begin{array}{l}\text { L-EY, OEP, } \\
\text { Glycerol }\end{array}$ & & $50^{\circ} \mathrm{C} 25 \mathrm{~s}$ & $5 \times 10^{9}$ & Cervical & 16 & 2 & $64.3 \%$ & $9.9 \mathrm{E}$ & $\begin{array}{l}\text { Cochette } \\
\text { showed } \\
\text { better post- }\end{array}$ & $\begin{array}{l}\text { Frozen in } \\
5 \mathrm{ml} \text { Maxi- } \\
\text { Straws }\end{array}$ & $\begin{array}{l}\text { Rodriguez- } \\
\text { Martinez et } \\
\text { al. } 1996\end{array}$ \\
\hline $\begin{array}{l}\text { L-EY, OEP, } \\
\text { Glycerol }\end{array}$ & & $50^{\circ} \mathrm{C} 25 \mathrm{~s}$ & $5 \times 10^{9}$ & Cervical & 16 & 2 & $62.5 \%$ & $9.4 \mathrm{E}$ & $\begin{array}{l}\text { thaw } \\
\text { motility but } \\
\text { fertility } \\
\text { results were } \\
\text { not different }\end{array}$ & $\begin{array}{l}\text { Frozen in } \\
\text { plastic } \\
\text { Cochettes }\end{array}$ & \\
\hline
\end{tabular}


$\underline{\text { Review of Literature }}$

\begin{tabular}{|c|c|c|c|c|c|c|c|c|c|c|c|}
\hline $\begin{array}{l}\text { Freezing } \\
\text { procedure }\end{array}$ & $\begin{array}{l}\text { Diluent/ } \\
\text { additives }\end{array}$ & $\begin{array}{l}\text { Thawing } \\
\text { procedure }\end{array}$ & $\begin{array}{l}\text { Insemination } \\
\text { dose }\end{array}$ & Site of AI & $\begin{array}{l}\text { No. } \\
\text { insem. }\end{array}$ & $\begin{array}{l}\text { AI per } \\
\text { oestrous }\end{array}$ & $\begin{array}{l}\% \\
\text { Pregnant }\end{array}$ & $\begin{array}{l}\text { Embryos/ } \\
\text { Piglets (E/P) }\end{array}$ & Conclusion & Comment & Reference \\
\hline $\begin{array}{l}\text { Huelsenberg- } \\
\text { Method }\end{array}$ & & & & & 21 & & $47.6 \%$ & $9.8 \mathrm{P}$ & $\begin{array}{l}\text { no } \\
\text { differences } \\
\text { were found } \\
\text { to new } \\
\text { extender } \\
\text { type }\end{array}$ & Control & $\begin{array}{l}\text { Samoulidis } \\
\text { et al. } 1996\end{array}$ \\
\hline $\begin{array}{l}\text { L-EY, OEP, 2\% } \\
\text { Glycerol }\end{array}$ & & $37^{\circ} \mathrm{C}, 3 \mathrm{~min}$ & $30 \times 10^{6}$ & $\begin{array}{l}\text { Fallopian } \\
\text { tube }\end{array}$ & 12 & 1 & $\begin{array}{l}25 \% \mathrm{PR} \\
8.3 \% \mathrm{FR}\end{array}$ & $2 \mathrm{P}$ & $\begin{array}{l}\text { AI of } \\
\text { epididymal } \\
\text { sperm in } \\
\text { fallopian } \\
\text { tube was } \\
\text { successful }\end{array}$ & $\begin{array}{l}\text { Epididyma } \\
1 \text { sperm/ } \\
\text { Epididymi } \\
\text { s stored at } \\
4^{\circ} \text { for } 24 \mathrm{~h}\end{array}$ & $\begin{array}{l}\text { Kikuchi et } \\
\text { al. } 1999\end{array}$ \\
\hline $\begin{array}{l}\text { CIAP freezing } \\
\text { method }\end{array}$ & & & & & 298 & $1-2$ & $76.2 \%$ & $9.4 \mathrm{P}$ & $\begin{array}{l}\text { No } \\
\text { differences } \\
\text { in fertility } \\
\text { were found } \\
\text { compared to } \\
\text { AI with } \\
\text { fresh semen }\end{array}$ & $\begin{array}{l}\text { Field } \\
\text { results of a } \\
\text { AI Station } \\
1995 \\
\text { Field } \\
\text { results of a } \\
\text { AI Station } \\
1996\end{array}$ & $\begin{array}{l}\text { Thilmant } \\
1999\end{array}$ \\
\hline
\end{tabular}


$\underline{\text { Review of Literature }}$

\begin{tabular}{|c|c|c|c|c|c|c|c|c|c|c|c|}
\hline $\begin{array}{l}\text { Freezing } \\
\text { procedure }\end{array}$ & $\begin{array}{l}\text { Diluent/ } \\
\text { additives }\end{array}$ & $\begin{array}{l}\text { Thawing } \\
\text { procedure }\end{array}$ & $\begin{array}{l}\text { Insemination } \\
\text { dose }\end{array}$ & Site of AI & $\begin{array}{l}\text { No. } \\
\text { insem. }\end{array}$ & $\begin{array}{l}\text { AI per } \\
\text { oestrous }\end{array}$ & $\begin{array}{l}\% \\
\text { Pregnant }\end{array}$ & $\begin{array}{l}\text { Embryos/ } \\
\text { Piglets (E/P) }\end{array}$ & Conclusion & Comment & Reference \\
\hline $\begin{array}{l}\text { L-EY, OEP, } \\
\text { Glycerol }\end{array}$ & & & $4 \times 10^{9}$ & cervical & 193 & $2-3$ & $74 \%$ & $9.97 \mathrm{P}$ & $\begin{array}{l}\text { Fertility trial } \\
\text { to set up } \\
\text { European } \\
\text { pig } \\
\text { cryobank } \\
\text { was } \\
\text { successful }\end{array}$ & & $\begin{array}{l}\text { Bussiere et } \\
\text { al. } 2000\end{array}$ \\
\hline $\begin{array}{l}\text { L-EY, OEP, } \\
\text { Glycerol }\end{array}$ & & $\begin{array}{l}\text { Water bath, } \\
50^{\circ} \mathrm{C} ; 13 \mathrm{~s}\end{array}$ & $5 \times 10^{9}$ & Cervical & 227 & 2 & $75 \%$ & $10.6 \mathrm{P}$ & $\begin{array}{l}\text { Semen } \\
\text { frozen in } \\
\text { FlatPacks } \\
\text { can } \\
\text { successfully } \\
\text { be exported }\end{array}$ & $\begin{array}{l}\text { Semen } \\
\text { frozen in } \\
\text { FlatPacks } \\
\text { and } \\
\text { exported } \\
\text { to Taiwan } \\
\text { or Ireland }\end{array}$ & $\begin{array}{l}\text { Eriksson and } \\
\text { Rodriguez- } \\
\text { Martinez } \\
2000 \mathrm{a}\end{array}$ \\
\hline \multirow[t]{2}{*}{$\begin{array}{l}\text { L-EY, OEP, } \\
\text { Glycerol }\end{array}$} & & $\begin{array}{l}\text { Water bath, } \\
50^{\circ} \mathrm{C} ; 20 \mathrm{~s}\end{array}$ & $3 \times 10^{9}$ & Cervical & 20 & $1-2$ & 60 & $9.6 \mathrm{E}$ & \multirow{2}{*}{$\begin{array}{l}\text { No } \\
\text { differences } \\
\text { in fertility } \\
\text { were found } \\
\text { due to } \\
\text { semen } \\
\text { packaging }\end{array}$} & $\begin{array}{l}\text { Frozen in } \\
5 \mathrm{ml} \text { Maxi- } \\
\text { straws }\end{array}$ & $\begin{array}{l}\text { Eriksson and } \\
\text { Rodriguez- } \\
\text { Martinez }\end{array}$ \\
\hline & & $\begin{array}{l}\text { Water bath, } \\
50^{\circ} \mathrm{C} ; 40 \mathrm{~s}\end{array}$ & $3 \times 10^{9}$ & Cervical & 20 & $1-2$ & 65 & $9.7 \mathrm{E}$ & & $\begin{array}{l}\text { Frozen in } \\
5 \mathrm{ml} \text { plastic } \\
\text { film } \\
\text { cochettes }\end{array}$ & $2000 \mathrm{~b}$ \\
\hline
\end{tabular}


$\underline{\text { Review of Literature }}$

\begin{tabular}{|c|c|c|c|c|c|c|c|c|c|c|c|}
\hline $\begin{array}{l}\text { Freezing } \\
\text { procedure }\end{array}$ & $\begin{array}{l}\text { Diluent/ } \\
\text { additives }\end{array}$ & $\begin{array}{l}\text { Thawing } \\
\text { procedure }\end{array}$ & $\begin{array}{l}\text { Insemination } \\
\text { dose }\end{array}$ & Site of AI & $\begin{array}{l}\text { No. } \\
\text { insem. }\end{array}$ & $\begin{array}{l}\text { AI per } \\
\text { oestrous }\end{array}$ & $\begin{array}{l}\% \\
\text { Pregnant }\end{array}$ & $\begin{array}{l}\text { Embryos/ } \\
\text { Piglets (E/P) }\end{array}$ & Conclusion & Comment & Reference \\
\hline $\begin{array}{l}\text { L-EY, OEP, } \\
\text { Glycerol }\end{array}$ & $\begin{array}{l}\text { Thawing } \\
\text { diluent } \\
\text { consisted } \\
\text { of } 20 \% \mathrm{EY} \text {, } \\
80 \% \\
\text { Lactose, } \\
400 \text { I.U. } \\
\text { Catalase/ml }\end{array}$ & $\begin{array}{l}\text { Water bath, } \\
50^{\circ} \mathrm{C} ; 45 \mathrm{~s}\end{array}$ & $?$ & & 47 & 1 & $\begin{array}{l}86.4 \\
\text { Farrowing } \\
\text { rate }\end{array}$ & $10.1 \mathrm{P}$ & $\begin{array}{l}\text { EY and } \\
\text { Catalase } \\
\text { improved } \\
\text { post-thaw } \\
\text { motility and } \\
\text { showed } \\
\text { successful } \\
\text { fertilization }\end{array}$ & $\begin{array}{l}\text { Frozen in } \\
5 \mathrm{ml} \\
\text { Maxi- } \\
\text { Straws }\end{array}$ & $\begin{array}{l}\text { Kuo and } \\
\text { Huang } 2000\end{array}$ \\
\hline $\begin{array}{l}\text { CIAP freezing } \\
\text { method }\end{array}$ & & $\begin{array}{l}\text { Water bath, } \\
55^{\circ} \mathrm{C}, 12 \mathrm{~s}\end{array}$ & $\begin{array}{l}3.8 \times 10^{9} \text { in } \\
5 \text { medium } \\
\text { straws } \\
3.8 \times 10^{9} \text { in } \\
10 \text { mini } \\
\text { straws } \\
1.9 \times 10^{9} \text { in } \\
5 \text { mini } \\
\text { straws }\end{array}$ & & 22 & & $86.4 \%$ & $11.1 \mathrm{P}$ & $\begin{array}{l}\text { Treatments } \\
\text { showed no } \\
\text { significant } \\
\text { differences }\end{array}$ & & $\begin{array}{l}\text { Thilmant } \\
2001\end{array}$ \\
\hline
\end{tabular}


$\underline{\text { Review of Literature }}$

\begin{tabular}{|c|c|c|c|c|c|c|c|c|c|c|c|}
\hline $\begin{array}{l}\text { Freezing } \\
\text { procedure }\end{array}$ & $\begin{array}{l}\text { Diluent/ } \\
\text { additives }\end{array}$ & $\begin{array}{l}\text { Thawing } \\
\text { procedure }\end{array}$ & $\begin{array}{l}\text { Insemination } \\
\text { dose }\end{array}$ & Site of AI & $\begin{array}{l}\text { No. } \\
\text { insem. }\end{array}$ & $\begin{array}{l}\text { AI per } \\
\text { oestrous }\end{array}$ & $\begin{array}{l}\% \\
\text { Pregnant }\end{array}$ & $\begin{array}{l}\text { Embryos/ } \\
\text { Piglets (E/P) }\end{array}$ & Conclusion & Comment & Reference \\
\hline $\begin{array}{l}\text { L-EY, OEP, 3\% } \\
\text { Glycerol }\end{array}$ & & $\begin{array}{l}\text { Water bath, } \\
50^{\circ} \mathrm{C}, 13 \mathrm{~s}\end{array}$ & $5 \times 10^{9}$ & Cervical & 352 & 2 & $72 \%$ & $10.7 \mathrm{P}$ & $\begin{array}{l}\text { Freezing in } \\
\text { FlatPack } \\
\text { may be a } \\
\text { reliable } \\
\text { alternative } \\
\text { for the } \\
\text { freezing/tha } \\
\text { wing of boar } \\
\text { semen under } \\
\text { commercial } \\
\text { AI cond. }\end{array}$ & $\begin{array}{l}\text { Frozen in } \\
5 \mathrm{ml} \\
\text { FlatPacks }\end{array}$ & $\begin{array}{l}\text { Eriksson et } \\
\text { al. } 2002\end{array}$ \\
\hline$?$ & & & & & & & & & $\begin{array}{l}\text { Freezing } \\
\text { semen in } \\
\text { magnetic } \\
\text { field } \\
\text { improved } \\
\text { sperm } \\
\text { quality }\end{array}$ & $\begin{array}{l}\text { Frozen in } \\
\text { Maxi- } \\
\text { straws in } \\
\text { magnetic- } \\
\text { field }\end{array}$ & $\begin{array}{l}\text { Masuda et } \\
\text { al. } 2002\end{array}$ \\
\hline $\begin{array}{l}\text { L-EY, OEP, } \\
\text { Glycerol, 10min } \\
\text { in LN2 vapour }\end{array}$ & & $\begin{array}{l}\text { Water bath, } \\
70^{\circ} \mathrm{C}, 6 \mathrm{~s}\end{array}$ & & Cervical & 12 & & $25 \%$ & $7,3 \mathrm{P}$ & $\begin{array}{l}\text { AI of frozen } \\
\text { semen was } \\
\text { successful }\end{array}$ & $\begin{array}{l}0.5 \text { French } \\
\text { straws }\end{array}$ & $\begin{array}{l}\text { Nizanski and } \\
\text { Bielas } 2003\end{array}$ \\
\hline
\end{tabular}


$\underline{\text { Review of Literature }}$

\begin{tabular}{|c|c|c|c|c|c|c|c|c|c|c|c|}
\hline $\begin{array}{l}\text { Freezing } \\
\text { procedure }\end{array}$ & $\begin{array}{l}\text { Diluent/ } \\
\text { additives }\end{array}$ & $\begin{array}{l}\text { Thawing } \\
\text { procedure }\end{array}$ & $\begin{array}{l}\text { Insemination } \\
\text { dose }\end{array}$ & Site of AI & $\begin{array}{l}\text { No. } \\
\text { insem. }\end{array}$ & $\begin{array}{l}\text { AI per } \\
\text { oestrous }\end{array}$ & $\begin{array}{l}\% \\
\text { Pregnant }\end{array}$ & $\begin{array}{l}\text { Embryos/ } \\
\text { Piglets (E/P) }\end{array}$ & Conclusion & Comment & Reference \\
\hline $\begin{array}{l}\text { L-EY, OEP, } \\
\text { Glycerol+BF5, } \\
\text { Pellets }\end{array}$ & & & $6 \times 10^{9}$ & cervical & & 2 & $88.4 \%$ & Fertilized eggs & $\begin{array}{l}\text { Transgenes } \\
\text { of parents } \\
\text { were } \\
\text { successfully } \\
\text { transmitted } \\
\text { to piglets }\end{array}$ & $\begin{array}{l}\text { Several } \\
\text { litters } \\
\text { born! }\end{array}$ & $\begin{array}{l}\text { Sommer et } \\
\text { al. } 2002\end{array}$ \\
\hline \multirow[t]{3}{*}{ Glycerol } & & & $6 \times 10^{9}$ & Cervical & 30 & 1 & $\begin{array}{l}83.3 \% \\
\text { Farrowing } \\
\text { rate }\end{array}$ & $8.1 \mathrm{P}$ & \multirow{4}{*}{$\begin{array}{l}\text { MR-A } \\
\text { THAW and } \\
\text { DUI can } \\
\text { improve } \\
\text { field results } \\
\text { due to better } \\
\text { use of } \\
\text { ejaculates } \\
\text { a dose of } \\
250 \times 10^{6} \\
\text { sperm can } \\
\text { be used with }\end{array}$} & \multirow{3}{*}{$\begin{array}{l}\text { Sperm } \\
\text { thawed in } \\
\text { MR-A } \\
\text { THAW } \\
\text { solution }\end{array}$} & \multirow[t]{3}{*}{$\begin{array}{l}\text { De Alba et } \\
\text { al. } 2003\end{array}$} \\
\hline & & & $6 \times 10^{9}$ & DUI & 45 & 1 & $\begin{array}{l}12.1 \\
\text { Farrowing } \\
\text { rate }\end{array}$ & $9.0 \mathrm{P}$ & & & \\
\hline & & & $3 \times 10^{9}$ & DUI & 45 & & $\begin{array}{l}81.8 \\
\text { Farrowing } \\
\text { rate }\end{array}$ & $8.0 \mathrm{P}$ & & & \\
\hline \multirow[t]{2}{*}{ Glycerol } & & $?$ & $1 \times 10^{9}$ & DUI & 45 & 2 & $\begin{array}{l}34.7 \\
\text { Farrowing } \\
\text { rate }\end{array}$ & $8.9 \mathrm{P}$ & & $\begin{array}{l}\text { Frozen in } \\
0.5 \text { French } \\
\text { straws }\end{array}$ & $\begin{array}{l}\text { Bathgate et } \\
\text { al. } 2003\end{array}$ \\
\hline & & $?$ & $250 \times 10^{6}$ & DUI & 45 & 2 & $\begin{array}{l}2.9 \\
\text { Farrowing } \\
\text { rate }\end{array}$ & $7.2 \mathrm{P}$ & $\begin{array}{l}\text { be used with } \\
\text { DUI without } \\
\text { reduction of }\end{array}$ & & \\
\hline
\end{tabular}


$\underline{\text { Review of Literature }}$

\begin{tabular}{|c|c|c|c|c|c|c|c|c|c|c|c|}
\hline $\begin{array}{l}\text { Freezing } \\
\text { procedure }\end{array}$ & $\begin{array}{l}\text { Diluent/ } \\
\text { additives }\end{array}$ & $\begin{array}{l}\text { Thawing } \\
\text { procedure }\end{array}$ & $\begin{array}{l}\text { Insemination } \\
\text { dose }\end{array}$ & Site of AI & $\begin{array}{l}\text { No. } \\
\text { insem. }\end{array}$ & $\begin{array}{l}\text { AI per } \\
\text { oestrous }\end{array}$ & $\begin{array}{l}\% \\
\text { Pregnant }\end{array}$ & $\begin{array}{l}\text { Embryos/ } \\
\text { Piglets (E/P) }\end{array}$ & Conclusion & Comment & Reference \\
\hline & & ? & $62.5 \times 10^{6}$ & בDUI & 45 & 2 & $\begin{array}{l}7.1 \\
\text { Farrowing } \\
\text { rate }\end{array}$ & $7.3 \mathrm{P}$ & Fertility & & \\
\hline $\begin{array}{l}\text { L-EY, OEP, } \\
\text { Glycerol }\end{array}$ & & & $6 \times 10^{9}$ & Cervical & 33 & 1 & $75.8 \%$ & $9.6 \mathrm{P}$ & $\begin{array}{l}\text { Application } \\
\text { of DUI }\end{array}$ & Timed OV & $\begin{array}{l}\text { Roca et al. } \\
2003\end{array}$ \\
\hline $\begin{array}{l}\text { L-EY, OEP, } \\
\text { Glycerol }\end{array}$ & & & $1 \times 10^{9}$ & DUI & 49 & 1 & $\begin{array}{l}77.6 \% \\
\text { Farrowing } \\
\text { rate }\end{array}$ & $9.31 \mathrm{P}$ & $\begin{array}{l}\text { provides } \\
\text { acceptable } \\
\text { fertility in }\end{array}$ & Timed OV & \\
\hline $\begin{array}{l}\text { L-EY, OEP, } \\
\text { Glycerol }\end{array}$ & & & $1 \times 10^{9}$ & DUI & 40 & 2 & $\begin{array}{l}70 \% \\
\text { Farrowing } \\
\text { rate }\end{array}$ & $9.25 \mathrm{P}$ & $\begin{array}{l}\text { weaned } \\
\text { sows using a } \\
\text { relatively } \\
\text { low number } \\
\text { of frozen- } \\
\text { thawed } \\
\text { spermatozoa }\end{array}$ & $\begin{array}{l}\text { Spontaneo } \\
\text { us OV }\end{array}$ & \\
\hline $\begin{array}{l}\text { L-EY, Glycerol; } \\
\text { unique freezing } \\
\text { technology in } \\
\text { liquid to }-25^{\circ} \mathrm{C} \\
\text { then plunged in } \\
\mathrm{LN} 2\end{array}$ & & $\begin{array}{l}\text { Waterbath, } \\
45 \mathrm{~s} \text { at room } \\
\text { temperature } \\
\text {, then } 5 \mathrm{~min} \\
\text { at } 37^{\circ} \mathrm{C}\end{array}$ & $3 \times 10^{9}$ & Cervical & 4 & 2 & $50 \%$ & $7 \mathrm{P}$ & $\begin{array}{l}\text { New } \\
\text { freezing } \\
\text { technology } \\
\text { could } \\
\text { successfully } \\
\text { be applied }\end{array}$ & $\begin{array}{l}\text { Spontaneo } \\
\text { us OV; } \\
\text { only one } \\
\text { of two } \\
\text { boars sired } \\
\text { litter }\end{array}$ & $\begin{array}{l}\text { Goolsby et } \\
\text { al. } 2004\end{array}$ \\
\hline
\end{tabular}


$\underline{\text { Review of Literature }}$

\begin{tabular}{|c|c|c|c|c|c|c|c|c|c|c|c|}
\hline $\begin{array}{l}\text { Freezing } \\
\text { procedure }\end{array}$ & $\begin{array}{l}\text { Diluent/ } \\
\text { additives }\end{array}$ & $\begin{array}{l}\text { Thawing } \\
\text { procedure }\end{array}$ & $\begin{array}{l}\text { Insemination } \\
\text { dose }\end{array}$ & Site of AI & $\begin{array}{l}\text { No. } \\
\text { insem. }\end{array}$ & $\begin{array}{l}\text { AI per } \\
\text { oestrous }\end{array}$ & $\begin{array}{l}\% \\
\text { Pregnant }\end{array}$ & $\begin{array}{l}\text { Embryos/ } \\
\text { Piglets (E/P) }\end{array}$ & Conclusion & Comment & Reference \\
\hline$\overline{\mathrm{L} \text { L-EY, OEP, }}$ & & Water bath, & $5 \times 10^{9}$ & Cervical & 9 & 1 & $88.9 \%$ & $16.2 \mathrm{E}$ & $\begin{array}{l}\text { Increased } \\
\text { holding time } \\
\text { did not } \\
\text { decrease } \\
\text { Pregnancy- } \\
\text { Rate but } \\
\text { decreased } \\
\text { the number } \\
\text { of embryos }\end{array}$ & $3 \mathrm{~h}$ & Guthrie and \\
\hline \multirow[t]{13}{*}{ Glycerol } & & $50^{\circ} \mathrm{C} ; 40 \mathrm{~s}$ & & & & & & & \multirow{13}{*}{$\begin{array}{l}\text { holding time } \\
\text { did not } \\
\text { decrease } \\
\text { Pregnancy- } \\
\text { Rate but } \\
\text { decreased } \\
\text { the number } \\
\text { of embryos }\end{array}$} & Holding in & \multirow[t]{13}{*}{ Welch 2005} \\
\hline & & & & & & & & & & BTS & \\
\hline & & & & & 7 & 1 & $57.1 \%$ & $13.1 \mathrm{E}$ & & $3 \mathrm{~h}$ holding & \\
\hline & & & & & & & & & & & \\
\hline & & & & & & & & & & Androhep & \\
\hline & & & & & & & & & & Plus & \\
\hline & & & & & 8 & 1 & $50.0 \%$ & $10.9 \mathrm{E}$ & & $24 \mathrm{~h}$ & \\
\hline & & & & & & & & & & holding in & \\
\hline & & & & & & & & & & BTS & \\
\hline & & & & & 7 & 1 & $57.1 \%$ & $6.7 \mathrm{E}$ & & $24 \mathrm{~h}$ & \\
\hline & & & & & & & & & & holding in & \\
\hline & & & & & & & & & & Androhep & \\
\hline & & & & & & & & & & Plus & \\
\hline \multirow{7}{*}{$\begin{array}{l}\text { L-EY, OEP, } \\
\text { Glycerol }\end{array}$} & & $37^{\circ} \mathrm{C} ; 20 \mathrm{~s}$ & $1 \times 10^{9}$ & DUI & 50 & 2 & $42 \% \mathrm{FR}$ & $8.3 \mathrm{P}$ & \multirow{7}{*}{$\begin{array}{l}\text { Increasing } \\
\text { AI-Dose } \\
\text { improved } \\
\text { fertility } \\
\text { results in } \\
\text { pre- and } \\
\text { peri- }\end{array}$} & AI pre- & \multirow{7}{*}{$\begin{array}{l}\text { Bolarin et al. } \\
2006\end{array}$} \\
\hline & & & & & & & & & & ovulatory & \\
\hline & & & $1 \times 10^{9}$ & DUI & 94 & 2 & $83 \%$ FR & $9.4 \mathrm{P}$ & & AI peri- & \\
\hline & & & & & & & & & & ovulatory & \\
\hline & & & $1 \times 10^{9}$ & DUI & 35 & 2 & $31.4 \%$ FR & $7.3 \mathrm{P}$ & & AI post- & \\
\hline & & & & & & & & & & ovulatory & \\
\hline & & & $2 \times 10^{9}$ & DUI & 71 & 2 & $70 \% \mathrm{FR}$ & $9.38 \mathrm{P}$ & & & \\
\hline
\end{tabular}


$\underline{\text { Review of Literature }}$

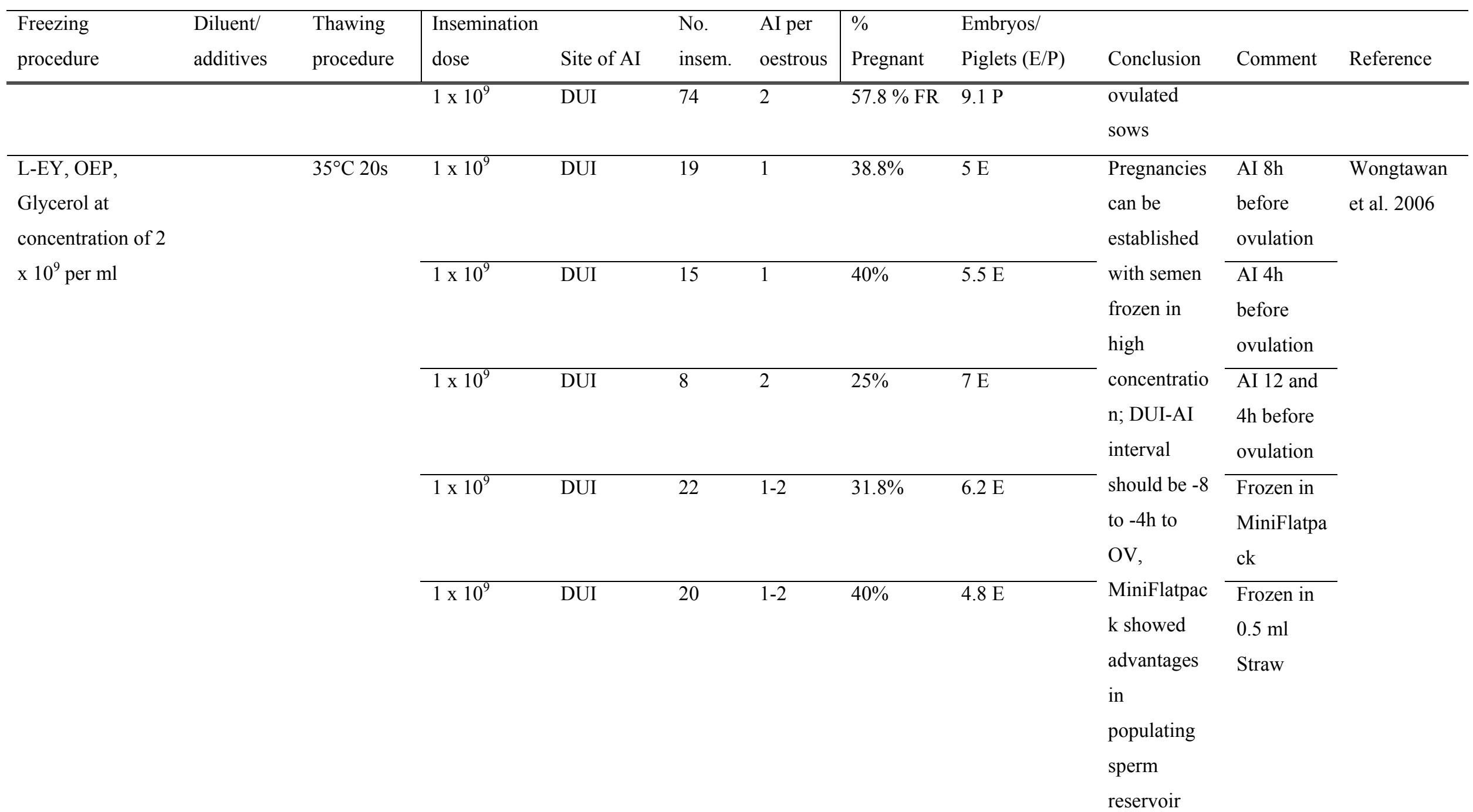




\subsection{Strains for boar spermatozoa during cryopreservation}

Except in bulls and with surgical insemination (Polge et al. 1970) fertility results after AI with frozen semen have never reached to level for AI with fresh semen. According to Watson (2000) a combination of a lowered viability of the sperm and an impaired function of the surviving population are reasons for diminished fertility. The number of fertile spermatozoa, regarding to sperm motility and acrosome integrity, is about 50\% lower in frozen/thawed as compared to fresh semen (Crabo 1991, Watson 2000). In addition there is an absolute loss of sperm cells during processing for cryo-preservation (Schrader 1976), and the number of available semen portions per ejaculate is further decreased. Cryo-preservation of boar semen is associated with different physical and chemical insults to spermatozoa, such as cold shock, osmotic stress, intracellular ice crystal formation and cryoprotectant intoxication during the freezing process (Mazur 1984).

At present, it is generally accepted that the consequences of sperm cryo-injury are impaired transport and poor survival in the female reproductive tract (Salamon and Maxwell 1995). When the interval between insemination of frozen/thawed spermatozoa and ovulation is reduced, fertilisation increases (Parrish and Foote 1986, Kemp and Soede 1997), supporting the hypothesis that sublethal cryo-damage is an effect of the freezing/thawing procedure.

\subsubsection{Effect of cryopreservation on sperm cell organelles}

Sperm Membrane

Sperm organelles are enveloped by a system of membranes. They are particularly vulnerable during cryopreservation, including the plasma membrane, the outer acrosomal membrane and mitochondrial membranes (Hammerstedt et al. 1990, Parks and Graham 1992a, Watson 1995).

Despite doubling the number of sperm (Pursel and Johnson 1975a) insemination with frozen/thawed boar semen reduces both the farrowing rate and the litter size (Johnson et al. 1981). However, the fertility of such semen is not correlated with sperm motility, and is only partly correlated with acrosomal integrity (Wilmut and 
Polge 1977). Loss of function may therefore be due to changes in the plasma membrane of the sperm head (Bailey et al. 2000). Canvin and Buhr (1989b) applied fluorescence polarisation and found that cooling and reheating of porcine plasma membranes significantly alters the membrane molecular organization and thereby its functionality (Sklar et al. 1979). The authors further found that the fluidity and therefore molecular organization of plasma membranes from the of boar spermatozoa differ from the sperm head. Their results indicated a differential temperature sensitivity between head and the rest of the sperm body membranes (Canvin and Buhr 1989b). Other authors also found an increased fluidity in cold-shocked (Robertson et al. 1990) and frozen/thawed (Buhr et al. 1989) boar spermatozoa. The membrane changes induced by cold shock were not reversible upon rewarming. Cryo-microscopical examination of ram spermatozoa loaded with a marker for membrane integrity (FDA) revealed that exposure to low temperatures followed by warming differentially affected the plasma membranes over the principal-piece, midpiece, and head, with the head membrane inevitably damaged (Holt and North 1994). Further investigation showed a significant sperm membrane permeabilization after exposure to a high salt concentration followed by restoration of osmotic equilibrium as would be generated during a freeze-thaw cycle. Because of the temperature and osmotic effects, both freezing and thawing induced tremendous alterations in cell water volume, which usually causes considerable mechanical stress on the cell membranes (Hammerstedt et al. 1990, Noiles et al. 1993, Noiles et al. 1995).

At physiological temperatures, freeze-fracture electron micrographs of bull and boar head plasma membranes exhibit a random distribution of membrane proteins (De Leeuw et al. 1991). During cooling, phase transitions changed sperm membrane ultra structure such that particle-free regions in bovine and protein aggregation in porcine sperm replace the random distribution. Because boar spermatozoa are known to be sensitive to cooling, the differences between theses species may indicate variable degrees of damage (Bailey et al. 2000). These ultrastructural modifications were not fully reversible after rewarming.

Cryo-preservation does affect lipid composition and organisation of sperm plasma membranes in boars (Buhr et al. 1989). Maldjian et al. (2005) observed a significant reduction in cholesterol in spermatozoa after cryo-preservation, which was correlated 
with an increased number of acrosome-reacted cells and changes in motility parameters.

Transbilayer-phospholipid asymmetry also was disrupted in ram sperm plasma membranes after cryo-preservation (Hinkovska-Galcheva et al. 1989, Muller et al. 1999). Ultra-structural damage to membranes due to cryo-preservation destabilized them, predisposing spermatozoa to gross morphological defects, such as missing and abnormal acrosomes (Robertson et al. 1990).

Phase transition and other ultrastructural modifications of the plasma membranes during cooling and re-warming may play a role in the poor fertility of cryo-preserved spermatozoa. It is likely that reorganization of sperm membrane lipids disturbs the lipid-lipid and lipid-protein interactions required for normal membrane function (Parks and Graham 1992a).

Plasma membrane disruption due to cooling or freezing favours the loss of cations and enzymes from spermatozoa (Harrison and White 1972), providing some explanation for early observations that cold shock irreversibly depresses sperm motility and metabolic activity (White 1993). Cold shock also destroys the selective permeability of sperm membranes to calcium, thus leading to excessive intracellular levels, which reduce motility and lead to necrosis (Simpson and White 1986, Robertson et al. 1990). Cryo-preservation, in the presence of a cryo-protectant, is considered to be a more moderate treatment than cold shock, since a subpopulation of spermatozoa survives and maintains fertilizing capacity, despite an overall reduction in the percentage of motile and viable cells. In contrast, the computerassessed motility of bovine sperm immediately after thawing, is not correlated with fertility (Bailey and Buhr 1994). Additionally, despite preservation of adequate motility, cryo-preserved human spermatozoa exhibit significant membrane damage as indicated by subnormal hypo-osmotic swelling tests (Check and Check 1991).

Once spermatozoa approach the site of fertilization, they attach transiently to the oviductal epithelial cells, experience capacitation and hyperactivation, bind to the oocyte zona pellucida, undergo acrosome reaction, penetrate the zona, and then finally fuse with and penetrate the oolemma. Impaired sperm membrane function due to cryo-preservation inevitably affects each of these processes and diminishes the likelihood of a successful fertilisation. Poorly motile spermatozoa are less likely to 
arrive at the site of fertilization in vivo or penetrate the oocyte. Moreover, the motile sperm population itself is adversely affected by cryo-preservation.

The structural reorganization of sperm head plasma membranes after freezing and thawing appears to disrupt the ability of spermatozoa to interact normally with cells of the female genital tract. In pigs, spermatozoa stored at $18^{\circ} \mathrm{C}$ penetrated fewer zona-free hamster eggs than did fresh spermatozoa, and penetration by cryopreserved spermatozoa was markedly reduced (Clarke and Johnson 1987). Reduced sperm binding is likely a consequence of membrane injury, possibly by structural damage to the sperm receptors or by incomplete receptor aggregation.

After cryo-preservation, surviving boar, bull and human spermatozoa contained more intracellular calcium than before, reflecting impaired membrane selective permeability mechanisms (Robertson et al. 1990, Bailey and Buhr 1994, Mclaughlin and Ford 1994). The elevated intracellular calcium levels of cryo-preserved spermatozoa and their reduced capacity to maintain normal concentrations of this cation (Bailey and Buhr 1994, Mclaughlin and Ford 1994) may also partly explain the poorer fertility of sperm after thawing. Intracellular calcium levels increase during capacitation (Parrish et al. 1999), hyperactivation (Suarez et al. 1993), and the zona pellucida-induced acrosome reaction (Bailey and Storey 1994, Florman 1994). Such calcium regulatory mechanisms during capacitation (Parrish et al. 1999) and the acrosome reaction (Florman et al. 1998) are complex, involving intracellular stores and voltage-dependent calcium channels. Disruption of capacitation and/or the acrosome reaction would severely compromise the fertilizing potential of spermatozoa, which may account for observations that the in vivo fertility rates of cryo-preserved bovine semen are correlated with the ability of the spermatozoa to moderate internal calcium levels (Bailey and Storey 1994).

Watson (1995) suggested that cryopreservation-induced modifications to sperm membranes make them more reactive to their environment after thawing such that they are in a partially capacitated state. Perez et al. (1996) showed that cryopreserved ram spermatozoa undergo capacitation more quickly than fresh controls as assessed by reactivity to calcium ionophore and the chlortetracycline (CTC) fluorescent assay. CTC fluorescence also revealed a greater proportion of capacitated spermatozoa due to cooling and immediately after thawing in bull (Cormier et al. 1997), ram (Gillan et al. 1997), and boar (Maxwell and Johnson 1997). Watson 
(1995) suggested that cryo-preservation introduces a sublethal modification of the sperm membranes, which renders them more sensitive to the environment after thawing.

\subsubsection{Significance of reactive oxygen species (ROS)}

An increasing number of studies show that reactive oxygen species (ROS) play an important role in fertility. They are involved in physiological sperm function including hyperactivation, capacitation, acrosome reaction, and zona binding (Kodama et al. 1996, De Lamirande et al. 1997). Conversely, when the balance between ROS production and detoxification by antioxidants is disrupted, an excess of ROS creates oxidative stress. ROS such as $\mathrm{H}_{2} \mathrm{O}_{2}$ are known to arrest motility and block oxidative metabolism in spermatozoa (Tosic 1947). In mice, ROS lower sperm penetration rates into the oocyte and block the sperm-egg fusion involving oxidation of sperm -SH groups (Mammoto et al. 1996). Sperm DNA damage caused by ROS also has been reported to have consequences for the post fertilization embryo development (Aitken et al. 1998).

Increased ROS production in both human sperm and seminal leukocytes during cooling to $4^{\circ} \mathrm{C}$ was reported by Wang et al. (1997). Mainly leukocytes produce large amounts of ROS if stimulated (Krausz et al. 1992). In somatic cells, ROS leakage from the mitochondrial respiratory chain has been evaluated at 2 to $5 \%$ (Boveris 1977), and this is probably a major source of ROS produced in sperm mitochondria. Aitken et al. (1997) hypothesized that a NADH/NADPH oxidase could exist on spermatozoa as it exists in many other somatic cell types. Specifically, the activation of an aromatic amino acid oxidase following the death of ram and bull spermatozoa has been identified as a major source of ROS production (Tosic 1947, Upreti et al. 1998). Release of such an oxidase from dead spermatozoa reduced the motility and viability of intact bull spermatozoa (Shannon and Curson 1972).

Unsaturated fatty acids, which predominate the composition of sperm membranes, are susceptible to peroxidation (Halliwell and Gutteridge 1984), and the consequences are numerous, ranging from membrane damage, inhibition of respiration to leakage of intracellular enzymes (White 1993). Especially boar 
spermatozoa are sensitive to peroxidative damage due to the high content of unsaturated fatty acids in the phospholipids of the plasma membrane (Parks and Graham 1992a, Cerolini et al. 2000) and the relative low antioxidant capacity of boar seminal plasma (Brezezinska-Slebodzinska et al. 1995).

It has been demonstrated in human (Alvarez and Storey 1992), bull (O'flaherty et al. 1997) and mouse spermatozoa (Mazur et al. 2000) that cryopreservation is associated with oxidative stress. Moreover, freezing and thawing of bovine spermatozoa increased the generation of ROS (Chatterjee and Gagnon 2001b), causing DNA damage (Lopes et al. 1998), cytoskeleton alterations (Hinshaw et al. 1986), inhibition of the sperm-oocyte fusion (Aitken et al. 1989) and affecting the sperm axoneme, leading to loss of motility (De Lamirande and Gagnon 1992a).

Centrifugation which is part of the porcine semen freezing protocol, presents stress to spermatozoa and may cause an increase in lipid peroxidation (Shekarriz et al. 1995). This may be more obvious as spermatozoa are stored in liquid nitrogen that increases peroxidation of membrane lipids itself (Chatterjee and Gagnon 2001b).

Observations that addition of antioxidants to semen improves sperm quality provide indirect evidence for the damaging effects of ROS on sperm function. Studies to preserve unfrozen semen revealed that extenders supplemented with exogenous antioxidants such as Catalase, greatly aided to maintain sperm quality (Foote 1967). Inclusion of antioxidants such as alpha-tocopherol, catalase and ascorbate had a protective effect on metabolic activity and cellular viability of cryopreserved bovine (Beconi et al. 1991, Beconi et al. 1993, Bilodeau et al. 2002, Klinc 2005) and porcine spermatozoa (Pena et al. 2003c, Pena et al. 2004b, Roca et al. 2005b).

Table 3 gives an overview to antioxidants that were used to improve the quality of frozen/thawed semen. 
Table 3: Antioxidants that have been used to improve the quality of frozen/thawed spermatozoa in different species

\begin{tabular}{|c|c|c|c|}
\hline Antioxidant & Material and Methods & Result & Reference \\
\hline \multirow[t]{4}{*}{ ascorbic acid } & Ascorbic acid was added to the freezing media of human sperm & $\begin{array}{l}\text { Ascorbic acid did not show any effects on sperm } \\
\text { motility and hyperosmotic swelling test }\end{array}$ & Askari et al. 1994b \\
\hline & $\begin{array}{l}\text { Ascorbic acid was added to the tris-based freezing-diluent for } \\
\text { ram semen }\end{array}$ & $\begin{array}{l}\text { Ascorbic acid had no positive effect and reduced } \\
\text { motility in concentrations above } 50 \mathrm{mMol}\end{array}$ & $\begin{array}{l}\text { Sanchez-Partida et } \\
\text { al. } 1997\end{array}$ \\
\hline & $\begin{array}{l}\text { Ascorbic acid was added to whole milk, glycerol extender of } \\
\text { bull semen }\end{array}$ & $\begin{array}{l}\text { Addition of antioxidants did not show any beneficial } \\
\text { effects on sperm motility }\end{array}$ & Foote et al. 2002 \\
\hline & $\begin{array}{l}\text { Ascorbic acid was added to the freezing media of equine } \\
\text { spermatozoa }\end{array}$ & $\begin{array}{l}\text { Ascorbic acid did not improve sperm motility, DNA } \\
\text { fragmentation, acrosomal integrity, viability or MMP } \\
\text { after thawing }\end{array}$ & $\begin{array}{l}\text { Baumber et al. } \\
2005\end{array}$ \\
\hline \multirow[t]{2}{*}{$\begin{array}{l}\text { BHT butylated } \\
\text { hydroxytoluene }\end{array}$} & $\begin{array}{l}\text { BHT was added to Beltsville thawing solution in a concentration } \\
\text { of } 0.05 \text { to } 2 \mathrm{mMol} \text { BHT; Boar spermatozoa were subsequently } \\
\text { cooled to } 5^{\circ} \mathrm{C}\end{array}$ & $\begin{array}{l}\text { Boar spermatozoa acquired resistance to cold shock } \\
\text { immediately after exposure to } 0.2-2.0 \mathrm{mMol} \text { BHT as } \\
\text { judged by motility (the proportion of motile } \\
\text { spermatozoa) and acrosomal integrity. }\end{array}$ & $\begin{array}{l}\text { Bamba and Cran } \\
1992\end{array}$ \\
\hline & BHT was added to the freezing media for boar spermatozoa & $\begin{array}{l}\text { Post thaw sperm survival was higher when sperm } \\
\text { where frozen with } 0.2,0.4 \text { and } 0.8 \mathrm{mMol} \text { BHT, lipid } \\
\text { oxidation was further reduced, embryo development } \\
\text { after IVF could be improved with BHT }\end{array}$ & Roca et al. 2004 \\
\hline Catalase & Catalase was added to the freezing media of boar spermatozoa & $\begin{array}{l}\text { Catalase alone or in combination with SOD } \\
\text { improved post-thaw survival of boar sperm; }\end{array}$ & Roca et al. $2005 b$ \\
\hline
\end{tabular}




\begin{tabular}{|c|c|c|c|}
\hline Antioxidant & Material and Methods & Result & Reference \\
\hline & Catalase was added to the freezing media of equine spermatozoa & $\begin{array}{l}\text { Catalase did not improve sperm motility, DNA } \\
\text { fragmentation, acrosomal integrity, viability or MMP } \\
\text { after thawing }\end{array}$ & $\begin{array}{l}\text { Baumber et al. } \\
2005\end{array}$ \\
\hline & $\begin{array}{l}\text { Catalase was added to cooling and freezing extender of bull } \\
\text { spermatozoa after flowcytometrical sex sorting }\end{array}$ & $\begin{array}{l}\text { Addition of antioxidants significantly improved post- } \\
\text { thawing motility, acrosome integrity and were able } \\
\text { to restore fertility of sex-sorted semen vs. control } \\
\text { spermatozoa }\end{array}$ & Klinc 2005 \\
\hline Carnosine & $\begin{array}{l}\text { Carnosine was added to TRIS-based freezing-diluent for ram } \\
\text { semen }\end{array}$ & $\begin{array}{l}\text { Carnosine had no positive effect and reduced } \\
\text { motility in concentrations above } 50 \mathrm{mMol}\end{array}$ & $\begin{array}{l}\text { Sanchez-Partida et } \\
\text { al. } 1997\end{array}$ \\
\hline \multirow[t]{3}{*}{ reduced glutathione (GSH) } & GSH was added to whole milk, glycerol extender of bull semen & $\begin{array}{l}\text { Sperm motility was improved by } 6-11 \% \text { after } \\
\text { freezing with } 0.5 \mathrm{mMol} \text { of GSH with and without } \\
\text { SOD }\end{array}$ & Foote et al. 2002 \\
\hline & GSH was added to the freezing media of equine spermatozoa & $\begin{array}{l}\text { GSH did not improve sperm motility, DNA } \\
\text { fragmentation, acrosomal integrity, viability or MMP } \\
\text { after thawing }\end{array}$ & $\begin{array}{l}\text { Baumber et al. } \\
2005\end{array}$ \\
\hline & $\begin{array}{l}\text { GSH was added to the thawing extender of frozen-thawed boar } \\
\text { sperm }\end{array}$ & $\begin{array}{l}\text { GSH in the thawing extender decreased number of } \\
\text { capacitated sperm, chromatin condensation and } \\
\text { percentage of sperm with changes in sulfhodyl } \\
\text { groups, IVF rates where improved }\end{array}$ & Gadea et al. 2005 \\
\hline Rebamipide & $\begin{array}{l}\text { Rebamipide was added to the freezing medium for human } \\
\text { spermatozoa }\end{array}$ & $\begin{array}{l}\text { Addition of } 100 \text { and } 300 \mu \mathrm{mol} \text { improved sperm } \\
\text { motility after thawing }\end{array}$ & Park et al. 2003 \\
\hline
\end{tabular}




\begin{tabular}{|c|c|c|c|}
\hline Antioxidant & Material and Methods & Result & Reference \\
\hline \multirow[t]{4}{*}{$\begin{array}{l}\text { Superoxide dismutase } \\
\text { (SOD) }\end{array}$} & Bull sperm were frozen in the presence of SOD & $\begin{array}{l}\text { SOD decreased the number of capacitated sperm } \\
\text { after thawing }\end{array}$ & $\begin{array}{l}\text { O'flaherty et al. } \\
1997\end{array}$ \\
\hline & SOD was added to whole milk, glycerol extender of bull semen & $\begin{array}{l}\text { Addition of SOD did not show any beneficial effect } \\
\text { on sperm motility }\end{array}$ & Foote et al. 2002 \\
\hline & SOD was added to the freezing media of boar spermatozoa & $\begin{array}{l}\text { SOD alone or in combination with Catalase } \\
\text { improved post-thaw survival of boar sperm }\end{array}$ & Roca et al. $2005 b$ \\
\hline & SOD was added to the freezing media of equine spermatozoa & $\begin{array}{l}\text { SOD did not improve sperm motility, DNA } \\
\text { fragmentation, acrosomal integrity, viability or MMP } \\
\text { after thawing but SOD increase DNA fragmentation }\end{array}$ & $\begin{array}{l}\text { Baumber et al. } \\
2005\end{array}$ \\
\hline $\begin{array}{l}\text { 4-hydroxy-2, 2, 6, 6- } \\
\text { tetramethylpeperidine } \\
\text { (Tempol) }\end{array}$ & $\begin{array}{l}\text { Tempol was added to whole milk, glycerol extender of bull } \\
\text { semen }\end{array}$ & $\begin{array}{l}\text { Addition of Tempol did not show any beneficial } \\
\text { effect on sperm motility }\end{array}$ & Foote et al. 2002 \\
\hline $\begin{array}{l}2,2,6,6- \\
\text { tetramethylpeperidine-1- } \\
\text { oxyl (Tempo) }\end{array}$ & $\begin{array}{l}\text { Tempo was added to whole milk, glycerol extender of bull } \\
\text { semen }\end{array}$ & $\begin{array}{l}\text { Addition of Tempol did not show any beneficial } \\
\text { effect on sperm motility }\end{array}$ & Foote et al. 2002 \\
\hline \multirow[t]{2}{*}{ Vitamin E, TROLOX } & $\begin{array}{l}\text { Vitamin E was added to freeze/thawing media of human } \\
\text { spermatozoa and motility changes after thawing were evaluated }\end{array}$ & $\begin{array}{l}\text { Vitamin } \mathrm{E} \text { had no effect on motility after freezing } \\
\text { and thawing but showed a partial inhibitory effect on } \\
\text { lipid peroxidation }\end{array}$ & $\begin{array}{l}\text { Alvarez and Storey } \\
1993\end{array}$ \\
\hline & $\begin{array}{l}\text { Alpha-tocopherol was added to the freezing media of human } \\
\text { sperm }\end{array}$ & $\begin{array}{l}\text { Alpha-tocopherol showed little but significant } \\
\text { positive effect on sperm motility }\end{array}$ & Askari et al. 1994b \\
\hline
\end{tabular}




\begin{tabular}{|c|c|c|c|}
\hline Antioxidant & Material and Methods & Result & Reference \\
\hline & Ram spermatozoa were frozen in the presence of vitamin E & $\begin{array}{l}\text { Vitamin E improved cell membrane integrity and } \\
\text { centrifugal counter-current distribution }\end{array}$ & Ollero et al. 1996 \\
\hline & $\begin{array}{l}\text { Bull sperm were frozen in the presence of vitamin } \mathrm{E} \text { alone or in } \\
\text { combination with vitamin C }\end{array}$ & $\begin{array}{l}\text { In both cases the number of capacitated spermatozoa } \\
\text { were reduced after thawing, vitamin E further } \\
\text { protected the plasma membrane integrity }\end{array}$ & $\begin{array}{l}\text { O'flaherty et al. } \\
1997\end{array}$ \\
\hline & Alpha-tocopherol was added to the freezing media of bull sperm & $\begin{array}{l}\text { IVF results were reduced when semen was frozen } \\
\text { with vitamin E }\end{array}$ & Dalvit et al. 1998 \\
\hline & $\begin{array}{l}\text { Trolox was added to the egg-yolk based freezing medium for } \\
\text { boar spermatozoa }\end{array}$ & $\begin{array}{l}200 \mu \mathrm{mol} \text { improved the post-thawing motility and } \\
\text { mitochondrial activity significantly in both the } \\
\text { sperm-rich and sperm-poor fraction of the boar } \\
\text { ejaculate }\end{array}$ & $\begin{array}{l}\text { Pena et al. 2003b, } \\
2004 b\end{array}$ \\
\hline & $\begin{array}{l}\text { Alpha-tocopherol was added to the freezing media of equine } \\
\text { spermatozoa }\end{array}$ & $\begin{array}{l}\text { Alpha-tocopherol did not improve sperm motility, } \\
\text { DNA fragmentation, acrosomal integrity, viability or } \\
\text { MMP after thawing }\end{array}$ & $\begin{array}{l}\text { Baumber et al. } \\
2005\end{array}$ \\
\hline & $\begin{array}{l}\text { Alpha-tocopherol was added to the freezing media of boar } \\
\text { sperm }\end{array}$ & $\begin{array}{l}200 \mu \mathrm{g} / \mathrm{ml} \text { to } 1000 \mu \mathrm{g} / \mathrm{ml} \text { alpha-tocopherol improved } \\
\text { sperm motility post thawing, } 200 \mu \mathrm{g} / \mathrm{ml} \text { alpha- } \\
\text { tocopherol protected spermatozoa against lipid } \\
\text { peroxidation }\end{array}$ & $\begin{array}{l}\text { Breininger et al. } \\
2005\end{array}$ \\
\hline
\end{tabular}


Given their importance in fertility, a significant role of ROS in sperm cryoinjury is likely. In vitro capacitation and tyrosine phosphorylation of sperm proteins are correlated with superoxide anion generation in human spermatozoa (De Lamirande and Gagnon 1998). Conversely, both superoxide dismutase and catalase inhibited capacitation and tyrosine phosphorilation (Leclerc et al. 1997). Bailey et al. (2000) speculated that cryoinjury may be induced by ROS activity generated during sperm processing.

\subsubsection{Nucleus; DNA-integrity}

Fraser and Strzezek (2005) have shown that cryo-preservation of boar semen enhances oxidative stress, which has a detrimental effect on the sperm DNA integrity. In their study, applying the neutral comet assay, they found that DNA damage increased in cryo-preserved boar spermatozoa, regardless of the extender type and packaging material. Similar findings were reported for cryo-preserved human and stallion spermatozoa using the comet assay (Duty et al. 2002, Linfor and Meyers 2002). Fraser and Strzezek (2005) used the DNA-binding stain SYBR-14 and H33258 as well a single-cell electrophoresis assay. They proposed that also activation of endonucleases, released from deteriorated plasma membranes of frozenthawed spermatozoa increase in post-thaw DNA damage. Mammalian spermatozoa contain a mechanism by which they can digest their own DNA when exposed to a stressful environment (Ward and Ward 2004). According to Sotolongo (2005), endonucleases present in sperm plasma membrane are activated by freezing and thawing. Extensive DNA damage, with loss of sperm motility and ability to fuse with the oocyte, has been observed during high oxidative stress in human and bovine spermatozoa (Aitken et al. 1998, Baumber et al. 2003). Although the involvement of ROS in cryo-induced DNA damage has not been fully elucidated, it has been assumed that under such conditions DNA is under constant attack from ROS inducing DNA breaks (Halliwell and Aruoma 1991).

As mammalian spermatozoa have been shown to lack a DNA repair system, it is envisaged to have a multi-level defence, which however do not completely protected from oxidative stress. 
Addition of antioxidants to freezing and thawing extenders have been used to improve fertility (Pena et al. 2003b, Roca et al. 2005b).

\subsubsection{Tests to evaluate sperm functionality}

Table 4 provides an overview of in vitro tests to monitor deterioration of sperm membranes, organelles, DNA, and functionality. These tests can help to predict the fertility of a given sperm sample. In order predict the fertility accurately a combination of several tests is required (Gadea 2005, Woelders 1991, Waberski et al. 1999). 
Table 4: $\quad$ Tests to monitor changes in sperm membranes, organelles, DNA, and functionality applicable to boar semen

\begin{tabular}{|c|c|c|c|}
\hline Probe or Test & Principle & Comments & References \\
\hline \multicolumn{4}{|l|}{ Membrane and organelle integrity } \\
\hline \multicolumn{4}{|l|}{ Plasma membrane } \\
\hline $\begin{array}{l}\text { Hoechst 33258, YoPro-1, } \\
\text { propidium iodide, } \\
\text { ethidium homodimer, } \\
\text { ToPro-3, TOTO, } \\
\text { Bromphenolblue }\end{array}$ & $\begin{array}{l}\text { Membrane-impermeable fluorescent probe with affinity for DNA } \\
\text { penetrate only penetrates membrane damaged spermatozoa (live } \\
\text { stain) }\end{array}$ & & $\begin{array}{l}\text { Hong et al. 1988, Mclaughlin et } \\
\text { al. 1992, Harrison et al. 1996, } \\
\text { Pintado et al. 2000, Garner et al. } \\
\text { 1986, Cheng et al. 1996, } \\
\text { Haugland 2004; Schrader et al. } \\
\text { 1986, Geisler } 1990\end{array}$ \\
\hline $\begin{array}{l}\text { Fluorescein diacetat, } \\
\text { carboxy (methyl) derivates } \\
\text { (i.e. FDA, CFDA) } \\
\text { SYTO-17, SYBR-14 } \\
\text { carboxyseminaphthorhodal } \\
\text { fluor-1 (SNARF-1) }\end{array}$ & $\begin{array}{l}\text { Amphipatic probe pass intact sperm membranes and enter living } \\
\text { sperm, entered probes are deacylated by intracellular esterases } \\
\text { immediately leaving the probe membrane-impermeable, but } \\
\text { probes can leave membrane damaged stains (dead stain) } \\
\text { deacylation results in DNA-binding of this probe with } \\
\text { fluorescent properties } \\
\text { SNARF-1 is an intracellular pH-Indicator that diffuses into living } \\
\text { cells; esterases present in live cells hydrolyze the acetoxymethyl } \\
\text { ester leaving SNARF-1 trapped within the cell cytoplasm }\end{array}$ & $\begin{array}{l}\text { Live and dead stains are often used in } \\
\text { combination as counter stains are } \\
\text { available as LIVE/DEAD Sperm } \\
\text { Viability Kits }\end{array}$ & $\begin{array}{l}\text { Donoghue et al. 1995, Garner et } \\
\text { al. 1994, Garner and Johnson } \\
1995 \\
\text { Thomas et al. 1997, Krienke } \\
2003 \\
\text { Pena et al. } 2005\end{array}$ \\
\hline $\begin{array}{l}\text { Hypo-osmotic swelling } \\
\text { test (HOST) }\end{array}$ & $\begin{array}{l}\text { Only membrane intact spermatozoa swell in hypo-osmotic } \\
\text { conditions; the effect is more easily visible in the tail than the } \\
\text { sperm head }\end{array}$ & & $\begin{array}{l}\text { Jeyendran et al. 1984, Jeyendran } \\
\text { et al. 1992, Vazquez et al. 1997, } \\
\text { Petrunkina et al. } 2000\end{array}$ \\
\hline
\end{tabular}




\begin{tabular}{|c|c|c|c|}
\hline Probe or Test & Principle & Comments & References \\
\hline \multicolumn{4}{|l|}{ Acrosome } \\
\hline $\begin{array}{l}\text { Lectin conjugates of } \\
\text { Pisum sativum (PSA), } \\
\text { Arachis hypogaea (PNA), } \\
\text { Triticum vulgaris (WGA), } \\
\text { Concanavalia ensiformis } \\
\text { (ConA), Ulex europaeus } \\
\text { (UEA) }\end{array}$ & $\begin{array}{l}\text { Lectins are conjugated with fluorescent groups and bind to } \\
\text { specific carbohydrate moieties of glycoproteins exclusively } \\
\text { localized in the acrosome; detection can be done in flow } \\
\text { cytometry and life cell imaging microscopy with living and fixed } \\
\text { and permeabilized spermatozoa; in living sperm the absence of } \\
\text { fluorescence is indicative for an intact acrosome, in fixed and } \\
\text { permeabilized sperm, full fluorescent sperm are considered intact }\end{array}$ & $\begin{array}{l}\text { An array of fluorescent groups can be } \\
\text { used in combination with the lectins, } \\
\text { most common are FITC, TRITC and } \\
\text { RPE, PNA labelling is specific for the } \\
\text { outer acrosomal membrane, PSA } \\
\text { labels acrosomal matrix glycoprotein }\end{array}$ & $\begin{array}{l}\text { Holden et al. 1990, Szasz et al. } \\
\text { 2000, Cheng et al. 1998, Flesch } \\
\text { et al. 1998, Töpfer-Petersen et } \\
\text { al. 1984, Malmi et al. 1987, } \\
\text { Gadella and Harrison 2000, } \\
\text { 2002, Gillan et al. 2005, } \\
\text { Jimenez et al. 2002, Sinowatz et } \\
\text { al. } 1989\end{array}$ \\
\hline LysotrackerTM dyes & $\begin{array}{l}\text { Fluorescent dyes can be used to specifically stain the intact } \\
\text { acidified acrosome }\end{array}$ & $\begin{array}{l}\text { A variety of Lysotracker dyes with } \\
\text { different absorption and emission } \\
\text { spectra are available }\end{array}$ & Thomas et al. 1997, 1998 \\
\hline $\begin{array}{l}\text { lectin Trypsin inhibitor } \\
\text { from Soybean (SBTI) }\end{array}$ & $\begin{array}{l}\text { SBTI is specific for proacrosin and if conjugated to a } \\
\text { fluorochrome, allows the recognition of acrosome damaged } \\
\text { spermatozoa }\end{array}$ & & Bussalleu et al. 2005 \\
\hline $\begin{array}{l}\text { Monoclonal antibodies } \\
\text { (i.e. Mab ACR.2, mAk } \\
\text { 18,6) }\end{array}$ & $\begin{array}{l}\text { Monoclonal antibodies specific for either intra- or extra- } \\
\text { acrosomal proteins are fluorescence-labelled can discriminate } \\
\text { acrosome reacted spermatozoa }\end{array}$ & & $\begin{array}{l}\text { Peknicova and Moos 1990, } \\
\text { Töpfer-Petersen et al. 1986, } \\
\text { Bathla and Sidhu 1998, Töpfer- } \\
\text { Petersen et al. 1988, Töpfer- } \\
\text { Petersen et al. 1985, Zhang et al. } \\
\text { 1990, Ivanova and Mollova } \\
1993\end{array}$ \\
\hline
\end{tabular}




\begin{tabular}{|c|c|c|c|}
\hline Probe or Test & Principle & Comments & References \\
\hline Morphological assessment & $\begin{array}{l}\text { Determination of the percentage of spermatozoa with } \\
\text { morphological abnormalities especially concerning the acrosome }\end{array}$ & $\begin{array}{l}\text { A variety of dyes are available for } \\
\text { acrosome staining and recognition of } \\
\text { damages (i.e. Eosin, Farelly) }\end{array}$ & $\begin{array}{l}\text { Krause 1966, Wells and Awa } \\
\text { 1970, Würgau 1986, } \\
\text { Lichtenstern } 1995\end{array}$ \\
\hline \multicolumn{4}{|l|}{ Mitochondria } \\
\hline $\begin{array}{l}\text { Rhodamine } 123 \text {, } \\
\text { Mitotracker }\end{array}$ & $\begin{array}{l}\text { Only fluoresces in intact mitochondria when a proton gradient } \\
\text { over the inner mitochondrial membrane is build up as a sign of } \\
\text { an active aerobic ATP production, in unstained sperm the aerobic } \\
\text { ATP production has stopped }\end{array}$ & $\begin{array}{l}\text { Rhodamine } 123 \text { fluoresces red, } \\
\text { Mitotracker TM are available with } \\
\text { different absorption and emission } \\
\text { spectra }\end{array}$ & Garner et al. 1997 \\
\hline $\begin{array}{l}\text { Mitotracker Orange CM- } \\
\text { H2TMROS and } \\
\text { Mitotracker X-Rosamine } \\
\text { CM-H2XROS }\end{array}$ & $\begin{array}{l}\text { Dyes become fluorescent in sperms with functional mitochondria } \\
\text { undertaking oxidative respiration }\end{array}$ & & $\begin{array}{l}\text { Gadella and Harrison 2002, De } \\
\text { Vries et al. } 2003\end{array}$ \\
\hline JC-1 & $\begin{array}{l}\text { Dye changes fluorescence properties due to changes in the } \\
\text { potential of the inner mitochondrial membrane; JC-1 switches } \\
\text { orange fluorescence in the aerobic functional mid-piece towards } \\
\text { green in depolarized inner mitochondrial membranes }\end{array}$ & & Garner and Thomas 1999 \\
\hline $\begin{array}{l}\text { Computer assisted sperm } \\
\text { analysis (CASA) }\end{array}$ & $\begin{array}{l}\text { Sperm motility characteristics (i.e. progressive motility, path } \\
\text { velocity, curvilinear velocity) increase, when mitochondrial } \\
\text { membrane potential increases }\end{array}$ & $\begin{array}{l}\text { Alternative and indirect prove of } \\
\text { mitochondrial function }\end{array}$ & $\begin{array}{l}\text { Kasai et al. 2002, Pena et al. } \\
\text { 2003b }\end{array}$ \\
\hline
\end{tabular}




\begin{tabular}{|c|c|c|c|}
\hline Probe or Test & Principle & Comments & References \\
\hline \multicolumn{4}{|l|}{ Lipid organisation } \\
\hline Chlortetracycline (CTC) & $\begin{array}{l}\text { Fluorescent probe binds to sperm plasma membrane in a } \\
\mathrm{Ca} 2+/ \mathrm{Mg} 2+\text { dependent manner; CTC stains viable sperm cells } \\
\text { with the surface membrane containing } \mathrm{Ca} 2+\text { above a certain } \\
\text { threshold, the staining is scored in different pattern that allows } \\
\text { conclusions about capacitation and acrosomal status }\end{array}$ & $\begin{array}{l}\text { Probe cannot distinguish between } \\
\text { calcium dependent and independent } \\
\text { ways of capacitation, frozen-thawed } \\
\text { sperm appear capacitated }\end{array}$ & $\begin{array}{l}\text { Chandler and Williams 1978b, } \\
\text { 1978a, Ward and Storey 1984, } \\
\text { Saling and Storey 1979, Kaneto } \\
\text { et al. 2002, Green and Watson } \\
\text { 2001, Gadella and Harrison } \\
2002\end{array}$ \\
\hline $\begin{array}{l}\text { Fluo-3-acetomethoxy(AM) } \\
\text { ester, fura red-AM, quin-2 } \\
\text { AM, indo-1 AM }\end{array}$ & $\begin{array}{l}\text { Fluorescent probe can penetrate aqueous membrane } \\
\text { compartments and change spectra when bound to calcium; probe } \\
\text { delivers information about intracellular free calcium believed to } \\
\text { be associated with capacitation }\end{array}$ & & Green and Watson 2001 \\
\hline Merocyanine 540 (M540) & $\begin{array}{l}\text { Decreased packaging order of phospholipids in outer leaflet of } \\
\text { the plasma membrane lipid bilayer, occurring during } \\
\text { capacitation, allows probe to migrate into the hydrophobic core } \\
\text { of the membrane and stain sperm cell; }\end{array}$ & $\begin{array}{l}\text { M540 detects changes in sperm } \\
\text { membrane organisations that happen } \\
\text { earlier than detectable via CTC, M540 } \\
\text { is also } \mathrm{Ca} 2+\text { independent }\end{array}$ & $\begin{array}{l}\text { Williamson et al. 1983, Langner } \\
\text { and Hui 1993, Ashworth et al. } \\
1995\end{array}$ \\
\hline C6NBD-phospholipids & $\begin{array}{l}\text { Incorporating, labelled phospholipid analogue is used to assess } \\
\text { degree of phospholipids asymmetry in the plasma membrane of } \\
\text { the sperm cell }\end{array}$ & & Gadella et al. 1999b \\
\hline
\end{tabular}




\begin{tabular}{|c|c|c|c|}
\hline Probe or Test & Principle & Comments & References \\
\hline Annexin-V & $\begin{array}{l}\text { Fluorochrome conjugated, calcium-dependent phosphatidylserine } \\
\text { (PS)-binding protein; allows recognition of cells with exposed } \\
\text { PS as in capacitated sperm }\end{array}$ & & Gadella et al. 1999b \\
\hline Ro-09-0198 & $\begin{array}{l}\text { Fluorochrome conjugated, calcium-dependent } \\
\text { phosphatidylethanolamine (PE)-binding protein; allows } \\
\text { recognition of cells with exposed PE as in capacitated sperm }\end{array}$ & & De Vries et al. 2003 \\
\hline \multicolumn{4}{|l|}{ Lipid peroxidation } \\
\hline $\mathrm{C}_{11} \mathrm{BODIPY}^{581 / 591}$ & $\begin{array}{l}\text { Fluorescent analogue reporter probe for unsaturated fatty acids, } \\
\text { probe changes its fluorescent properties when peroxidized by } \\
\text { ROS or RNS }\end{array}$ & $\begin{array}{l}\text { Location of peroxidation can be } \\
\text { measured applying confocal laser } \\
\text { scanning microscopy }\end{array}$ & $\begin{array}{l}\text { Brouwers et al. 2005, Drummen } \\
\text { et al. } 2004\end{array}$ \\
\hline $\begin{array}{l}\text { Thiobarbituric acid } \\
\text { reactive substance } \\
\text { (TBARS) }\end{array}$ & $\begin{array}{l}\text { The concentration of malondialdehyde (MDA) is measured by a } \\
\text { spectrophotometer; MDA is produced due to peroxidative } \\
\text { breakdown of membrane phospholipids }\end{array}$ & & Comaschi et al. 1989 \\
\hline \multicolumn{4}{|l|}{ DNA damage } \\
\hline \multicolumn{4}{|l|}{ DNA condensation } \\
\hline $\begin{array}{l}\text { Transmission electron } \\
\text { microscopy (TEM) }\end{array}$ & $\begin{array}{l}\text { Allows assessment of condensation status of single sperm cells; } \\
\text { condensed nuclei appear homogeneously black in contrast to } \\
\text { non-condensed nuclei }\end{array}$ & $\begin{array}{l}\text { Can only be used in late spermatids } \\
\text { prior to spermiation }\end{array}$ & $\begin{array}{l}\text { Dooher and Bennett 1973, } \\
\text { Roosen-Runge } 1962\end{array}$ \\
\hline $\begin{array}{l}\text { Single cell DNA gel } \\
\text { electrophoresis assay } \\
(\mathrm{COMET})\end{array}$ & $\begin{array}{l}\text { Normally condensed sperm nuclei (minimal migration) and } \\
\text { loosely packed DNA (tailing of DNA) can be distinguished after } \\
\text { fluorescent labelling of sperm DNA; tailing of DNA was noticed } \\
\text { for mice with low expression of protamine } 2\end{array}$ & & Cho et al. 2003 \\
\hline
\end{tabular}




\begin{tabular}{|c|c|c|c|}
\hline Probe or Test & Principle & Comments & References \\
\hline \multicolumn{4}{|l|}{ DNA breaks and nicks } \\
\hline $\begin{array}{l}\text { Sperm chromatine } \\
\text { structure assay (SCSA) }\end{array}$ & $\begin{array}{l}\text { Fluorochrome dye acridine orange stains single and double } \\
\text { stranded DNA differently }\end{array}$ & & $\begin{array}{l}\text { Boe-Hansen et al. } 2005 \text {, } \\
\text { Evenson and Jost } 2000\end{array}$ \\
\hline TUNNEL-assay & $\begin{array}{l}\text { Single stranded DNA in sperm cells is labelled with fluorescent } \\
\text { nucleotide analogues by terminal nucleotide transferase; stained } \\
\text { sperm contain therefore single-stranded DNA }\end{array}$ & & $\begin{array}{l}\text { Sakkas et al. 2003, Parrilla et al. } \\
2003\end{array}$ \\
\hline $\begin{array}{l}\text { 8-Hydroxydeoxyguanosine } \\
\text { (8-OHdG) }\end{array}$ & $\begin{array}{l}\text { 8-OHdG is considered to be a precise and sensitive biomarker of } \\
\text { oxidative DNA damage, level of 8-OHdG in sperm DNA is } \\
\text { determined by high-performance liquid chromatography }\end{array}$ & & Shen et al. 1999 \\
\hline Chromomycin $\mathrm{A}_{3}\left(\mathrm{CMA}_{3}\right)$ & $\begin{array}{l}\text { Fluorochrome detects protamine deficiency in loosely packed } \\
\text { chromatin, which is correlated to the extend of nicked DNA; } \\
\text { used to follow the last compaction steps of DNA to protamines, } \\
\text { fluorescence dye binds to de-protaminated DNA but fails to do } \\
\text { this after protamination of DNA }\end{array}$ & & $\begin{array}{l}\text { Manicardi et al. 1995, Catt et al. } \\
\text { 1997, Sakkas et al. } 1995\end{array}$ \\
\hline \multicolumn{4}{|l|}{ Sperm function and fertility } \\
\hline $\begin{array}{l}\text { Computer assisted sperm } \\
\text { analysis (CASA) }\end{array}$ & $\begin{array}{l}\text { Sperm motility and motility characteristics (i.e. progressive } \\
\text { motility, path velocity, curvilinear velocity) allow conclusions on } \\
\text { sperm fertilization capacity }\end{array}$ & $\begin{array}{l}\text { Sperm motility is not necessarily } \\
\text { correlated with fertility; immotile } \\
\text { sperm might be fully functional and } \\
\text { regain their motility in the female } \\
\text { genital, whereas motile sperm might } \\
\text { have a damaged acrosome and cannot } \\
\text { fertilize an oocyte }\end{array}$ & $\begin{array}{l}\text { Holt et al. 1997, Popwell and } \\
\text { Flowers 2004, Amann and Katz } \\
2004\end{array}$ \\
\hline
\end{tabular}




\begin{tabular}{|c|c|c|c|}
\hline Probe or Test & Principle & Comments & References \\
\hline Oviductal explant assay & $\begin{array}{l}\text { (Electron-)Microscopically evaluation of sperm binding to } \\
\text { oviductal epithelium cells in vitro reveals information about the } \\
\text { capability of spermatozoa to form a functional sperm reservoir in } \\
\text { the oviduct }\end{array}$ & $\begin{array}{l}\text { Cultured explants, vesicles, apical } \\
\text { membranes or monolayer of oviductal } \\
\text { epithelium may be used }\end{array}$ & $\begin{array}{l}\text { Waberski et al. 2006, } \\
\text { Petrunkina et al. 2001, } \\
\text { Raychoudhury and Suarez 1991, } \\
\text { Fazeli et al. 1999, Green et al. } \\
\text { 2001, Dobrinski et al. 1997, } \\
\text { Boilard et al. } 2002\end{array}$ \\
\hline $\begin{array}{l}\text { Sperm penetration assay } \\
\text { (SPA) }\end{array}$ & $\begin{array}{l}\text { The percentage of spermatozoa that enter zona-free hamster } \\
\text { oocytes shows if spermatozoa are capable to successfully interact } \\
\text { and penetrate an oocyte }\end{array}$ & $\begin{array}{l}\text { Neither morphology nor the ability of } \\
\text { the sperm to undergo an acrosome } \\
\text { reaction during in vitro incubation was } \\
\text { correlated with fertility in this study }\end{array}$ & Berger and Parker 1989 \\
\hline $\begin{array}{l}\text { Sperm-zona binding and } \\
\text { penetration of pig oocytes }\end{array}$ & $\begin{array}{l}\text { The capability of boar spermatozoa to bind to fresh or } \\
\text { cryopreserved intact pig oocytes is evaluated to assess sperm } \\
\text { functionality }\end{array}$ & $\begin{array}{l}\text { The capability of sperm for zona- } \\
\text { binding and zona-penetration may } \\
\text { distinguished by passaging oocytes } \\
\text { repeatedly through a narrow-bore } \\
\text { pipette tip to strip off sperm bound to } \\
\text { the zona surface }\end{array}$ & $\begin{array}{l}\text { Ivanova and Mollova 1993, } \\
\text { Lynham and Harrison } 1998\end{array}$ \\
\hline $\begin{array}{l}\text { Hemizona binding assay } \\
\text { (HZA) }\end{array}$ & $\begin{array}{l}\text { The capability of boar spermatozoa to bind to the bisected } \\
\text { hemizona of pig oocytes is evaluated to assess sperm binding } \\
\text { capacity }\end{array}$ & & $\begin{array}{l}\text { Burkman et al. 1988, Fazeli et } \\
\text { al. } 1995\end{array}$ \\
\hline
\end{tabular}




\begin{tabular}{|c|c|c|c|}
\hline Probe or Test & Principle & Comments & References \\
\hline \multirow[t]{2}{*}{$\begin{array}{l}\text { Homologous in vitro } \\
\text { fertilization }\end{array}$} & $\begin{array}{l}\text { The capability of spermatozoa to produce embryos after in-vitro } \\
\text { fertilization of in-vitro or in-vivo matured oocytes is measured to } \\
\text { assess sperm functionality; the formation of pronuclei gives } \\
\text { further information of sperm functionality }\end{array}$ & $\begin{array}{l}\text { Homologous IVF-test have shown } \\
\text { high variation between boars and } \\
\text { ejaculates and are therefore criticized } \\
\text { to not correctly predict fertility } \\
\text { (Waberski et al. 2005) }\end{array}$ & $\begin{array}{l}\text { Xu et al. 1996, Xu 1998, Long } \\
\text { et al. } 1999 \text {, Selles 2003, Miller } \\
\text { et al. } 1998\end{array}$ \\
\hline & $\begin{array}{l}\text { The capability of spermatozoa to penetrate zona-intact but } \\
\text { immature oocytes at germinal vesicle stage (hIVP) is measured } \\
\text { to assess sperm functionality }\end{array}$ & & $\begin{array}{l}\text { Martinez et al. 1993, Vazquez et } \\
\text { al. } 1998\end{array}$ \\
\hline $\begin{array}{l}\text { Accessory sperm count } \\
\text { and embryo recovery after } \\
\text { AI in-vivo }\end{array}$ & $\begin{array}{l}\text { Evaluation of fertilization rates, the proportion of normal } \\
\text { embryos and number of accessory sperm give information about } \\
\text { the capability of spermatozoa for oocyte recognition, oocyte } \\
\text { binding and penetration and embryo development }\end{array}$ & $\begin{array}{l}\text { This test was also used with hetero- } \\
\text { spermic doses to identify the most } \\
\text { capable spermatozoa }\end{array}$ & $\begin{array}{l}\text { Ardon et al. 2003, Stahlberg et } \\
\text { al. 2000, Hammitt et al. } 1989\end{array}$ \\
\hline $\begin{array}{l}\text { Pregnancy rate and live } \\
\text { born piglets }\end{array}$ & $\begin{array}{l}\text { The ultimate information about sperm fertility is being delivered } \\
\text { by the percentage of pregnant sows or number of piglets by } \\
\text { themselves }\end{array}$ & & \\
\hline
\end{tabular}




\subsection{Gender preselection in animal breeding}

Gender preselection is one of the most sought reproductive technologies in the animal breeding industry. Already 2500 years ago Greek philosophers reported how the gender of progeny might be influenced (Betteridge 1984). The prediction or determination of gender can either be conducted post-conceptionally by examination of early embryo or fetal stages or pre-conceptionally in mammals by separation of $\mathrm{X}$ and $\mathrm{Y}$ chromosome bearing spermatozoa ( $\mathrm{X}$ and $\mathrm{Y}$ sperm). "Embryo-Sexing" is already being applied in farm animals, especially in cattle. The sexing is performed either by applying Polymerase Chain Reaction (PCR) or by in-situ Hybridisation with Y-Chromosome specific DNA probes (Herr et al. 1990, Levinson et al. 1992). Although embryo-sexing is already routinely conducted, sperm-sexing has got more advantages. Micromanipulation and the withdrawal of embryo cells are unnecessary. Sexed spermatozoa can improve the efficiency of breeding programs in important species significantly. Especially with gender related animal products or products that can be produced in a better quality and higher amount by one gender, inseminations with sex selected spermatozoa would be useful. The number of animals required to produce a certain amount of animal products could be optimized and the environmental pollution could be lowered. Examples for this would be meat and milk products in cattle and swine. In swine the required gender could be prepared for mating on the different levels of the breeding program. For fatting, female piglets are superior to the males with lower meat quality. Females are also superior in feed conversion ratio, daily gain rate (Niemann et al. 2003). Further, castration would be unnecessary as demanded from some European countries, where the use of castration will be outlawed and hence alternatives for producing higher numbers of females are required (Johnson et al. 2005a).

In cattle, the number of test matings to determine the breeding value could significantly be lowered without any loss in statistical power. On dairy farms preferentially female calves could be produced and likewise male calves on beef farms. 


\subsubsection{Methods of gender sperm sorting}

In the past many different methods to predetermine the gender of offspring by sorting spermatozoa have been evaluated. Table 5 provides an overview of the different parameters. However, only the Beltsville sperm sexing technology (BSST) has been shown to produce repeatable and reliable gender predetermined offspring.

Table 5: $\quad$ Overview on parameters used or predicted to separate $\mathrm{X}$ and $\mathrm{Y}$ chromosome bearing spermatozoa

\begin{tabular}{lll}
\hline Parameter & Difference & Author(s) \\
\hline \hline DNA & X Sperm $>$ Y & $\begin{array}{l}\text { Moruzzi 1979, Pinkel et } \\
\text { al. 1982 }\end{array}$ \\
\hline Size & X Sperm $>$ Y & Cui and Matthews 1993, \\
& & Cui 1997 \\
\hline Motility & Y faster than X & Ericsson et al. 1973 \\
\hline F-Body & Heterochromatic part & Barlow and Vosa 1970 \\
& on Y & \\
\hline H-Y Antigen & sperm surface & Hendriksen 1999 \\
\hline Protein & sperm surface & Hendriksen et al. 1996 \\
\hline Surface charge & X migrates to cathode & Kaneko et al. 1984 \\
\hline
\end{tabular}

\subsubsection{Beltsville Sperm Sexing Technology}

The sorting of spermatozoa into separate populations of X-and Y-bearing sperm based on DNA requires a flow cytometer. Sperm DNA has to be labelled with the fluorescent dye Hoechst 33342 (2'-(4-ethoxyphenyl)-5-(4-methyl-1-piperazinyl)2',5'-bi-1H-binzimidazole 3 HCL). Hoechst 33342 (H33342) is a live-cell stain that permeates the cell membrane and binds selectively to A-T base pairs along the minor groove of dsDNA. H33342 usually is excited with the 351 or $364 \mathrm{~nm}$ UV light produced by an argon-ion laser (Seidel and Garner 2002). The slightly higher DNA content in X-chromosome bearing sperm cells results in a stronger fluorescent-signal 
compared with Y-chromosome bearing sperm. Sorting purity ranges normally between $90 \%$ to $98 \%$ (Johnson 2000) using high speed flow cytometers.

Nowadays spermatozoa of the most species can be sorted with high purity if the difference in DNA content is at least 3\%, requiring a correct sperm alignment in front of the laser and uniform labelling. The efficiency of sex sorting can be improved by adding the food dye FD\&C\#40. This dye exclusively stains spermatozoa with compromised membrane integrity and reduces the fluorescent signal of Hoechst 33342. It is therefore possible to exclude such damaged spermatozoa during sorting (Johnson and Welch 1999).

Johnson and Clarke (1988) showed the fertility of flowcytometric sorted sperm heads for the first time by injecting them into the cytoplasm of hamster oocytes. The first progeny out of sexed sperm after surgically inseminated of rabbits were derived by Johnson et al. (1989). The kittens did not show any morphological or genetic damages. From does inseminated with sorted X-bearing sperm, 94\% of the offspring born were females. From does inseminated with sorted Y-bearing sperm from the same ejaculates, $81 \%$ of the offspring were males. At first a broader use of sexed spermatozoa was not possible due to low sorting capacity. Today modified highspeed flow cytometer are used for sperm sexing. The modifications consist of a forward fluorescence detector in place of the light scatter detector that is standard in orthogonal configured flow systems. This is necessary in order to collect the fluorescent light from both the edge of the sperm $\left(90^{\circ}\right)$ as well as from the flat side $\left(0^{\circ}\right)$ of the sperm. By means of electronic gating, one can collect edge fluorescence and eliminate much of the variability associated with differential fluorescence, thereby resolving the two populations. The second modification as originally designed, incorporates a bevelled sample injection needle to replace the usual cylindrical sample injection needle common to cell sorters. This bevel at the exit tip of the needle is designed to produce a flat ribbon type sample-sheath stream, which orientates the paddle shaped heads of the sperm cells to align them within the stream, so that as the spermatozoa pass the laser beam, a high proportion will be facing the beam in the proper plane. A significant improvement in the needle modification aspect was reported by Rens et al. (1998): the tip of the flow cell was remodelled to provide 2-3 times the orientation capability of the needle system. An elliptical shape 
was modelled into the interior nozzle tip just above the exit orifice. The orienting tip of the nozzle brings the orienting action much closer to the laser beam detection system, thus increasing the orienting efficiency. Sperm sorters in use at the present time have incorporated the orienting tip design (Johnson and Welch 1999). XY. Inc. $\left(\mathrm{XY}^{\circledR}\right.$ Sex Selection Technology and Services, Fort Collins, CO, USA) is furthermore selling sperm sorters with their own tip (Cyto-Nozzle ${ }^{\circledR}$ ), which is an improved modification of the nozzle designed by Johnson.

The modified flow cytometer is essential for attaining separate populations of X-and Y-chromosome bearing living sperm (Johnson et al. 1989) on a repeatable basis. The modifications are also essential for reanalyzing sorted sperm for DNA to determine the proportions of X- or Y-sperm in a given sorted sample (Welch and Johnson 1999, Johnson et al. 1987). Differentiation of the amount of DNA present in the X- and Ychromosome bearing sperm for sorting can be done on virtually all commercial cell sorters that have been manufactured in the past 30 years if they have been modified as described. The only aspect (in addition to improved optics) that is variable, is the rate of sperm being sorted and the subsequent sexed sperm throughput.

Figure 3 shows the principle of sex sorting mammalian spermatozoa in a flowcytometer. 
Figure 2: $\quad$ Principle of a flowcytometer for sex sorting mammalian spermatozoa (modified Rath et al. 1996)

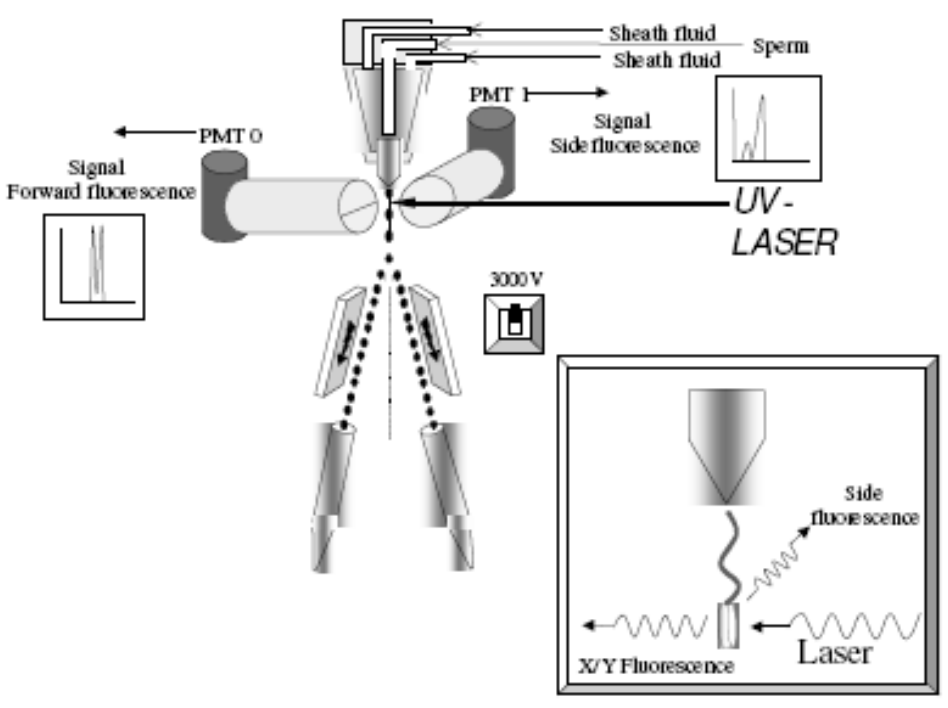

For the process of sex sorting spermatozoa, the semen is diluted and incubated with the fluorescent dye Hoechst 33342 for approximately one hour at $35^{\circ} \mathrm{C}$. The incubation assists the penetration of the stain through the membrane. Uniform stain penetration is essential to minimize stain variation and helps to reduce the number of cells not being properly recognized by the system during the sperm separation. The result of proper processing is improved efficiency of sorting.

In the flow cytometer spermatozoa are carried with the sheath fluid to a piezo electric crystal undulating approximately 65.000 times/second, which breaks the stream into droplets at a particular point in time. The location of the last-attached droplet in the stream is highly controllable. Only droplets carrying a single cell are included into the sort decisions. Johnson et al. (2000) described PBS with 0,1\% BSA as a carrier medium. Based on the difference of the dye related fluorescence signal sperm droplets are charged differently and are separated in the subsequent electrostatic field. The droplets are being collected in two collection tubes.

Only oriented sperm cells showing a defined DNA depended fluorescent signal are included in the sorting process (Rath et al. 1996). 


\subsubsection{Reanalysis}

The validation of the sorted semen samples can be performed immediately after sorting either by reanalysis in the sorter (Welch and Johnson 1999), by fluorescence in situ hybridization (Kawarasaki et al. 1998) or by PCR (Welch et al. 1995). Sort reanalysis for DNA has the advantage over FISH and PCR, since both techniques may take up to 3 to $4 \mathrm{~h}$, whereas reanalysis in the sorter requires less than 40 minutes. For a reanalysis in the flowcytometer 100.000 spermatozoa are taken. The cells are sonicated in order to remove the tails and Hoechst 33342 is added at tenfold concentration of the original concentration to maintain staining uniformity. The sperm cells are not sorted but analyzed at a very low speed to maximize orientation. DNA difference and histograms are analyzed by curve fitting to double Gaussian peaks (Johnson et al. 1987).

\subsubsection{Influence of flow cytometry on spermatozoa}

The fertility of sex sorted spermatozoa is lower compared to unsorted semen (Seidel et al. 1999, Buchanan et al. 2000). In trials of Doyle et al. (1999) and Seidel et al. (1999) the pregnancy rates of animals fertilized with sexed semen where $20 \%$ to $40 \%$ lower as the controls.

During sorting spermatozoa are exposed to different stress factors like high dilution, hydrodynamic pressure, UV light exposure and labelling with a critical dye (Johnson 2000). So far, the electric charge and the passage through the electro-static field seems to significantly affect motility (Garner 2006, Klinc and Rath 2007). However, besides reduced fertilizing capacity no changes have been identified so far, that would be critical for the use of sex sorted spermatozoa, especially no significant DNA modification could be identified (Parrilla et al. 2004).

It is accepted that sperm membranes change their patterns into the direction of capacitation. This however, is more a dilution effect that diminishes the presence of seminal plasma components known to be decapacitative. Small amounts of seminal plasma in the sheath fluid and in the collection medium allow an almost complete decapacitation. (Maxwell et al. 1996, Maxwell et al. 1998, Knöppel 2001). But the addition of $10 \%$ seminal plasma may have a negative effect on development rates 
after IVF due to the decapacitating factors in the seminal plasma (Maxwell and Johnson 1997, Maxwell et al. 1998). However, boar sperm showed no reduced fertilization rates after IVF after the addition of $1 \%$ seminal plasma to the collection media (RATH, unpublished)

The addition of egg yolk to the collection media is also a prerequisite to maintain sperm viability after sorting (Johnson et al. 1989, Johnson 1991).

Johnson et al. (2005a) reported that an estimated many as 30.000 offspring, mostly cattle, have been produced in the past with sex sorted spermatozoa. Commercial application of sex sorted spermatozoa is practiced in cattle but not in the swine industry because of the large numbers of sperm that are required to achieve pregnancies.

The percentage of motile sperm cells is reduced by dilution with the sheet fluid (Ashworth et al. 1994). In addition to the osmotic effects, the high dilution of sperm cells obviously removes natural antioxidants and other useful substances descending from the seminal plasma, which are essential for the fertilizing capability of the spermatozoa (Ashworth et al. 1994).

The sorting process itself causes more alterations of the sperm membrane compared to spermatozoa that were only diluted, but not stained with Hoechst 33342 and sorted. The viability and membrane integrity of boar and ram sperm were reduced after sorting (Maxwell and Johnson 1997).

Preservation of maximal viability of sex sorted spermatozoa has not been fully achieved for the application for artificial insemination so far. The lowered viability is based on the progressive status of membrane maturation of the spermatozoa that were sorted. Maxwell et al. (1998) found that 55-65\% of the sperm cells were already capacitated after flow sorting and $20-30 \%$ were already acrosome reacted. The precapacitation of sorted sperm cells was also described by Rath et al. (1997). In their trials treatments for capacitation of sperm cells for In-Vitro-Fertilisation were not necessary (Pursel and Johnson 1975b). Parilla et al. (2001) noticed a hypermotility of flowcytometrically sorted sperm cells also indicating a progressive capacitation status. Further stress for the semen cells arises during centrifugation in order to remove the sheath fluid (Maxwell et al. 1998).

Although there is no direct evidence that flow cytometrical sperm sorting causes lipid peroxidation, some reports raise some critical aspects. For flow cytometrical 
sorting the spermatozoa have to be incubated with Hoechst 33342 for 1-1.5 hours, at a temperature of $34-37^{\circ} \mathrm{C}$. At similar temperatures in mouse and rabbit spermatozoa the activation of high levels of energy for peroxidation processes has been detected (Alvarez and Storey 1985). Further the analysis of single spermatozoa during sorting demands a high dilution and consequently a concentration of cells by centrifugation after the sorting process. The natural defence against oxidation provided by seminal plasma is diminished by a high dilution during sorting with the sheath fluid. Addition of seminal plasma to samples during and after sorting has shown to have protective effects on the viability of spermatozoa (Maxwell et al. 1996). Centrifugation after sorting causes an increase in lipid peroxidation itself (Shekarriz et al. 1995). And finally, spermatozoa can be protected against lipid peroxidation during sorting. Antioxidant substances like Catalase have been used successfully for protection of bull spermatozoa during sorting and cryopreservation (Askari et al. 1994b, Beconi et al. 1993, Calamera et al. 2001, Bilodeau et al. 2002, Klinc 2005).

\subsubsection{Cryopreservation of flow cytometrical sorted spermatozoa}

Assuming a flow cytometer runs for 24 hours, 250 to 350 million of sexed spermatozoa for each sex with a purity of about $90 \%$ can be produced. The regular intracervical insemination in pigs requires at least 1 billion spermatozoa for each service. Due to the imprecise heat detection most animals have to be inseminated twice within 12 to 24 hours (Reed 1982, Hofmo 1991, Crabo and Dial 1992, Flowers and Esbenhade 1993, Steverink et al. 1999). Even if deep intrauterine insemination with low doses would be used to inseminate synchronized sows, a single sperm dose of $50 \times 10^{6}$ would be required. (Bathgate 2004, Grossfeld et al. 2005). This sperm dose has to be readily available at the farm at the right time for insemination. Other, more invasive technologies that only require a minimum number of spermatozoa for fertilization can be used as well: Johnson et al. (1991, Johnson et al. 2000) used fresh and frozen/thawed sex-sorted spermatozoa for surgical AI into the oviducts. Rath et al. (1997) successfully produced piglets with IVF/ET and surgical AI with only 400.000 sperm cells per $\mathrm{ml}$ of fertilizing media or AI respectively. Probst and Rath (2003) used ICSI to fertilize oocytes with sex sorted spermatozoa and achieved 
thirteen piglets from four sows. However these techniques have the disadvantage that they require surgical insemination.

It would therefore be useful to be able to store sex sorted semen for an extended period and to be able to transport the semen easily. This could be done by the cryopreservation of sex sorted spermatozoa.

Up until now, there are only a few reports about successful deep freezing of sex sorted boar spermatozoa. Johnson et al. (2000) were able to establish pregnancies after laparoscopic insemination with sex sorted and frozen semen that resulted in the birth of two piglets. They estimated that up to $30 \%$ of the sperm cells were able to survive sorting and freezing according to the motility of the spermatozoa. Bathgate et al. (2005) used sex-sorted frozen/thawed semen for in-vitro fertilization. They were able to establish pregnancies but did not get any piglets. Deep intrauterine inseminations (Martinez et al. 2001) with sexed and frozen/thawed spermatozoa in another trial resulted in one pregnancy (Bathgate 2004). The cryopreservation of sorted spermatozoa of cattle is commercially used and has been successful in other species as well, as reviewed by Garner et al. (2006) and others (Maxwell et al. 2004, Seidel 2003, Klinc 2005).

\subsection{Conclusions of the review of the current literature}

The use of sex sorted boar semen is of great significance for the animal industry. Restricted amounts of flow cytometrically sorted spermatozoa are available. The available spermatozoa are damaged during the sorting process, which leads to a compromised fertility.

The improvement of cryo-preservation of boar spermatozoa is the centre of many research efforts. Improvements have been gained with the design of freezing and thawing protocols, the development of packaging units, the composition of semen diluents and more recently with the addition of antioxidants to these diluents.

The research of the current work aims to improve the cryo-preservation of boar spermatozoa in common and sex sorted boar spermatozoa in particular. 


\section{CHAPTER 1: Quality assessment of frozen/thawed boar semen against individual freezing curves in the presence of antioxidants}

\subsection{Introduction}

Although cryo-preservation of boar semen for artificial insemination (AI) was developed some 35 years ago it still hampers to produce sufficient pregnancies with acceptable litter sizes. Even with excessive numbers of spermatozoa (5-6 x 10 $)$ thawed semen does not reach the fertility level of AI with fresh or cooled semen and represents the major limitation to its application in commercial AI programmes (Roca et al. 2006b). In an effort to improve the semen quality after freezing and thawing of boar semen two approaches were made. The first experiment evaluated the effect of three antioxidants (Pyruvate, Catalase and Mercaptoethanol) that principally act as ROS scavenger in cooling and freezing media (Klinc 2005) and in the second experiment three different freezing curves for individual boars were tested in the presence of these three antioxidants.

Cryo-preservation and the involved sperm processing have been described to support the creation of reactive oxygen species (ROS) (Alvarez and Storey 1985, Alvarez and Storey 1992). Porcine sperm membranes contain a relatively high proportion of polyunsaturated fatty acids, which decrease significantly during cryo-preservation, indicating lipid peroxidation (Cerolini et al. 2001). Lipid peroxidation has been correlated to exposure of spermatozoa to ROS and excessive ROS formation during cryopreservation has been associated with a decrease in the function of thawed spermatozoa (Chatterjee et al. 2001). Several antioxidants have been shown to improve the viability and functionality of cryopreserved boar spermatozoa. These include BHT, catalase (Roca et al. 2004), superoxide dismutase (Roca et al. 2005b, Bathgate 2004), Trolox (Pena et al. 2003b, 2004b) and other antioxidants. A combination of antioxidants has successfully been integrated in cryo-preservation of bull spermatozoa (Klinc 2005), where it improved sperm motility, viability and membrane integrity (Klinc et al. 2007, Klinc and Rath 2007). The goal of this 
experiment was therefore to test if, Catalase and Mercaptoethanol in the presence of Pyruvate allow to improve sperm quality of cryo-preserved boar spermatozoa. Sperm motility and its resistance against incubation at body temperature, sperm morphology and membrane integrity were criteria to assess possible effects.

Roca et al. (2006b) reported that optimal sperm cryo-preservation does not only depend on the cryo-preservation methodologies, but also on the individual variation among boars to sustain cryo-injury. Further, Medrano et al. (2002) described the influence of different cooling curves on the survival of spermatozoa from individual boars. The aim of the second study was therefore to test whether an optimal freezing curve can be set for individual boars when ROS scavengers are present during the freezing process.

\subsection{Material and methods}

\subsubsection{Freezing of boar semen in the presence of ROS scavengers}

\subsubsection{Processing of semen}

Semen was collected twice weekly from four boars with proven fertility. Animals were housed at the Sydney University Research Farm at Camden, Australia, using the gloved-hand-method. About $50 \mathrm{ml}$ of the sperm-rich fraction were collected in a thermos receptacle in collection bags (Minitube of Australia, Sebastopol, Australia) and the Bulbourethral secretion was separated by a filter included in the collection bag. Directly after collection the semen was diluted with pre-warmed $\left(38^{\circ} \mathrm{C}\right)$ Androhep $^{\mathrm{TM}}$ semen extender (Minitube of Australia, Sebastopol, Australia) (1:1, $\mathrm{v} / \mathrm{v})$. Motility of the samples was checked on a warming stage under a phase contrast microscope (Olympus CX 20, Olympus) at 100 x magnification. Semen was filled in pre-warmed $50 \mathrm{ml}$ plastic tubes (Greiner Bio-One, Tokyo) wrapped in a paper towel and transported to the laboratory in a cooling box within one hour at $15^{\circ} \mathrm{C}$. Sperm concentration was determined in an improved Neubauer haemocytometer. An aliquot of $50 \mu 1$ was fixed in $500 \mu 1$ Glutaraldehyde-solution (3\% in PBS, Sigma, St.Louis, MO, USA) to examine the morphology under a phase contrast microscope (Olympus CX 41, Olympus) at 1000x magnification under oil emersion. At least 200 
spermatozoa were examined. The semen samples were then diluted with Androhep ${ }^{\mathrm{TM}}$ to a concentration of $4 \times 10^{7}$ spermatozoa per $\mathrm{ml}$ in $15 \mathrm{ml}$ centrifugation tubes (Greiner Bio-One, Tokyo, Japan) .

A computer assisted sperm analysis (CASA) was made in a Hamilton-Thorne Sperm analyser (Hamilton-Thorne, Biosciences, Beverly, MA, USA) using $15 \mu 1$ of the diluted semen. Semen was then centrifuged for $10 \mathrm{~min}$ at $800 \mathrm{x} \mathrm{g}$ in a cooling centrifuge (IEC Centra-7R, International Equipment Company, MN, USA) and the remaining sperm pellet was re-suspended with one of the extenders to be tested. Cryo-preservation was performed according to the Westendorf-protocol (Westendorf et al. 1975).

\subsubsection{Experimental design}

After centrifugation, split samples of semen were submitted to either one of three different treatments. Pellets were re-suspended with cooling extender $(20 \%$ egg yolk, $80 \%$ Lactose-solution $11 \%, \mathrm{v} / \mathrm{v}$ ) and extended to a concentration of $4 \times 10^{7}$ spermatozoa $/ \mathrm{ml}$.

In treatment group A the cooling extender contained $12.3 \mathrm{IU} / \mathrm{ml}$ Catalase, $1 \mathrm{mMol}$ Na-Pyruvate and $53 \mu \mathrm{Mol}$ Mercaptoethanol per ml (all from Sigma, St. Louis, MO, USA). In treatment group B the cooling extender contained $200 \mu \mathrm{mol}$ of the Vitamin-E-Analogue Trolox (6-hydroxy - 2,5,7,8-tetramethylchroman -2-carboxylic acid, Trolox ${ }^{\mathrm{TM}}$, Sigma, St.Louis, MO, USA). Group $\mathrm{C}$ served as control and contained neither antioxidants nor Pyruvate.

After re-suspension and thorough mixing, semen was cooled to $5^{\circ} \mathrm{C}$ within 2 hours. Thereafter in a cooling room, semen was slowly mixed with freezing extender, consisting of $92.5 \mathrm{ml}$ of cooling extender, $6 \mathrm{ml}$ glycerol and $1.5 \mathrm{ml}$ Equex STM (Nova Chemicals Sales Inc., Scituate, MA, USA). Two parts of semen to one part of freezing extender where mixed, giving a final glycerol concentration of $2 \%$. The final sperm concentration was $2.67 \times 10^{7}$ spermatozoa $/ \mathrm{ml}$. The samples were then loaded in $0.5 \mathrm{ml}$ straws (IMV, L'Aigle, France) and transferred to the chamber of a programmable freezer (Planer Products Kryo 10, Series III; Planer Products Ltd., Sunbury, Middlesex, UK). The cooling rate was as follows: $-3^{\circ} \mathrm{C} / \mathrm{min}$ from +5 to $6^{\circ} \mathrm{C}$, one minute holding time at $-6^{\circ} \mathrm{C}$ and thereafter $-30^{\circ} \mathrm{C} / \mathrm{min}$ to $-140^{\circ} \mathrm{C}$. The frozen straws were then plunged in liquid nitrogen $\left(\mathrm{LN}_{2},-196^{\circ} \mathrm{C}\right)$ and stored until 
thawing. For post-thawing semen evaluation the samples were removed from the $\mathrm{LN}_{2}$ and thawed in a water bath at $38^{\circ} \mathrm{C}$ for $30 \mathrm{~s}$.

\subsubsection{Analysis of thawed semen}

The thawed straws were emptied in $5 \mathrm{ml}$ thawing tubes (Greiner Bio-One, Tokyo, Japan) kept in a water bath at $38^{\circ} \mathrm{C}$. An aliquot of $120 \mu 1$ was put in a second tube containing $240 \mu \mathrm{l}$ Androhep ${ }^{\mathrm{TM}}$ and kept at $38^{\circ} \mathrm{C}$ until evaluation. The motility of the frozen/thawed semen was analyzed $10 \mathrm{~min}, 1 \mathrm{~h}, 2 \mathrm{~h}, 3 \mathrm{~h}$ and $6 \mathrm{~h}$ after thawing under a phase-contrast microscope (Olympus CX 41, Olympus, Japan) equipped with a heating plate (Minitüb, Tiefenbach, Germany) at $38^{\circ} \mathrm{C}$. Two drops and at least three fields per drop were analysed in each sample at 100x magnification.

For analysis of sperm morphology an aliquot of $120 \mu 1$ thawed semen was mixed with $200 \mu 1$ Glutaraldehyde-solution. Morphological abnormalities and acrosome integrity were analysed under a phase-contrast microscope (Olympus CX 41, Olympus, Japan) at $1000 x$ magnification.

Membrane integrity and their functional status (acrosome reaction) were analysed flow cytometrically applying a triple staining method with SYTO-17/FITC-PNA/PI (Garner et al. 1999, Krienke 2003). After thawing, samples were diluted (1:2, v/v) right before staining to a final concentration of $5 \times 10^{6}$ spermatozoa/ml with Androhep $^{\mathrm{TM}}$.

Thereafter, $500 \mu 1$ of diluted semen were stained with $2 \mu 1$ SYTO-17'M $(0,5 \mathrm{mM}$; from Molecular Probes), $4 \mu 1$ PI (2,4 mM; Sigma Aldrich Chemicals) and 5 $\mu 1$ FITC-PNA $(100 \mu 1 / \mathrm{ml}$ DPBS; Sigma Aldrich Chemicals). Samples were mixed and incubated in the dark for $15 \mathrm{~min}$ at $38^{\circ} \mathrm{C}$ in an incubator (Thermoline TEI-13G, Thermoline Scientific Equipment Pty. Ltd., Smithfield, NSW, Australia). All samples were analyzed with a FACScan ${ }^{\mathrm{TM}}$ flow cytometer (Becton Dickinson) equipped with an air-cooled Argon-Ion-Laser with a wavelength of $488 \mathrm{~nm}$ and $15 \mathrm{~mW}$ laser power. For the measurements the filters FL-1 $(530 / 30 \mathrm{~nm})$ for green fluorescent and FL-3 (650LP $\mathrm{nm})$ for red fluorescent were used. Data-analysis was performed with the Cellquest $^{\mathrm{TM}}$-Software (Becton Dickinson) on a Power Mac G4-Computer (Apple Inc.). For sample analysis uniform settings were used. The debris of the egg yolk extender was gated out according to the method developed by NAGY et al. (2003). During evaluation sperm heads were divided into four groups according to their 
plasma membrane integrity and acrosomal integrity: sperm with intact membrane and intact acrosome (orange staining, SYTO-17+/PNA-/PI-), membrane damaged sperm with intact or completely lost acrosome (red staining, SYTO-17-/PNA-/PI+), membrane damaged and acrosome reacted sperm (red and green staining, SYTO-17$/ \mathrm{PNA}+/ \mathrm{PI}+$ ) and membrane intact and acrosome reacted sperm (orange and green staining, SYTO-17+/PNA+/PI-). The delimitation of sperm groups was done subjectively with the Cellquest ${ }^{\mathrm{TM}}$ Software (Becton Dickinson). At least $1 \times 10^{4}$ spermatozoa were analyzed per sample.

\subsubsection{Freezing of boar semen following different freezing curves}

\subsubsection{Processing of semen}

Semen was processed and tested for quality changes before freezing as described above. The cooling and freezing extender contained $12.3 \mathrm{IU} / \mathrm{ml}$ Catalase, $1 \mathrm{mMol}$ Na-Pyruvate and $53 \mu \mathrm{Mol}$ Mercaptoethanol per ml.

\subsubsection{Experimental design}

After loading the semen into straws samples were submitted to either one of the following three freezing curves (Table 6) using a programmable freezer (Planer Products Kryo 10, Series III; Planer Products Ltd., Sunbury, Middlesex, UK).

Table 6: $\quad$ Protocol of three different freezing curves

\begin{tabular}{|c|c|c|}
\hline Short freezing protocol & Medium freezing protocol & Long freezing protocol \\
\hline Start temperature $+4.0^{\circ} \mathrm{C}$ & Start temperature $+4.0^{\circ} \mathrm{C}$ & Start temperature +4.0 !C \\
\hline Cooling rate $-6^{\circ} \mathrm{C} / \mathrm{min}$ & Cooling rate $-3^{\circ} \mathrm{C} / \mathrm{min}$ & Cooling rate $-3^{\circ} \mathrm{C} / \mathrm{min}$ \\
\hline to $-5^{\circ} \mathrm{C}$ & to $-6^{\circ} \mathrm{C}$ & to $-6^{\circ} \mathrm{C}$ \\
\hline \multirow{3}{*}{$\begin{array}{c}\text { Freezing rate }-40^{\circ} \mathrm{C} / \mathrm{min} \\
\text { to }-80^{\circ} \mathrm{C} \\
\end{array}$} & $\begin{array}{l}\text { Holding time of } 60 \mathrm{~s} \text { at } \\
\qquad-6^{\circ} \mathrm{C}\end{array}$ & $\begin{array}{l}\text { Holding time of } 60 \mathrm{~s} \text { at } \\
-6^{\circ} \mathrm{C}\end{array}$ \\
\hline & & \\
\hline & $\begin{array}{l}\text { Freezing rate }-50^{\circ} \mathrm{C} / \mathrm{min} \text { to }- \\
\qquad 140^{\circ} \mathrm{C}\end{array}$ & $\begin{array}{l}\text { Freezing rate }-30^{\circ} \mathrm{C} / \mathrm{min} \text { to }- \\
\qquad 140^{\circ} \mathrm{C}\end{array}$ \\
\hline \multicolumn{3}{|l|}{ Holding time of $30 \mathrm{~s}$ at $-80^{\circ} \mathrm{C}$} \\
\hline \multicolumn{3}{|l|}{ Freezing rate $-50^{\circ} \mathrm{C} / \mathrm{min}$} \\
\hline to $-140^{\circ} \mathrm{C}$ & & \\
\hline
\end{tabular}


The frozen straws were then plunged in liquid nitrogen $\left(\mathrm{LN}_{2},-196^{\circ} \mathrm{C}\right)$ and stored until thawing.

For post-thaw semen evaluation samples were removed from $\mathrm{LN}_{2}$ and submitted to two different thawing protocols according to the corresponding freezing curves as shown in Table 7. Quality assessment was performed as described above.

Table 7: Different thawing protocols for boar semen according to freezing methods

\begin{tabular}{ccc}
\hline Short freezing protocol & Medium freezing protocol & Long freezing protocol \\
\hline \hline $12 \mathrm{~s}$ at $50^{\circ} \mathrm{C}$ & $30 \mathrm{~s}$ at $38^{\circ} \mathrm{C}$ & $30 \mathrm{~s}$ at $38^{\circ} \mathrm{C}$ \\
\hline
\end{tabular}

\subsubsection{Semen analysis}

The analyses of the thawed semen samples was conducted in the same way as described under 3.2.1.3.

\subsubsection{Statistical analysis}

Statistical analyses were performed with SIGMA STAT 2.03 for Windows (Jandel Scientific Cooperation, San Ragael, CA, USA). Effects of group treatment on the quality of the semen was analysed for normal distribution and tested with One-way ANOVA or ANOVA on Ranks. Significances were tested with the Tukey test. Data are expressed as percentages or means \pm SD. Differences were considered to be significant at $\mathrm{P}<0.05$. 


\subsection{Results}

\subsubsection{Freezing of boar semen in the presence of ROS scavengers}

During the experiment 36 ejaculates were collected from four boars. The estimated motility of the samples right after collection and dilution with Androhep ${ }^{\mathrm{TM}}$ was $88.9 \pm 2.1 \%$.

Motility after transport and cooling to $15^{\circ} \mathrm{C}$ was $89.1 \pm 6.6 \%$ motile and $62.0 \pm 8.3 \%$ progressively motile spermatozoa. The mean concentration of all ejaculates was $32.7 \pm 9.7 \times 10^{7}$ spermatozoa per ml. Fresh semen samples showed $6.7 \pm 3.6 \%$ morphologically abnormal spermatozoa and $97.3 \pm 2.3 \%$ of spermatozoa had a normal apical ridge (NAR).

Directly after thawing (0h) semen frozen with addition of Pyruvate, Catalase and Mercaptoethanol showed a significantly higher percentage of motile spermatozoa as compared to controls. Semen frozen in the presence of TROLOX showed the same motility pattern as in the control group $(45.9 \pm 18.8 \%)$ and the AO-Mix group. After $6 \mathrm{~h}$ of incubation semen frozen in the presence of Pyruvate, Catalase and Mercaptoethanol had a higher motility than the control group $(p<0.05)$ although the motility was very low in both groups and irrelevant for AI.

Table 8: $\quad$ Percentage of motile spermatozoa exposed to a $6 \mathrm{~h}$ thermo resistance test after thawing employing different antioxidants in the cooling and freezing extenders

\begin{tabular}{cccc}
\hline$\%$ & $\begin{array}{c}\text { AO-Mix } \\
\mathbf{X} \pm \text { SD }\end{array}$ & $\begin{array}{c}\text { Trolox } \\
\mathbf{X} \pm \text { SD }\end{array}$ & $\begin{array}{c}\text { Control } \\
\mathbf{X} \pm \text { SD }\end{array}$ \\
\hline \hline $\mathbf{0 ~ h}$ & $59.3 \pm 16.0^{\mathrm{bA}}$ & $54.1 \pm 17.8^{\mathrm{abA}}$ & $45.9 \pm 18.8^{\mathrm{aA}}$ \\
\hline $\mathbf{1 ~ h}$ & $48.6 \pm 23.9^{\mathrm{aA}}$ & $42.1 \pm 23.2^{\mathrm{aAC}}$ & $39.7 \pm 23.5^{\mathrm{aAC}}$ \\
\hline $\mathbf{2} \mathbf{~ h}$ & $35.6 \pm 24.7^{\mathrm{aAC}}$ & $23.6 \pm 23.5^{\mathrm{aBC}}$ & $30.1 \pm 23.4^{\mathrm{aBCD}}$ \\
\hline $\mathbf{3 ~ h}$ & $17.1 \pm 15.8^{\mathrm{aBC}}$ & $13.4 \pm 12.5^{\mathrm{aBD}}$ & $13.2 \pm 12.6^{\mathrm{aBD}}$ \\
\hline $\mathbf{6} \mathbf{~ h}$ & $3.5 \pm 3.3^{\mathrm{bB}}$ & $2.2 \pm 2.4^{\mathrm{abBD}}$ & $1.7 \pm 1.6^{\mathrm{aB}}$ \\
\hline $\begin{array}{c}\mathrm{a}: \mathrm{b} \mathrm{p} \leq 0.05 \text { at same time after thawing } \\
\mathrm{A}: \mathrm{B} \mathrm{p} \leq 0.05 \text { within one treatment group }\end{array}$
\end{tabular}


The percentage of morphological abnormal spermatozoa was evaluated directly after thawing and is summarized in Table 9.

Table 9: $\quad$ Percentage of morphologically abnormal spermatozoa directly after thawing

\begin{tabular}{cccc}
\hline$\%$ & $\begin{array}{c}\text { AO-Mix } \\
\mathbf{X} \pm \text { SD }\end{array}$ & $\begin{array}{c}\text { Trolox } \\
\overline{\mathrm{X}} \pm \text { SD }\end{array}$ & $\begin{array}{c}\text { Control } \\
\overline{\mathrm{X}} \pm \mathrm{SD}\end{array}$ \\
\hline $\begin{array}{c}\text { normal } \\
\text { apical ridge (NAR) }\end{array}$ & $34.1 \pm 7.4$ & $33.6 \pm 7.8$ & $32.8 \pm 5.5$ \\
\hline $\begin{array}{c}\text { dissolving } \\
\text { acrosome }\end{array}$ & $28.4 \pm 6.1$ & $30.1 \pm 10.7$ & $29.26 \pm 9.3$ \\
\hline lost acrosome & $37.6 \pm 7.4$ & $36.3 \pm 12.6$ & $38.0 \pm 8.0$ \\
\hline gross morphology & $66.8 \pm 6.9$ & $66.9 \pm 7.6$ & $67.9 \pm 5.6$ \\
\hline other & $2.2 \pm 2.2^{\mathrm{a}}$ & $1.5 \pm 0.9^{\mathrm{ab}}$ & $1.4 \pm 0.8^{\mathrm{b}}$ \\
\hline abnormalities & & & \\
\hline a:b $\mathrm{p} \leq 0.05$ between treatment groups & & & \\
\hline
\end{tabular}

Frozen/thawed spermatozoa were evaluated flowcytometrically at $0 \mathrm{~h}$ and $2 \mathrm{~h}$ after thawing. Table 10 shows the results of the triple staining.

As shown in table 10 there were no significant differences between groups, but in eleven of twelve groups the values differed significantly within a group after $2 \mathrm{~h}$ incubation. Only the percentage of vital and acrosome reacted spermatozoa differed significantly after $2 \mathrm{~h}$ incubation with the sample frozen with the AO-Mix showing a lower percentage than the control group $(0.8 \pm 0.2 \%$ vs. $0.9 \pm 0.3 \%)$. 
Table 10: $\quad$ Results of the flowcytometrical evaluation of membrane integrity and acrosome reaction of frozen/thawed spermatozoa applying SYTO17/FITC-PNA/PI $0 \mathrm{~h}$ and $2 \mathrm{~h}$ after thawing

\begin{tabular}{|c|c|c|c|c|}
\hline$(\%)$ & $\begin{array}{l}\text { hours } \\
\text { after } \\
\text { thawing }\end{array}$ & $\begin{array}{c}\text { AO-Mix } \\
\bar{X} \pm \text { SD }\end{array}$ & $\begin{array}{l}\text { Trolox } \\
\text { X } \pm \text { SD }\end{array}$ & $\begin{array}{c}\text { Control } \\
\bar{X} \pm \mathrm{SD}\end{array}$ \\
\hline \multirow{2}{*}{$\begin{array}{c}\text { viable } \\
\text { spermatozoa; intact } \\
\text { acrosome } \\
\end{array}$} & $0 \mathrm{~h}$ & $61.8 \pm 8.3^{\mathrm{A}}$ & $62.5 \pm 9.0^{\mathrm{A}}$ & $61.5 \pm 9.3^{\mathrm{A}}$ \\
\hline & $2 \mathrm{~h}$ & $57.0 \pm 7.7^{\mathrm{B}}$ & $56.9 \pm 9.2^{\mathrm{B}}$ & $54.8 \pm 10.3^{B}$ \\
\hline \multirow{2}{*}{$\begin{array}{c}\text { viable } \\
\text { spermatozoa; } \\
\text { acrosome reacted }\end{array}$} & $0 \mathrm{~h}$ & $0.4 \pm 0.5^{\mathrm{A}}$ & $0.4 \pm 0.2^{\mathrm{A}}$ & $0.4 \pm 0.2^{\mathrm{A}}$ \\
\hline & $2 \mathrm{~h}$ & $0.8 \pm 0.2^{\mathrm{aB}}$ & $0.8 \pm 2.5^{\mathrm{abB}}$ & $0.9 \pm 0.3^{\mathrm{bB}}$ \\
\hline \multirow{2}{*}{$\begin{array}{c}\text { membrane } \\
\text { damaged sperm; } \\
\text { acrosome intact }\end{array}$} & $\mathrm{Oh}$ & $28.5 \pm 6.74$ & $28.0 \pm 7.3^{\mathrm{A}}$ & $29.0 \pm 8.1^{\mathrm{A}}$ \\
\hline & $2 \mathrm{~h}$ & $31.5 \pm 6.0$ & $31.5 \pm 7.4^{\mathrm{B}}$ & $33.1 \pm 8.6^{\mathrm{B}}$ \\
\hline \multirow{2}{*}{$\begin{array}{c}\text { membrane } \\
\text { damaged sperm; } \\
\text { acrosome reacted }\end{array}$} & $0 \mathrm{~h}$ & $9.3 \pm 2.4^{\mathrm{A}}$ & $9.1 \pm 2.5^{\mathrm{A}}$ & $9.1 \pm 1.9^{\mathrm{A}}$ \\
\hline & $2 \mathrm{~h}$ & $10.7 \pm 2.6^{\mathrm{B}}$ & $10.8 \pm 2.5^{\mathrm{B}}$ & $11.2 \pm 2.5^{\mathrm{B}}$ \\
\hline
\end{tabular}

\subsubsection{Quality assessment of frozen/thawed boar semen against individual freezing speeds}

During the experiment six ejaculates were obtained from four boars. Table 11 shows the motility results directly after collection, and dilution, and after cooling to $15^{\circ} \mathrm{C}$ as evaluated with a computer assisted sperm analyzing (CASA) system. 
Table 11: $\quad$ Motility of fresh semen samples directly after collection and dilution and after cooling to $15^{\circ} \mathrm{C}$ as analyzed with CASA

\begin{tabular}{|c|c|c|c|c|c|}
\hline$(\%)$ & & $\begin{array}{c}\text { Boar A } \\
\text { X } \pm \text { SD }\end{array}$ & $\begin{array}{c}\text { Boar B } \\
\mathrm{X} \pm \text { SD }\end{array}$ & $\begin{array}{c}\text { Boar C } \\
\bar{X} \pm S D\end{array}$ & $\begin{array}{c}\text { Boar D } \\
\bar{X} \pm \text { SD }\end{array}$ \\
\hline $\begin{array}{c}\text { Motility } \\
\text { directly after } \\
\text { collection and } \\
\text { dilution (\%) }\end{array}$ & & $88.0 \pm 4.5$ & $90.0 \pm 0.0$ & $89.2 \pm 2.0$ & $90.0 \pm 0.0$ \\
\hline $\begin{array}{c}\text { Motility after } \\
\text { cooling to }\end{array}$ & $\begin{array}{c}\text { gross } \\
\text { motility }\end{array}$ & $88.8 \pm 4.0$ & $93.7 \pm 2.0$ & $92.0 \pm 2.5$ & $93.7 \pm 3.0$ \\
\hline $\begin{array}{c}15^{\circ} \mathrm{C}(\mathrm{CASA}) \\
(\%)\end{array}$ & $\begin{array}{c}\text { progressive } \\
\text { motility }\end{array}$ & $67.3 \pm 5.8$ & $76.7 \pm 2.3$ & $59.0 \pm 5.2$ & $66.8 \pm 5.2$ \\
\hline
\end{tabular}

The concentration of the semen samples $(n=6)$ from four boars after 1:2 dilution with Androhep ${ }^{\mathrm{TM}}$ as determined with a haemocytometer was $360.8 \pm 104.9 \times 10^{6}$ per $\mathrm{ml}$ for boar A, $514.2 \pm 161.2 \times 10^{6}$ per $\mathrm{ml}$ for boar B, $349.17 \pm 118.3 \times 10^{6}$ per $\mathrm{ml}$ for boar C and $535.3 \pm 117.8 \times 10^{6}$ per $\mathrm{ml}$ for boar D. Table 12 summarizes the results of the morphological evaluation of the fresh semen samples.

Table 12: $\quad$ Percentage of morphologically abnormal spermatozoa after Glutaraldehyd fixation (6 ejaculates from 4 four boars each) - $\underline{\text { Fresh }}$ semen samples

\begin{tabular}{cccccc}
\hline (\%) & $\begin{array}{c}\text { Boar A } \\
\overline{\mathrm{X}} \pm \mathrm{SD}\end{array}$ & $\begin{array}{c}\text { Boar B } \\
\overline{\mathrm{X}} \pm \mathrm{SD}\end{array}$ & $\begin{array}{c}\text { Boar C } \\
\overline{\mathrm{X}} \pm \mathrm{SD}\end{array}$ & $\begin{array}{c}\text { Boar D } \\
\overline{\mathrm{X}} \pm \mathrm{SD}\end{array}$ & $\begin{array}{c}\text { Total } \\
\overline{\mathrm{X}} \pm \mathrm{SD}\end{array}$ \\
\hline \hline $\begin{array}{c}\text { normal apical ridge } \\
(\mathrm{NAR})\end{array}$ & $96.6 \pm 0.6$ & $99.7 \pm 0.4$ & $97.6 \pm 0.9$ & $98.7 \pm 0.5$ & $98.2 \pm 1.3$ \\
\hline $\begin{array}{c}\text { dissolving acrosomes } \\
\text { lost } \\
\text { acrosomes }\end{array}$ & $1.9 \pm 0.6$ & $0.1 \pm 0.6$ & $0.9 \pm 0.9$ & $0.7 \pm 0.6$ & $1.0 \pm 0.8$ \\
\hline $\begin{array}{c}\text { other } \\
\text { abnormalities }\end{array}$ & $1.4 \pm 0.6$ & $0.2 \pm 0.4$ & $1.3 \pm 0.9$ & $0.6 \pm 0.5$ & $0.9 \pm 0.7$ \\
\hline $\begin{array}{c}\text { gross } \\
\text { morphology }\end{array}$ & $15.4 \pm 4.6$ & $11.4 \pm 8.0$ & $6.9 \pm 1.2$ & $4.4 \pm 1.4$ & $9.5 \pm 6.2$ \\
\hline
\end{tabular}


Directly after thawing the motility of the frozen/thawed sperm samples was evaluated in a thermo-resistance-test. Table 13-16 show the motility of the different freezing protocols for each boar.

There was no significant difference for boar A during the thermo resistance test in the percentage of motile spermatozoa between samples frozen in either one of the respective freezing protocols. However, there was a significant motility decrease in all treatment groups during the incubation period.

Table 13: $\quad$ Sperm motility of Boar A in a thermo-resistance-test of spermatozoa frozen and thawed according to one of three different freezing protocols

\begin{tabular}{cccc}
\hline$\%)$ & $\begin{array}{c}\text { Short } \\
\mathrm{X} \pm \mathrm{SD}\end{array}$ & $\begin{array}{c}\text { Medium } \\
\overline{\mathrm{X}} \pm \text { SD }\end{array}$ & $\begin{array}{c}\text { Long } \\
\overline{\mathrm{X}} \pm \text { SD }\end{array}$ \\
\hline \hline $0 \mathrm{~h}$ & $67.5 \pm 12.9^{\mathrm{A}}$ & $65.0 \pm 10.0^{\mathrm{A}}$ & $65.0 \pm 8.4^{\mathrm{A}}$ \\
\hline $1 \mathrm{~h}$ & $52.5 \pm 9.4^{\mathrm{A}}$ & $59.2 \pm 11.1^{\mathrm{A}}$ & $57.5 \pm 8.2^{\mathrm{A}}$ \\
\hline $2 \mathrm{~h}$ & $49.2 \pm 8.6^{\mathrm{B}}$ & $54.2 \pm 14.3^{\mathrm{A}}$ & $53.3 \pm 10.8^{\mathrm{A}}$ \\
\hline $3 \mathrm{~h}$ & $27.1 \pm 12.1^{\mathrm{B}}$ & $36.7 \pm 16.3^{\mathrm{B}}$ & $39.2 \pm 12.4^{\mathrm{B}}$ \\
\hline $6 \mathrm{~h}$ & $3.5 \pm 5.7^{\mathrm{B}}$ & $6.2 \pm 5.3^{\mathrm{B}}$ & $6.0 \pm 4.7^{\mathrm{B}}$ \\
\hline
\end{tabular}

$\mathrm{A}: \mathrm{B}: \mathrm{C} \mathrm{p} \leq 0.001$ within one treatment group

There was no significant difference for boar B during the thermo resistance test in the percentage of motile spermatozoa between samples frozen in either one of the respective freezing protocols, but the motility decreased significantly in all during groups over time. 
Table 14: $\quad$ Sperm motility of Boar B in a thermo-resistance-test of spermatozoa frozen and thawed according to three different freezing curves

\begin{tabular}{cccc}
\hline$(\%)$ & $\begin{array}{c}\text { Short } \\
\mathrm{X} \pm \mathrm{SD}\end{array}$ & $\begin{array}{c}\text { Medium } \\
\mathrm{X} \pm \mathrm{SD}\end{array}$ & $\begin{array}{c}\text { Long } \\
\mathrm{X} \pm \mathrm{SD}\end{array}$ \\
\hline \hline $0 \mathrm{~h}$ & $52.5 \pm 17.8^{\mathrm{A}}$ & $57.5 \pm 12.9^{\mathrm{A}}$ & $57.5 \pm 23.2^{\mathrm{A}}$ \\
\hline $1 \mathrm{~h}$ & $55.0 \pm 17.0^{\mathrm{A}}$ & $48.3 \pm 24.0^{\mathrm{A}}$ & $49.2 \pm 17.2^{\mathrm{A}}$ \\
\hline $2 \mathrm{~h}$ & $37.5 \pm 16.34^{\mathrm{A}}$ & $32.5 \pm 22.1^{\mathrm{B}}$ & $33.3 \pm 17.8^{\mathrm{A}}$ \\
\hline $3 \mathrm{~h}$ & $13.0 \pm 8.0^{\mathrm{B}}$ & $13.8 \pm 7.2^{\mathrm{C}}$ & $9.7 \pm 5.0^{\mathrm{B}}$ \\
\hline $6 \mathrm{~h}$ & $1.7 \pm 2.0^{\mathrm{B}}$ & $0.5 \pm 0.6^{\mathrm{D}}$ & $1.2 \pm 1.9^{\mathrm{B}}$ \\
\hline
\end{tabular}

$\mathrm{A}: \mathrm{B}: \mathrm{C}: \mathrm{D} \mathrm{p} \leq 0.001$ within one treatment group

Semen of boar C frozen with the "long" freezing curve showed a significant better sperm motility directly after thawing than samples frozen with the short curve $(66.7 \pm 8.2 \%$ vs. $43.3 \pm 10.8 \%)$. The groups frozen in different freezing protocols did not differ significantly from one to six hours after thawing and start of incubation, although the percentage of motile spermatozoa was always higher for the sample frozen in the long freezing curve. During the incubation the motility decreased significantly over time.

Table 15: $\quad$ Sperm motility of Boar C during a thermo-resistance-test of spermatozoa frozen and thawed according to three different freezing curves

\begin{tabular}{cccc}
\hline$(\%)$ & $\begin{array}{c}\text { Short } \\
\mathrm{X} \pm \mathrm{SD}\end{array}$ & $\begin{array}{c}\text { Medium } \\
\mathrm{X} \pm \text { SD }\end{array}$ & $\begin{array}{c}\text { Long } \\
\overline{\mathrm{X}} \pm \text { SD }\end{array}$ \\
\hline \hline $0 \mathrm{~h}$ & $43.3 \pm 10.8^{\mathrm{aA}}$ & $51.7 \pm 18.4^{\mathrm{A}}$ & $66.7 \pm 8.2^{\mathrm{bA}}$ \\
\hline $1 \mathrm{~h}$ & $32.5 \pm 8.2^{\mathrm{A}}$ & $47.5 \pm 15.7^{\mathrm{A}}$ & $57.5 \pm 11.3^{\mathrm{A}}$ \\
\hline $2 \mathrm{~h}$ & $21.7 \pm 15.7^{\mathrm{B}}$ & $35.8 \pm 16.6^{\mathrm{A}}$ & $52.5 \pm 9.4^{\mathrm{A}}$ \\
\hline $3 \mathrm{~h}$ & $11.7 \pm 7.5^{\mathrm{B}}$ & $28.3 \pm 16.6^{\mathrm{A}}$ & $37.5 \pm 12.1^{\mathrm{B}}$ \\
\hline $6 \mathrm{~h}$ & $1.2 \pm 1.9^{\mathrm{B}}$ & $2.0 \pm 2.0^{\mathrm{B}}$ & $6.8 \pm 4.8^{\mathrm{B}}$ \\
\hline
\end{tabular}

$\mathrm{a}: \mathrm{b} \mathrm{p} \leq 0.05$ at same time after thawing between treatment groups

$\mathrm{A}: \mathrm{B} \mathrm{p} \leq 0.05$ within one treatment group 
There was no significant difference for boar D during the thermo resistance test in the percentage of motile spermatozoa between samples frozen in either one of the respective freezing protocols but motility decreased significantly over time.

Table 16: $\quad$ Sperm motility of Boar D in a thermo-resistance-test of spermatozoa frozen and thawed according to three different freezing curves

\begin{tabular}{cccc}
\hline$\%)$ & $\begin{array}{c}\text { Short } \\
\overline{\mathrm{X}} \pm \mathrm{SD}\end{array}$ & $\begin{array}{c}\text { Medium } \\
\overline{\mathrm{X}} \pm \mathrm{SD}\end{array}$ & $\begin{array}{c}\text { Long } \\
\overline{\mathrm{X}} \pm \mathrm{SD}\end{array}$ \\
\hline \hline $0 \mathrm{~h}$ & $70.8 \pm 6.7^{\mathrm{A}}$ & $66.7 \pm 9.3^{\mathrm{A}}$ & $61.7 \pm 8.2^{\mathrm{A}}$ \\
\hline $1 \mathrm{~h}$ & $60.8 \pm 10.7^{\mathrm{B}}$ & $65.0 \pm 0.0^{\mathrm{A}}$ & $59.2 \pm 8.6^{\mathrm{A}}$ \\
\hline $2 \mathrm{~h}$ & $46.7 \pm 8.8^{\mathrm{C}}$ & $45.0 \pm 20.3^{\mathrm{B}}$ & $42.5 \pm 13.7^{\mathrm{B}}$ \\
\hline $3 \mathrm{~h}$ & $25.8 \pm 9.2^{\mathrm{D}}$ & $34.2 \pm 18.0^{\mathrm{C}}$ & $23.3 \pm 13.7^{\mathrm{B}}$ \\
\hline $6 \mathrm{~h}$ & $2.2 \pm 2.2^{\mathrm{E}}$ & $3.7 \pm 3.6^{\mathrm{D}}$ & $3.5 \pm 3.3^{\mathrm{B}}$ \\
\hline
\end{tabular}

$\mathrm{A}: \mathrm{B}: \mathrm{C}: \mathrm{D}: \mathrm{E} \mathrm{p} \leq 0.05$ within one treatment group

Table 17 shows the mean motility of all boars during the thermo resistances test in the percentage of motile spermatozoa between samples frozen in either one of the respective freezing protocols. There was no significant difference between the groups but the motility decreased significantly over time.

Table 17: Mean motility of all boars during the thermo resistances test in the percentage of motile spermatozoa between samples frozen in either one of the respective freezing protocols

\begin{tabular}{cccc}
\hline$(\%)$ & $\begin{array}{c}\text { Short } \\
\mathrm{X} \pm \text { SD }\end{array}$ & $\begin{array}{c}\text { Medium } \\
\mathrm{X} \pm \text { SD }\end{array}$ & $\begin{array}{c}\text { Long } \\
\mathrm{X} \pm \text { SD }\end{array}$ \\
\hline \hline $0 \mathrm{~h}$ & $58.5 \pm 16.5^{\mathrm{A}}$ & $60.2 \pm 13.8^{\mathrm{A}}$ & $62.7 \pm 13.2^{\mathrm{A}}$ \\
\hline $1 \mathrm{~h}$ & $50.2 \pm 15.5^{\mathrm{A}}$ & $55.0 \pm 16.2^{\mathrm{A}}$ & $55.8 \pm 11.8^{\mathrm{A}}$ \\
\hline $2 \mathrm{~h}$ & $38.8 \pm 16.3^{\mathrm{A}}$ & $41.9 \pm 19.3^{\mathrm{A}}$ & $45.4 \pm 15.0^{\mathrm{B}}$ \\
\hline $3 \mathrm{~h}$ & $19.5 \pm 11.4^{\mathrm{B}}$ & $28.3 \pm 16.8^{\mathrm{B}}$ & $27.4 \pm 16.1^{\mathrm{B}}$ \\
\hline $6 \mathrm{~h}$ & $2.1 \pm 3.3^{\mathrm{C}}$ & $3.1 \pm 3.8^{\mathrm{C}}$ & $4.4 \pm 4.3^{\mathrm{B}}$ \\
\hline
\end{tabular}


There were no significant differences between the groups in the percentage of morphological abnormal spermatozoa for boar A.

Table 18: $\quad$ Percentage of morphological abnormal spermatozoa of Boar A directly after thawing

\begin{tabular}{cccc}
\hline$(\%)$ & $\begin{array}{c}\text { Short } \\
\overline{\mathrm{X}} \pm \text { SD }\end{array}$ & $\begin{array}{c}\text { Medium } \\
\overline{\mathrm{x}} \pm \text { SD }\end{array}$ & $\begin{array}{c}\text { Long } \\
\overline{\mathrm{X}} \pm \text { SD }\end{array}$ \\
\hline \hline normal apical ridge & $34.8 \pm 6.7$ & $35.5 \pm 9.8$ & $25.7 \pm 10.0$ \\
$(\mathrm{NAR})$ & $26.2 \pm 6.7$ & $23.0 \pm 7.2$ & $29.9 \pm 11.8$ \\
\hline dissolving acrosomes & $39.0 \pm 6.6$ & $41.5 \pm 9.8$ & $44.4 \pm 9.9$ \\
\hline lost acrosomes & $2.0 \pm 1.0$ & $1.7 \pm 0.6$ & $1.7 \pm 1.2$ \\
\hline other abnormalities & $67.6 \pm 6.6$ & $66.2 \pm 9.9$ & $75.9 \pm 10.0$ \\
\hline gross morphology & & &
\end{tabular}

There were no significant differences between the groups in the percentage of morphological abnormal spermatozoa for boar B.

Table 19: $\quad$ Percentage of morphologically abnormal spermatozoa of Boar B directly after thawing

\begin{tabular}{cccc}
\hline$(\%)$ & $\begin{array}{c}\text { Short } \\
\overline{\mathrm{X}} \pm \text { SD }\end{array}$ & $\begin{array}{c}\text { Medium } \\
\overline{\mathrm{X}} \pm \text { SD }\end{array}$ & $\begin{array}{c}\text { Long } \\
\mathbf{X} \pm \text { SD }\end{array}$ \\
\hline $\begin{array}{c}\text { normal apical ridge } \\
(\mathrm{NAR})\end{array}$ & $26.7 \pm 8.5$ & $26.5 \pm 7.66$ & $24.5 \pm 5.8$ \\
\hline dissolving acrosomes & $32.1 \pm 9.5$ & $37.0 \pm 7.7$ & $32.9 \pm 5.7$ \\
\hline lost acrosomes & $41.2 \pm 8.2$ & $36.5 \pm 11.3$ & $42.6 \pm 6.9$ \\
\hline other abnormalities & $4.0 \pm 0.0$ & $1.3 \pm 0.6$ & $1.0 \pm 0.0$ \\
\hline gross morphology & $77.3 \pm 8.3$ & $74.8 \pm 7.08$ & $76.6 \pm 6.1$ \\
\hline Data differed not significantly & & &
\end{tabular}

There were no significant differences between the groups in the percentage of morphological abnormal spermatozoa for boar C. 
Table 20: $\quad$ Percentage of morphologically abnormal spermatozoa of Boar C directly after thawing

\begin{tabular}{cccc}
\hline$(\%)$ & $\begin{array}{c}\text { Short } \\
\mathrm{X} \pm \mathrm{SD}\end{array}$ & $\begin{array}{c}\text { Medium } \\
\mathrm{X} \pm \mathrm{SD}\end{array}$ & $\begin{array}{c}\text { Long } \\
\mathrm{X} \pm \mathrm{SD}\end{array}$ \\
\hline \hline $\begin{array}{c}\text { normal apical ridge } \\
(\mathrm{NAR})\end{array}$ & $24.5 \pm 9.3$ & $25.8 \pm 5.9$ & $31.7 \pm 9.3$ \\
\hline dissolving acrosomes & $29.9 \pm 7.3$ & $23.0 \pm 7.0$ & $31,2 \pm 10.3$ \\
\hline lost acrosomes & $45.6 \pm 11.6$ & $51.2 \pm 9.8$ & $37.6 \pm 8.9$ \\
\hline other abnormalities & $1.0 \pm 0.0$ & $1.0 \pm 0.0$ & $1.0 \pm 0.0$ \\
\hline gross morphology & $76.4 \pm 9.2$ & $75.1 \pm 5.8$ & $69.8 \pm 9.4$ \\
\hline not significantly different & & &
\end{tabular}

not significantly different

There were no significant differences between the groups in the percentage of morphological abnormal spermatozoa for boar D.

Table 21: $\quad$ Percentage of morphologically abnormal spermatozoa of Boar D directly after thawing

\begin{tabular}{cccc}
\hline$\%)$ & $\begin{array}{c}\text { Short } \\
\overline{\mathrm{X}} \pm \mathrm{SD}\end{array}$ & $\begin{array}{c}\text { Medium } \\
\overline{\mathrm{X}} \pm \mathrm{SD}\end{array}$ & $\begin{array}{c}\text { Long } \\
\mathrm{X} \pm \text { SD }\end{array}$ \\
\hline \hline $\begin{array}{c}\text { normal apical ridge } \\
(\mathrm{NAR})\end{array}$ & $32.3 \pm 7.2$ & $32.5 \pm 6.6$ & $28.8 \pm 5.9$ \\
\hline dissolving acrosomes & $27.3 \pm 7.2$ & $31.9 \pm 6.6$ & $24.7 \pm 5.9$ \\
\hline lost acrosomes & $40.4 \pm 6.3$ & $35.6 \pm 7.7$ & $46.5 \pm 5.6$ \\
\hline other abnormalities & $1.0 \pm 0.0$ & $3.0 \pm 0.0$ & $1.5 \pm 0.7$ \\
\hline gross morphology & $68.7 \pm 7.6$ & $70.5 \pm 7.2$ & $72.7 \pm 6.5$ \\
\hline
\end{tabular}

not significantly different 
Table 22 summarizes the morphological results for all boars directly after thawing. There were no significant differences between the treatment groups of all boars.

Table 22: $\quad$ Percentage of morphologically abnormal spermatozoa of all boars directly after thawing

\begin{tabular}{cccc}
\hline$(\%)$ & $\begin{array}{c}\text { Short } \\
\overline{\mathrm{X}} \pm \text { SD }\end{array}$ & $\begin{array}{c}\text { Medium } \\
\overline{\mathrm{X}} \pm \text { SD }\end{array}$ & $\begin{array}{c}\text { Long } \\
\overline{\mathrm{X}} \pm \text { SD }\end{array}$ \\
\hline \hline $\begin{array}{c}\text { normal apical ridge } \\
(\mathrm{NAR})\end{array}$ & $29.6 \pm 8.1$ & $30.1 \pm 8.3$ & $27.5 \pm 7.9$ \\
\hline dissolving acrosomes & $29.3 \pm 5.9$ & $35.0 \pm 8.6$ & $33.6 \pm 6.2$ \\
\hline lost acrosomes & $41.1 \pm 8.6$ & $34.9 \pm 8.3$ & $38.9 \pm 7.9$ \\
\hline other abnormalities & $1.6 \pm 1.0$ & $1.6 \pm 0.7$ & $1.4 \pm 0.7$ \\
\hline gross morphology & $71.9 \pm 8.5$ & $71.5 \pm 8.2$ & $73.9 \pm 8.1$ \\
\hline not significantly different & & &
\end{tabular}

The acrosome reaction and membrane integrity of the frozen/thawed spermatozoa was flowcytometrically analyzed applying a triple staining method with SYTO17/FITC-PNA/PI. The sperm samples were evaluated at $0 \mathrm{~h}$ and $2 \mathrm{~h}$ after thawing. Table 23-26 show the results of the evaluation for each boar.

There was no significant difference for boar A between freezing treatments neither in the percentage of spermatozoa with intact membranes nor with acrosome reaction . 
Table 23: $\quad$ Flow cytometrical evaluation of Boar A sperm membrane integrity and acrosome reaction of frozen/thawed spermatozoa applying SYTO-17/FITC-PNA/PI $0 \mathrm{~h}$ and $2 \mathrm{~h}$ after thawing

\begin{tabular}{|c|c|c|c|c|}
\hline$(\%)$ & $\begin{array}{l}\text { hours } \\
\text { after } \\
\text { thawing }\end{array}$ & $\begin{array}{l}\text { Short } \\
\bar{X} \pm \text { SD }\end{array}$ & $\begin{array}{c}\text { Medium } \\
\bar{X} \pm S D\end{array}$ & $\begin{array}{l}\text { Long } \\
\bar{X} \pm S D\end{array}$ \\
\hline \multirow{2}{*}{$\begin{array}{l}\text { vital spermatozoa; } \\
\text { intact acrosome }\end{array}$} & $\mathrm{Oh}$ & $45.7 \pm 5.8$ & $40.9 \pm 12.5$ & $51.4 \pm 6.5$ \\
\hline & $2 \mathrm{~h}$ & $40.5 \pm 5.6$ & $37.2 \pm 8.6$ & $43.0 \pm 6.5$ \\
\hline \multirow{2}{*}{$\begin{array}{l}\text { vital spermatozoa; } \\
\text { acrosome reacted }\end{array}$} & $0 \mathrm{~h}$ & $0.9 \pm 0.3$ & $0.9 \pm 0.5$ & $0.8 \pm 0.4$ \\
\hline & $2 \mathrm{~h}$ & $1.1 \pm 0.3$ & $1.3 \pm 0.3$ & $1.0 \pm 0.2$ \\
\hline \multirow{2}{*}{$\begin{array}{c}\text { membrane } \\
\text { damaged sperm; } \\
\text { acrosome intact }\end{array}$} & $0 \mathrm{~h}$ & $36.9 \pm 4.7$ & $41.6 \pm 9.0$ & $32.9 \pm 5.6$ \\
\hline & $2 \mathrm{~h}$ & $38.1 \pm 3.7$ & $41.6 \pm 7.6$ & $37.9 \pm 4.9$ \\
\hline \multirow{2}{*}{$\begin{array}{c}\text { membrane } \\
\text { damaged sperm; } \\
\text { acrosome reacted }\end{array}$} & $0 \mathrm{~h}$ & $16.5 \pm 2.9$ & $16.6 \pm 4.6$ & $15.0 \pm 2.0$ \\
\hline & $2 \mathrm{~h}$ & $20.4 \pm 4.4$ & $19.9 \pm 2.1$ & $18.1 \pm 2.7$ \\
\hline
\end{tabular}


The percentage of viable, acrosome reacted spermatozoa and the percentage of membrane damaged and acrosome reacted spermatozoa of boar B was significantly lower in the sample frozen following the medium timed protocol than following the short and long protocol (Table 24).

Table 24: $\quad$ Flow cytometrical evaluation of Boar B sperm membrane integrity and acrosome reaction of frozen/thawed spermatozoa applying SYTO-17/FITC-PNA/PI 0h and $2 \mathrm{~h}$ after thawing

\begin{tabular}{|c|c|c|c|c|}
\hline$(\%)$ & $\begin{array}{c}\text { hours } \\
\text { after } \\
\text { thawing }\end{array}$ & $\begin{array}{l}\text { Short } \\
\mathrm{X} \pm \mathrm{SD}\end{array}$ & $\begin{array}{c}\text { Medium } \\
\text { X } \pm \text { SD }\end{array}$ & $\begin{array}{l}\text { Long } \\
\mathrm{X} \pm \mathrm{SD}\end{array}$ \\
\hline \multirow{2}{*}{$\begin{array}{c}\text { viable } \\
\text { spermatozoa; intact } \\
\text { acrosome }\end{array}$} & $0 \mathrm{~h}$ & $49.5 \pm 7.5$ & $56.2 \pm 5.8$ & $49.0 \pm 11.59$ \\
\hline & $2 \mathrm{~h}$ & $47.7 \pm 7.6$ & $47.0 \pm 4.2$ & $44.5 \pm 4.8$ \\
\hline \multirow{2}{*}{$\begin{array}{c}\text { viable } \\
\text { spermatozoa; } \\
\text { acrosome reacted }\end{array}$} & $\mathrm{Oh}$ & $2.2 \pm 0.7^{\mathrm{aA}}$ & $1.2 \pm 0.3^{b}$ & $4.5 \pm 7.1^{b}$ \\
\hline & $2 \mathrm{~h}$ & $2.2 \pm 1.0^{\mathrm{B}}$ & $1.5 \pm 0.3$ & $1.3 \pm 0.4$ \\
\hline \multirow{2}{*}{$\begin{array}{c}\text { membrane } \\
\text { damaged } \\
\text { spermatozoa; }\end{array}$} & Oh & $31.6 \pm 9.9$ & $31.9 \pm 4.6$ & $31.1 \pm 4.9$ \\
\hline & $2 \mathrm{~h}$ & $29.8 \pm 9.3$ & $35.1 \pm 4.0$ & $38.2 \pm 4.4$ \\
\hline \multirow{2}{*}{$\begin{array}{c}\text { membrane } \\
\text { damaged } \\
\text { spermatozoa; }\end{array}$} & Oh & $16.6 \pm 3.4^{\mathrm{aA}}$ & $10.8 \pm 2.4^{\mathrm{bA}}$ & $15.4 \pm 8.08^{\mathrm{ac}}$ \\
\hline & $2 \mathrm{~h}$ & $20.3 \pm 6.8$ & $16.5 \pm 3.6^{\mathrm{B}}$ & $16.0 \pm 2.6$ \\
\hline
\end{tabular}


For boar C no significant differences between the three freezing protocols were seen. However, the percentage of viable, acrosome reacted spermatozoa and the percentage of membrane damaged and acrosome reacted spermatozoa was significantly higher $(p \leq 0.05)$ after two hours of incubation of the sample frozen in the short freezing curve.

Table 25: $\quad$ Flow cytometrical evaluation of Boar $\mathrm{C}$ sperm membrane integrity and acrosome reaction of frozen/thawed spermatozoa applying SYTO-17/FITC-PNA/PI $0 \mathrm{~h}$ and $2 \mathrm{~h}$ after thawing

\begin{tabular}{|c|c|c|c|c|}
\hline$(\%)$ & $\begin{array}{l}\text { hours } \\
\text { after } \\
\text { thawing }\end{array}$ & $\begin{array}{l}\text { Short } \\
\bar{X} \pm \text { SD }\end{array}$ & $\begin{array}{c}\text { Medium } \\
\quad \bar{X} \pm \text { SD }\end{array}$ & $\begin{array}{l}\text { Long } \\
\bar{X} \pm S D\end{array}$ \\
\hline \multirow{2}{*}{$\begin{array}{c}\text { viable } \\
\text { spermatozoa; intact } \\
\text { acrosome }\end{array}$} & $0 \mathrm{~h}$ & $61.8 \pm 7.5$ & $63.5 \pm 6.5$ & $51.07 \pm 19.5$ \\
\hline & $2 \mathrm{~h}$ & $57.4 \pm 3.4$ & $54.3 \pm 5.5$ & $55.7 \pm 6.0$ \\
\hline \multirow{2}{*}{$\begin{array}{c}\text { viable } \\
\text { spermatozoa; } \\
\text { acrosome reacted }\end{array}$} & $0 \mathrm{~h}$ & $0.6 \pm 0.5^{\mathrm{A}}$ & $0.7 \pm 0.2$ & $1.0 \pm 0.5$ \\
\hline & $2 \mathrm{~h}$ & $1.7 \pm 0.6^{\mathrm{B}}$ & $1.1 \pm 0.2$ & $1.1 \pm 0.2$ \\
\hline \multirow{2}{*}{$\begin{array}{c}\text { membrane } \\
\text { damaged } \\
\text { spermatozoa; }\end{array}$} & $0 \mathrm{~h}$ & $29.8 \pm 8.5$ & $26.4 \pm 4.8$ & $35.8 \pm 16.7$ \\
\hline & $2 \mathrm{~h}$ & $25.9 \pm 5.8$ & $31.5 \pm 3.7$ & $28.7 \pm 5.9$ \\
\hline \multirow{2}{*}{$\begin{array}{c}\text { membrane } \\
\text { damaged } \\
\text { spermatozoa; }\end{array}$} & $\mathrm{Oh}$ & $7.8 \pm 4.8^{\mathrm{A}}$ & $9.3 \pm 2.1$ & $12.3 \pm 4.2$ \\
\hline & $2 \mathrm{~h}$ & $15.0 \pm 2.5^{\mathrm{B}}$ & $13.1 \pm 2.5$ & $15.5 \pm 2.0$ \\
\hline
\end{tabular}


For boar D there were no significant differences between the three groups but a part of the values differed significantly after two hours of incubation as presented in Table 26.

Table 26: $\quad$ Flow cytometrical evaluation of Boar D sperm membrane integrity and acrosome reaction of frozen/thawed spermatozoa applying SYTO-17/FITC-PNA/PI $0 \mathrm{~h}$ and $2 \mathrm{~h}$ after thawing

\begin{tabular}{|c|c|c|c|c|}
\hline$(\%)$ & $\begin{array}{c}\text { hours } \\
\text { after } \\
\text { thawing }\end{array}$ & $\begin{array}{l}\text { Short } \\
\bar{X} \pm \text { SD }\end{array}$ & $\begin{array}{c}\text { Medium } \\
\bar{X} \pm S D\end{array}$ & $\begin{array}{l}\text { Long } \\
\bar{X} \pm \mathrm{SD}\end{array}$ \\
\hline \multirow{2}{*}{$\begin{array}{c}\text { viable } \\
\text { spermatozoa; intact } \\
\text { acrosome }\end{array}$} & $0 \mathrm{~h}$ & $61.4 \pm 4.7$ & $58.95 \pm 3.76^{\mathrm{A}}$ & $55.3 \pm 11.1$ \\
\hline & $2 \mathrm{~h}$ & $51.9 \pm 3.2$ & $45.4 \pm 3.9^{\mathrm{B}}$ & $48.8 \pm 8.9$ \\
\hline \multirow{2}{*}{$\begin{array}{c}\text { viable } \\
\text { spermatozoa; } \\
\text { acrosome reacted }\end{array}$} & $\mathrm{Oh}$ & $1.3 \pm 0.7^{\mathrm{A}}$ & $0.7 \pm 0.2^{\mathrm{A}}$ & $0.7 \pm 0.6$ \\
\hline & $2 \mathrm{~h}$ & $2.4 \pm 1.1^{\mathrm{B}}$ & $1.6 \pm 0.2^{\mathrm{B}}$ & $1.2 \pm 0.3$ \\
\hline \multirow{2}{*}{$\begin{array}{l}\text { membrane } \\
\text { damaged } \\
\text { spermatozoa; }\end{array}$} & $0 \mathrm{~h}$ & $22.4 \pm 6.4$ & $29.0 \pm 2.4$ & $31.5 \pm 8.4$ \\
\hline & $2 \mathrm{~h}$ & $24.1 \pm 5.5$ & $33.1 \pm 3.0$ & $33.4 \pm 8.5$ \\
\hline \multirow{2}{*}{$\begin{array}{l}\text { membrane } \\
\text { damaged } \\
\text { spermatozoa; }\end{array}$} & $\mathrm{Oh}$ & $15.0 \pm 2.2^{\mathrm{A}}$ & $11.5 \pm 2.8^{\mathrm{A}}$ & $12.5 \pm 3.3$ \\
\hline & $2 \mathrm{~h}$ & $21.6 \pm 3.1^{\mathrm{B}}$ & $19.4 \pm 2.2^{\mathrm{B}}$ & $16.7 \pm 3.3$ \\
\hline
\end{tabular}


For the mean of all boars there were no significant differences between the treatment groups, whereas significant differences could be detected in some cases after two hours of incubation (see Table 27).

Table 27: $\quad$ Flow cytometrical evaluation of sperm membrane integrity and acrosome reaction of frozen/thawed spermatozoa applying SYTO17/FITC-PNA/PI $0 \mathrm{~h}$ and $2 \mathrm{~h}$ after thawing for all boars

\begin{tabular}{|c|c|c|c|c|}
\hline$(\%)$ & $\begin{array}{c}\text { hours } \\
\text { after } \\
\text { thawing }\end{array}$ & $\begin{array}{l}\text { Short } \\
\bar{X} \pm \text { SD }\end{array}$ & $\begin{array}{c}\text { Medium } \\
\text { X } \pm \text { SD }\end{array}$ & $\begin{array}{l}\text { Long } \\
\bar{X} \pm \text { SD }\end{array}$ \\
\hline \multirow{2}{*}{$\begin{array}{c}\text { viable } \\
\text { spermatozoa; intact } \\
\text { acrosome }\end{array}$} & $0 \mathrm{~h}$ & $54.6 \pm 9.5^{\mathrm{A}}$ & $54.9 \pm 11.3^{\mathrm{A}}$ & $51.7 \pm 12.4$ \\
\hline & $2 \mathrm{~h}$ & $49,4 \pm 8,0^{\mathrm{B}}$ & $46,1 \pm 8,2^{\mathrm{B}}$ & $48,0 \pm 8,0$ \\
\hline \multirow{2}{*}{$\begin{array}{c}\text { viable } \\
\text { spermatozoa; } \\
\text { acrosome reacted }\end{array}$} & $0 \mathrm{~h}$ & $1.3 \pm 0.8^{\mathrm{A}}$ & $0,9 \pm 0,4^{\mathrm{A}}$ & $1,7 \pm 3,7$ \\
\hline & $2 \mathrm{~h}$ & $1,8 \pm 0,9^{\mathrm{B}}$ & $1,4 \pm 0,3^{\mathrm{B}}$ & $1,2 \pm 0,3$ \\
\hline \multirow{2}{*}{$\begin{array}{c}\text { membrane } \\
\text { damaged } \\
\text { spermatozoa; }\end{array}$} & $0 \mathrm{~h}$ & $30,1 \pm 8,9$ & $32,2 \pm 7,9^{\mathrm{A}}$ & $32,8 \pm 9,2$ \\
\hline & $2 \mathrm{~h}$ & $29,5 \pm 8,1$ & $35,3 \pm 6,0^{\mathrm{B}}$ & $34,5 \pm 6,9$ \\
\hline \multirow{2}{*}{$\begin{array}{c}\text { membrane } \\
\text { damaged } \\
\text { spermatozoa; }\end{array}$} & $\mathrm{Oh}$ & $14,0 \pm 4,9^{\mathrm{A}}$ & $12,0 \pm 4,0^{\mathrm{A}}$ & $13,8 \pm 4,8^{\mathrm{A}}$ \\
\hline & $2 \mathrm{~h}$ & $19,3 \pm 5,0^{\mathrm{B}}$ & $17,2 \pm 3,7^{\mathrm{B}}$ & $16,3 \pm 2,8^{\mathrm{B}}$ \\
\hline
\end{tabular}




\subsection{Discussion}

Porcine production worldwide would benefit from high fertile frozen/thawed semen usable for artificial insemination as semen could then easily be exchanged among animal breeding companies. Furthermore, gene banks for preservation of high value genetics would be possible. Up until now, artificial insemination with frozen/thawed boar semen has not reached the same fertility rates as insemination with fresh or cooled semen.

The aim of the present study was to use two approaches to improve the quality of frozen thawed boar semen.

The first study showed that the addition of antioxidants to cooling and freezing media can improve the motility after thawing of boar spermatozoa (Table 8). The presence of Catalase, Na-Pyruvate and Mercaptoethanol in cooling and freezing media significantly improved the motility after thawing as compared to control semen without additives. Addition of the vitamin E analogue Trolox did not cause a significant increase in motility. Other reports showed ambivalent results after addition of antioxidants (Askari et al. 1994a, Maxwell and Stojanov 1996, Upreti et al. 1997, Pena et al. 2004b, 2003b, Ball et al. 2001) as the observed effects of antioxidants depended on the kind of substance used and the dose applied. However, it is generally accepted that cryo-preservation induces the formation of reactive oxygen species (ROS) (Watson 2000). Oxygen radicals are known to cause a decrease in motility, induction of capacitation and damage of membrane systems by lipid peroxidation (De Lamirande and Gagnon 1992b, Ichikawa et al. 1999, Oehninger et al. 1995). This is due to the high content of unsaturated fatty acids, which are prone to ROS induced damage (Cerolini et al. 2001). The present results of a supportive action of antioxidants agree with other reports employing antioxidants during the freezing process (Pena et al. 2004b, Cerolini et al. 2001). The effect of the AO-Mix confirms also similar reports on bull semen preservation where Sexcess ${ }^{\circledR}$ has been used for the first time with sex-sorted frozen spermatozoa (Klinc 2005). But the results shown herein did not indicate any improvement to protect the normal apical ridges (NAR) nor the percentage of membrane intact spermatozoa in general. This is contrary to the studies with antioxidants in bull semen (Klinc 2005) where they improved both quality criteria. Pena et al. (2003b) has found that Trolox caused, 
beside its beneficial effect on motility, a higher mitochondrial membrane potential in boar spermatozoa. Cummins et al. (1994) indicated that mitochondria are likely to be the most sensitive part of spermatozoa towards freezing and thawing. It is possible that a mixture of Pyruvate, Catalase and Mercaptoethanol protects the energy metabolism in frozen spermatozoa and improves post-thaw sperm motility. However, they do not sufficiently protect membrane integrity due to the high content of polyunsaturated fatty acids in porcine spermatozoa.

In the second study only little differences in sperm quality could be demonstrated after thawing of boar sperm when using different freezing protocols for individual boars. Only one boar showed significantly better motility after freezing spermatozoa in a prolonged freezing protocol. The other three animals did not show any significant preferences for any protocol. A similar result has been found for acrosome and membrane integrity for all boars.

Spermatozoa are exposed to physical and chemical stress during the process of cooling and freezing, caused by ice formation and changing osmotic conditions during cooling and freezing. Sperm survival after freezing and thawing seems to depend on basic properties of the sperm plasma membrane like biochemical composition, thermal behaviour, osmotic resistance and physical stresses during sperm processing (Hammerstedt et al. 1990, De Leeuw et al. 1991). Sperm recovery is altered by cooling and freezing rates (Fiser and Fairfull 1990, Bwanga et al. 1991a). However, there are complex interactions between cooling rate, glycerol concentration and warming rates causing a different outcome in sperm quality after thawing (Fiser et al. 1991, Fiser et al. 1993). Variation in individual males can overshadow these factors. These factors can be minimized by selecting animals on the basis of cryo-resistance of their semen samples (Almlid et al. 1989b, Berger and Fischerleitner 1992). This could explain the lack of differences between the individual freezing protocols for the four boars used in this experiment. Medrano (1998) supported the view that considerable individual variation between boars exist. In their work post thawing motility varied between 1 and $38 \%$ and the plasma membrane integrity varied between 4 and 36\%. The two parameter were not correlated. Additionally, Holt et al. (2005) showed that post-thaw sperm survival for any individual boar showed little change in response to manipulation of cooling rates. Additionally, while inter-ejaculate variance in post-thaw sperm survival was 
detected, it was significantly outweighed by the inter-boar variance. These findings agree with those of Roca et al. (2006a), where $70 \%$ of total variability in cryosurvival of boar semen could be explained by boar effects. Thus, pre-selection of boars for freezeability is a reliable way of assuring a higher post thaw semen quality. From these findings it can be concluded that antioxidants added to boar semen freezing extender significantly improve the post-thaw sperm motility in particular. Different rates for freezing spermatozoa of individual boars may have only limited effects on post-thaw semen quality if the boars have been previously selected for cryo-resistance. 


\section{CHAPTER 2: Improvement of sex-sorted fresh and frozen-thawed boar spermatozoa and their subsequent insemination efficiency after supplementation of the extender with antioxidants}

\subsection{Introduction}

Gender pre-determination in mammalian offspring by means of flow cytometrical sperm sorting was established first in rabbit spermatozoa (Johnson et al. 1989) and two years later in swine (Johnson 1991). Until now, sperm sexing technology has not been implemented in swine production, although the increased use of AI in pigs demands to alter sex ratio, particularly with genetic companies seeking to produce large numbers of seed stock gilts in multiplier herds. The reason for this is the still limited sperm output even with fast high speed flow cytometers that allow to sort sperm populations of high purity at around 15 million spermatozoa per sex and hour (Johnson et al. 2005b). Sex sorted fresh spermatozoa have been used in sows with non-surgical deep intrauterine insemination (DUI) (Martinez et al. 2001, Rath et al. 2003a, Grossfeld et al. 2005). However, due to the limited fertilizing ability of sex sorted fresh boar spermatozoa the usage requires to have potential sows in close vicinity to the laboratory and to inseminate them shortly before ovulation. These limitation can be overcome if sex sorted spermatozoa could be stored for a longer period in either fresh or frozen state. The long-time storage of sex-sorted semen would furthermore ease the production of gender pre-selected piglets even in herds far away from the sorting laboratory. Until now no piglets have been produced after non-surgical AI with sex-sorted frozen/thawed spermatozoa. In opposite, in cattle a recently new developed post sorting technology (Sexcess ${ }^{\circledR}$ ) has significantly improved the fertility of sex sorted frozen spermatozoa (Klinc 2005). Related to this technique, semen additives have been tested in boar semen and improved the post-thaw quality of non-sorted frozen/thawed boar semen significantly (see Chapter I).

In this study, three different trials tested the effect of antioxidants on the quality of liquid stored semen as well as frozen sex-sorted spermatozoa. Additionally, it was evaluated whether piglets can be produced after surgical insemination with sorted frozen/thawed spermatozoa. 


\subsection{Material and Methods}

\subsubsection{Experiment 1: Improvement of sex sorted fresh boar spermatozoa using Androhep ${ }^{\mathrm{TM}}$ supplemented with different antioxidants}

\subsubsection{Semen processing}

Ejaculates were collected from four boars of the AI-Centre Mariensee using the gloved hand method. Fifty millilitre of the sperm-rich fraction were collected into collection bags (Minitüb, Tiefenbach, Germany) fixed in a thermos receptacle. The Bulbourethral-gland secretion was separated by a filter included in the collection bag. Directly after collection semen was divided into two parts. One part was diluted with pre-warmed $\left(38^{\circ} \mathrm{C}\right)$ Androhep ${ }^{\mathrm{TM}}$ semen extender (Minitüb, Tiefenbach, Germany) (1:1, v/v) containing $24.6 \mathrm{IU} / \mathrm{ml}$ Catalase, 2 mMol Na-Pyruvate and $106 \mu \mathrm{Mol}$ Mercaptoethanol (all from Sigma, St.Louis, MO, USA) per $\mathrm{ml}$ resulting in a final concentration of $12.3 \mathrm{IU} / \mathrm{ml}$ Catalase, $1 \mathrm{mMol} \mathrm{Na-Pyruvate}$ and 53 $\mu \mathrm{Mol}$ Mercaptoethanol per $\mathrm{ml}$ in the diluted semen. The other part of the ejaculate was diluted in the same way, but without additives. Semen was then transported in an isolated container to the laboratory. Spermatozoa were evaluated for motility, concentration and morphology according to the methods described by Krause (1966). Sperm motility was evaluated under a phase contrast microscope (Olympus BX 60, Olympus) supplemented with a heating stage $\left(38^{\circ} \mathrm{C}\right)$ at $100 \mathrm{x}$ magnification. The concentration of the semen was determined in a ThomaCounting-chamber new (Herenz Medizinalbedarf, Hamburg, Germany). Additionally an aliquot of $50 \mu 1$ of semen was fixed in $500 \mu 1$ of Hancock-solution and the morphological status was examined at $1000 \mathrm{x}$ magnification under oil immersion. At least 200 spermatozoa were counted.

\subsubsection{Semen processing for flow cytometrical sorting}

Sperm samples were diluted with Androhep ${ }^{\mathrm{TM}}$ to $100 \times 10^{6}$ per $\mathrm{ml}$. For flow cytometrical sorting 7.5-10 $\mu 1$ Hoechst 33342 dye (Sigma, St.Louis, MO, USA) from a 5mg/ml stocksolution were added. Samples were incubated for 75 minutes at $38^{\circ} \mathrm{C}$. Thereafter, $1 \mu 1$ of food dye (FD\&C \#40, Warner Jenkins Company Inc., St. Louis, MO, USA) was added from a 25 $\mathrm{mg} / \mathrm{ml}$ stock-solution to gate out membrane-damaged spermatozoa in the flow cytometer. Until sorting the samples were stored at room-temperature in the dark and were filtered in a nylon-filter with a pore diameter of $51 \mu \mathrm{m}$ (Reichelt Chemietechnik, Heidelberg) shortly 
before sorting. Flow cytometrical sorting was conducted according to the method developed by Johnson and Welch (1999) with a "High speed cell Sorter" (MoFlo; DakoCytomation, Fort Collins, CO, USA). The flow cytometer was equipped with a 5W Argon-laser with an optical power of $200 \mathrm{~mW}$. The wave length of the laser was 351 to $364 \mathrm{~nm}$. Dulbecco's Phosphate Buffered Saline (DPBS) served as sheath fluid. The sheath fluid contained $12.3 \mathrm{IU} / \mathrm{ml}$ Catalase, $1 \mathrm{mMol}$ Na-Pyruvate and $53 \mu \mathrm{Mol}$ Mercaptoethanol. The flow cytometer operated with a pressure of 3.9 bar at a speed of 27,000 events per second. The sort-rate varied from 2,700 to 3,000 spermatozoa per second. Sorted samples were collected in $10 \mathrm{ml}$ centrifuge tubes (Sarstedt, Nümbrecht), containing $0.5 \mathrm{ml}$ of a $2 \%$ TEST egg yolk-solution supplemented with $10 \%$ seminal plasma. About $8 \times 10^{6}$ spermatozoa were sorted per collection tube and were then centrifuged for $20 \mathrm{~min}$. at $850 \mathrm{x}$ g. The supernatant was discharged and the sperm pellet was re-suspended with Androhep ${ }^{\mathrm{TM}}$ containing $12.3 \mathrm{IU} / \mathrm{ml}$ Catalase, $1 \mathrm{mMol} \mathrm{Na}-$ Pyruvate and $53 \mu \mathrm{Mol}$ Mercaptoethanol. Sorting purity was reanalysed using the Gauss7 program for curve fitting distribution (Johnson 1991).

\subsubsection{Experimental design}

\section{Unsorted semen}

Aliquots of $5 \mathrm{ml}$ diluted semen from both groups with and without antioxidant supplementation were filled in $10 \mathrm{ml}$ centrifuge tubes (Sarstedt, Nümbrecht) and stored at $15^{\circ} \mathrm{C}$. After 0,24 , and $120 \mathrm{~h}$ of storage, an aliquot of $500 \mu \mathrm{l}$ was taken and placed into an Eppendorf-cup on a heated aluminium-block $\left(38^{\circ} \mathrm{C}\right)$. The motility was recorded after $15 \mathrm{~min}$ and $2 \mathrm{~h}$. Additionally after $120 \mathrm{~h}$ of storage at $15^{\circ} \mathrm{C}$ the morphological status of the samples was recorded.

\section{Sex sorted semen}

After sorting and subsequent centrifugation of collection tubes, supernatant was removed and sex-sorted samples were divided into two groups and re-suspended with $80 \mu 1$ of Androhep ${ }^{\mathrm{TM}}$ containing $12.3 \mathrm{IU} / \mathrm{ml}$ Catalase, $1 \mathrm{mMol}$ Na-Pyruvate and $53 \mu \mathrm{Mol}$ Mercaptoethanol or no additives. The samples were subsequently stored at $15^{\circ} \mathrm{C}$. After 0,24 and $120 \mathrm{~h}$ of storage an aliquot of $20 \mu \mathrm{l}$ was taken from the stored samples and was warmed in an Eppendorf-cup at $38^{\circ} \mathrm{C}$. The motility was recorded after $15 \mathrm{~min}$ and 2 hours of incubation. Additionally, the morphological status of spermatozoa stored at $15^{\circ} \mathrm{C}$ was recorded after $120 \mathrm{~h}$ of storage. 


\subsubsection{Experiment 2: Improvement of sex sorted frozen boar spermatozoa using cooling and freezing media supplemented with different antioxidants}

\subsubsection{Semen processing}

The semen was obtained and processed as described in experiment 1.

\subsubsection{Flow cytometrical analysis of acrosome reaction and membrane integrity of fresh spermatozoa}

The degree of acrosome reaction and membrane integrity of fresh spermatozoa was flow cytometrically analyzed applying a triple staining method with SYTO-17/FITC-PNA/PI (Garner et al. 1999, Krienke 2003). At least 10,000 spermatozoa were analyzed per sample. For staining, semen samples were diluted to a final concentration of $5 \times 10^{6}$ spermatozoa $/ \mathrm{ml}$ with Androhep ${ }^{\mathrm{TM}}$. Then samples were stained with SYTO-17 ${ }^{\mathrm{TM}}$ (Molecular Probes, Invitrogen, Karlsruhe, Germany), FITC-PNA and Propidium Iodide 95-98\% (both SigmaAldrich Chemicals, St. Louis, USA). Five hundred micro litre of diluted semen were stained with $2 \mu 1$ SYTO-17TM $(0,5 \mathrm{mM}), 4 \mu 1$ PI $(2,4 \mathrm{mM})$ and $5 \mu 1$ FITC-PNA (100 $\mu 1 / \mathrm{ml}$ DPBS). The samples were mixed and incubated for $15 \mathrm{~min}$ at $38^{\circ} \mathrm{C}$ in an incubator in the dark. Labelled samples were analyzed with a FACScan ${ }^{\mathrm{TM}}$ flow cytometer (Becton Dickinson) equipped with an air-cooled Argon-Ion-Laser with a wave length of $488 \mathrm{~nm}$ and $15 \mathrm{~mW}$ laser power. For the measurements filters were used at 530/30 nm (FL-1) for green fluorescence and at 650LP nm (FL-3) for red fluorescence. Data-acquisition was performed with a Power Mac G4-Computer (Apple Inc.) and the Cellquest ${ }^{\mathrm{TM}}$ Software (Becton Dickinson). For data analysis of samples uniform settings were used. During evaluation the sperm heads were divided into four groups according to their plasma membrane and acrosomal integrity: Sperm with intact membrane and intact acrosome (orange staining, SYTO-17+/PNA-/PI-), membrane damaged sperm with intact or complete lost acrosome (red staining, SYTO-17-/PNA-/PI+), membrane damaged and acrosome reacted sperm (red and green staining, SYTO-17-/PNA+/PI+) and membrane intact and acrosome reacted sperm (orange and green staining, SYTO-17+/PNA+/PI-). The delimitation of the sperm groups was done subjectively with the WinMDI-Software 2.8 (Trotter 1998). 


\subsubsection{Semen processing of flow cytometrical sex sorting}

Flow cytometrical sorting was performed as described in experiment 1.

\subsubsection{Experimental design}

Sperm cryo-preservation was performed according to a modified Westendorf-Protocol (Westendorf et al. 1975).

\subsection{Unsorted semen}

Sperm samples were divided into two groups and were diluted with Androhep ${ }^{\mathrm{TM}}$ to a concentration of either $40 \times 10^{6}$ or $80 \times 10^{6}$ spermatozoa per ml. Four millilitres of diluted semen of each concentration were filled in $10 \mathrm{ml}$ centrifugation tubes (Sarstedt, Nümbrecht) and cooled in a water coated tube to $15^{\circ} \mathrm{C}$ over a period of one hour. The samples were then centrifuged in a cooling centrifuge (Minifuge 2, Heraeus-Christ, Osterode, Germany) at $15^{\circ} \mathrm{C}$ for $10 \mathrm{~min}$ at $800 \mathrm{x} \mathrm{g}$. After centrifugation the supernatant was discarded. Then, the sperm pellets were slowly resuspended with $4 \mathrm{ml}$ of cooling extender $(20 \%$ egg yolk, $80 \%$ Lactosesolution, v/v) containing either the low (12.3 IU/ml Catalase, $1 \mathrm{mMol}$ Na-Pyruvate and 53 $\mu \mathrm{Mol}$ Mercaptoethanol) or high (24.6 IU/ml Catalase, $2 \mathrm{mMol}$ Na-Pyruvate and $106 \mu \mathrm{Mol}$ Mercaptoethanol) concentration of antioxidants per $\mathrm{ml}$ or no additives. The sperm samples were then cooled in an incubator to $5^{\circ} \mathrm{C}$ over a period of $2 \mathrm{~h}$ and were transferred into a cooling room for further processing. Then $2 \mathrm{ml}$ of freezing extender [ $92.5 \%$ cooling extender, 6\% Glycerol (Sigma, St. Louis, MO, USA) and 1.5\% Equex-STM (Nova Chemicals, Situate, MA, USA), v/v] were slowly added to each sperm sample. The freezing extender contained the same amount of antioxidants as the cooling extender. Semen was filled in $0.25 \mathrm{ml}$ plasticstraws (Minitüb, Tiefenbach, Germany). Each straw contained either 8 or $16 \times 10^{6}$ spermatozoa. Freezing of the samples was performed in a closed Styrofoam box $(30 \mathrm{~cm} \mathrm{x} 40$ $\mathrm{cm} \times 85 \mathrm{~cm}=$ high $\times$ width $\times$ length). Briefly, straws were placed on a metal holder in nitrogen vapour $4 \mathrm{~cm}$ above liquid nitrogen level for 20 minutes. Frozen samples were then plunged into liquid nitrogen and kept in a storage container until analysis.

\subsection{Sex-sorted semen}

After sorting and centrifugation the sperm pellet $(30 \mu 1)$ with sexed spermatozoa was resuspended with either $45 \mu \mathrm{l}$ or $120 \mu \mathrm{l}$ cooling extender $(20 \%$ egg yolk, $80 \%$ Lactose-solution, $\mathrm{v} / \mathrm{v})$ containing either the low $(12.3 \mathrm{IU} / \mathrm{ml}$ Catalase, $1 \mathrm{mMol}$ Na-Pyruvate and $53 \mu \mathrm{Mol}$ Mercaptoethanol) or high $(24.6 \mathrm{IU} / \mathrm{ml}$ Catalase, $2 \mathrm{mMol}$ Na-Pyruvate and $106 \mu \mathrm{Mol}$ 
Mercaptoethanol) concentration of antioxidants per $\mathrm{ml}$ or no additives. The sperm samples were placed in a water coated tube and cooled in a cooling room to $5^{\circ} \mathrm{C}$ over period of $2 \mathrm{~h}$. The minimum storage time in the cooling room was 2 hours, the maximum time 4 hours. After cooling to $5^{\circ} \mathrm{C}$ two of the sperm samples resuspended with $45 \mu 1$ of cooling extender were put together in one tube. Thereafter, $75 \mu 1$ freezing extender [92.5\% cooling extender, 6\% Glycerol (Sigma, St. Louis, MO, USA) and 1.5\% Equex-STM (Nova Chemicals, Situate, MA, USA) , v/v] containing the same amount of antioxidants as the cooling extender were added to all sperm samples and the semen was filled in $0.25 \mathrm{ml}$ plastic-straws (Minitüb, Tiefenbach, Germany). Each straw contained either 8 or $16 \times 10^{6}$ spermatozoa. Freezing of the samples was performed in a closed Styrofoam box as described above.

Table 28 summarizes the treatment groups of experiment 2

Table 28: Treatment groups for cryo-preservation of sex-sorted semen

\begin{tabular}{ccccc}
\hline Treatment & $\begin{array}{c}\text { unsexed } \\
\text { semen }\end{array}$ & $\begin{array}{c}\text { sex-sorted } \\
\text { spermatozoa }\end{array}$ & Antioxidants & $\begin{array}{c}\text { Sperm per } \\
\text { straw } \mathbf{~ 1 0}\end{array}$ \\
\hline \hline Control-1 & $\mathrm{X}$ & & none & 8 \\
\hline Control-2 & $\mathrm{X}$ & & low & 8 \\
\hline Control-3 & $\mathrm{X}$ & $\mathrm{X}$ & high & 8 \\
\hline Control-4 & $\mathrm{X}$ & $\mathrm{X}$ & none & 16 \\
\hline Sexed-1 & & $\mathrm{X}$ & low & 8 \\
\hline Sexed-2 & & $\mathrm{X}$ & high & 8 \\
\hline Sexed-3 & & $\mathrm{X}$ & none & 16 \\
\hline Sexed-4 & & $\mathrm{X}$ & low & 16 \\
\hline Sexed-5 & & $\mathrm{X}$ & high & 16 \\
\hline Sexed-6 & & & &
\end{tabular}

\subsubsection{Analysis of frozen thawed spermatozoa}

Straws were thawed at $38^{\circ} \mathrm{C}$ for $30 \mathrm{sec}$. and were emptied in $1.5 \mathrm{ml}$ Eppendorf cups placed on a heated aluminium-block $\left(38^{\circ} \mathrm{C}\right)$. Androhep ${ }^{\mathrm{TM}}(400 \mu \mathrm{l})$ was added to each Eppendorf cup and sperm samples were kept at $38^{\circ} \mathrm{C}$ until evaluation. The motility of the frozen/thawed semen samples was analyzed $10 \mathrm{~min}, 1 \mathrm{~h}, 2 \mathrm{~h}, 3 \mathrm{~h}$ and $6 \mathrm{~h}$ after thawing under a phase-contrast microscope (Olympus BX 60, Olympus) equipped with a heating plate (Minitüb, Tiefenbach, Germany) at $38^{\circ} \mathrm{C}$. Two drops and at least three fields per drop were analysed in each sample at 100x magnification. 


\subsubsection{Analysis of morphologically abnormal spermatozoa}

For analysis of frozen/thawed spermatozoa an aliquot of $20 \mu 1$ thawed spermatozoa was put in an Eppendorf tube and mixed with $40 \mu 1$ Hancock-Solution. Morphological abnormalities and acrosome integrity were analysed under a phase-contrast microscope (Olympus BX 60, Olympus) at 1000x magnification after fixation. At least 100 spermatozoa were examined in the frozen/thawed samples.

\subsubsection{Flow-cytometrical analysis of acrosome reaction and membrane integrity of frozen/thawed spermatozoa (SYTO-17, FITC-PNA, PI)}

The acrosome reaction and membrane integrity of the frozen/thawed spermatozoa was flow cytometrically analyzed as described above. At least 3000 spermatozoa were analyzed per sample. The debris of the egg yolk extender was gated out according to the method developed by Nagy et al. (2003).

\subsubsection{Experiment 3: Tubal insemination of sex-sorted frozen/thawed boar spermatozoa}

In the third experiment boar semen was collected, sex-sorted and frozen/thawed as described above. Additionally control semen with 2 million spermatozoa per straw containing 12.3 IU/ml Catalase, $1 \mathrm{mMol}$ Na-Pyruvate and $53 \mu \mathrm{Mol}$ Mercaptoethanol per ml was prepared. For tubal insemination 2 million spermatozoa per straw were used.

\subsubsection{Surgical insemination procedure}

Six prepuberal gilts (German Landrace) housed in individual crates were inseminated surgically into the oviduct. Therefore gilts were synchronized with 1500 IU PMSG i.m. and $500 \mathrm{IU}$ hCG administered i.m. 72h later. Surgical insemination into the oviduct was performed $38 \mathrm{~h}$ after hCG treatment short before ovulation. Gilts were anesthetized with $8 \mathrm{ml}$ Stresnil and $25 \mathrm{ml}$ Trapanal. They were prepared for surgery in dorsal recumbence, and the uterine horns and oviducts were exposed by mid-ventral laparotomy. Frozen sex-sorted and control sperm samples were thawed directly before insemination for $12 \mathrm{sec}$ at $50^{\circ} \mathrm{C}$ in a water bath and motility was recorded. Per oviduct the contents of one straw was used for insemination. The straws were connected to a blunt $18 \mathrm{~g}$ needle that was inserted into the tip of the uterine horn, guided towards the utero- tubal junction (UTJ) and semen was released into the oviductal ampoule. The procedure was repeated in the opposite horn, and the genital 
tract was replaced into the abdominal cavity. Surgical closure was performed with Safil C, no. 7 metric (B/BRAUN, Aesculap, Melsungen, Germany).

To evaluate the number of fertilized oocytes the animals were slaughtered 48 hours later, the genital tract was extracted and transported in an isolated container into the laboratory. The oviducts and upper part of the uterus horns were flushed separately with $30 \mathrm{ml}$ pre-warmed $\left(38^{\circ} \mathrm{C}\right)$ Dulbecco's phosphor buffered saline. Collection media were searched for embryos, which were collected and were stained with Hoechst 33342 for cell count and determination of the development status.

\subsubsection{Statistical analysis}

Statistical analyses were performed with SIGMA STAT 2.03 for windows (Jandel Scientific Cooperation, San Ragael, CA, USA). The effect of the group treatment on the quality of the semen was analysed for normal distribution and tested with One-way ANOVA or ANOVA on Ranks and Tukey test. Data are expressed as percentages or means \pm sd. Differences were considered to be significant at $\mathrm{P}<0.05$. 


\subsection{Results}

\subsubsection{Experiment 1: Improvement of sex sorted fresh boar spermatozoa using} Androhep ${ }^{\mathrm{TM}}$ supplemented with different antioxidants

Ten ejaculates from four boars were obtained during the experiment. The estimated motility of the samples after collection and dilution with Androhep ${ }^{\mathrm{TM}}$ was $74.0 \pm 4.36 \%$. The mean concentration of the samples was $280.0 \pm 158.03 \times 10^{6}$ spermatozoa per ml. The mean percentage of morphological abnormal spermatozoa was $24.93 \% \pm 12.67 \%$. The percentage of spermatozoa with normal apical ridges was $98.5 \pm 0.91 \%$. The percentage of spermatozoa with distal plasma droplets was $20.34 \pm 9.45 \%$. The reanalysis of semen revealed $92.5 \%$ average purity for X-chromosome bearing spermatozoa.

\subsubsection{Evaluation of motility after storage and incubation}

Table 29 shows the results of the motility evaluation after 0,24 and $120 \mathrm{~h}$ of storage at $15^{\circ} \mathrm{C}$ and subsequent incubation at $38^{\circ} \mathrm{C}$. The motility decreased during storage at $15^{\circ} \mathrm{C}$ as well as during incubation at $38^{\circ} \mathrm{C}$ in all treatment groups. Sperm motility did not differ between sorted and unsorted spermatozoa except for spermatozoa that were stored for $120 \mathrm{~h}$ at $15^{\circ} \mathrm{C}$ and were evaluated after $15 \mathrm{~min}$ of incubation at $38^{\circ} \mathrm{C}(\mathrm{P} \leq 0.05)$. The addition of antioxidants had no significant effect on sorted spermatozoa.

Table 29: $\quad$ Sperm motility of fresh and sex-sorted samples after 0, 24 and 120 hours of storage at $15^{\circ} \mathrm{C}$ and subsequent incubation at $38^{\circ} \mathrm{C}$ extended in Androhep ${ }^{\mathrm{TM}}$ containing different antioxidants or no additives

\begin{tabular}{|c|c|c|c|c|c|c|}
\hline $\begin{array}{c}\text { \% motile } \\
\text { spermatozoa }\end{array}$ & $\begin{array}{c}\text { Oh storage at } \\
15^{\circ} \mathrm{C}\end{array}$ & & $\begin{array}{c}\text { 24h storage at } \\
15^{\circ} \mathrm{C}\end{array}$ & & $\begin{array}{c}\text { 120h storage } \\
\text { at } 15^{\circ} \mathrm{C}\end{array}$ & \\
\hline & $\begin{array}{c}15 \mathrm{~min} \\
\text { incubation at } \\
38^{\circ} \mathrm{C} \overline{\mathrm{x}} \pm \mathrm{SD}\end{array}$ & $\begin{array}{l}2 \mathrm{~h} \text { incubation } \\
\text { at } 38^{\circ} \mathrm{C} \overline{\mathrm{x}} \pm \mathrm{SD}\end{array}$ & $\begin{array}{c}15 \mathrm{~min} \\
\text { incubation at } \\
38^{\circ} \mathrm{C} \overline{\mathrm{x}} \pm \mathrm{SD}\end{array}$ & $\begin{array}{l}2 \mathrm{~h} \text { incubation } \\
\text { at } 38^{\circ} \mathrm{C} \overline{\mathrm{x}} \pm \mathrm{SD}\end{array}$ & $\begin{array}{c}15 \mathrm{~min} \\
\text { incubation at } \\
38^{\circ} \mathrm{C} \overline{\mathrm{x}} \pm \mathrm{SD}\end{array}$ & $\begin{array}{l}2 \mathrm{~h} \text { incubation } \\
\text { at } 38^{\circ} \mathrm{C} \overline{\mathrm{x}} \pm \mathrm{SD}\end{array}$ \\
\hline $\begin{array}{l}\text { Unsorted, no } \\
\text { additives }\end{array}$ & $70.0 \pm 5.9$ & $65.5 \pm 6.5$ & $64.4 \pm 6.9$ & $55.0 \pm 12.9$ & $59.5 \pm 5.2^{\mathrm{a}}$ & $55.0 \pm 7.1$ \\
\hline $\begin{array}{l}\text { Unsorted, + } \\
\text { antioxidants }\end{array}$ & $71.0 \pm 6.6$ & $66.0 \pm 7.0$ & $64.0 \pm 6.6$ & $59.0 \pm 12.4$ & $60.0 \pm 5.5^{\mathrm{a}}$ & $56.5 \pm 5.0$ \\
\hline $\begin{array}{l}\text { Sex-sorted, no } \\
\text { additives }\end{array}$ & $68.0 \pm 2.5$ & $54.7 \pm 27.0$ & $55.0 \pm 13.5$ & $38.3 \pm 21.3$ & $22.0 \pm 15.8^{b}$ & $18.0 \pm 15.4$ \\
\hline $\begin{array}{l}\text { Sex-sorted }+, \\
\text { antioxidants }\end{array}$ & $68.3 \pm 2.4$ & $60.0 \pm 21.5$ & $61.7 \pm 6.7$ & $39.4 \pm 23.5$ & $28.3 \pm 14.7^{b}$ & $21.7 \pm 19.1$ \\
\hline
\end{tabular}




\subsubsection{Evaluation of sperm morphology after storage and incubation}

The evaluation of the percentage of morphological abnormal spermatozoa showed a significantly higher amount of normal apical ridges (NAR) in the unsorted treatment groups compared to sex-sorted samples. Neither for unsorted nor for sex-sorted spermatozoa the addition of antioxidants improved the percentage of spermatozoa with lost acrosomes, except when comparing unsorted spermatozoa in extender with antioxidants vs. sex-sorted spermatozoa without additives $(\mathrm{P} \leq 0.05)$. The percentage of spermatozoa with dissolving acrosomes was not affected by sorting, although the non-sorted samples had less dissolving acrosomes. However, the difference was only statistically significant when comparing the non-sorted groups with the sex-sorted semen with addition of antioxidants. Table 30 summarizes the results of the morphological analysis.

Table 30: Results of the morphological evaluation of the semen samples after $120 \mathrm{~h}$ of storage at $15^{\circ} \mathrm{C}$

\begin{tabular}{|c|c|c|c|c|}
\hline $\begin{array}{c}\% \text { morphological } \\
\text { abnormal spermatozoa } \\
\text { after } 120 \mathrm{~h} \text { storage at } \\
15^{\circ} \mathrm{C}\end{array}$ & normal apical ridge & $\begin{array}{c}\text { dissolving } \\
\text { acrosome } \\
\overline{\mathrm{x}} \pm \mathrm{SD}\end{array}$ & lost acrosome & other abnormalities \\
\hline Non-sorted, no additives & $87.9 \pm 4.2^{\mathrm{a}}$ & $\overline{5.2 \pm 1.4^{\mathrm{a}}}$ & $6.95 \pm 3.4^{\mathrm{ac}}$ & $23.9 \pm 15.0$ \\
\hline $\begin{array}{l}\text { Non-sorted, } \\
+ \text { antioxidants }\end{array}$ & $90.4 \pm 2.3^{\mathrm{a}}$ & $4.3 \pm 2.0^{\mathrm{a}}$ & $5.4 \pm 3.2^{\mathrm{a}}$ & $22.3 \pm 12.0$ \\
\hline Sex-sorted, no additives & $63.7 \pm 24.3^{b}$ & $11.7 \pm 9.1^{\mathrm{ac}}$ & $24.6 \pm 16.3^{b}$ & $17.3 \pm 19.0$ \\
\hline $\begin{array}{c}\text { Sex-sorted, } \\
+ \text { antioxidants }\end{array}$ & $62.4 \pm 20.6^{\mathrm{b}}$ & $16.8 \pm 8.0^{\mathrm{bc}}$ & $20.8 \pm 15.0^{\mathrm{bc}}$ & $16.1 \pm 22.3$ \\
\hline
\end{tabular}

$\mathrm{a}: \mathrm{b}: \mathrm{c} \mathrm{p} \leq 0.05$ between treatment groups

\subsubsection{Experiment 2: Improvement of sex sorted frozen boar spermatozoa using cooling and freezing media supplemented with different antioxidants}

During the experiment six ejaculates were obtained from three boars. The estimated motility of the samples right after collection and dilution with Androhep ${ }^{\mathrm{TM}}$ was $75.0 \pm 3.16 \%$.

The mean concentration of the fresh samples was $578.3 \pm 147.6 \times 10^{6}$. The mean percentage of morphological abnormal spermatozoa was $15.2 \pm 7.6 \%$. The percentage of spermatozoa with normal apical ridges was $98.8 \pm 0.7 \%$. 


\subsubsection{Evaluation of membrane integrity and acrosome reaction}

Table 31 displays the results of the flow cytometrical evaluation of membrane integrity and acrosome reaction of the fresh semen samples after collection and 1:2 (v:v) dilution with Androhep ${ }^{\mathrm{TM}}$.

Table 31: Results of the flow cytometrical evaluation of membrane integrity and acrosome reaction of fresh spermatozoa applying SYTO-17/FITC-PNA/PI staining

\begin{tabular}{cc}
\hline Parameter & $\begin{array}{c}\text { \% spermatozoa } \\
\overline{\mathrm{X}} \pm \mathrm{SD}\end{array}$ \\
\hline vital spermatozoa; intact acrosome & $83.9 \pm 14.4$ \\
\hline vital spermatozoa; acrosome reacted & $2.5 \pm 1.3$ \\
\hline membrane damaged sperm; acrosome non & $9.5 \pm 11.0$ \\
\hline membrane damaged sperm; acrosome reacted & $4.0 \pm 4.0$ \\
\hline
\end{tabular}

\subsubsection{Evaluation of sperm motility after sorting and freezing}

The motility of the spermatozoa after sex sorting and before cooling to $15^{\circ} \mathrm{C}$ was $65.0 \pm 2.8 \%$. Motility after thawing and subsequent maintenance at $38^{\circ} \mathrm{C}$ (thermo resistance test) was analyzed at $0,1,2,3$ and $6 \mathrm{~h}$.

Immediately after thawing only the samples from group Sexed-1 (sex-sorted, no additives, 40 x $10^{6}$ sperm per ml; see Table 28) showed a significant lower motility than all other groups $(\mathrm{P} \leq 0.05)$. After this, no significant differences in the sperm motility could be detected between the treatment groups. During the thermo resistance test sperm motility significantly decreased during incubation within eight of the ten treatment groups (Table 32), when comparing the percentage of motile spermatozoa $0 \mathrm{~h}$ vs. $1 \mathrm{~h}, 2 \mathrm{~h}, 3 \mathrm{~h}$ and $6 \mathrm{~h}$ after thawing. The treatment groups Sexed-1, Sexed-4 (see Table 28) showed no significant decrase when compared to motility directly after thawing, whereas the treatment-groups Control-4, Sexed-2, $-3,-5,-6$ showed a significant decrease in motility after two and the groups Control-2 and Control-3 showed a significant decrease after three hours when compared with the motility directly after thawing. The Control-1 group showed a significant decrease in motility after $6 \mathrm{~h}$ $(\mathrm{p}<0.05)$. 
Table 32: $\quad$ Percentage of motile spermatozoa after thawing and dilution in AndrohepTM at $0,1,2,3$ and 6 hours after thawing

\begin{tabular}{|c|c|c|c|c|c|}
\hline \multirow{2}{*}{ Treatment } & $0 \mathrm{~h}$ & $1 \mathrm{~h}$ & $2 \mathrm{~h}$ & $3 \mathrm{~h}$ & $6 \mathrm{~h}$ \\
\hline & $\overline{\mathrm{x}} \pm \mathrm{SD}$ & $\overline{\mathrm{X}} \pm \mathrm{SD}$ & $\overline{\mathrm{X}} \pm \mathrm{SD}$ & $\overline{\mathrm{X}} \pm \mathrm{SD}$ & $\overline{\mathrm{X}} \pm \mathrm{SD}$ \\
\hline "Control-1 & $48.3 \pm 17.2^{\mathrm{aA}}$ & $43.3 \pm 11.7^{\mathrm{A}}$ & $25.8 \pm 10.7$ & $15.8 \pm 3.8$ & $2.8 \pm 2.0^{\mathrm{B}}$ \\
\hline Control-2 & $55.0 \pm 9.5^{\mathrm{aA}}$ & $49.2 \pm 8.6$ & $30.0 \pm 13.8$ & $17.5 \pm 11.7^{\mathrm{B}}$ & $3.5 \pm 3.3^{\mathrm{B}}$ \\
\hline Control-3 & $50.8 \pm 19.3^{\mathrm{aA}}$ & $38.2 \pm 18.3^{\mathrm{A}}$ & $14.4 \pm 6.8^{\mathrm{A}}$ & $11.7 \pm 6.8^{\mathrm{B}}$ & $3.7 \pm 2.4^{\mathrm{B}}$ \\
\hline Control-4 & $48.0 \pm 10.4^{\mathrm{aA}}$ & $45.0 \pm 8.7^{\mathrm{A}}$ & $25.0 \pm 10.0^{\mathrm{B}}$ & $15.4 \pm 7.3^{\mathrm{B}}$ & $4.2 \pm 4.8^{\mathrm{B}}$ \\
\hline Sexed-1 & $16.7 \pm 2.6^{b}$ & $13.7 \pm 9.5$ & $10.3 \pm 9.9$ & $6.7 \pm 2.9$ & $1.3 \pm 1.9$ \\
\hline Sexed-2 & $23.0 \pm 9.7^{\mathrm{aA}}$ & $15.0 \pm 6.1$ & $10.0 \pm 5.0^{\mathrm{B}}$ & $10.2 \pm 7.6^{\mathrm{B}}$ & $3.8 \pm 4.3^{\mathrm{B}}$ \\
\hline Sexed-3 & $25.8 \pm 11.6^{\mathrm{aA}}$ & $15.8 \pm 5.8$ & $13.3 \pm 5.2^{\mathrm{B}}$ & $12.5 \pm 14.1^{\mathrm{B}}$ & $4.3 \pm 5.5^{\mathrm{B}}$ \\
\hline Sexed-4 & $25.0 \pm 14.7^{\mathrm{a}}$ & $32.5 \pm 17.6$ & $16.3 \pm 9.5$ & $13.8 \pm 4.8$ & $9.3 \pm 7.4$ \\
\hline Sexed-5 & $38.3 \pm 8.8^{\mathrm{aA}}$ & $30.0 \pm 12.6^{\mathrm{AB}}$ & $14.8 \pm 10.0^{\mathrm{BC}}$ & $15.3 \pm 11.1^{\mathrm{BC}}$ & $4.2 \pm 3.1^{\mathrm{C}}$ \\
\hline Sexed-6 & $32.5 \pm 10.4^{\mathrm{aA}}$ & $36.7 \pm 11.3^{\mathrm{A}}$ & $20.0 \pm 5.5^{\mathrm{B}}$ & $16.7 \pm 9.3^{\mathrm{B}}$ & $4.8 \pm 3.3^{\mathrm{B}}$ \\
\hline
\end{tabular}

$a: b p \leq 0.05$ at same time after thawing between treatment groups

$\mathrm{A}: \mathrm{B}: \mathrm{C} \mathrm{p} \leq 0.05$ at different time-points within one treatment group

The definition of the treatment groups is displayed in Table 28 . 


\subsubsection{Evaluation of sperm morphology after sorting and freezing}

Spermatozoa of the different treatment groups were evaluated directly after thawing. Table 33 shows the results of the morphological evaluation. No significant differences were found between treatment groups.

Table 33: Results of the morphological evaluation of the spermatozoa after freezing and thawing

\begin{tabular}{|c|c|c|c|c|c|}
\hline Treatment & $\begin{array}{c}\% \\
\text { morphologically } \\
\text { intact } \\
\text { spermatozoa }\end{array}$ & $\begin{array}{c}\text { \% Normal } \\
\text { apical } \\
\text { ridge }\end{array}$ & $\begin{array}{c}\% \\
\text { dissolving } \\
\text { acrosome }\end{array}$ & $\begin{array}{c}\% \text { lost } \\
\text { acrosome }\end{array}$ & $\%$ other abnormalities \\
\hline & $\overline{\mathrm{X}} \pm \mathrm{SD}$ & $\overline{\mathrm{X}} \pm \mathrm{SD}$ & $\overline{\mathrm{X}} \pm \mathrm{SD}$ & $\overline{\mathrm{X}} \pm \mathrm{SD}$ & $\overline{\mathrm{X}} \pm \mathrm{SD}$ \\
\hline "Control-1 & $63.33 \pm 11.1$ & $40.0 \pm 11.4$ & $3.8 \pm 4.8$ & $56.2 \pm 9.5$ & $3.3 \pm 0.8$ \\
\hline Control-2 & $62.2 \pm 11.7$ & $41.2 \pm 12.7$ & $6.2 \pm 5.8$ & $53.7 \pm 12.0$ & $3.3 \pm 1.4$ \\
\hline Control-3 & $55.8 \pm 7.1$ & $47.3 \pm 8.7$ & $3.0 \pm 6.0$ & $49.7 \pm 8.3$ & $3.2 \pm 3.1$ \\
\hline Control-4 & $68.8 \pm 11.8$ & $35.2 \pm 10.0$ & $2.8 \pm 2.8$ & $62.0 \pm 7.7$ & $4.0 \pm 2.6$ \\
\hline Sexed-1 & $72.3 \pm 9.9$ & $29.17 \pm 10.9$ & $3.2 \pm 3.2$ & $67.7 \pm 9.9$ & $1.5 \pm 1.9$ \\
\hline Sexed-2 & $63.2 \pm 10.2$ & $39.2 \pm 11.2$ & $2.4 \pm 2.6$ & $58.4 \pm 10.1$ & $3.0 \pm 2.5$ \\
\hline Sexed-3 & $62.8 \pm 15.1$ & $39.5 \pm 18.1$ & $3.8 \pm 3.7$ & $56.7 \pm 16.2$ & $2.3 \pm 3.4$ \\
\hline Sexed-4 & $63.8 \pm 5.1$ & $38.8 \pm 4.3$ & $4.3 \pm 5.1$ & $57.0 \pm 6.2$ & $2.5 \pm 1.0$ \\
\hline Sexed-5 & $65.3 \pm 9.4$ & $36.3 \pm 10.6$ & $4.2 \pm 4.0$ & $59.5 \pm 11.0$ & $1.7 \pm 1.9$ \\
\hline Sexed-6 & $71.8+8.8$ & $30.5 \pm 9.6$ & $3.8 \pm 3.1$ & $65.7 \pm 8.6$ & $2.3 \pm 2.7$ \\
\hline
\end{tabular}




\subsubsection{Evaluation of membrane integrity and acrosome reaction after thawing}

The status of membrane integrity and acrosome reaction were evaluated in the flow cytometer and results were classified in four groups: vital spermatozoa with intact acrosome, vital spermatozoa with reacted acrosome, membrane damaged sperm with non reacted acrosome and membrane damaged sperm with reacted acrosome. Directly after thawing the Control-1 (unsexed, without additives, $40 \times 10^{6}$ sperm per $\mathrm{ml}$ ) spermatozoa showed a significant $(\mathrm{P} \leq 0.05)$ higher portion of viable sperm with intact acrosomes than the Sexed-4 group (sexed, without additives, $80 \times 10^{6}$ sperm per $\mathrm{ml}$ ) as can be seen in Table 34. Further incubation did not reveal differences among treatment groups . However, in all groups the percentage of vital and acrosome intact spermatozoa decreased significantly $(\mathrm{P} \leq 0.05)$ during the incubation for six hours (Table 34). Furthermore, the percentage of membrane damaged and acrosome intact spermatozoa was significantly higher $(\mathrm{P} \leq 0.05)$ after six hours in the groups Control-1, Control-2, Sexed-5 and Sexed-6. The percentage of membrane damaged and acrosome reacted spermatozoa was significantly $(\mathrm{P} \leq 0.05)$ increased after three hours in the Control-1, Sexed-1, Sexed-2, Sexed-3, Sexed-5 and Sexed-6 and after six hours in the Control-2 group (see Table 28 for definition of groups). No link to either sorting, antioxidants addition or concentration nor sperm concentration could be detected. 
Table 34: Results of flow cytometrical evaluation of membrane integrity and acrosome reaction of frozen/thawed spermatozoa applying SYTO-17/FITC-PNA/PI 0h, 3h and 6h after thawing (values are displayed as $\overline{\mathrm{X}} \pm \mathrm{SD}$ )

\begin{tabular}{|c|c|c|c|c|c|c|c|c|c|c|c|c|}
\hline \multirow{3}{*}{$\begin{array}{c}\text { Parameter } \\
\text { h after } \\
\text { thawing }\end{array}$} & \multicolumn{3}{|c|}{ membrane damaged sperm; acrosome } & \multicolumn{3}{|c|}{$\begin{array}{c}\text { vital spermatozoa; intact acrosome } \\
(\%)\end{array}$} & \multicolumn{3}{|c|}{$\begin{array}{l}\text { vital spermatozoa; acrosome reacted } \\
\qquad(\%)\end{array}$} & \multicolumn{3}{|c|}{$\begin{array}{l}\text { membrane damaged sperm; } \\
\text { acrosome intact (\%) }\end{array}$} \\
\hline & Oh & $3 h$ & $6 h$ & Oh & $3 \mathrm{~h}$ & $6 h$ & Oh & $3 h$ & $6 h$ & Oh & $3 \mathrm{~h}$ & $6 h$ \\
\hline & $\overline{\mathrm{x}} \pm \mathrm{SD}$ & $\overline{\mathrm{x}} \pm \mathrm{SD}$ & $\overline{\mathrm{x}} \pm \mathrm{SD}$ & $\overline{\mathrm{x}} \pm \mathrm{SD}$ & $\overline{\mathrm{x}} \pm \mathrm{SD}$ & $\overline{\mathrm{x}} \pm \mathrm{SD}$ & $\overline{\mathrm{x}} \pm \mathrm{SD}$ & $\overline{\mathrm{x}} \pm \mathrm{SD}$ & $\overline{\mathrm{x}} \pm \mathrm{SD}$ & $\overline{\mathrm{x}} \pm \mathrm{SD}$ & $\overline{\mathrm{x}} \pm \mathrm{SD}$ & $\overline{\mathrm{x}} \pm \mathrm{SD}$ \\
\hline Control-1 & $12.8 \pm 3.6^{\mathrm{A}}$ & $21.4 \pm 6.5^{\mathrm{B}}$ & $24.6 \pm 5.7^{\mathrm{B}}$ & $60.6 \pm 5.0^{\mathrm{aA}}$ & $42.9 \pm 1.8^{\mathrm{B}}$ & $35.9 \pm 5.3^{\mathrm{C}}$ & $1.0 \pm 1.3$ & $3.1 \pm 0.8$ & $3.1 \pm 2.2$ & $25.6 \pm 3.6^{\mathrm{A}}$ & $32.6 \pm 5.8$ & $36.5 \pm 9.6^{\mathrm{B}}$ \\
\hline Control-2 & $12.9 \pm 4.2^{\mathrm{A}}$ & $20.0 \pm 8.0$ & $23.8 \pm 8.1^{\mathrm{B}}$ & $58.9 \pm 6.4^{\mathrm{A}}$ & $44.6 \pm 6.2^{\mathrm{BC}}$ & $36.6 \pm 7.9^{\mathrm{C}}$ & $0.8 \pm 1.1^{\mathrm{A}}$ & $3.2 \pm 1.9^{\mathrm{B}}$ & $2.2 \pm 1.2^{\mathrm{AB}}$ & $27.4 \pm 3.3^{\mathrm{A}}$ & $32.1 \pm 5.8$ & $37.4 \pm 6.2^{\mathrm{B}}$ \\
\hline Control-3 & $13.5 \pm 5.8$ & $22.1 \pm 9.2$ & $24.3 \pm 10.9$ & $57.8 \pm 8.3^{\mathrm{A}}$ & $40.7 \pm 6.2^{\mathrm{A}}$ & $35.4 \pm 5.7^{\mathrm{BC}}$ & $1.1 \pm 1.4$ & $2.8 \pm 1.1$ & $2.3 \pm 1.3$ & $27.7 \pm 3.8$ & $34.4 \pm 6.1$ & $38.1 \pm 9.3$ \\
\hline Control-4 & $15.7 \pm 3.6$ & $24.1 \pm 8.5$ & $26.5 \pm 10.8$ & $56.4 \pm 5.5^{\mathrm{A}}$ & $40.2 \pm 4.6^{\mathrm{BC}}$ & $33.0 \pm 5.3^{\mathrm{C}}$ & $1.1 \pm 1.2$ & $2.6 \pm 0.4$ & $1.8 \pm 0.2$ & $26.8 \pm 5.6$ & $33.1 \pm 5.8$ & $38.8 \pm 8.7$ \\
\hline Sexed-1 & $17.4 \pm 1.4^{\mathrm{A}}$ & $30.2 \pm 2.8^{\mathrm{B}}$ & $33.2 \pm 5.8^{\mathrm{B}}$ & $52.9 \pm 5.3^{\mathrm{A}}$ & $33.5 \pm 4.8^{\mathrm{BC}}$ & $26.1 \pm 5.4^{\mathrm{C}}$ & $1.6 \pm 1.4$ & $2.3 \pm 1.7$ & $2.0 \pm 1.5$ & $28.1 \pm 4.687$ & $34.0 \pm 7.8$ & $38.7 \pm 9.7$ \\
\hline Sexed-2 & $15.4 \pm 2.1^{\mathrm{A}}$ & $28.3 \pm 5.9^{\mathrm{B}}$ & $27.8 \pm 10.1^{\mathrm{B}}$ & $53.2 \pm 5.0^{\mathrm{A}}$ & $34.6 \pm 5.0^{\mathrm{B}}$ & $25.9 \pm 4.2^{\mathrm{C}}$ & $1.6 \pm 1.1$ & $2.1 \pm 0.7$ & $1.4 \pm 0.4$ & $29.8 \pm 3.9$ & $35.0 \pm 9.3$ & $44.9 \pm 12.7$ \\
\hline Sexed-3 & $16.5 \pm 4.1^{\mathrm{A}}$ & $28.7 \pm 7.07^{\mathrm{B}}$ & $29.7 \pm 8.9^{\mathrm{B}}$ & $51.2 \pm 7.4^{\mathrm{A}}$ & $33.14 \pm 3.5$ & $26.5 \pm 3.5^{\mathrm{B}}$ & $1.4 \pm 1.0$ & $2.2 \pm 0.43$ & $2.2 \pm 1.4$ & $30.8 \pm 4.5$ & $35.9 \pm 8.4$ & $41.5 \pm 11.04$ \\
\hline Sexed-4 & $18.8 \pm 4.2$ & $28.8 \pm 7.7$ & $26.3 \pm 5.5$ & $46.0 \pm 7.2^{\mathrm{bA}}$ & $31.8 \pm 1.9$ & $25.8 \pm 1.3^{\mathrm{B}}$ & $2.3 \pm 1.8$ & $1.8 \pm 0.6$ & $1.8 \pm 0.8$ & $32.6 \pm 7.0$ & $37.4 \pm 7.7$ & $46.0 \pm 6.0$ \\
\hline Sexed-5 & $15.6 \pm 3.1 \mathrm{~A}$ & $28.4 \pm 4.4 \mathrm{~B}$ & $27.8 \pm 5.6 \mathrm{~B}$ & $51.6 \pm 7.9 \mathrm{~A}$ & $31.9 \pm 2.2$ & $27.2 \pm 3.2 \mathrm{~B}$ & $1.8 \pm 1.8$ & $1.9 \pm 0.7$ & $1.2 \pm 0.5$ & $30.8 \pm 7.9 \mathrm{~A}$ & $37.7 \pm 5.1$ & $43.6 \pm 8.4 \mathrm{~B}$ \\
\hline Sexed-6 & $15.3 \pm 2.2^{\mathrm{A}}$ & $29.9 \pm 4.7^{\mathrm{B}}$ & $29.8 \pm 5.6^{\mathrm{B}}$ & $51.7 \pm 4.5^{\mathrm{A}}$ & $33.5 \pm 3.3^{\mathrm{B}}$ & $26.4 \pm 3.7^{\mathrm{C}}$ & $1.8 \pm 1.9$ & $2.2 \pm 1.0$ & $1.4 \pm 0.6$ & $31.1 \pm 5.6^{\mathrm{A}}$ & $34.3 \pm 5.5$ & $42.1 \pm 7.0^{\mathrm{B}}$ \\
\hline
\end{tabular}




\subsubsection{Experiment 3: Tubal insemination of sex-sorted frozen/thawed boar spermatozoa}

The mean motility of the thawed spermatozoa prior to insemination was $39.3 \pm 4.7 \%$. From six inseminated gilts 70 embryos were re-flushed. In total $37(52,5 \%)$ embryos were fertilized (based on morphological analysis and all counts). From these 16 embryos $(22,9 \%)$ remained in early embryo stages (2-8 cells), whereas 19 embryos (51,4\% of fertilized embryos or $27,1 \%$ of all re-flushed embryos) developed to blastocyst stages and had in average 64.4 cells.

\subsection{Discussion}

Fresh sex-sorted porcine spermatozoa have successfully been used to produce piglets in swine after artificial insemination with methods applicable on farm (Martinez et al. 2001, Rath et al. 2003a, Grossfeld et al. 2005). Additionally, it is well accepted that cryo-preserved porcine semen allows to produce offspring by normal AI (Johnson 1985) but so far a combination of both methods failed to produce piglets. Only one paper reports a successful surgical insemination of 200.000 frozen/thawed sex-sorted spermatozoa into the oviduct that resulted in the birth of two piglets (Johnson et al. 2000).

In the present study a combination of different antioxidative additives added to semen preservation media was tested for fresh and frozen sexed spermatozoa. Therefore, sperm characteristics were tested and the fertilizing ability of sex sorted spermatozoa was proved by surgical tubal insemination.

The results of this study show that antioxidants added to Androhep ${ }^{\mathrm{TM}}$ have no significant effect on the preservation of motility and morphology during liquid storage of boar semen for up to five days. This was true for unsorted as well as sexsorted spermatozoa. The only difference was detectable after 120 hours of storage between unsorted and sex-sorted semen, where the latter group showed a significantly decreased motility and acrosome morphology. Such effects on sperm quality and fertility have been described previously in several trials with porcine semen as well as in other species (Johnson et al. 2005a, Garner 2006). Reduced fertility results from physical load on sperm during the flow cytometrical separation process were reported from several authors. The effects included pre-capacitation 
(Hollinshead et al. 2003, Knöppel 2001, Maxwell et al. 1998), which may be caused by removal of protective substances due to a high dilution during sorting. Motility of spermatozoa was also negatively affected as has been shown in this study and by others (Hollinshead et al. 2003, Rath et al. 2003b). Reasons for a decrease in motility can be related either to the hydro-dynamic differential pressure (Suh and Schenk 2003) or in the electro-static field, necessary to split X- and Y-bearing spermatozoa in two populations. This may cause temporary membrane polarisation of the midpiece of the sperm tail and disturbs ATP synthesis (Klinc 2005). The laser light was also correlated with inhibition of motility and immobilization of spermatozoa (Montag et al. 2000). It was found that exposure to laser light accelerates $\mathrm{Ca}^{2+}$ transport into irradiated bull spermatozoa (Breitbart et al. 1996), enhances $\mathrm{Ca}^{2+}$ binding to plasma membranes and inhibits $\mathrm{Ca}^{2+}$ uptake by mitochondria (Lubart et al. 1997). These findings may explain the lowered motility and membrane status of the sex-sorted sperm samples in this study although the effects were rather low as compared to the unsorted control group.

Reactive oxygen species (ROS) effect sperm integrity negatively and have been found to be build up at several steps during flow cytometrical sorting. These steps include incubation for up to 1.5 hours at $34-37^{\circ} \mathrm{C}$ (Alvarez and Storey 1985), high dilution with the sheath-fluid (Maxwell et al. 1998), pressure changes (Suh and Schenk 2003) exposure to laser light and centrifugation after sorting (Shekarriz et al. 1995). Especially porcine spermatozoa are prone to peroxidation due to their high content of polyunsaturated fatty acids (Aitken et al. 1989, Cerolini et al. 2000). The negative effects of ROS include inhibition of sperm motility and membrane damages, especially of the acrosome (De Lamirande and Gagnon 1992b, Whittington and Ford 1998).

Although antioxidative additives had been added and should have minimized the effects of ROS, their impact seems to be minimal in comparison to those reported for other species like the bovine (Klinc and Rath 2007, Klinc et al. 2007). As Androhep ${ }^{\mathrm{TM}}$ was used in the present experiments for incubation and sorting and ROS may have been already intercepted by the ingredients of the extender that include BSA and a strong buffer system.

If spermatozoa are not only flow cytometrically sorted but additionally frozen and thawed in liquid nitrogen, another source for ROS is added to the process. Cooling 
and freezing can cause lipid peroxidation as well (Chatterjee and Gagnon 2001a). It has been shown in the second experiment that sex-sorted spermatozoa, frozen at a concentration of $40 \times 10^{6}$ sperm per $\mathrm{ml}$ without any antioxidants, had a significantly decreased motility than any other treatment group. Although the effect was not significant, sex-sorted spermatozoa frozen at a concentration of $80 \times 10^{6}$ sperm per $\mathrm{ml}$ in the presence of antioxidants, showed the highest motility. There were no significant differences in the sperm morphology between the treatment groups, indicating that the sorting process itself prior to freezing is mild enough to allow the sperm membrane system to withstand the freezing forces.

In opposite, if antioxidants were absent, a significant difference was found between unsorted and sorted spermatozoa at a concentration of $40 \times 10^{6}$ sperm per $\mathrm{ml}$ after freezing and thawing (Sexed-1 vs. Control-1) again indirectly indicating a slight beneficial effect of antioxidants for sorted spermatozoa. This difference could not be detected, when sorted and unsorted samples without additives, but with different sperm concentration (Control-1 vs. Sexed-1 vs. Sexed-4) were compared, indicating a possible concentration effect.

The scavenging effect against ROS were more obvious in other species (Klinc 2005) and with other antioxidants in the porcine. BHT (butylated hydroxytoluene) improved the resistance against cold shock (Bamba and Cran 1992), produced a higher sperm survival after freezing, a lower lipid oxidation and an improved embryo development after IVF (Roca et al. 2004). The addition of Catalase to freezing media for boar semen significantly improved the post thawing quality in boar semen (Roca et al. 2005a) but failed to do so in the equine (Baumber et al. 2005). Also the vitamin E analogue Trolox improved the post thawing quality in boar semen as shown in Chapter I and by Pena et al. (2003b, 2004b). In order to evaluate possible positive effects of these and other antioxidants further research should be directed to further combinations and concentrations of antioxidants.

In order to prove the fertilizing capacity of sex-sorted frozen spermatozoa a surgical insemination trial was performed. In opposite to the experiment by Krueger et al. (1999) semen was not inseminated into the tip of the uterine horn but directly into the ampoule of the oviduct. The idea behind this was to circumvent the utero-tubal junction that is know to have a sperm selective ability (Hunter 1988, Mburu 1997, Suarez et al. 1991, Fazeli et al. 1999). 
The earlier experiments by Johnson et al. (1991) had indicated the feasibility to produce offspring by tubal AI when gilts were inseminated with 200.000 sex-sorted frozen spermatozoa and two piglets were obtained. Therefore, six gilts were tubally inseminated with $4 \times 10^{6}$ spermatozoa. Altogether $27.1 \%$ of all re-flushed embryos developed to blastocyst stages and proved in principle the successful surgical insemination into the oviduct with sex-sorted and frozen/thawed spermatozoa.

It can be concluded from the results of the experiments that sex-sorting and freezing of porcine spermatozoa causes a reasonable stress to the cell organelles. Although reactive oxygen species may be responsible for a larger part of the negative effects other mechanisms of sperm damage may cause significant sperm damages as well. This may be one reason why the antioxidants did not significantly improve the semen quality of porcine spermatozoa after sex-sorting and freezing and thawing. But it allowed the first successful fertilization after surgical tubal insemination. 


\section{General discussion and conclusions}

The results of the experiments in this study have confirmed that freezing and thawing of spermatozoa reduces the sperm motility and increases the percentage of membrane and acrosomal damaged spermatozoa in boar semen. Similar effects have been observed after flow cytometrical sperm sexing. In the presented experiments both insults to spermatozoa have been combined and possible beneficial effects of boar individual freezing speeds and of antioxidant additives in sperm media either during storage in liquid as well as in frozen state were tested.

Improvement of sperm quality after freezing, can be achieved by boar selection, as an animal variety in resistance of spermatozoa to survive freezing exists (Medrano 1998, Holt et al. 2005). If animals are pre-selected for cryo-resistance, the influence of changes in freezing curves is minimized, as has been shown in this study. The sperm quality of only one of four boars showed improvement, when spermatozoa where frozen in three different freezing speeds.

In the presence of Pyruvate, the antioxidants Catalase and Mercaptoethanol had no effect on the sperm quality of semen stored in liquid state. The additives only had a beneficial effect on cryo-preservation in unsorted semen directly after thawing, whereby the presence of Trolox alone did not show a significant positive effect. In contrary to experiments of other research groups, using antioxidants as well (Klinc 2005, Pena et al. 2004b, Cerolini et al. 2001), the additives used in this experiment had no positive effect on the sperm morphological status, nor on the membrane or acrosomal status. This was the case in the experiments with unsexed as well as sexed semen in either fresh or frozen semen. Although boar spermatozoa show a very high content in unsaturated fatty acids in their sperm membranes, the ROS scavenging effects of the used substances were not able to limit damages. Even with doubled concentrations of Pyruvate and the antioxidants Catalase and Mercaptoethanol, no protective effect could be detected in the second experiment of Chapter 2. Further research with different antioxidants and concentrations should evaluate, if possible 
negative effects of reactive oxygen species can be prevented during sexing and freezing.

However, other damages than that caused by reactive oxygen species could not be excluded in this study. The laser light involved in the sorting process has been shown in other trials, to cause damages as well. It has been found that sperm motility was inhibited (Montag et al. 2000) and the $\mathrm{Ca}^{2+}$ metabolism was negatively affected (Breitbart et al. 1996, Lubart et al. 1997) by exposure to laser light. The pressure changes during sorting and the electro-static field may have a negative influence on spermatozoa as well. Further research in this area is needed as well, to further evaluate the damages to spermatozoa during sorting in order to prevent them.

In conclusion, the antioxidants Catalase and Mercaptoethanol in presence of Pyruvate can have a positive effect on sperm motility after flow cytometrical sorting and freezing directly after thawing. And the additives allowed the first fertilization after surgical tubal insemination in gilts. 


\section{Summary}

\section{Experiments to improve the quality of sex-sorted fresh and frozen porcine spermatozoa}

For several reasons the demand for sex sorted porcine spermatozoa has been expressed. This includes advantages for herd management, improved production efficiency, foreseeable restrictions of male castration and gene preservation programmes. Due to the high costs for the sex-sorting process and the reduced storage time in liquid state, freezing of sex-sorted spermatozoa in liquid nitrogen would be very advantageous if the post thawing sperm quality would be acceptable. Therefore, the ultimate goal of the present study was to adapted existing freezing methods for porcine spermatozoa to the post sort processing of sexed spermatozoa.

In two chapters five trials were conducted, in order to improve the quality of frozenand sex-sorted spermatozoa.

In presence of Sodium Pyruvate, the addition of the ROS scavengers Catalase and Mercaptoethanol, and Vitamin E analogue Trolox to cooling and freezing media of boar semen was tested. Frozen spermatozoa were incubated for up to six hours after thawing and motility, morphological status, membrane integrity, and acrosomal status via triple staining in a flow cytometer (SYTO-17/FITC-PNA/PI) were recorded. In a second trial the influence of individual freezing curves for four boars were tested. Frozen spermatozoa were incubated at $38^{\circ} \mathrm{C}$ for up to six after thawing and motility as well as morphological status were recorded. Also membrane integrity and acrosome status via triple staining in a flowcytometer (SYTO-17/FITC-PNA/PI) were recorded 0 and 2 hours after thawing.

In the second chapter the addition of Catalase and Mercaptoethanol to media for fresh semen preservation and to cooling and freezing media for cryopreservation were tested. It was also tested if sex-sorted and frozen-thawed porcine spermatozoa can be used for surgical insemination into the tip of the uterine horn. Initially fresh and sex-sorted semen were stored for up to five days with or without the addition of 
Pyruvate, Catalase and Mercaptoethanol to the storage media. Semen samples were put in a thermo resistance test at $38^{\circ} \mathrm{C}$ for two hours after storage at $15^{\circ} \mathrm{C}$ for 0,24 and 120 hours and the motility as well as the morphological status after 120 hours were recorded.

In a subsequent trial two different concentrations of Pyruvate, Catalase and Mercaptoethanol were added to cooling and freezing media in two different sperm concentrations (40 and $80 \times 10^{6}$ sperm per $\mathrm{ml}$ ), and motility as well as the morphological status were recorded in a thermo resistance test. Also the membrane integrity and acrosome status were recorded employing a flow cytometrical analysis with a triple staining protocol (SYTO-17/FITC-PNA/PI) 0, 3 and 6 hours after thawing.

Finally, six gilts were inseminated surgically into the ampoule of the oviduct with four million sex-sorted spermatozoa frozen and thawed with addition of Pyruvate, Catalase and Mercaptoethanol. Gilts were slaughtered 48 hours later and the embryos were reflushed from the genital tract.

In summary the following results were obtained.

Directly after thawing fresh spermatozoa frozen in the presence of antioxidants showed a significantly $(\mathrm{P} \leq 0.05)$ improved motility compared to spermatozoa frozen without additives. The percentage of normal apical ridges and the gross morphology did not differ significantly between the treatment groups. After flow cytometrical analysis of membrane integrity and acrosome status no significant differences could be detected among treatment groups, but the percentage of viable spermatozoa decreased and the percentage of acrosome damaged spermatozoa increased in eleven of twelve sperm subgroups within one respective treatment groups during incubation time.

After the evaluation of different freezing curves for individual animals significant differences could only be detected for one boar directly after thawing. The spermatozoa of this boar showed a higher $(\mathrm{P} \leq 0.05)$ motility after being frozen with a short, instead with a long freezing curve. The analysis of the morphological status showed no significant differences in all boars between the different freezing curves. The evaluation of the viability and acrosome reaction showed that the percentage of viable, acrosome reacted spermatozoa and the percentage of membrane damaged and 
acrosome reacted spermatozoa of one boar were significantly lower in the sample frozen following the medium timed protocol than following the short and long protocol. Significant differences were also recorded in part of the treatment groups of all boars, were the percentage of viable spermatozoa decreased and the percentage of acrosomal damages increased after two hours of incubation at $38^{\circ} \mathrm{C}$.

Motility of fresh non-sorted and sex-sorted sperm samples decreased during storage at $15^{\circ} \mathrm{C}$ as well as during incubation at $38^{\circ} \mathrm{C}$ in all treatment groups. The sperm motility was higher in the non-sorted groups than in the sex-sorted groups, although the difference was only statistically significant $(\mathrm{P} \leq 0.05)$ after $120 \mathrm{~h}$ storage at $15^{\circ} \mathrm{C}$ and $15 \mathrm{~min}$ incubation at $38^{\circ} \mathrm{C}$. The addition of antioxidants had a slightly beneficial effect on the motility of sex-sorted spermatozoa, but the difference was not statistically significant. The percentage of acrosomal damaged spermatozoa was significantly $(\mathrm{P} \leq 0.05)$ higher in the sex-sorted spermatozoa than in the fresh semen samples, but did not differ between the samples stored with or without additives.

In the subsequent experiment $0 \mathrm{~h}$ after thawing only the sex-sorted samples frozen and thawed in sperm concentration of $80 \times 10^{6} / \mathrm{ml}$ without addition of Pyruvate, Catalase and Mercaptoethanol showed a significant $(\mathrm{P} \leq 0.05)$ lower motility than all other groups. All other groups showed no significant differences. However, the nonsorted semen samples showed a elevated motility when compared with sex-sorted samples, but from $1 \mathrm{~h}$ after thawing up until $6 \mathrm{~h}$ no statistically significant differences could be measured in the sperm motility between all treatment groups. No significant differences in the morphological status of the spermatozoa could be detected between all treatment groups. Directly after thawing the non-sorted sperm frozen without antioxidants showed a significantly $(\mathrm{P} \leq 0.05)$ higher portion of viable sperm with intact acrosomes than the sex-sorted samples frozen without additives and $80 \times 10^{6}$ sperm per ml. Further incubation did not reveal significant differences in acrosomes. In all treatment groups the percentage of vital and acrosome intact spermatozoa decreased significantly during incubation for six hours.

The last trial proved that sex-sorted porcine spermatozoa frozen with antioxidants and Pyruvate can successfully be used to fertilize oocytes in vivo after surgical insemination. From the six gilts 70 embryos were reflushed. From these embryos $52.5 \%$ were fertilized and $27.1 \%$ developed to blastocysts stages. 
From these results it can be concluded that the addition of Pyruvate, and the antioxidants Catalase and Mercaptoethanol have only limited effect on motility of fresh, sex-sorted and frozen porcine spermatozoa and almost no effect on sperm morphology. Antioxidants did not significantly improve the quality of sex-sorted semen after either fresh or frozen storage. There may be other damages during flowcytometrical sorting that can not be prevented by the addition of the ROS scavengers. 


\section{Zusammenfassung}

\section{Experimente zur Verbesserung der Qualität von gesextem und tiefgefrorenem Ebersperma}

Aus verschiedenen Gründen gibt es einen Bedarf für gesextes Ebersperma. Einige dieser Gründe sind Vorteile im Herdenmanagement, verbesserte Produktionseffizienz, Restriktionen bei der Kastration männlicher Tiere und Programme zur Genpräservation. Aufgrund der hohen Kosten für den Sortierprozess und der geringen Lagerdauer in Flüssig konserviertem Zustand, würde das Tiefgefrieren von gesextem Sperma große Vorteile bringen, wenn die Spermaqualität nach dem Auftauen akzeptabel wäre. Daher war das Ziel dieser Studie existierende Tiefgefriermethoden für Schweinesperma an die Verarbeitung von flowzytometrisch gesextem Sperma anzupassen.

In zwei Abschnitten wurden fünf Versuche durchgeführt, um die Qualität von tiefgefrorenem und gesextem Sperma zu verbessern.

Im ersten Abschnitt wurde zunächst der Zusatz von Na-Pyruvat, Catalase und Mercaptoethanol und des Vitamin E-Analogs Trolox zum Kühl- und Gefrierverdünner von Ebersperma getestet. Die tiefgefrorenen und aufgetauten Spermien wurden bis zu sechs Stunden nach dem Auftauen inkubiert und die Motilität, der morphologische Status und die Membranintegrität und der Akrosomstatus wurden mittels Färbung mit SYTO-17/FITC-PNA/PI im Flowzytometer getestet. In einem zweiten Versuch wurde der Einfluss von individuellen Einfrierkurven für vier Eber getestet. Die tiefgefrorenen und aufgetauten Spermien wurden bei $38^{\circ} \mathrm{C}$ für bis zu sechs Stunden nach dem Auftauen inkubiert und die Motiliät, der morphologische Status wurde ebenso erfasst. Ebenso wurde die Membranintegrität und der Akrosomstatus mittels Färbung mit SYTO17/FITC-PNA/PI im Flowzytometer getestet.

Im zweiten Abschnitt wurde der Zusatz von Na-Pyruvat, Catalase und Mercaptoethanol zu flüssig konserviertem frischem und gesextem Sperma und zum 
Kühl- und Gefrierverdünner für die Spermatiefgefrierung getestet. Ebenso wurde getestet, ob gesexte und tiefgefrorene Eberspermien für die chirurgische Besamung in die Uterushornspitze genutzt werden können. Zunächst wurden frische oder gesexte Eberspermien bis zu fünf Tage mit oder ohne Zusatz von Pyruvat, Catalase und Mercaptoethanol zum Konservierungsmedium gelagert. Nach Lagerung für 0 Std., 24 Std. oder 120 Std. wurden Proben entnommen und für bis zu zwei Stunden bei $38^{\circ} \mathrm{C}$ gelagert. Die Motilität und der morphologische Status nach $120 \mathrm{Std}$. wurden erfasst.

In einem folgenden Versuch wurden zwei verschiedenen Konzentrationen der Antioxidantien zum Kühl- und Gefrierverdünner und zwei verschiedene Spermakonzentrationen von ungesextem und gesextem Ebersperma getestet. Die Motilität im Thermoresistenztest und der morphologische Status wurden erfasst. Ebenso wurden die Membranintegrität und der Akrosomstatus mittels Färbung mit SYTO-17/FITC-PNA/PI im Flowzytometer nach 0 Std., 3 Std. und 6 Std. nach dem Auftauen getestet. Zuletzt wurden sechs Jungsauen chirurgisch mit vier Millionen gesexten und unter Zusatz von Antioxidantien tiefgefrorenen Eberspermien in die Eileiterampulle besamt. Die Jungsauen wurden 48 Std. später geschlachtet und die Embryonen wurden aus dem Genitaltrakt zurückgespült.

Die folgenden Ergebnisse lassen sich zusammenfassen:

Im ersten Abschnitt zeigte das Vorhandensein von Na-Pyruvat, Catalase und Mercaptoethanol zum Kühl- und Gefrierverdünner eine signifikant $(\mathrm{P} \leq 0,05)$ verbesserte Spermienmotilität direkt nach dem Auftauen verglichen mit Sperma, das ohne jegliche Zusätze eingefroren wurde. Der Prozentsatz von Spermien mit normalem apikalem Rand und gesamter morphologisch veränderter Spermien unterschied sich nicht zwischen Gruppen. Ebenso zeigte die flowzytometrische Analyse der Membranintegrität und des Akrosomstatus keine signifikanten Unterschiede. Allerdings sank der Prozentsatz von lebenden Spermien und stieg der Prozentanteil von Akrosom reagierten Spermien signifikant $(\mathrm{P} \leq 0,05)$ innerhalb von elf von 12 Behandlungsgruppen im Zeitverlauf an.

Nach der Analyse von drei verschiedenen Einfrierkurven für die vier Eber konnten signifikante $(\mathrm{P} \leq 0,05)$ Unterschiede zwischen den Einfrierkurven nur bei einem Eber festgestellt werden. Die Spermien dieses Ebers zeigten eine höhere Motilität nach 
dem Auftauen, nachdem sie mit einer kurzen, anstatt einer langen Einfrierkurve tiefgefroren wurden. Die Auswertung des morphologischen Status der Spermien zeigte keine signifikanten Unterschiede zwischen den jeweiligen Einfrierkurven. Die Analyse der Spermien im Flowzytometer zeigten einen niedrigeren Anteil viabiler und Akrosom reagierter Spermien und einen signifikant $(\mathrm{P} \leq 0,05)$ niedrigeren Anteil Membran geschädigter und Akrosom reagierter Spermien bei einem Eber dessen Spermien mit einer mittleren Einfrierkurve, anstatt der kurzen oder langen Kurve eingefroren wurden. Signifikante $(\mathrm{P} \leq 0,05)$ Unterschiede wurden in Teilen der Versuchsgruppen bei allen Ebern gefunden, wo der Prozentanteil viabiler Spermien absank und der Prozentanteil Akrosom reagierter Spermien anstieg, jeweils nach zweistündiger Inkubation bei $38^{\circ} \mathrm{C}$.

Im zweiten Abschnitt sank die Motilität von frischen ungesexten und gesexten Eberspermien während der Lagerung bei $15^{\circ} \mathrm{C}$ und bei der Inkubation bei $38^{\circ} \mathrm{C}$ in allen Behandlungsgruppen ab. Die Spermamotilität war höher in den ungesexten, als in den gesexten Versuchsgruppen, allerdings war dieser Unterschied nur statistisch signifikant $(\mathrm{P} \leq 0,05)$ nach einer Lagerdauer von $120 \mathrm{Std}$. bei $15^{\circ} \mathrm{C}$ und 15 Minuten Inkubation bei $38^{\circ} \mathrm{C}$. Der Zusatz von Pyruvat, Catalase und Mercaptoethanol zeigte einen leichten positiven Effekt auf die Motilität bei den gesexten Spermien, aber die Differenz war nicht signifikant. Der Anteil von Akrosom geschädigten Spermien nach morphologischer Analyse war in den gesexten Versuchsgruppen signifikant $(\mathrm{P} \leq 0,05)$ höher als in den ungesexten Versuchsgruppen, unterschied sich aber nicht zwischen Gruppen mit oder ohne Zusatz von Pyruvat, Catalase und Mercaptoethanol. Im folgenden Experiment direkt nach dem Auftauen zeigten nur gesexte Spermien, die bei einer Spermakonzentration von 80 Mio. Spermien pro ml ohne Zusätze eingefroren wurden, eine signifikant $(\mathrm{P} \leq 0,05)$ niedrigere Motilität als alle anderen Versuchsgruppen. Zwischen allen anderen Gruppen bestanden keine signifikanten Unterschiede. Die ungesexten Versuchsgruppen zeigten eine höhere Motilität als die gesexten Versuchsgruppen. Dieser Unterschied war aber von einer Stunde bis sechs Stunden nach dem Auftauen nicht signifikant. Bei der morphologischen Beurteilung der Spermien konnten ebenfalls keine signifikanten Unterschiede festgestellt werden. Direkt nach dem Auftauen zeigte die Gruppe unsortierter, mit einer Konzentration von 40 Mio. Spermien pro $\mathrm{ml}$ und ohne Zusätze eingefrorene Gruppe einen 
signifikant $(\mathrm{P} \leq 0,05)$ höheren Prozentsatz von viabilen Spermien mit intakten Akrosomen als gesexte Spermien, mit Zusatz von Pyruvat, Catalase und Mercaptoethanol, die bei einer Konzentration von 80 Mio. Spermien pro ml eingefroren wurden. Nach einer Inkubation von einer Stunde und mehr konnten keine signifikanten Unterschiede mehr festgestellt werden. In allen Versuchsgruppen sank der Anteil viabiler und Akrosom intakter Spermien signifikant $(\mathrm{P} \leq 0,05)$ während der Inkubation ab.

Im letzten Versuch konnte nachgewiesen werden, dass gesexte Eberspermien, die mittels Zusatz von Pyruvat, Catalase und Mercaptoethanol tiefgefroren wurden erfolgreich Oozyten nach chirurgischer Besamung in vivo befruchten können. Von sechs Jungsauen konnten 70 Embryonen zurückgespült werden. Von diesen Embryonen waren 52,5\% befruchtet und 27,1\% entwickelten sich zu BlastozystenStadien.

Zusammengefasst hat der Zusatz von Pyruvat und der Antioxidantien Catalase und Mercaptoethanol zu Verdünnermedien nur einen geringen Effekt auf frische, gesexte oder tiefgefrorenen Eberspermien. Der Zusatz kann die Motilität der Spermien verbessern, hat aber nur einen geringen oder keinen Effekt auf die Spermienmorphologie. Der Zusatz von Pyruvat, Catalase und Mercaptoethanol verbesserte die Qualität von gesextem und flüssig konserviertem oder tiefgefrorenem Sperma nicht signifikant. Möglicherweise gibt es andere Schädigungen beim Spermasexing, die nicht durch den Zusatz von Pyruvat, Catalase und Mercaptoethanol verhindert werden können. 


\section{References}

Acott T.S., Hoskins D.D. (1978)

Bovine sperm forward motility protein. Partial purification and characterization. J Biol Chem, 253, 6744-6750

Aitken R.J., Clarkson J.S., Fishel S. (1989)

Generation of reactive oxygen species, lipid peroxidation, and human sperm function.

Biol Reprod, 41, 183-197

Aitken R.J., Fisher H.M., Fulton N., Gomez E., Knox W., Lewis B., Irvine S. (1997)

Reactive oxygen species generation by human spermatozoa is induced by exogenous NADPH and inhibited by the flavoprotein inhibitors diphenylene iodonium and quinacrine.

Mol Reprod Dev, 47, 468-482

\section{Aitken R.J., Gordon E., Harkiss D., Twigg J.P., Milne P., Jennings Z., Irvine} D.S. (1998)

Relative impact of oxidative stress on the functional competence and genomic integrity of human spermatozoa.

Biol Reprod, 59, 1037-1046

Almlid T., Clark R.N., Pursel V.G., Johnson L.A. (1989a)

Effectiveness of in vitro methods for predicting in vivo fertilization capacity of boar spermatozoa cryopreserved with $2 \%$ or $4 \%$ glycerol.

Zuchthygiene, 24, 8-15

Almlid T., Clarke R.N., Pursel V.G., Johnson L.A. (1989b)

Effectiveness of in vitro methods for predicting in vivo fertilizing capacity of boar spermatozoa cryopreserved with $2 \%$ or $4 \%$ glycerol.

Zuchthygiene, 24, 8-15

Almlid T., Johnson L.A. (1988)

Effects of glycerol concentration, equilibration time and temperature of glycerol addition on post-thaw viability of boar spermatozoa frozen in straws.

J Anim Sci, 66, 2899-2905

Almlid T., Stavne S.E., Johnson L.A. (1987)

Fertility evaluation of the straw freezing technique for boar semen under practical artificial insemination conditions.

Zuchthygiene, 22, 193-202 
Alvarez A., Storey B.T. (1992)

Evidence for increased lipid peroxidative damage and loss of superoxide dismutase activity as a mode of sublethal cryodamage to human sperm during cryopreservation. $J$ Androl, 13, 232-241

Alvarez J.G., Storey B.T. (1985)

Spontaneous lipid peroxidation in rabbit and mouse epididymal spermatozoa: dependence of rate on temperature and oxygen concentration.

Biol.Reprod., 32, 342

Alvarez J.G., Storey B.T. (1993)

Evidence that membrane stress contributes more than lipid peroxidation to sublethal cryodamage in cryopreserved human sperm: glycerol and other polyols as sole cryoprotectant.

J Androl, 14, 199-209

Amann R.P., Katz D.F. (2004)

Reflections on CASA after 25 years.

J Androl, 25, 317-325

Ardon F., Dohring A., Le Thi X., Weitze K.F., Waberski D. (2003)

Assessing in vivo fertilizing capacity of liquid-preserved boar semen according to the 'Hanover gilt model'.

Reprod Dom Anim, 38, 161-165

Ashworth P.J., Harrison R.A., Miller N.G., Plummer J.M., Watson P.F. (1994) Survival of ram spermatozoa at high dilution: protective effect of simple constituents of culture media as compared with seminal plasma.

Reprod Fertil Dev, 6, 173-180

Ashworth P.J., Harrison R.A., Miller N.G., Plummer J.M., Watson P.F. (1995) Flow cytometric detection of bicarbonate-induced changes in lectin binding in boar and ram sperm populations.

Mol Reprod Dev, 40, 164-176

Askari H.A., Check J.H., Peymer N., Bollendorf A. (1994a)

Effect of natural antioxidants tocopherol and ascorbic acids in maintenance of sperm activity during freeze-thaw process.

Arch.Androl, 33, 11

Askari H.A., Check J.H., Peymer N., Bollendorf A. (1994b)

Effect of natural antioxidants tocopherol and ascorbic acids in maintenance of sperm activity during freeze-thaw process.

Arch Androl, 33, 11-15

Austin C.R. (1951)

Observation on the penetration of sperm into the mammalian egg.

Aust J Sci Res, 4, 581-596 
Bader H. (1964)

Untersuchungen über den Einfluss unterschiedlicher Abkühlzeiten beim Tiefgefrieren von Ebersperma auf die Bewegungsaktivität der Samenzellen.

Dissertation, Tierärztliche Hochschule Hannover, Hannover

Bailey J.L., Bilodeau J.F., Cormier N. (2000)

Semen cryopreservation in domestic animals: a damaging and capacitating phenomenon.

J Androl, 21, 1-7

Bailey J.L., Buhr M.M. (1994)

The impact of cryopreservation on $\mathrm{Ca} 2+$ regulation by bovine spermatozoa. Can J Anim Sci, 74, 45-52

Bailey J.L., Storey B.T. (1994)

Calcium influx into mouse spermatozoa activated by solubilized mouse zona pellucida, monitored with the calcium fluorescent indicator, fluo-3. Inhibition of the influx by three inhibitors of the zona pellucida induced acrosome reaction: tyrphostin A48, pertussis toxin, and 3-quinuclidinyl benzilate.

Mol Reprod Dev, 39, 297-308

Ball B.A., Medina V., Gravance C.G., Baumbe J. (2001)

Effect of antioxidants on preservation of motility,viability and acrosomal integrity of equine spermatozoa during storage at 5 degrees $\mathrm{C}$.

Theriogenology, 56, 577-589

Bamba K., Cran D.G. (1992)

Effects of treatment with butylated hydroxytoluene on the susceptibility of boar spermatozoa to cold stress and dilution.

J Reprod Fertil, 95, 69-77

Bamba K., Taniguchi T., Kojima J., Iida I. (1968)

Studies on deep freezing of boar semen. VI. Effects of rapid freezing on survival of boar spermatozoa.

Jap. J. Anim. Reprod., 40, 60

Barlow P., Vosa C.G. (1970)

The Y chromosome in human spermatozoa.

Nature, 226, 961-962

Bathgate R. (2004)

Studies on the cryopreservation of boar spermatozoa and its integration into the Assisted Reproductive Technologies.

Thesis, Faculty of Veterinary Science, University of Sydney, Sydney 
Bathgate R., Eriksson B., Maxwell W.M., Evans G. (2003)

Low dose deep intrauterine insemination of sows with fresh and frozen-thawed spermatozoa.

Theriogenology, 63, 553 Abstract

Bathgate R., Maxwell W.M., Evans G. (2007)

Effects of platelet-activating factor and platelet-activating factor: acetylhydrolase on in vitro post-thaw boar sperm parameters.

Theriogenology, 67, 886-892

Bathgate R., Maxwell W.M.C., Evans G. (2006)

Studies on the Effect of Supplementing Boar Semen Cryopreservation Media with Different Avian Egg Yolk Types on in Vitro Post-thaw Sperm Quality.

Reproduction in Domestic Animals, 41, 68-73

Bathgate R., Morton K.M., Eriksson B.M., Rath D., Sieg B., Chami O., Stojanov T., Maxwell W.M., et al. (2005)

Production of porcine embryos of a predicted sex after in vitro fertilitsation of in vitro matured oocytes with sex-sorted frozen-thawed boar sperm.

Reprod Fertil Dev, 17, 303 Abstract

Bathla H., Sidhu K.S. (1998)

Localisation of low molecular weight sperm antigens during capacitation and acrosome reaction.

Anim Reprod Sci, 54, 55-64

Baumber J., Ball B.A., Linfor J.J. (2005)

Assessment of the cryopreservation of equine spermatozoa in the presence of enzyme scavengers and antioxidants.

Am $J$ Vet Res, $\underline{66}$, 772-779

Baumber J., Ball B.A., Linfor J.J., Meyers S.A. (2003)

Reactive oxygen species and cryopreservation promote DNA fragmentation in equine spermatozoa.

J Androl, 24, 621-628

Beconi M.T., Affranchino M.A., Schang L.M., Beorlegui N.B. (1991)

Influence of antioxidants on SOD activity in bovine sperm.

Biochem Int, 23, 545-553

Beconi M.T., Francia C.R., Mora N.G., Affranchino M.A. (1993)

Effect of natural antioxidants on frozen bovine semen preservation.

Theriogenology, $\underline{40}, 841$

Bedford J.M. (1967)

Effecht of duct ligation on the fertilizing ability of spermatozoa from different regions of the rabbit epididymis.

J Exp Zool, 166, 271-282 
Bedford J.M. (1969)

Limitation of the uterus in the development of the fertilizing ability (capacitation) of spermatzoa.

J Reprod Fertil, 8 (Suppl), 19-26

Bedford J.M. (1970)

Sperm capacitation and fertilization in mammals.

Biol Reprod Suppl, 2, 128-158

Bedford J.M. (1994)

The contraceptive potential of fertilization: a physiological perspective.

Hum Reprod, 9, 842-858

Berger B., Fischerleitner F. (1992)

On deep freezing of boar semen - investigations on the effect of different straw volumes, methods of freezing and thawing extenders.

Reprod Dom. Anim, 266-270

Berger T., Parker K. (1989)

Modification of the zona-free hamster ova bioassay of boar sperm fertility and correlation with in vivo fertility.

Gamete Res, 22, 385-397

Bertani G.R., Scheid I.R., Fialho F.B., Rubin M.I.B., Wentz I., Goncalves P.B.D. (1996)

Preovulatory insemination with fresh or frozen semen on embryo viability and early pregnancy rates in gilts.

Reprod Dom. Anim, 31, 307-308

Betteridge K.J. (1984)

The folklore of sexing.

Theriogenology, 21, 3

Bilodeau J.F., Blanchette S., Cormier N., Sirard M.A. (2002)

Reactive oxygen species-mediated loss of bovine sperm motility in egg yolk Tris extender: protection by pyruvate, metal chelators and bovine liver or oviductal fluid catalase.

Theriogenology, 57, 1105-1122

Boe-Hansen G.B., Ersboll A.K., Greve T., Christensen P. (2005)

Increasing storage time of extended boar semen reduces sperm DNA integrity.

Theriogenology, 63, 2006-2019

Boilard M., Bailey J., Collin S., Dufour M., Sirard M.A. (2002)

Effect of bovine oviduct epithelial cell apical plasma membranes on sperm function assessed by a novel flow cytometric approach.

Biol Reprod, 67, 1125-1132 
Bolarin A., Roca J., Rodriguez-Martinez H., Hernandez M., Vazquez J.M., Martinez E.A. (2006)

Dissimilarities in sows' ovarian status at the insemination time could explain differences in fertility between farms when frozen-thawed semen is used.

Theriogenology, 65, 669-680

Bouvet J.P., Couderc J., Pillot J. (1987)

In vivo and in vitro immunosuppressions in mice by a $100-110-\mathrm{Kd}$ fraction from boar seminal plasma.

Am J Reprod Immunol Microbiol, 14, 135-140

Boveris A. (1977)

Mitochondrial production of superoxide radical and hydrogen peroxide.

Adv Exp Med Biol, 78, 67-82

Brackett B.G., Server J.B. (1970)

Capacitation of rabbit spermatozoa in the uterus.

Fertil Steril, 21, 687-695

Breininger E., Beorlegui N.B., O'flaherty C.M., Beconi M.T. (2005)

Alpha-tocopherol improves biochemical and dynamic parameters in cryopreserved boar semen.

Theriogenology, 63, 2126-2135

Breitbart H., Levinshal T., Cohen N., Friedmann H., Lubart R. (1996)

Changes in calcium transport in mammalian sperm mitochondria and plasma membrane irridated at $633 \mathrm{~nm}$ (HeNe laser).

J Photocem Photobiol, B 34, 117-121

Brezezinska-Slebodzinska E., Slebodzinski A.B., Pietras B., Wieczorek G. (1995) Antioxidant effect of vitamin $\mathrm{E}$ and glutathione on lipid peroxidation in boar semen plasma.

Biol Trace Elem Res, 47, 69-74

Brouwers J.F., Silva P.F.N., Gadella B.M. (2005)

New assays for detection and localization of endogenous lipid peroxidation products in living boar sperm after BTS dilution or after freeze-thawing.

Theriogenology, $\underline{63}, 458$

Buchanan B.R., Seidel G.E., Jr., Mccue P.M., Schenk J.L., Herickhoff L.A., Squires E.L. (2000)

Insemination of mares with low numbers of either unsexed or sexed spermatozoa.

Theriogenology, 53, 1333-1344

Buhr M.M., Canvin A.T., Bailey J.L. (1989)

Effects of semen preservation on boar spermatozoa head membranes.

Gamete Res, 23, 441-449 
Buhr M.M., Pettitt M.J. (1996)

Frozen-thawed boar sperm: isolation of membranes and fluidity measurement. IN: Johnson L.A., Rath D. \& Weitze K.F. (Eds.) Boar semen preservation III. Proceedings of the 3rd International Congress on boar semen preservation. Mariensee, Reprod. Dom. Anim. Supp1., 147-152, 147-152

Burkman L.J., Coddington C.C., Franken D.R., Krugen T.F., Rosenwaks Z., Hogen G.D. (1988)

The hemizona assay (HZA): development of a diagnostic test for the binding of human spermatozoa to the human hemizona pellucida to predict fertilization potential.

Fertil Steril, 49, 688-697

Bussalleu E., Pinart E., Yeste M., Briz M., Sancho S., Garcia-Gil N., Badia E., Bassols J., et al. (2005)

Development of a protocol for multiple staining with fluorochromes to assess the functional status of boar spermatozoa.

Microsc Res Tech, 68, 277-283

Bussiere J.F., Bertaud G., Guillouet P. (2000)

Conservation of boar semen by freezing. Evaluation in vivo and after insemination. Journees de la Recherche Porcine en France, 32, 429-432

Bwanga C.O. (1991)

Cryopreservation of boar semen. I: A literature review.

Acta Vet Scand, 32, 431-453

Bwanga C.O., Einarsson S., Rodriguez-Martinez H. (1991a)

Cryopreservation of boar semen. II: Effect of cooling rate and duration of freezing point plateau on boar semen frozen in mini- and maxi-straws and plastic bags.

Acta Vet Scand, 32, 455-461

Bwanga C.O., Hofmo P.O., Grevle I.S., Einarsson S., Rodriguez-Martinez H. (1991b)

In vivo fertilizing capacity of deep frozen boar semen packed in plastic bags and maxi-straws.

$J$ Vet Med. Series A, 38, 281-286

Calamera J.C., Fernandez P.J., Buffone M.G., Acosta A.A., Doncel G.F. (2001)

Effects of long-term in vitro incubation of human spermatozoa: functional parameters and catalase effect.

Andrologia, 33, 79-86

Calvete J.J., Ensslin M., Mburu J., Iborra A., Martinez P., Adermann K., Waberski D., Sanz L., et al. (1997)

Monoclonal antibodies against boar sperm zona pellucida-binding protein AWN-1. Characterization of a continuous antigenic determinant and immunolocalization of AWN epitopes in inseminated sows.

Biol Reprod, 57, 735-742 
Canvin A.T., Buhr M.M. (1989a)

Effect of temperature on the fluidity of boar sperm membranes.

J Reprod Fertil, 도, 533-540

Canvin A.T., Buhr M.M. (1989b)

Effect of temperature on the fluidity of boar sperm membranes.

J Reprod Fertil, 도, 533-540

Carvajal G., Cuello C., Ruiz M., Vazquez J.M., Martinez E.A., Roca J. (2004)

Effects of centrifugation before freezing on boar sperm cryosurvival.

J Androl, 25, 389-396

Castaneda Moreno J., Becerril Angeles J., Valencia Mendez J. (1996)

Effect of the addition of progesterone to boar semen before freezing or after thawing on fertility, acrosome morphology and sperm motility.

Veterinaria Mexico, 27, 11-16

Catt S.L., Sakkas D., Bizzaro D., Bianchi P.G., Maxwell W.M., Evans G. (1997)

Hoechst staining and exposure to UV laser during flow cytometric sorting does not affect the frequency of detected endogenous DNA nicks in abnormal and normal human spermatozoa.

Mol Hum Reprod, 3 , 821-825

Cerolini S., Maldjian A., Pizzi F., Gliozzi T.M. (2001)

Changes in sperm quality and lipid composition during cryopreservation of boar semen.

Reproduction, 121, 395-401

Cerolini S., Maldjian A., Surai P., Noble R. (2000)

Viability, susceptibility to peroxidation and fatty acid composition of boar semen during liquid storage.

Anim Reprod Sci, 58, 99-111

Chandler D.E., Williams J.A. (1978a)

Intracellular divalent cation release in pancreatic acinar cells during stimulussecretion coupling. I. Use of chlorotetracycline as fluorescent probe.

J Cell Biol, 76, 371-385

Chandler D.E., Williams J.A. (1978b)

Intracellular divalent cation release in pancreatic acinar cells during stimulussecretion coupling. II. Subcellular localization of the fluorescent probe chlorotetracycline.

J Cell Biol, 76, 386-399

Chang M.C. (1951)

Fertilizing capacity of spermatozoa deposited into the fallopian tubes.

Nature, 168, 697-698 
Chang M.C. (1957)

A detrimental effect of seminal plasma on the fertilizing capacity of sperm.

Nature, $179,258-259$

Chatterjee S., De Lamirande E., Gagnon C. (2001)

Cryopreservation alters membrane sulfhydryl status of bull spermatozoa: protection by oxidized glutathione.

Mol.Reprod.Dev., 60, 498

Chatterjee S., Gagnon C. (2001a)

Production of reactive oxygen species by spermatozoa undergoing cooling, freezing, and thawing.

Mol.Reprod.Dev., 59, 451

Chatterjee S., Gagnon C. (2001b)

Production of reactive oxygen species by spermatozoa undergoing cooling, freezing, and thawing.

Mol Reprod Dev, 59, 451-458

Check M.L., Check J.H. (1991)

Poor hypo-osmotic swelling test results from cryopreserved sperm despite preservation of sperm motility.

Arch Androl, 26, 37-41

Cheng F.P., Fazeli A., Voorhout W.F., Marks A., Bevers M.M., Colenbrander B. (1996)

Use of peanut agglutinin to assess the acrosomal status and the zona pellucidainduced acrosome reaction in stallion spermatozoa.

J Androl, 17, 674-682

Cheng F.P., Gadella B.M., Voorhout W.F., Fazeli A., Bevers M.M., Colenbrander B. (1998)

Progesterone-induced acrosome reaction in stallion spermatozoa is mediated by a plasma membrane progesterone receptor.

Biol Reprod, 59, 733-742

Cho C., Jung-Ha H., Willis W.D., Goulding E.H., Stein P., Xu Z., Schultz R.M., Hecht N.B., et al. (2003)

Protamine 2 deficiency leads to sperm DNA damage and embryo death in mice.

Biol Reprod, 69, 211-217

Clarke R.N., Johnson L.A. (1987)

Effect of liquid storage and cryopreservation of boar spermatozoa on acrosomal integrity and the penetration of zona-free hamster ova in vitro.

Gamete Res, 16, 193-204

Claus R. (1990)

Physiological role of seminal components in the reproductive tract of the female pig. J Reprod Fertil Suppl, 40, 117-131 
Claus R., Hoang-Vu C., Ellendorff F., Meyer H.D., Gimenez T. (1988)

Effect of boar seminal oestrogens on uterine contractions and prostaglandin release in the sow.

11th Intern Congr Anim Reprod and AI. Dublin, Vol II, p. 17,

Comaschi V., Lindner L., Farruggia G., Gesmundo N., Colombi L., Masotti L. (1989)

An investigation on lipoperoxidation mechanisms in boar spermatozoa.

Biochem Biophys Res Commun, 158, 769-775

Corcuera B.D., Marigorta P., Sagues A., Saiz-Cidoncha F., Perez-Gutierrez J.F. (2007)

Effect of lactose and glycerol on the motility, normal apical ridge, chromatin condensation and chromatin stability of frozen boar spermatozoa.

Theriogenology, 67, 1150-1157

Cordova A., Perez-Gutierre J.F., Lleo B., Garcia-Artiga C., Alvarez A., Drobchak V., Martin-Rillo S. (2002)

In vitro fertilizing capacity and chromatin condensation of deep frozen boar semen packaged in 0.5 and $5 \mathrm{ml}$ straws.

Theriogenology, 57, 2119-2128

Cordova A., Perez J.F., Lleo B., Garcia Artiga C., Martin Rillo S. (2001)

In vitro fertilizing capacity of deep frozen boar semen packaged in 0.5 and $5 \mathrm{ml}$ straws.

Reprod Dom. Anim, 36, 199-202

Cormier N., Sirard M.A., Bailey J.L. (1997)

Premature capacitation of bovine spermatozoa is initiated by cryopreservation.

J Androl, 18, 461-468

Crabo B. (1991)

Preservation of boar semen: a worldwide perspective. IN Johnson L.A. \& Rath D. (Eds.) Boar Semen Preservation II. Beltsville, MD, USA, Paul Parey, Scientific

Publishers, Berlin and Hamburg.

Reprod. Dom. Anim., Suppl. 1

Crabo B.G., Dial G.D. (1992)

Artificial insemination in swine.

Vet Clin North Am Food Anim Pract, $\underline{8}, 533-544$

Cui K.H. (1997)

Size differences between human $\mathrm{X}$ and $\mathrm{Y}$ spermatozoa and prefertilization diagnosis. Mol Hum Reprod, 3, 61-67

Cui K.H., Matthews C.D. (1993)

$\mathrm{X}$ larger than $\mathrm{Y}$.

Nature, $\underline{366}, 117-118$ 
Cummins J.M., Jequier A.M., Kan R. (1994)

Molecular biology of human male infertility: links with aging, mitochondrial genetics, and oxidative stress?

Mol Reprod Dev, 37, 345-362

Curnock R.M., Reed H.C.B. (1985)

Fertility results from exported boar semen deep frozen by the BF5 method. IN Johnson L.A. \& Larsson K. (Eds.) Deep freezing of boar semen. Uppsala, Sweden, Swedish University of Agricultural Sciences.

Dalvit G.C., Cetica P.D., Beconi M.T. (1998)

Effect of alpha-tocopherol and ascorbic acid on bovine in vitro fertilization.

Theriogenology, 49, 619

Davis B.K. (1981)

Timing of fertilization in mammals: sperm cholesterol/phospholipids ratio as determinants of the capacitation interval.

Proc Natl Acad Sci (USA), 77, 1546-1550

De Alba C., Corcuera B., Conde P., Higuera M.A., Ruvalcaba J.A., HernandezGil R., Lleo B. (2003)

Results with frozen boar semen using different AI techniques.

Theriogenology, 63, 425 Abstract

De Lamirande E., Gagnon C. (1992a)

Reactive oxygen species and human spermatozoa. I. Effects on the motility of intact spermatozoa and on sperm axonemes.

J Androl, 13, 368

De Lamirande E., Gagnon C. (1992b)

Reactive oxygen species and human spermatozoa. II. Depletion of adenosine triphosphate plays an important role in the inhibition of sperm motility.

J Androl, 13, 379-386

De Lamirande E., Gagnon C. (1998)

Paradoxical effect of reagents for sulfhydryl and disulfide groups on human sperm capacitation and superoxide production.

Free Radic.Biol.Med., 25, 803

De Lamirande E., Jiang H., Zini A., Kodama H., Gagnon C. (1997)

Reactive oxygen species and sperm physiology.

Rev Reprod, 2, 48-54

De Leeuw F.E., Colenbrander B., Verkleij A.J. (1991)

The role membrane damage plays in cold shock and freezing injury.

IN: Johnson L.A. \& Rath D. (Eds.) Boar semen Preservation II. Proceedings of the 2nd International Congress on boar semen preservation. Beltsville, Reprod. Dom.

Anim. Suppl. 1, 95-104, 95-104 
De Vries K.J., Wiedmer T., Sims P.J., Gadella B.M. (2003)

Caspase-independent exposure of aminophospholipids and tyrosine phosphorylation in bicarbonate responsive human sperm cells.

Biol Reprod, 68, 2122-2134

Dobrinski I., Smith T.T., Suarez S.S., Ball B.A. (1997)

Membrane contact with oviductal epithelium modulates the intracellular calcium concentration of equine spermatozoa in vitro.

Biol Reprod, 56, 861-869

Donoghue A.M., Garner D.L., Donoghue D.J., Johnson L.A. (1995)

Viability assessment of turkey sperm using fluorescent staining and flow cytometry. Poult Sci, 74, 1191-1200

Dooher G.B., Bennett D. (1973)

Fine structural observations on the development of the sperm head in the mouse. Am J Anat, 136, 339-361

Doyle S.P., Seidel G.E., Jr., Schenk J.L., Herickhoff L.A., Cran D.G., Green R.D. (1999)

Artificial insemination of lactating Angus cows with sexed semen.

Proceedings Western Section, American Society of Animal Science, 50, 203-205

Drummen G.P., Gadella B.M., Post J.A., Brouwers J.F. (2004)

Mass spectrometric characterization of the oxidation of the fluorescent lipid peroxidation reporter molecule C11-BODIPY(581/591).

Free Radic Biol Med, 36, 1635-1644

Dukelow W.R., Chernoff H.N., Williams W.L. (1967)

Properties of decapacitation factor and presence in various species.

J Reprod Fertil, 14, 393-399

Dukelow W.R., Graham E.F. (1962)

Freezing of porcine semen.

J Anim Sci, 21, 1020-1021

Duty S.M., Singh N.P., Ryan L., Chen Z., Lewis C., Huang T., Hauser R. (2002)

Reliability of the comet assay in cryopreserved human sperm.

Hum Reprod, 17, 1274-1280

Engelhardt H., Croy B.A., King G.J. (1997)

Role of uterine immune cells in early pregnancy in pigs.

J Reprod Fertil Suppl, 52, 115-131

Ericsson R.J., Langevin C.N., Nishino M. (1973)

Isolation of fractions rich in human Y sperm.

Nature, 246, 421-424 
Eriksson B., Rodriguez-Martinez H. (2000a)

Export of frozen boar semen in a new flat package. IN Johnson L.A. \& Guthrie H.D. (Eds.) Boar semen preservation IV. Beltsville, USA.

Reprod. Dom. Anim., $\underline{31}$, Suppl. 1

Eriksson B.M., Petersson H., Rodriguez-Martinez H. (2002)

Field fertility with exported boar semen frozen in the new FlatPack container.

Theriogenology, 58, 1065-1079

Eriksson B.M., Rodriguez-Martinez H. (2000b)

Deep-freezing of boar semen in plastic film 'cochettes'.

$J$ Vet Med. Series A, 47, 89-97

Eriksson B.M., Rodriguez-Martinez H. (2000c)

Deep-freezing of boar semen in plastic film 'cochettes'.

Zentralbl Veterinarmed A, 47, 89-97

Eriksson B.M., Rodriguez-Martinez H. (2000d)

Effect of freezing and thawing rates on the post-thaw viability of boar spermatozoa frozen in FlatPacks and Maxi-straws.

Anim Reprod Sci, 63, 205-220

Eriksson B.M., Vazquez J.M., Martinez E.A., Roca J., Lucas X., RodriguezMartinez H. (2001)

Effects of holding time during cooling and of type of package on plasma membrane integrity, motility and in vitro oocyte penetration ability of frozen-thawed boar spermatozoa.

Theriogenology, 55, 1593-1605

Evenson D., Jost L. (2000)

Sperm chromatin structure assay is useful for fertility assessment.

Methods Cell Sci, 22, 169-189

Fazeli A., Duncan A.E., Watson P.F., Holt W.V. (1999)

Sperm-oviduct interaction: induction of capacitation and preferential binding of uncapacitated spermatozoa to oviductal epithelial cells in porcine species.

Biol Reprod, 60, 879-886

Fazeli A., Hage W.J., Cheng F.P., Voorhout W.F., Marks A., Bevers M.M., Colenbrander B. (1997)

Acrosome-intact boar spermatozoa initiate binding to the homologous zona pellucida in vitro.

Biol Reprod, 56, 430-438

Fazeli A.R., Holt C., Steenweg W., Bevers M.M., Holt W.V., Colenbrander B. (1995)

Development of a sperm Hemizona binding assay for boar semen.

Theriogenology, $\underline{44}, 17$ 
Fiser P.S., Fairfull R.W. (1990)

Combined effect of glycerol concentration and cooling velocity on motility and acrosomal integrity of boar spermatozoa frozen in $0.5 \mathrm{ml}$ straws.

Mol Reprod Dev, 25, 123-129

Fiser P.S., Fairfull R.W., Hansen C., Panich P.L., Shrestha J.N., Underhill L. (1993)

The effect of warming velocity on motility and acrosomal integrity of boar sperm as influenced by the rate of freezing and glycerol level.

Mol Reprod Dev, 34, 190-195

Fiser P.S., Hansen C., Underhill L., Marcus G.J. (1991)

New thermal stress test to assess the viability of cryopreserved boar sperm.

Cryobiology, 28, 454-459

Flesch F.M., Voorhout W.F., Colenbrander B., Van Golde L.M., Gadella B.M. (1998)

Use of lectins to characterize plasma membrane preparations from boar spermatozoa: a novel technique for monitoring membrane purity and quantity.

Biol Reprod, 59, 1530-1539

Florman H.M. (1994)

Sequential focal and global elevations of sperm intracellular $\mathrm{Ca} 2+$ are initiated by the zona pellucida during acrosomal exocytosis.

Dev Biol, $\underline{165}$, 152-164

Florman H.M., Arnoult C., Kazam I.G., Li C., O'toole C.M. (1998)

A perspective on the control of mammalian fertilization by egg-activated ion channels in sperm: a tale of two channels.

Biol Reprod, 59, 12-16

Flowers W.L., Esbenhade K.L. (1993)

Optimizing management of natural and artificial matings in swine.

J Reprod Fertil Suppl, 48, 217-228

Foote R.H. (1967)

Factors prolonging survival of unfrozen bovine spermatozoa.

J Dairy Sci, 50, 1338-1340

Foote R.H., Brockett C.C., Kaproth M.T. (2002)

Motility and fertility of bull sperm in whole milk extender containing antioxidants.

Anim Reprod.Sci, 71, 13

Fraser L., Dziekonska A., Strzezek R., Strzezek J. (2007)

Dialysis of boar semen prior to freezing-thawing: Its effects on post-thaw sperm characteristics.

Theriogenology, 67, 994-1003 
Fraser L., Strzezek J. (2005)

Effects of freezing-thawing on DNA integrity of boar spermatozoa assessed by the neutral comet assay.

Reprod Dom. Anim, 40, 530-536

Fraser L.R., Ahuja K.K. (1988)

Metabolic and surface events in fertilization.

Gamete Res, 20, 491-519

Fraser L.R., Harrison R.A., Herod J.E. (1990)

Characterization of a decapacitation factor associated with epididymal mouse spermatozoa.

J Reprod Fertil, 오, 135-148

Gadea J. (2005)

Sperm factors related to in vitro and in vivo porcine fertility.

Theriogenology, $\underline{63}, 431$

Gadea J., Gumbao D., Matas C., Romar R. (2005)

Supplementation of the thawing media with reduced glutathione improves function and the in vitro fertilizing ability of boar spermatozoa after cryopreservation.

J Androl, 26, 749-756

Gadella B.M., Flesch F.M., Van Golde L.M., Colenbrander B. (1999a)

Dynamics in the membrane organization of the mammalian sperm cell and functionality in fertilization.

Vet $Q, \underline{21}, 142-146$

\section{Gadella B.M., Harrison R.A. (2000)}

The capacitating agent bicarbonate induces protein kinase A-dependent changes in phospholipid transbilayer behavior in the sperm plasma membrane.

Development, 127, 2407

\section{Gadella B.M., Harrison R.A. (2002)}

Capacitation induces cyclic adenosine 3',5'-monophosphate-dependent, but apoptosis-unrelated, exposure of aminophospholipids at the apical head plasma membrane of boar sperm cells.

Biol.Reprod., 67, 340-350

\section{Gadella B.M., Miller N.G., Colenbrander B., Van Golde L.M., Harrison R.A. (1999b)}

Flow cytometric detection of transbilayer movement of fluorescent phospholipid analogues across the boar sperm plasma membrane: elimination of labeling artifacts. Mol Reprod Dev, 53, 108-125

Garner D.L. (2006)

Flow cytometric sexing of mammalian sperm.

Theriogenology, 65, 943-957 
Garner D.L., Hafez E.S.E. (2000)

Spermatozoa and Seminal Plasma.

IN: Hafez E.S.E. \& Hafez B. (Eds.) Reproduction in Farm Animals (7th Edition). Philadelphia, Baltimore, New York, London, Buenos Aires, Hong Kong, Sydney,

Tokyo, Lippincott Williams \& Wilkins, 96-109

Garner D.L., Johnson L.A. (1995)

Viability assessment of mammalian sperm using SYBR-14 and propidium iodide. Biol Reprod, 53, 276-284

Garner D.L., Johnson L.A., Yue S.T., Roth B.L., Haugland R.P. (1994)

Dual DNA staining assessment of bovine sperm viability using SYBR-14 and propidium iodide.

J Androl, 15, 620-629

Garner D.L., Pinkel D., Johnson L.A., Pace M.M. (1986)

Assessment of spermatozoal function using dual fluorescent staining and flow cytometric analyses.

Biol Reprod, 34, 127-138

Garner D.L., Thomas C.A. (1999)

Organelle-specific probe JC-1 identifies membrane potential differences in the mitochondrial function of bovine sperm.

Mol.Reprod.Dev., 53, 222

Garner D.L., Thomas C.A., Gravance C.G. (1999)

The Effect of Glycerol on the Viability, Mitochondrial Function and Acrosomal Integrity of Bovine Spermatozoa.

Reprod. Dom. Anim., 34, 399-404

Garner D.L., Thomas C.A., Joerg H.W., Dejarnette J.M., Marshall C.E. (1997) Fluorometric assessments of mitochondrial function and viability in cryopreserved bovine spermatozoa.

Biol Reprod, 57, 1401-1406

Geisler A. (1990)

Prüfung von Vitalfärbungen für Spermien von Haussäugetieren.

Dissertation, Fakultät für Veterinärmedizin, Ludwig-Maximilians Universität, München

Gil J., Jimenez M., Diaz C., Sanchez R., Martin Rillo S. (1996)

Swine AI with frozen boar semen in work routine.

Reprod Dom. Anim, 31, 289-290

Gillan L., Evans G., Maxwell W.M. (1997)

Capacitation status and fertility of fresh and frozen-thawed ram spermatozoa.

Reprod Fertil Dev, 9, 481-487 
Gillan L., Evans G., Maxwell W.M.C. (2005)

Flow cytometric evaluation of sperm parameters in relation to fertility potential. Theriogenology, $\underline{63}, 445$

Goolsby H.A., Blanton J.R., Cotter P.Z., Prien S.D. (2004)

Preliminary trial: motility comparisons of a unique freezing technology (UFT) to liquid nitrogen mist methodology for cryopreservation of porcine spermatozoa. Reprod Dom. Anim, 39, 328-332

Green C.E., Bredl J., Holt W.V., Watson P.F., Fazeli A. (2001)

Carbohydrate mediation of boar sperm binding to oviductal epithelial cells in vitro. Reproduction, 122, 305-315

Green C.E., Watson P.F. (2001)

Comparison of the capacitation-like state of cooled boar spermatozoa with true capacitation.

Reproduction, 122, 889-898

Grossfeld R., Klinc P., Sieg B., Rath D. (2005)

Production of piglets with sexed semen employing a non-surgical insemination technique.

Theriogenology, $\underline{63}, 2269$

Guthrie H.D., Welch G.R. (2005)

Impact of storage prior to cryopreservation on plasma membrane function and fertility of boar sperm.

Theriogenology, $\underline{63}$, 396-410

Hadjisavas M., Laurenz J.C., Bazer F.W. (1994)

Seminal plasma (SPL): a potential mediator of inflammation in the uterus following mating in the pig.

Biol Reprod Suppl, 50, 76 (Abstract)

Halliwell B., Aruoma O.I. (1991)

DNA damage by oxygen-derived species. Its mechanism and measurement in mammalian systems.

FEBS Lett, 281, 9-19

Halliwell B., Gutteridge J.M. (1984)

Lipid peroxidation, oxygen radicals, cell damage, and antioxidant therapy.

Lancet, 1, 1396-1397

Hammerstedt R.H., Graham J.K., Nolan J.P. (1990)

Cryopreservation of mammalian sperm: what we ask them to survive.

J Androl, 11, 73-88 
Hammit D.G., Martin P.A. (1989)

Fertility of frozen-thawed porcine semen following controlled-rate freezing in straws.

Theriogenology, 32, 359-368

Hammitt D.G., Martin P.A., Callanan T. (1989)

Correlations between heterospermic fertility and assays of porcine semen quality before and after cryopreservation.

Theriogenology, 32, 385-399

Harrison R.A. (1997)

Sperm plasma membrane characteristics and boar semen fertility.

J Reprod Fertil Suppl, 52, 195-211

Harrison R.A., Ashworth P.J., Miller N.G. (1996)

Bicarbonate/CO2, an effector of capacitation, induces a rapid and reversible change in the lipid architecture of boar sperm plasma membranes.

Mol.Reprod.Dev., 45, 378

Harrison R.A., Mairet B., Miller N.G. (1993)

Flow cytometric studies of bicarbonate mediates Ca2+ Influx in boar sperm populations.

Mol Reprod Dev, 35, 197-218

Harrison R.A., White I.G. (1972)

Glycolytic enzymes in the spermatozoa and cytoplasmic droplets of bull, boar and ram, and their leakage afte shock.

J Reprod Fertil, 30, 105-115

Haugland R.P. (2004)

Assays for cell viability, proliferation and function.

Handbook of fluorescent probes and research products. 9 ed., Eugene: Molecular

Probes Inc.

Hendriksen P.J. (1999)

Do $\mathrm{X}$ and $\mathrm{Y}$ spermatozoa differ in proteins?

Theriogenology, 52, 1295-1307

Hendriksen P.J., Welch G.R., Grootegoed J.A., Van Der Lende T., Johnson L.A. (1996)

Comparison of detergent-solubilized membrane and soluble proteins from flow cytometrically sorted X-and Y-chromosome bearing porcine spermatozoa by high resolution 2-D electrophoresis.

Mol Reprod Dev, 45, 342-350

Herr C.M., Holt N.A., Matthaei K.I., Reed K.C. (1990)

Sex of progeny from bovine embryos sexed with a rapid $\mathrm{Y}$-chromosome-detection assay.

Theriogenology, $\underline{33}, 247$ 
Hess E.A., Ludwick T.M., Teague H.S. (1960)

Motility of boar spermatozoa as influenced by semen freezing procedure.

J Anim Sci, 19, 926-931

Hinkovska-Galcheva V., Petkova D., Koumanov K. (1989)

Changes in the phospholipid composition and phospholipid asymmetry of ram sperm plasma membranes after cryopreservation.

Cryobiology, 26, 70-75

Hinshaw D.B., Sklar L.A., Bohl B., Schraufstatter I.U., Hyslop P.A., Rossi M.W., Spragg R.G., Cochrane C.G. (1986)

Cytoskeletal and morphologic impact of cellular oxidant injury.

Am J Pathol, 123, 454-464

Hoffmann H.H. (1959)

Versuche zur Frostkonservierung des Ebersamens.

Dissertation, Tierärztliche Hochschule München, München

Hofmo P.O. (1991)

Commercial swine AI with liquid semen in Norway.

IN: Johnson L.A. \& Rath D. (Eds.) Boar Semen Preservation II. Berlin, Paul Parey, Scientific Publishers, 317-320

Reprod. Dom. Anim., Suppl. 1

Hofmo P.O., Grevle I.S. (2000)

Development and commercial use of frozen boar semen in Norway. IN Guthrie L.A.J.A.H.D. (Ed.) Boar semen preservation IV. Allen Press, Lawrence, KS.

Reprod. Dom Anim., $\underline{31}$, Suppl. 1

Holden C.A., Hyne R.V., Sathananthan A.H., Trounson A.O. (1990)

Assessment of the human sperm acrosome reaction using concanavalin A lectin.

Mol Reprod Dev, 25, 247-257

Hollinshead F.K., Gillan L., O'brien J.K., Evans G., Maxwell W.M. (2003)

In vitro and in vivo assessment of functional capacity of flow cytometrically sorted ram spermatozoa after freezing and thawing.

Reprod Fertil Dev, 15, 351-359

Holt C., Holt W.V., Moore H.D., Reed H.C., Curnock R.M. (1997)

Objectively measured boar sperm motility parameters correlate with the outcomes of on-farm inseminations: results of two fertility trials.

J Androl, 18, 312-323

Holt W.V., Medrano A., Thurston L.M., Watson P.F. (2005)

The significance of cooling rates and animal variability for boar sperm cryopreservation: insights from the cryomicroscope.

Theriogenology, 63, 370-382 
Holt W.V., North R.D. (1994)

Effects of temperature and restoration of osmotic equilibrium during thawing on the induction of plasma membrane damage in cryopreserved ram spermatozoa.

Biol Reprod, 51, 414-424

Hong C.Y., Huang J.J., Wu P., Lo S.J., Wei Y.H. (1988)

Fluorescence supravital stain of human sperm: correlation with sperm motility measured by a transmembrane migration method.

Andrologia, 20, 516-520

Hunter R.H., Flechon B., Flechon J.E. (1987)

Pre- and peri-ovulatory distribution of viable spermatozoa in the pig oviduct: a scanning electron microscope study.

Tissue Cell, 19, 423-436

Hunter R.H.F. (1988)

The Fallopian Tubes. Their Role in Fertility and Infertility., Berlin, Heidelberg, Springer-Verlag.

Hunter R.H.F. (1995)

Ovarian endocrine control of sperm progression in the fallopian tubes.

Oxf Rev Reprod Biol, 17, 85-124

Hunter R.H.F., Greve T. (1998)

Deep intrauterine insemination of cattle: a fruitful way forward with smaller numbers of spermatozoa.

Act Vet Scand, 39, 149-163

Ichikawa T., Oeda T., Ohmori H., Schill W.B. (1999)

Reactive oxygen species influence the acrosome reaction but not acrosin activity in human spermatozoa.

Int.J Androl, 22, 37

Ivanova M., Mollova M. (1993)

Zona-penetration in vitro test for evaluating boar sperm fertility.

Theriogenology, 40, 397-410

Iwamoto T., Tsang A., Luterman M., Dickson J., De Lamirande E., Okuno M., Mohri H., Gagnon C. (1992)

Purification and characterization of a sperm motility-dynein ATPase inhibitor from boar seminal plasma.

Mol Reprod Dev, 31, 55-62

Jeyendran R.S., Van Der Ven H.H., Perez-Pelaez M., Crabo B.G., Zaneveld L.J. (1984)

Development of an assay to assess the functional integrity of the human sperm membrane and its relationship to other semen characteristics.

J Reprod Fertil, 70, 219-228 
Jeyendran R.S., Van Der Ven H.H., Zaneveld L.J. (1992)

The hypoosmotic swelling test: an update.

Arch Androl, 29, 105-116

Jiang Z.L., Li Q.W., Li W.Y., Hu J.H., Zhao H.W., Zhang S.S. (2006)

Effect of low density lipoprotein on DNA integrity of freezing-thawing boar sperm by neutral comet assay.

Anim Reprod Sci, in press

\section{Jimenez I., Gonzalez-Marquez H., Ortiz R., Betancourt M., Herrera J., Fierro} R. (2002)

Expression of lectin receptors on the membrane surface of sperm of fertile and subfertile boars by flow cytometry.

Arch Androl, 48, 159-166

Johnson L.A. (1985)

Fertility results using frozen boar spermatozoa.

1st. Int. Conf. on Deep Freezing of Boar Semen. Uppsala, 199-222

Johnson L.A. (1991)

Sex preselection in swine: altered sex ratios in offspring following surgical insemination of flow sorted X-and Y-bearing sperm.

Reprod Dom. Anim, 26, 309-314

Johnson L.A. (2000)

Sexing mammalian sperm for production of offspring: the state-of-the-art.

Anim Reprod Sci, 60-61, 93-107

Johnson L.A., Aalbers J.G., Willems C.M., Sybesma W. (1981)

Use of spermatozoa for artificial insemination. I. Fertilizing capacity of fresh and frozen spermatozoa in sows on 36 farms.

J Anim Sci, 2, 1130-1136

Johnson L.A., Clarke R.N. (1988)

Flow sorting of $\mathrm{X}$ and $\mathrm{Y}$ chromosome-bearing mammalian sperm: activation and pronuclear development of sorted bull, boar, and ram sperm microinjected into hamster oocytes.

Gamete Res, 21, 335-343

Johnson L.A., Flook J.P., Hawk H.W. (1989)

Sex preselection in rabbits: live births from $\mathrm{X}$ and $\mathrm{Y}$ sperm separated by DNA and cell sorting.

Biol Reprod, 41, 199-203

Johnson L.A., Flook J.P., Look M.V., Pinkel D. (1987)

Flow sorting of $\mathrm{X}$ and $\mathrm{Y}$ chromosome-bearing spermatozoa into two populations.

Gamete Res, 16, 1-9 
Johnson L.A., Guthrie H.D., Fiser P., Maxwell W.M., Welch G., Garett W.M. (2000)

Cryopreservation of flowcytometrically sorted boar sperm: Effects on in vivo embryo development.

J Anim Sci, 78 (Suppl. 1), 198

Johnson L.A., Rath D., Vazquez J.M., Maxwell W.M., Dobrinsky J.R. (2005a)

Preselection of sex of offspring in swine for production: current status of the process and its application.

Theriogenology, 63, 615-624

Johnson L.A., Rath D., Vazquez J.M., Maxwell W.M.C., Dobrinsky J.R. (2005b) Preselection of sex of offspring in swine for production: current status of the process and its application.

Theriogenology, 63, 615-624

Johnson L.A., Welch G.R. (1999)

Sex preselection: high-speed flow cytometric sorting of $\mathrm{X}$ and $\mathrm{Y}$ sperm for maximum efficiency.

Theriogenology, 52, 1323-1341

Kaneko S., Oshio S., Kobayashi T., Iizuka R., Mohri H. (1984)

Human X-and Y-bearing sperm differ in cell surface sialic acid content.

Biochem Biophys Res Commun, 124, 950-955

Kaneto M., Harayama H., Miyake M., Kato S. (2002)

Capacitation-like alterations in cooled boar spermatozoa: assessment by the chlortetracycline staining assay and immunodetection of tyrosine-phosphorylated sperm proteins.

Anim Reprod Sci, 73, 197-209

Kasai T., Ogawa K., Mizuno K., Nagai S., Uchida Y., Ohta S., Fujie M., Suzuki K., et al. (2002)

Relationship between sperm mitochondrial membrane potential, sperm motility, and fertility potential.

Asian J Androl, 4, 97-103

Kawarasaki T., Welch G.R., Long C.R., Yoshida M., Johnson L.A. (1998)

Verification of flow cytometorically-sorted $\mathrm{X}$ - and $\mathrm{Y}$-bearing porcine spermatozoa and reanalysis of spermatozoa for DNA content using the fluorescence in situ hybridization (FISH) technique.

Theriogenology, 50, 625-635

Kemp B., Soede N.M. (1997)

Consequences of variation in interval from insemination to ovulation on fertilization in pigs.

J Reprod Fertil Suppl, 52, 79-89 
Kikuchi K., Kashiwazaki N., Nagai T., Noguchi J., Shimada A., Takahashi R., Hirabayashi M., Shino M., et al. (1999)

Reproduction in pigs using frozen-thawed spermatozoa from epididymis stored at $4 \mathrm{C}$.

J. Reprod. Dev., 45, 345-350

Kikuchi K., Nagai T., Kashiwazaki N., Ikeda H., Noguchi J., Shimada A., Soloy E., Kaneko H. (1998)

Cryopreservation and ensuing in vitro fertilization ability of boar spermatozoa from epididymides stored at 4 degrees $\mathrm{C}$.

Theriogenology, 50, 615-623

King G.J., Macpherson J.W. (1966)

Boar semen studies. I. Laboratory evaluation of processing phases.

Can J Comp Med, $\underline{30,} 12$

Kirchhoff C. (1995)

Molecular biology of sperm maturation in the human epididymis.

Reprod Med Rev, 4, 121-139

Klinc P. (2005)

Improved fertility of flowcytometrically sex sorted bull spermatozoa.

Dissertation, Tierärztliche Hochschule, Hannover

Klinc P., Frese D., Osmers H., Rath D. (2007)

Insemination with sex sorted fresh bovine spermatozoa processed in the presence of antioxidative substances.

Reprod Dom. Anim, 42, 58-62

Klinc P., Rath D. (2007)

Reduction of oxidative stress in bovine spermatozoa during flow cytometric sorting. Reprod Dom. Anim, 42, 63-67

Knöppel S. (2001)

Lektinbindungsvermögen von gesextem und ungesextem sperma.

Diplomarbeit, GHS Paderborn, Fachbereich Agrarwirtschaft Soest, Soest

Koch E., Ellendorff F. (1985)

Detection of activity similar to that of early pregnancy factor after mating sows with a vasectomized boar.

J Reprod Fertil, 74, 39-46

Kodama H., Kuribayashi Y., Gagnon C. (1996)

Effect of sperm lipid peroxidation on fertilization.

J Androl, 17, 151 
Kojima Y., Iida I., Bamba K., Kobayashi S. (1967)

Studies on deep freezing of boar semen. Additional effects of DMSO as a cryoprotective agent.

Jap J Anim Reprod, 13, 149-155

Koolman J., Röhm K.H. (1994)

Taschenatlas der Biochemie.

Stuttgart, Georg Thieme Verlag, 200-214

Kotzias-Bandeira E., Waberski D., Weitze K.F. (1997)

[Cooling of boar spermatozoa prior to freezing and post thaw quality and evaluation of membrane state using chlortetracycline (CTC) staining].

Dtsch Tierarztl Wochenschr, 104, 302-306

Kozumplik J. (1985)

[Qualitative changes and the fertilizing capacity of sperm after 6 years of preservation of boar semen].

Vet Med (Praha) JT - Veterinarni medicina., 30, 289

Krause D. (1966)

Untersuchungen am Bullensperma unter Berücksichtigung der

fertilitätsdiagnostischen Bedeutung der Befunde.

Habil-Schr., Tierärztliche Hochschule, Hannover

Krausz C., West K., Buckingham D., Aitken R.J. (1992)

Development of a technique for monitoring the contamination of human semen samples with leukocytes.

Fertil Steril, 57, 1317-1325

Krienke M. (2003)

Evaluierung durchflusszytometrischer Verfahren zur Beurteilung der Qualität von kryokonserviertem Hengstsperma.

Dissertation, Tierärztliche Fakültät, Ludwig-Maximilians-Universität, München

Krueger C., Rath D., Johnson L.A. (1999)

Low dose insemination in synchronized gilts.

Theriogenology, 52, 1363-1373

Kumar S., Millar J.D., Watson P.F. (2003)

The effect of cooling rate on the survival of cryopreserved bull, ram, and boar spermatozoa: a comparison of two controlled-rate cooling machines.

Cryobiology, $\underline{46}, 246-253$

Kumi-Diaka J., Badtram G. (1994)

Effect of storage on sperm membrane integrity and other functional characteristics of canine spermatozoa: In vitro bioassay for canine semen.

Theriogenology, 41, 1355-1366 
Kuo Y.H., Chiang J.C. (1990)

The fertility of frozen thawed boar semen prepared in macrotubes. Boar semen preservation II,. Beltsville, USA.

Reprod. Dom. Anim., Suppl. 1

Kuo Y.H., Huang S.Y. (2000)

Effects of different extenders on post-thaw sperm motility and fertility in frozen boar semen. IN Johnson L.A. \& Guthrie H.D. (Eds.) Boar semen preservation IV.

Beltsville, USA.

Reprod. Dom. Anim., $\underline{31}$, Suppl. 1

Langner M., Hui S.W. (1993)

Merocyanine interaction with phosphatidylcholine bilayers.

Biochim Biophys Acta, 1149, 175-179

Leclerc P., De Lamirande E., Gagnon C. (1997)

Regulation of protein-tyrosine phosphorylation and human sperm capacitation by reactive oxygen derivatives.

Free Radic Biol Med, 22, 643-656

Lee M.A., Trucco G.S., Bechtol K.B., Wummer N., Kopf G.S., Blasco L., Storey B.T. (1987)

Capacitation and acrosome reactions in human spermatozoa monitored by a chlortetracycline fluorescence assay.

Fertil Steril, $\underline{48,649-658}$

Lehninger A.L., Nelson D.L., Cox M.M. (1994)

Prinzipien der Biochemie.

Heidelberg, Berlin, Oxford, Spektrum Akademischer Verlag, 33-344

Leonhardt H. (1990)

Histologie, Zytologie und Mikroanatomie des Menschen, Taschenlehrbuch der gesamten Anatomie, Band III. Georg Thieme Verlag, Stuttgart, New York, 484-502

Leshin L.S., Raj S.M., Smith C.K., Kwok S.C., Kraeling R.R., Li W.I. (1998)

Immunostimulatory effects of pig seminal proteins on pig lymphocytes.

J Reprod Fertil, 114, 77-84

Levinson G., Fields R.A., Harton G.L., Palmer F.T., Maddalena A., Fugger E.F., Schulman J.D. (1992)

Reliable gender screening for human preimplantation embryos, using multiple DNA target-sequences.

Hum Reprod, 7, 1304-1313 
Lichtenstern A. (1995)

Färbeverhalten von Bulle-, Schafbock- und Eberspermien vor und nach In-Vitro-

Kapazitation in verschiedenen Medien.

Dissertation, Fakultät für Veterinärmedizin, Ludwig-Maximilians Universität,

München

Linfor J.J., Meyers S.A. (2002)

Detection of DNA damage in response to cooling injury in equine spermatozoa using single-cell gel electrophoresis.

J Androl, 23, 107-113

Long C.R., Dobrinsky J.R., Johnson L.A. (1999)

In vitro production of pig embryos: comparisons of culture media and boars.

Theriogenology, 51, 1375-1390

Lopes S., Jurisicova A., Sun J.G., Casper R.F. (1998)

Reactive oxygene species: potential cause for DNA fragmentation in human spermatozoa.

Hum Reprod, 13, 896-900

Lubart R., Friedmann H., Sinyakov M., Cohen N., Breitbart H. (1997)

Changes in calcium transport in mammalian sperm mitochondria and plasma membranes caused by $780 \mathrm{~nm}$ irridation.

Laser Surg Med, 21, 493-499

Lynham J.A., Harrison R.A. (1998)

Use of stored pig eggs to assess boar sperm fertilizing functions in vitro.

Biol Reprod, 58, 539-550

Maldjian A., Pizzi F., Gliozzi T., Cerolini S., Penny P., Noble R. (2005)

Changes in sperm quality and lipid composition during cryopreservation of boar semen.

Theriogenology, $\underline{63}, 411$

Malmi R., Kallajoki M., Suominen J. (1987)

Distribution of glycoconjugates in human testis. A histochemical study using fluorescein- and rhodamine-conjugated lectins.

Andrologia, 19, 322-332

Mammoto A., Masumoto N., Tahara M., Ikebuchi Y., Ohmichi M., Tasaka K., Miyake A. (1996)

Reactive oxygen species block sperm-egg fusion via oxidation of sperm sulfhydryl proteins in mice.

Biol.Reprod., 55, 1063 
Manicardi G.C., Bianchi P.G., Pantano S., Azzoni P., Bizzaro D., Bianchi U., Sakkas D. (1995)

Presence of endogenous nicks in DNA of ejaculated human spermatozoa and its relationship to chromomycin A3 accessibility.

Biol Reprod, 52, 864-867

Mann T., Lutwack-Mann C. (1981)

Male reproductive function and semen, Berlin, Heidelberg, New-York, SpringerVerlag.

Mantegazza P. (1866)

Sullo sperma umano.

Rc. Inst. lomb. Sci. Lett., 13, 183-196. Cited by Watson P.F. 1979

Martinez E., Vazquez J.M., Matas C., Roca J., Coy P., Gadea J. (1993)

Evaluation of boar spermatozoa penetrating capacity using pig oocytes at the germinal vesicle stage.

Theriogenology, $\underline{40}, 547-557$

Martinez E.A., Vazquez J.M., Roca J., Lucas X., Gil M.A., Parrilla I., Vazquez J.L., Day B.N. (2001)

Successful non-surgical deep intrauterine insemination with small numbers of spermatozoa in sows.

Reproduction, 122, 289-296

Masuda H., Ryouhou M., Jin Z., Kan K., Fujiwara T. (2002)

Effects of magnetic fields on the freezing of boar spermatozoa.

Jap. J. Swine Sci., 39, 175-182

Maxwell W.M., Evans G., Hollinshead F.K., Bathgate R., De Graaf S.P., Eriksson B.M., Gillan L., Morton K.M., et al. (2004)

Integration of sperm sexing technology into the ART toolbox.

Anim Reprod Sci, $\underline{82-83}$, 79-95

Maxwell W.M., Johnson L.A. (1997)

Chlortetracycline analysis of boar spermatozoa after incubation, flow cytometric sorting, cooling, or cryopreservation.

Mol Reprod Dev, 46, 408-418

Maxwell W.M., Long C.R., Johnson L.A., Dobrinsky J.R., Welch G.R. (1998) The relationship between membrane status and fertility of boar spermatozoa after flow cytometric sorting in the presence or absence of seminal plasma.

Reprod Fertil Dev, 10, 433-440

Maxwell W.M., Stojanov T. (1996)

Liquid storage of ram semen in the absence or presence of some antioxidants.

Reprod.Fertil.Dev., 요, 1013 
Maxwell W.M., Welch G.R., Johnson L.A. (1996)

Viability and membrane integrity of spermatozoa after dilution and flow cytometric sorting in the presence or absence of seminal plasma.

Reprod Fertil Dev, $\underline{8}$, 1165-1178

Mazur P. (1984)

Freezing of living cells: mechanisms and implications.

Am J Physiol, 247, C125-142

Mazur P. (1985)

Basic concepts in freezing cells.

1st Int. Conf. on Deep Freezing of Boar Semen. Uppsala, 91-111

Mazur P., Katkov I., Katkova N., Critser J.K. (2000)

The enhancement of the ability of mouse sperm to survive freezing and thawing by use of high concentrations of glycerol and the presence of an Escherichia coli membrane preparation (Oxyrase) to lower the oxygen concentration.

Cryobiology, $\underline{40}$, 187-209

Mburu J.N. (1997)

Sperm distribution in the porcine oviduct in relation to spontaneous ovulation and stress.

Thesis Veterinaria 28, Swedish University of Agricultural Sciences, Uppsala, Mclaughlin E.A., Ford W.C. (1994)

Effects of cryopreservation on the intracellular calcium concentration of human spermatozoa and its response to progesterone.

Mol Reprod Dev, 37, 241-246

Mclaughlin E.A., Ford W.C., Hull M.G. (1992)

Motility characteristics and membrane integrity of cryopreserved human spermatozoa.

J Reprod Fertil, 95, 527-534

Medrano A. (1998)

The importance of individual variation in boar semen cryopreservation.

Ph.D. Thesis, University of London,

Medrano A., Watson P.F., Holt W.V. (2002)

Importance of cooling rate and animal variability for boar sperm cryopreservation: insights from the cryomicroscope.

Reproduction, 123, 315-322

Miller D.J., Demers J.M., Braundmeier A.G., Behrens M.L. (1998)

The use of two fluorescent dyes to identify sperm in a competitive binding assay to oocytes.

J Androl, 19, 650-656 
Mohri H., Yanagimachi R. (1980)

Characteristics of motor apparatus in testicular, epididymal and ejaculated spermatozoa. A study using demembranated sperm models.

Exp Cell Res, 127, 191-196

Montag M., Rink K., Delacretaz G., D. Van V. (2000)

Laser-induced immobilization and plasma membrane permeabilization in human spermatozoa.

Hum Reprod, 15, 846-852

Moore H.D., Hibbitt K.G. (1977)

Fertility of boar spermatozoa after freezing in the absence of seminal vesicular proteins.

J Reprod Fertil, 50, 349-352

Moruzzi J.F. (1979)

Selecting a mammalian species for the separation of $\mathrm{X}$ - and $\mathrm{Y}$-chromosome-bearing spermatozoa.

J Reprod Fertil, 57, 319-323

Muller K., Pomorski T., Muller P., Herrmann A. (1999)

Stability of transbilayer phospholipid asymmetry in viable ram sperm cells after cryotreatment.

J Cell Sci, 112 (Pt 1), 11-20

Nagy S., Jansen J., Topper E.K., Gadella B.M. (2003)

A triple-stain flow cytometric method to assess plasma- and acrosome-membrane integrity of cryopreserved bovine sperm immediately after thawing in presence of egg-yolk particles.

Biol Reprod, 68, 1828-1835

Niemann H., Rath D., Wrenzycki C. (2003)

Advances in biotechnology: new tools in future pig production for agriculture and biomedicine.

Reprod Dom. Anim, 38, 82-89

Nizanski W., Bielas W. (2003)

Comparison of the effect of consecutive stages of cryopreservation on spermatozoal properties in dogs and boars and preliminary results of artificial insemination with frozen-thawed semen.

Medycyna Weterynaryjna, 59, 898-904

Noiles E.E., Bailey J.L., Storey B.T. (1995)

The temperature dependence in the hydraulic conductivity, Lp, of the mouse sperm plasma membrane shows a discontinuity between 4 and 0 degrees $\mathrm{C}$.

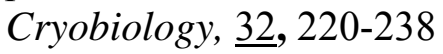


Noiles E.E., Mazur P., Watson P.F., Kleinhans F.W., Critser J.K. (1993)

Determination of water permeability coefficient for human spermatozoa and its activation energy.

Biol Reprod, 48, 99-109

O'flaherty C., Beconi M., Beorlegui N. (1997)

Effect of natural antioxidants, superoxide dismutase and hydrogen peroxide on capacitation of frozen-thawed bull spermatozoa.

Andrologia, 29, 269-275

Oehninger S., Blackmore P., Mahony M., Hodgen G. (1995)

Effects of hydrogen peroxide on human spermatozoa.

J Assist.Reprod.Genet., 12, 41

Ollero M., Blanco T.M., Lopez-Perez M.J., Cebrian Perez J.A. (1996)

Surface changes associated with ram sperm cryopreservation revealed by countercurrent distribution in an aqueous two-phase system. Effect of different cryoprotectants.

J Chromatogr B Biomed Appl, $\underline{680}$, 157-164

Parilla I., Vazquez J.M., Centurion F., Roca J., Gil M.A., Lucas X., Martinez E.A. (2001)

Effect of high-speed flow sorting on sperm motility pattern of boar sperm.

Theriogenology, 55, 501

Park N.C., Park H.J., Lee K.M., Shin D.G. (2003)

Free radical scavenger effect of rebamipide in sperm processing and cryopreservation.

Asian J Androl, 5, 195-201

Parks J.E., Graham J.K. (1992a)

Effects of cryopreservation procedures on sperm membranes.

Theriogenology, 38, 209-222

Parks J.E., Graham J.K. (1992b)

Effects of cryopreservation procedures on sperm membranes.

Theriogenology, 38, 209-222

Parrilla I., Vazquez J.M., Cuello C., Gil M.A., Roca J., Di Berardino D., Martinez E.A. (2004)

Hoechst 33342 stain and u.v. laser exposure do not induce genotoxic effects in flowsorted boar spermatozoa.

Reproduction, 128, 615-621

Parrilla I., Vazquez J.M., Oliver-Bonet M., Navarro J., Yelamos J., Roca J., Martinez E.A. (2003)

Fluorescence in situ hybridization in diluted and flow cytometrically sorted boar spermatozoa using specific DNA direct probes labelled by nick translation.

Reproduction, 126, 317-325 
Parrish J.J., Foote R.H. (1986)

Fertility of cooled and frozen rabbit sperm measured by competitive fertilization. Biol Reprod, 35, 253-257

Parrish J.J., Susko-Parrish J.L., Graham J.K. (1999)

In vitro capacitation of bovine spermatozoa: role of intracellular calcium.

Theriogenology, 51, 461-472

Peknicova J., Moos J. (1990)

Monoclonal antibodies against boar acrosomal antigens labelling undamaged acrosomes of spermatozoa in immunofluorescence test.

Andrologia, 22, 427-435

Pena F.J., Johannisson A., Wallgren M., Rodriguez-Martinez H. (2003a)

Assessment of fresh and frozen-thawed boar semen using an Annexin-V assay: a new method of evaluating sperm membrane integrity.

Theriogenology, 60, 677-689

Pena F.J., Johannisson A., Wallgren M., Rodriguez-Martinez H. (2004a)

Effect of hyaluronan supplementation on boar sperm motility and membrane lipid architecture status after cryopreservation.

Theriogenology, 61, 63-70

Pena F.J., Johannisson A., Wallgren M., Rodriguez Martinez H. (2003b)

Antioxidant supplementation in vitro improves boar sperm motility and mitochondrial membrane potential after cryopreservation of different fractions of the ejaculate.

Anim Reprod Sci, 78, 85-98

Pena F.J., Johannisson A., Wallgren M., Rodriguez Martinez H. (2004b)

Antioxidant supplementation of boar spermatozoa from different fractions of the ejaculate improves cryopreservation: changes in sperm membrane lipid architecture. Zygote, 12, 117-124

Pena F.J., Johannisson A., Wallgren M., Rodriguez M.H. (2003c) Antioxidant supplementation in vitro improves boar sperm motility and mitochondrial membrane potential after cryopreservation of different fractions of the ejaculate.

Anim Reprod.Sci, 78, 85

Pena F.J., Saravia F., Johannisson A., Walgren M., Rodriguez-Martinez H. (2005)

A new and simple method to evaluate early membrane changes in frozen-thawed boar spermatozoa.

Int J Androl, 28, 107-114 
Perez L.J., Valcarcel A., De Las Heras M.A., Moses D., Baldassarre H. (1996)

Evidence that frozen/thawed ram spermatozoa show accelerated capacitation in vitro as assessed by chlortetracycline assay.

Theriogenology, $\underline{46}, 131$

Petrunkina A.M., Gehlhaar R., Drommer W., Waberski D., Töpfer-Petersen E. (2001)

Selective sperm binding to pig oviductal epithelium in vitro.

Reproduction, 121, 889-896

Petrunkina A.M., Harrison R.A., Petzoldt R., Weitze K.F., Töpfer-Petersen E. (2000)

Cyclical changes in sperm volume during in vitro incubation under capacitating conditions: a novel boar semen characteristic.

J Reprod Fertil, 118, 283-293

Pettitt M.J., Buhr M.M. (1998)

Extender components and surfactants affect boar sperm function and membrane behavior during cryopreservation.

J Androl, 19, 736-746

Pinkel D., Lake S., Gledhill B.L., Van Dilla M.A., Stephenson D., Watchmaker G. (1982)

High resolution DNA content measurements of mammalian sperm.

Cytometry, $\underline{3}, 1-9$

Pintado B., De La Fuente J., Roldan E.R. (2000)

Permeability of boar and bull spermatozoa to the nucleic acid stains propidium iodide or Hoechst 33258, or to eosin: accuracy in the assessment of cell viability. J Reprod Fertil, 118, 145-152

Polge C. (1956)

Artificial Insemination in Pigs.

Vet Rec, 62-76

Polge C., Salamon S., Wilmut I. (1970)

Fertilizing capacity of frozen boar semen following surgical insemination.

Vet Rec, 87, 424-429

Polge C., Smith A.U., Parkes A.S. (1949)

Revial of spermatozoa after vitrification and dehydration at low temperatures.

Nature, 164, 666

Popwell J.M., Flowers W.L. (2004)

Variability in relationships between semen quality and estimates of in vivo and in vitro fertility in boars.

Anim Reprod Sci, 81, 97-113 
Premzl B. (1985)

Deep freezing of boar semen in relation to changes on acrosome morphology at living sperms after thawing and the results of AI on 148 sows and 25 gilts. IN Johnson L.A. \& Larsson K. (Eds.) Deep freezing of boar semen. Uppsala, Sweden, Swedish University of Agricultural Sciences.

Premzl B., Vitkovic A., Herak M., Herak M. (1990)

Deep freezing of boar semen in $0.5 \mathrm{ml}$ straws. Boar semen preservation II. Beltsville, USA.

Probst S., Rath D. (2003)

Production of piglets using intracytoplasmic sperm injection (ICSI) with flowcytometrically sorted boar semen and artificially activated oocytes. Theriogenology, 59, 961-973

Pursel V.G., Johnson L.A. (1975a)

Freezing of boar spermatozoa: fertilizing capacity with concentrated semen and a new thawing procedure.

J Anim Sci, 40, 99-102

\section{Pursel V.G., Johnson L.A. (1975b)}

Freezing of boar spermatozoa: fertilizing capacity with concentrated semen and a new thawing procedure.

J Anim Sci JT - Journal of animal science., 40, 99

Rath D., Johnson L.A., Dobrinsky J.R., Welch G.R., Niemann H. (1997)

Production of piglets preselected for sex following in vitro fertilization with $\mathrm{X}$ and $\mathrm{Y}$ chromosome-bearing spermatozoa sorted by flow cytometry.

Theriogenology, 47, 795

Rath D., Johnson L.A., Görlach A. (1996)

Geschlecht von Kälbern jetzt vor der Besamung durch BSST vorausbestimmbar. Informationsblatt $d$ Tierzucht- $u$ Besamungstechniker, 120, 3-4

Rath D., Ruiz S., Sieg B. (2003a)

Birth of female piglets following intrauterine insemination of a sow using flow cytometrically sexed boar semen.

Vet Rec, 152, 400-401

Rath D., Sieg B., Leigh J., Klinc P., Besseling M., Krueger C., Wolken A., Frenzel A., et al. (2003b)

Current perspectives of sperm sorting in domestic farm animals. In: Proceedings of the 19th meeting Association Europenne de Transferet Embryonnaire. Rostock, Germany.

Raychoudhury S.S., Suarez S.S. (1991)

Porcine sperm binding to oviductual explants in culture.

Theriogenology, 36, 1059-1070 
Reed H.C.B. (1982)

Artificial Insemination.

In: Control of Pig Reproduction. London, Butterworth, 272-280

Rens W., Welch G.R., Johnson L.A. (1998)

A novel nozzle for more efficient sperm orientation to improve sorting efficiency of $\mathrm{X}$ and $\mathrm{Y}$ chromosome-bearing sperm.

Cytometry, 33, 476-481

Robertson L., Bailey J.L., Buhr M.M. (1990)

Effects of cold shock and phospholipase A2 on intact boar spermatozoa and sperm head plasma membranes.

Mol Reprod Dev, 26, 143-149

Roca J., Carvajal G., Lucas X., Vazquez J.M., Martinez E.A. (2003)

Fertility of weaned sows after deep intrauterine insemination with a reduced number of frozen-thawed spermatozoa.

Theriogenology, 60, 77-87

Roca J., Gil M.A., Hernandez M., Parrilla I., Vazquez J.M., Martinez E.A. (2004)

Survival and fertility of boar spermatozoa after freeze-thawing in extender supplemented with butylated hydroxytoluene.

J Androl, 25, 397-405

Roca J., Hernandez M., Carvajal G., Vazquez J.M., Martinez E.A. (2006a) Factors influencing boar sperm cryosurvival.

J Anim Sci, 4, 2692-2699

Roca J., Rodriguez-Martinez H., Vazquez J.M., Bolarin A., Hernandez M., Saravia F., Wallgren M., Martinez E.A. (2006b)

Strategies to improve the fertility of frozen-thawed boar semen for artificial insemination.

Reprod Suppl, 62, 261-275

Roca J., Rodriguez M.J., Gil M.A., Carvajal G., Garcia E.M., Cuello C., Vazquez J.M., Martinez E.A. (2005a)

Survival and in vitro fertility of boar spermatozoa frozen in the presence of superoxide dismutase and/or catalase.

J Androl JT - Journal of andrology., 26, 15

Roca J., Rodriguez M.J., Gil M.A., Carvajal G., Garcia E.M., Cuello C., Vazquez J.M., Martinez E.A. (2005b)

Survival and in vitro fertility of boar spermatozoa frozen in the presence of superoxide dismutase and/or catalase.

J Androl, 26, 15-24 
Rodriguez-Martinez H., Eriksson B., Lundeheim N. (1996)

Freezing boar semen in flat plastic bags membrane integrity and fertility. Boar semen preservation III. Mariensee, Germany.

Reprod. Dom. Anim., Suppl 1

Rohloff D. (1967)

Tiefgefrierung von Ebersperma in pelletform bei $-196^{\circ} \mathrm{C}$.

Zuchthyg, 2, 75-77

Roosen-Runge E.C. (1962)

The process of spermatogenesis in mammals.

Biol Rev Camb Philos Soc, 37, 343-377

Rozeboom K.J., Troedsson M.H., Molitor T.W., Crabo B.G. (1999)

The effect of spermatozoa and seminal plasma on leukocyte migration into the uterus of gilts.

J Anim Sci, 77, 2201-2206

Sakkas D., Manicardi G., Bianchi P.G., Bizzaro D., Bianchi U. (1995)

Relationship between the presence of endogenous nicks and sperm chromatin packaging in maturing and fertilizing mouse spermatozoa.

Biol Reprod, 52, 1149-1155

Sakkas D., Manicardi G.C., Bizzaro D. (2003)

Sperm nuclear DNA damage in the human.

Adv Exp Med Biol, 518, 73-84

Salamon S., Maxwell W.M.C. (1995)

Frozen storage of ram semen II. Causes of low fertility after cervical insemination and methods of improvement.

Anim. Reprod. Sci., 38, 1

Saling P.M., Storey B.T. (1979)

Mouse gamete interactions during fertilization in vitro. Chlortetracycline as a fluorescent probe for the mouse sperm acrosome reaction.

J Cell Biol, $\underline{83}$, 544-555

Samoulidis S., Saoulidis K., Kuriakis S., Giannakopoulos K., Tsakalof P., Kyriakis S.C. (1996)

New modified method for extending and freezing boar semen.

Deltion tes Ellenikes Kteniatrikes Etaireias = Bulletin of the Hellenic Veterinary

Medical Society, 47, 275-279

Sanchez-Partida L.G., Setchell B.P., Maxwell W.M. (1997)

Epididymal compounds and antioxidants in diluents for the frozen storage of ram spermatozoa.

Reprod Fertil Dev, 9, 689-696 


\section{Saravia F., Wallgren M., Nagy S., Johannisson A., Rodriguez-Martinez H.} (2005)

Deep freezing of concentrated boar semen for intra-uterine insemination: effects on sperm viability.

Theriogenology, 63, 1320-1333

Schrader R. (1976)

Untersuchungen zur Tiefgefrierkonservierung von Ebersamen.

Tierärztl. Hochschule, Diss., Hannover

Schrader S.M., Platek S.F., Zaneveld L.J., Perez-Pelaez M., Jeyendran R.S. (1986)

Sperm viability: a comparison of analytical methods.

Andrologia, 18, 530-538

Seidel G.E., Jr. (2003)

Sexing mammalian sperm--intertwining of commerce, technology, and biology.

Anim Reprod Sci, 79, 145-156

Seidel G.E., Jr., Garner D.L. (2002)

Current status of sexing mammalian spermatozoa.

Reproduction, 124, 733-743

Seidel G.E., Jr., Schenk J.L., Herickhoff L.A., Doyle S.P., Brink Z., Green R.D., Cran D.G. (1999)

Insemination of heifers with sexed sperm.

Theriogenology, 52, 1407-1420

Selles E., Gadea J., Romar R., Matas C., Ruiz S. (2003)

Analysis of in vitro fertilizing capacity to evaluate the freezing procedures of boar semen and to predict the subsequent fertility.

Reprod Dom. Anim, 38, 66-72

Selles E., Wallgren M., Gadea J., Rodriguez Martinez H. (2001)

Sperm viability and capacitation-like changes in fractions of boar semen after storage and freezing. Proceedings of the VIth International Conference on Pig Reproduction. Columbia, MO, USA.

Serrano H., Diaz-Esparza L., Garcia-Suarez D. (2001)

Pig sperm membrane integrity evaluated by lectin labeling.

Arch Androl, 47, 59-65

Shannon P., Curson B. (1972)

Toxic effect and action of dead sperm on diluted bovine semen.

J Dairy Sci, 55, 614-620 
Shekarriz M., Dewire D.M., Thomas A.J., Jr., Agarwal A. (1995)

A method of human semen centrifugation to minimize the iatrogenic sperm injuries caused by reactive oxygen species.

Eur.Urol., 28, 31

Shen H.M., Chia S.E., Ong C.N. (1999)

Evaluation of oxidative DNA damage in human sperm and its association with male infertility.

J Androl, 20, 718-723

Simmet C. (1993)

Cryophysical aspects of the freezing of boar semen and the effects of freezing on semen quality and conception rate.

Dissertation, Tierärztl. Hochschule Hannover, Hannover

Simpson A.M., White I.G. (1986)

Effect of cold shock and cooling rate on calcium uptake of ram spermatozoa.

Animal Reproduction Science, 12, 131

Sinowatz F., Vogelmayr J.K., Gabius H.-J., Friess A.E. (1989)

Cytochemical analysis of mammalian sperm membranes.

Progress in Histochemistry and Cytohistochemistry, 19

Sklar L.A., Miljanich G.P., Dratz E.A. (1979)

Phospholipid lateral phase separation and the partition of cis-parinaric acid and transparinaric acid among aqueous, solid lipid, and fluid lipid phases.

Biochemistry, 18, 1707-1716

Soares J.A.G. (1995)

Befruchtungsergebnisse beim Schwein nach transzervikaler Applikation von

Seminalplasma unmittelbar vor der Insemination.

Tierärztl. Hochschule, Diss, Hannover

Soede N.M., Bouwman E.G., Kemp B. (1998)

Seminal plasma does not advance ovulation in hCG-treated sows.

Anim Reprod Sci, 54, 23-29

Sommer J.R., Collins E.B., Neiding T., Rozeboom K., Wong F., Petters R.M. (2002)

Conservation and regeneration of transgenic lines of swine by semen cryopreservation and artificial insemination.

Lab Anim.l, 31, 25-31

Sotolongo B., Huang T.T., Isenberger E., Ward W.S. (2005)

An endogenous nuclease in hamster, mouse, and human spermatozoa cleaves DNA into loop-sized fragments.

J Androl, 26, 272-280 
Spallanzani L. (1776)

Opuscoli di fisca animale e vegetabile. Obuscolo II. Observazioni e esperenze intorno ai vermicelli spermatici dell' homo e degli animali. (Observations upon the spermatozoa of humans and animals).

Modena. Cited by Watson PF: 1979,

Stahlberg R., Harlizius B., Weitze K.F., Waberski D. (2000)

Identification of embryo paternity using polymorphic DNA markers to assess fertilizing capacity of spermatozoa after heterospermic insemination in boars. Theriogenology, 53, 1365-1373

Stampa E. (1989)

Befruchtungsfähigkeit von tiefgefrorenem Ebersperma; Einfluss von Konfektionierung, Besamungshäufigkeit und Seminalplasma.

Thesis, Tierärztliche Hochschule, Tierärztliche Hochschule, Hannover

Stanek R., Veselsky L., Dostal J., Sedlakova E. (1985)

Effect of boar seminal plasma and seminal vesicle fluid on porcine lymphocytes. Arch Androl, 15, 29-32

Steverink D.W., Soede N.M., Groenland G.J., Van Schie F.W., Noordhuizen J.P., Kemp B. (1999)

Duration of estrus in relation to reproduction results in pigs on commercial farms. J Anim Sci, 77, 801-809

Stewart D.L. (1951)

Storage of bull spermatozoa at low temperatures.

Vet Rec, $\underline{63}$, 65-66

Strom B., Rota A., Linde-Forsberg C. (1997)

In vitro characteristics of canine spermatozoa subjected to two methods of cryopreservation.

Theriogenology, 48, 247-254

Suarez S., Redfern K., Raynor P., Martin F., Phillips D.M. (1991)

Attachment of boar sperm to mucosal explants of oviduct in vitro: possible role in formation of a sperm reservoir.

Biol Reprod, 44, 998-1004

Suarez S.S., Varosi S.M., Dai X. (1993)

Intracellular calcium increases with hyperactivation in intact, moving hamster sperm and oscillates with the flagellar beat cycle.

Proc Natl Acad Sci U S A, 90, 4660-4664

Suh T.K., Schenk J.L. (2003)

Pressure during flow sorting of bull sperm affects post-thaw motility characteristics. Theriogenology, 59, 516 
Szasz F., Sirivaidyapong S., Cheng F.P., Voorhout W.F., Marks A., Colenbrander B., Solti and L., Gadella B.M. (2000)

Detection of calcium ionophore induced membrane changes in dog sperm as a simple method to predict the cryopreservability of dog semen.

Mol Reprod Dev, 55, 289-298

Takacs T., Machaty Z., Matyus L., Damjanovich S. (1990)

Effect of PGF2-alpha supplementation on fertilizing capacity of frozen boar semen; Viability evaluation of frozen semen according to membrane potential. Boar semen preservation II.

Reprod. Dom Anim., Suppl. 1

Taylor U., Rath D., Zerbe H., Schuberth H.J. (2007)

Interaction of intact porcine spermatozoa with epithelial cells and neutrophilic granulocytes during uterine passage.

Reprod. Dom Anim., in press

Thilmant P. (1999)

Cryopreservation of boar semen: field results in Belgium during 1995 and 1996. Journees de la Recherche Porcine en France, 31, 59-64

Thilmant P. (2001)

Cryopreservation of boar semen in $0.25 \mathrm{ml}$ (mini) French straws. Field results. Journees de la Recherche Porcine en France, 33, 151-156

Thomas C.A., Garner D.L., Dejarnette J.M., Marshall C.E. (1997)

Fluorometric assessments of acrosomal integrity and viability in cryopreserved bovine spermatozoa.

Biol Reprod, 56, 991-998

Thomas C.A., Garner D.L., Dejarnette J.M., Marshall C.E. (1998)

Effect of cryopreservation of bovine sperm organelle function and viability as determined by flow cytometry.

Biol.Reprod., 58, 786

Töpfer-Petersen E., Auerbeck J., Weiss A., Friess A.E., Schill W.B. (1986)

The sperm acrosome: immunological analysis using specific polyclonal and monoclonal antibodies directed against the outer acrosomal membrane of boar spermatozoa.

Andrologia, 18, 237-251

Töpfer-Petersen E., Aurich C. (2000)

Reproduktion beim männlichen Tier.

IN: Engelhard W. \& Breves G. (Eds.) Physiologie der Haustiere. Stuttgart, Verlag

Ferdinand Encke, 537-555

Töpfer-Petersen E., Calvete J.J., Dostalova Z., Reinert M., Waberski D., Sanz L., Hübner T. (1995a)

One year in the life of the spermadhesin family.

Fertilität, 11, 233-241 
Töpfer-Petersen E., Calvete J.J., Sanz L., Sinowatz F. (1995b)

Carbohydrate-and heparin-binding proteins in mammalian fertilization.

Andrologia, 27, 303-324

Töpfer-Petersen E., Ensslin M., Waberski D. (1996)

Kapazitation.

Fertilität, 12, 183-189

Töpfer-Petersen E., Friess A.E., Schill W.B. (1988)

The acrosome reaction in boar spermatozoa.

Hum Reprod, 3 , 319-326

Töpfer-Petersen E., Friess A.E., Sinowatz F., Biltz S., Schill W.B. (1985)

Immunocytological characterization of the outer acrosomal membrane (OAM)

during acrosome reaction in boar.

Histochemistry, $\underline{82,113-120}$

Töpfer-Petersen E., Friess A.E., Stoffel M., Schill W.B. (1990)

Boar sperm membranes antigens. I. Topography of a mobile glycoprotein of the sperm cell membrane.

Histochemistry, 93, 485-490

Töpfer-Petersen E., Januschke E., Schmoeckel C., Schill W.B. (1984)

Ultrastructural localization of lectin binding sites of the acrosomal membrane system of boar spermatozoa.

Andrologia, 16, 538-547

Töpfer-Petersen E., Schill W.-B. (1989)

The sperm surface and sperm-egg interaction in the pig.

IN: Holstein A.F., Voigt K.D. \& Grässlin D. (Eds.) In: Reproductive Biology and Medicine. Berlin, Diesbach, 78-90

Töpfer-Petersen E., Waberski D., Hess O., Bellair S., Schambony A., EkhlasiHundrieser M., Gentzel M., Reineke A. (1998)

Bedeutung des Seminalplasmas für die Befruchtung.

Tierärztl Umschau, 53, 447-454

Tosic J. (1947)

Mechanism of hydrogen peroxide formation by spermatozoa and the role of aminoacids in sperm motility.

Nature, $\underline{159}, 544$

Troedsson M.H.T., Crabo B.G., Scott M., Ing M. (1995)

Mating-induced endometritis (MIE): Mechanism, clinical importance and consequences.

Proc Am Assoc Eq Pract, 41, 11-12 
Trotter J. (1998)

WinMDI 2.8. Version 2.8 ed.

http://facs.scripps.edu/software.html, downloaded: 3.4.2005

Upreti G.C., Jensen K., Munday R., Duganzich D.M., Vishwanath R., Smith J.F. (1998)

Studies on aromatic amino acid oxidase activity in ram spermatozoa: role of pyruvate as an antioxidant.

Anim Reprod.Sci, 51, 275

Upreti G.C., Jensen K., Oliver J.E., Duganzich D.M., Munday R., Smith J.F. (1997)

Motility of ram spermatozoa during storage in a chemically-defined diluent containing antioxidants.

Anim Reprod Sci, 48, 269-278

Vazquez J.L., Martinez E.A., Vazquez J.M., Lucas M., Gil M.A., Parilla I., Al. E. (1999)

Development of a non-surgical deep insemination technique. Proceedings of the IV International Conference on Boar Semen Preservation. Beltsville, Maryland Reprod. Dom. Anim., Suppl. 1

Vazquez J.M., Martinez E., Roca J., Matas C., Blanco O. (1998)

The fertilizing ability assessment of fresh and stored boar semen.

Reprod Dom. Anim, 33, 267-270

Vazquez J.M., Martinez E.A., Martinez P., Garcia-Artiga C., Roca J. (1997)

Hypoosmotic swelling of boar spermatozoa compared to other methods for analysing the sperm membrane.

Theriogenology, 47, 913

Viring S., Einarsson S. (1980)

Influence of boar seminal plasma on the distribution of spermatozoa in the genital tract of gilts.

Acta Vet Scand, 21, 598-606

Visconti P.E., Galantino-Homer H., Moore G.D., Bailey J.L., Ning X., Fornes M., Kopf G.S. (1998)

The molecular basis of sperm capacitation.

J Androl, 19, 242-248

Waberski D., Claassen R., Hahn T., Jungblut P.W., Parvizi N., Kallweit E., Weitze K.F. (1997)

LH profile and advancement of ovulation after transcervical infusion of seminal plasma at different stages of oestrus in gilts.

J Reprod Fertil, 109, 29-34 
Waberski D., Magnus F., Ardon F., Petrunkina A.M., Weitze K.F., Töpfer-

Petersen E. (2006)

Binding of boar spermatozoa to oviductal epithelium in vitro in relation to sperm morphology and storage time.

Reproduction, 131, 311-318

Waberski D., Magnus F., Ferreira F.M., Petrunkina A.M., Weitze K.F., TöpferPetersen E. (2005)

Importance of sperm-binding assays for fertility prognosis of porcine spermatozoa. Theriogenology, $\underline{63}, 470$

Waberski D., Petrunkina A.M., Weitze K.F., Töpfer-Petersen E. (1999) In vitro assessment of semen for the prediction of fertility.

Tierarztl Prax Ausg G Grosstiere Nutztiere, 27, 1-7

Waberski D., Soares J.A.G., Bandeira D.E., Arruda E., Weitze K.F. (1996)

Effect of transcervical infusion of seminal plasma prior to insemination on the fertilizing competence of low numbers of boar spermatozoa at controlled AIovulation intervals.

Anim Reprod Sci, 44, 165-173

Wagner H.G., Thibier M. (2000)

World statistic for artificial insemination in small ruminants and swine.

14th International Congress on Animal Reproduction. Stockholm, 77

Wang A., Fanning L., Anderson D.J., Loughlin K.R. (1997)

Generation of reactive oxygen species by leukocytes and sperm following exposure to urogenital tract infection.

Arch.Androl, 39, 11

Ward C.R., Storey B.T. (1984)

Determination of the time course of capacitation in mouse spermatozoa using a chlortetracycline fluorescence assay.

Dev Biol, 104, 287-296

Ward M.A., Ward W.S. (2004)

A model for the function of sperm DNA degradation.

Reprod Fertil Dev, 16, 547-554

Watson P.F. (1995)

Recent developments and concepts in the cryopreservation of spermatozoa and the assessment of their post-thawing function.

Reprod Fertil Dev, 7, 871-891

Watson P.F. (2000)

The causes of reduced fertility with cryopreserved semen.

Anim Reprod Sci, 60-61, 481-492 
Wehner R., Gehring W. (1990)

Zoologie.

Stuttgart, New York, Georg Thiehme Verlag, 177-443

Weitze K.F. (2000)

Update on the worldwide application of swine AI.

Boar Semen Preservation IV. Beltsville, 141-145

Reprod. Dom. Anim., Suppl. 1

Weitze K.F., Lotz J.H., Everwand A., Willmen T., Waberski D. (1990a)

Interaction between inseminate, uterine and ovarial function in the sow II:

Investigations into the influencing of ovulation by the use of sperm-free media.

Reprod Dom. Anim, 25, 197-204

Weitze K.F., Stampa E., Richter L. (1990b)

Fertility of frozen boar semen: Influence of packaging, number of inseminations, and seminal plasma. Boar semen preservation II. Beltsville, USA.

Welch G., Waldbieser G.C., Wall R.J., Johnson L.A. (1995)

Flow cytometric sperm sorting and PCR to confirm separation of X- and Y-

chromosme bearing bovine sperm.

Animal Biotechnology, 6, 131-139

Welch G.R., Johnson L.A. (1999)

Sex preselection: laboratory validation of the sperm sex ratio of flow sorted $\mathrm{X}$ - and Y-sperm by sort reanalysis for DNA.

Theriogenology, 52, 1343-1352

Wells M.E., Awa O.A. (1970)

New technique for assessing acrosomal characteristics of spermatozoa.

J Dairy Sci, 53, 227-232

Westendorf P., Richter L., Treu H. (1975)

[Deep freezing of boar sperma. Laboratory and insemination results using the Hulsenberger paillete method].

Dtsch Tierarztl Wochenschr, $\underline{\text { 82, 261-267 }}$

White I.G. (1993)

Lipids and calcium uptake of sperm in relation to cold shock and preservation: a review.

Reprod Fertil Dev, 5, 639-658

Whittington K., Ford W.C. (1998)

The effect of incubation periods under $95 \%$ oxygen on the stimulated acrosome reaction and motility of human spermatozoa.

Mol.Hum.Reprod., 4, 1053 
Williamson P., Mattocks K., Schlegel R.A. (1983)

Merocyanine 540, a fluorescent probe sensitive to lipid packing.

Biochim Biophys Acta, 732, 387-393

Wilmut I., Polge C. (1977)

The low temperature preservation of boar spermatozoa. 3. The fertilizing capacity of frozen and thawed boar semen.

Cryobiology, 14, 483-491

\section{Woelders H. (1991)}

Overview of in vitro methods for evaluation of semen quality.

IN: Johnson L.A. \& Rath D. (Eds.) Boar semen preservation II. Berlin and Hamburg, Paul Parey Scientific Publishers, 145-164

Reprod. Dom. Anim., Suppl. 1

Woelders H., Matthijs A., Zuidberg C.A., Chaveiro A.E. (2005)

Cryopreservation of boar semen: equilibrium freezing in the cryomicroscope and in straws.

Theriogenology, $\underline{63}, 383-395$

\section{Wongtawan T., Saravia F., Wallgren M., Caballero I., Rodriguez-Martinez H.} (2006)

Fertility after deep intra-uterine artificial insemination of concentrated low-volume boar semen doses.

Theriogenology, $\underline{65}$, 773-787

Würgau T. (1986)

Zur Bedeutung der tertären Anomalien für die Beurteilung der

Spermienmorphologie.

Dissertation, Fakultät für Veterinärmedizin, Ludwig-Maximilians Universität,

München

Xu D.X., Wu S.J. (1990)

The freezing technique for boar semen. Boar semen preservation II. Beltsville, USA. Reprod. Dom. Anim., Suppl. 1

Xu X., Ding J., Seth P.C., Harbison D.S., Foxcroft G.R. (1996)

In vitro fertilization of in vitro matured pig oocytes: Effects of boar and ejaculate fraction.

Theriogenology, $\underline{45}$, 745-755

Yanagimachi R. (1994)

Mammalian fertilization.

IN: Knobil E. \& Neill J.D. (Eds.) The physiology of reproduction.

New York, Raven Press, 189-317 
Yi Y.J., Cheon Y.M., Park C.S. (2002a)

Effect of N-acetyl-D-glucosamine, and glycerol concentration and equilibration time on acrosome morphology and motility of frozen-thawed boar sperm.

Anim Reprod Sci, 69, 91-97

Yi Y.J., Im G.S., Park C.S. (2002b)

Lactose-egg yolk diluent supplemented with N-acetyl-D-glucosamine affect acrosome morphology and motility of frozen-thawed boar sperm.

Anim Reprod Sci, 74, 187-194

Yoshida M. (2000)

Conservation of sperms: current status and new trends.

Anim Reprod Sci, 60-61, 349-355

Zeng W., Terada T. (2000)

Freezability of boar spermatozoa is improved by exposure to 2-hydroxypropyl-betacyclodextrin.

Reprod Fertil Dev, 12, 223-228

Zeng W.X., Shimada M., Isobe N., Terada T. (2001)

Survival of boar spermatozoa frozen in diluents of varying osmolality.

Theriogenology, 56, 447-458

Zeng W.X., Terada T. (2001)

Effects of methyl-beta-cyclodextrin on cryosurvival of boar spermatozoa.

J Androl, 22, 111-118

Zhang J., Boyle M.S., Smith C.A., Moore H.D. (1990)

Acrosome reaction of stallion spermatozoa evaluated with monoclonal antibody and zona-free hamster eggs.

Mol Reprod Dev, 27, 152-158

Zheng Y.S., Fiser P., Sirard M.A. (1992)

The use of ejaculated boar semen after freezing in 2 or $6 \%$ glucerol for in vitro fertilization of porcine oocytes matured in vitro.

Theriogenology, $\underline{38,1065-1075}$ 


\section{List of Tables}

Table 1: Recent reports about improving methods for cryo-preservation of boar semen

Table 2: $\quad$ Summary of fertility results with frozen/thawed boar semen, 19852007

Table 3: Antioxidants that have been used to improve the quality of frozen/thawed spermatozoa in different species

Table 4: Test to monitorchanges in sperm membranes, organelles, DNA, and functionality applicable to boar semen

Table 5: Overview on parameters used or predicted to separate $\mathrm{X}$ and $\mathrm{Y}$ chromosome bearing spermatozoa 66

Table 6: Protocol of three different freezing curves 78

Table 7: Different thawing protocols for boar semen according to freezing methods

Table 8: Percentage of motile spermatozoa exposed to a $6 \mathrm{~h}$ thermo resistance test after thawing employing different antioxidants in the cooling and freezing extenders

Table 9: Percentage of morphologically abnormal spermatozoa directly after thawing.

Table 10: Results of the flowcytometrical evaluation of membrane integrity and acrosome reaction of frozen/thawed spermatozoa applying SYTO-17/FITC-PNA/PI $0 \mathrm{~h}$ and $2 \mathrm{~h}$ after thawing

Table 11: Motility of fresh semen samples directly after collection and dilution and after cooling to $15^{\circ} \mathrm{C}$ as analyzed with CASA 
Table 12: Percentage of morphologically abnormal spermatozoa after Glutaraldehyd fixation (6 ejaculates from 4 four boars each) - Fresh semen samples

Table 13: Sperm motility of Boar A in a thermo-resistance-test of spermatozoa frozen and thawed according to one of three different freezing protocols. 84

Table 14: Sperm motility of Boar B in a thermo-resistance-test of spermatozoa frozen and thawed according to three different freezing curves

Table 15: Sperm motility of Boar C during a thermo-resistance-test of spermatozoa frozen and thawed according to three different freezing curves

Table 16: Sperm motility of Boar D in a thermo-resistance-test of spermatozoa frozen and thawed according to three different freezing curves 86

Table 17: Mean motility of all boars during the thermo resistances test in the percentage of motile spermatozoa between samples frozen in either one of the respective freezing protocols 86

Table 18: Percentage of morphological abnormal spermatozoa of Boar A directly after thawing

Table 19: Percentage of morphologically abnormal spermatozoa of Boar B directly after thawing.

Table 20: Percentage of morphologically abnormal spermatozoa of Boar C directly after thawing..... 88

Table 21: Percentage of morphologically abnormal spermatozoa of Boar D directly after thawing.....

Table 22: Percentage of morphologically abnormal spermatozoa of all boars directly after thawing..... 
Table 23: Flow cytometrical evaluation of Boar A sperm membrane integrity and acrosome reaction of frozen/thawed spermatozoa applying SYTO-17/FITC-PNA/PI $0 \mathrm{~h}$ and $2 \mathrm{~h}$ after thawing 90

Table 24: Flow cytometrical evaluation of Boar B sperm membrane integrity and acrosome reaction of frozen/thawed spermatozoa applying SYTO-17/FITC-PNA/PI $0 \mathrm{~h}$ and $2 \mathrm{~h}$ after thawing 91

Table 25: Flow cytometrical evaluation of Boar C sperm membrane integrity and acrosome reaction of frozen/thawed spermatozoa applying SYTO-17/FITC-PNA/PI $0 \mathrm{~h}$ and $2 \mathrm{~h}$ after thawing....

Table 26: Flow cytometrical evaluation of Boar D sperm membrane integrity and acrosome reaction of frozen/thawed spermatozoa applying SYTO-17/FITC-PNA/PI $0 \mathrm{~h}$ and $2 \mathrm{~h}$ after thawing.... 93

Table 27: Flow cytometrical evaluation of sperm membrane integrity and acrosome reaction of frozen/thawed spermatozoa applying SYTO17/FITC-PNA/PI $0 \mathrm{~h}$ and $2 \mathrm{~h}$ after thawing for all boars

Table 28: Treatment groups for cryo-preservation of sex-sorted semen 103

Table 29: Sperm motility of fresh and sex-sorted samples after 0, 24 and 120 hours of storage at $15^{\circ} \mathrm{C}$ and subsequent incubation at $38^{\circ} \mathrm{C}$ extended in Androhep ${ }^{\mathrm{TM}}$ containing different antioxidants or no additives.

Table 30: Results of the morphological evaluation of the semen samples after 120 hof storage at $15^{\circ} \mathrm{C}$

Table 31: Results of the flow cytometrical evaluation of membrane integrity and acrosome reaction of fresh spermatozoa applying SYTO17/FITC-PNA/PI staining 108

Table 32: Percentage of motile spermatozoa after thawing and dilution in AndrohepTM at 0, 1, 2, 3 and 6 hours after thawing.... 109 
Table 33: Results of the morphological evaluation of the spermatozoa after freezing and thawing 110

Table 34: Results of flow cytometrical evaluation of membrane integrity and acrosome reaction of frozen/thawed spermatozoa applying SYTO17/FITC-PNA/PI 0h, 3h and 6h after thawing (values are displayed as $\overline{\mathrm{X}} \pm \mathrm{SD})$ 


\section{List of Figures}

Figure 1: $\quad$ Spermatozoa (Garner and Hafez 2000).................................................. 4

Figure 2: Principle of a flowcytometer for sex sorting mammalian spermatozoa (modified Rath et al. 1996) 


\section{DECLARATIONS}

1. I, hereby, declare that this Ph.D. dissertation has not been presented to any other examining body either in its present or a similar form.

Furthermore, I also affirm that I have not applied for a Ph.D. at any other higher school of education.

Göttingen, 26. May 2007

\section{Rudolf Großfeld}

2. I, hereby, solemnly declare that this dissertation was undertaken independently and without any unauthorised aid.

Göttingen, 26. May 2007

Rudolf Großfeld 


\section{$\underline{\text { Acknowledgments }}$}

I would like to thank Prof. Dr. Holtz for the support of this work and the always friendly help and advice.

I am most grateful to Prof. Dr. Detlef Rath for his consistent professional and personal advice, that was available whenever and wherever I needed it. Thank you very much for this ongoing support during the whole work, that was given in a very kind and always reliable way. Without this help I would never have learned so much.

I am grateful to the "Gesellschaft der Freunde der FAL" and especially Minitüb Abfüll- und Labortechnik for the financial support of this work.

I am also grateful to Prof. Chis Maxwell for such a good support during my time in Australia. Your professional help and hospitality made this stay a great experience in every kind of way. I would to thank Prof. Gareth Evans and Prof. Chris Moran for their support.

I am very grateful to Dr. Heinzemann, Brigitta Lunderstädt and Romy Voss from the International PhD-Program for Agricultural Sciences in Göttingen for a great support and offered possibilities that always exceed my expectations. Thank you, you did a really great job!

I am very grateful to Birgit Sieg for her always friendly support during my trials, the great encouragement and enduring commitment with the flowcytometer despite all obstacles.

This also counts for Christina Struckmann and Antje Frenzel who as well encouraged me during my work and also where great in the battle with the flowcytometer and everything else.

I would to especially thank Klaus-Gerd Hadeler and Rolf Poppenga for such a exceptionally and friendly helpfulness during my time in Mariensee.

I would to thank Dr. Christine Ehling and Lothar Schindler for introducing me into the subject and for all the discussions and support.

I also would like to thank everyone else in Mariensee for all the help I got, for the discussions, for the encouragements and for being such good colleagues and peers. This also counts for all colleagues during my stay at the USYD. Thank you very much for all the support and help to make my stay a great experience. That especially counts for Roslyn, Shelley and Simon. 